U.S. Department of the Interior

U.S. Geological Survey

\title{
Water-Resources Investigations in Wisconsin, 2002
}

Open-File Report 02-300
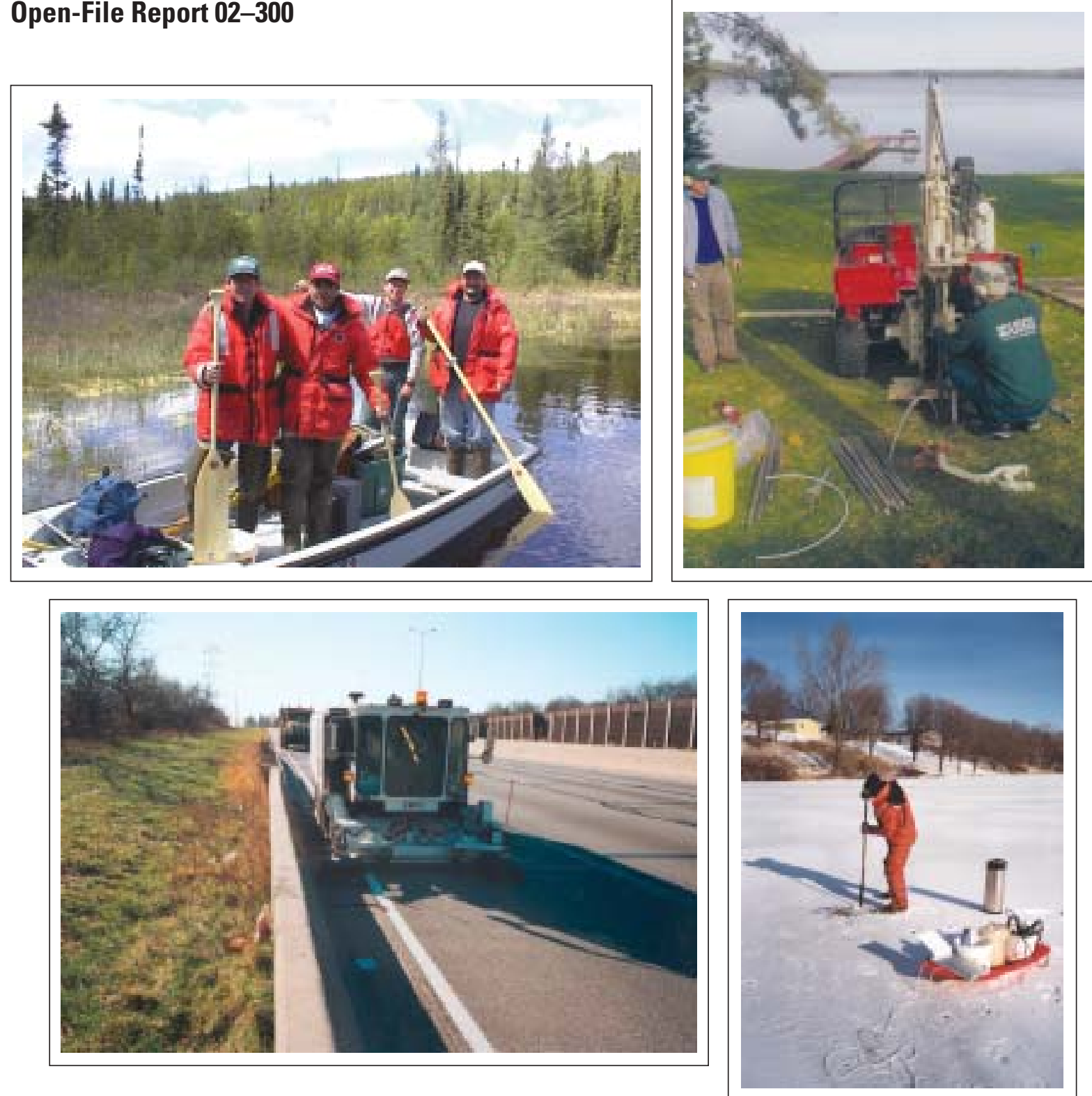


\section{WATER-RESOURCES INVESTIGATIONS IN WISCONSIN, 2002}

\section{Compiled by K.A. Hueschen, S.Z. Jones, and J.A. Fuller}

U.S. GEOLOGICAL SURVEY

Open-File Report 02-300

Middleton, Wisconsin

2002

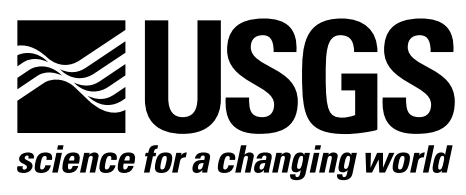




\section{U.S. DEPARTMENT OF THE INTERIOR \\ Gale A. Norton, Secretary}

U.S. GEOLOGICAL SURVEY

Charles G. Groat, Director

The use of firm, trade, and brand names in this report is for identification purposes only and does not constitute endorsement by the U.S. Government.

For additional information write to:

District Chief

U.S. Geological Survey

8505 Research Way

Middleton, WI 53562-3586
Copies of this report can be purchased from:

U.S. Geological Survey

Branch of Information Services

Box 25286

Denver, CO 80225-0286 


\section{CONTENTS}

\section{Introduction}

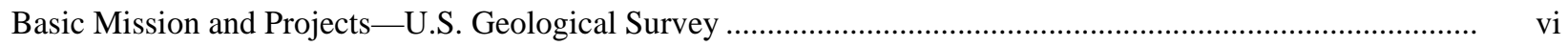

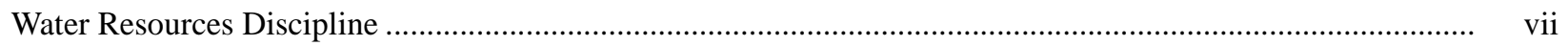

Graph showing funding sources for the water-resources program in Wisconsin for the 2002 fiscal year ............ vii

Organization chart of the U.S. Geological Survey, Water Resources Discipline, Wisconsin District.................. viii

Map showing location of offices in the Wisconsin District ........................................................................ ix

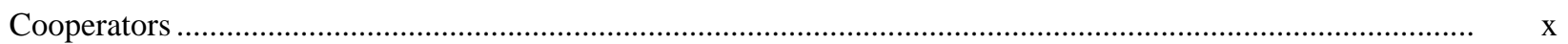

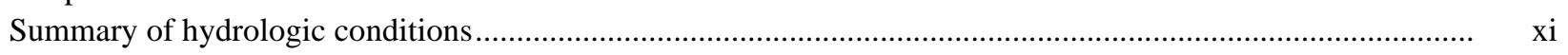

Map showing 2001 runoff as percentage of long-term runoff ...................................................................

\section{Teams}

Basic Records and Monitoring Team

Collection of basic records-surface water, WI 00100

Collection of basic records-ground water, WI 00200.

Collection of basic records-Dane County Program, WI 00302.

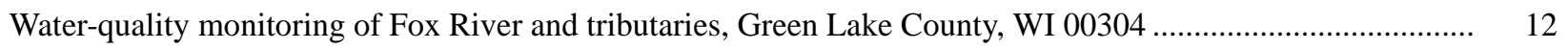

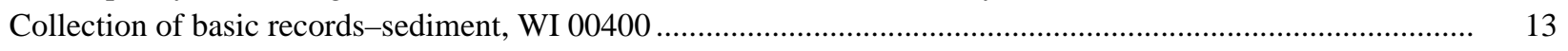

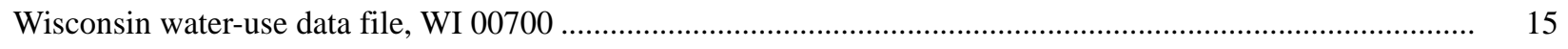

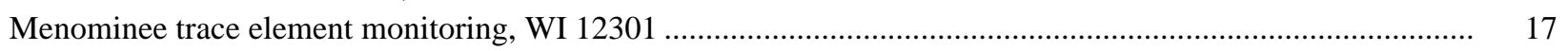

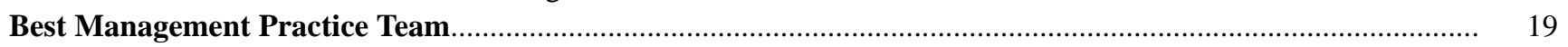

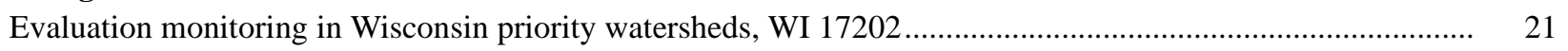

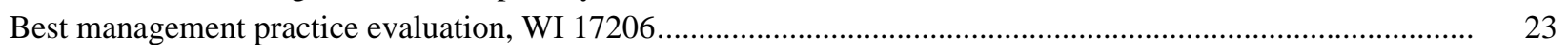

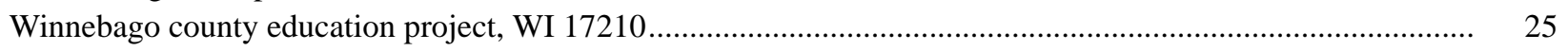

Influences of riparian corridors on the in-stream habitat, fish, and macroinvertebrate communities for

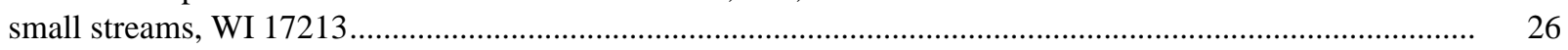

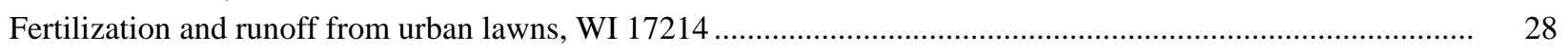

Impact of phosphorus and nitrogen concentrations on the biological integrity of Wisconsin streams, WI 17223

Hydrology and water-quality impacts of different pasture management practices in southwestern

Wisconsin, WI $17229 .$.

Discovery Farms, WI 17239

Quantification of constituent loads from farm fields at the Pioneer Farms in Wisconsin, WI 17240 ................. 36

Ground-Water Systems Team .....

Crandon ground water, WI 00201

Simulation of shallow-groundwater flow on the Stockbridge Munsee Indian Reservation with the use of an analytic element model, WI 12307 .

Characterization of the regional aquifer flow-system on the Menominee Indian Reservation, WI 12312 ...........

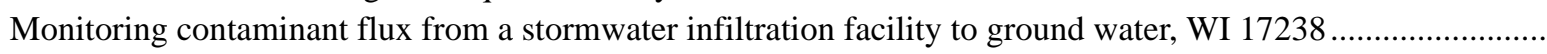

Pool 8 ground-water/surface-water study, WI 17304

Hydrologic investigation of Silver Lake, WI 17305.

Southeast Wisconsin ground water, WI 20800

Regional hydrogeologic study of La Crosse County, Wisconsin, WI 21900.

Susceptibility of La Crosse municipal wells to enteric virus contamination from surface water contribution, WI 21901

Regional hydrogeologic study of Sauk County, Wisconsin, WI 22000...

Menomonee valley ground-water model, WI 22400 


\section{CONTENTS-Continued}

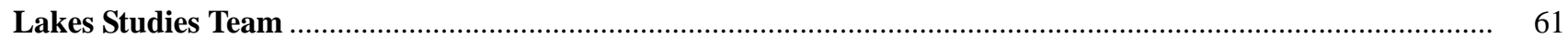

Lake water-quality monitoring, chemical and biological monitoring of selected lakes, WI 13300................... 63

Assessment of the hydrology and water quality of, and phosphorus loading to, Pike Lake in Washington

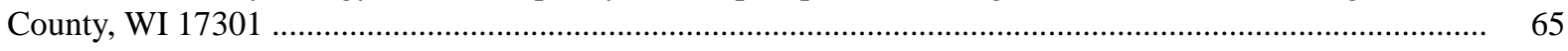

Miscellaneous monitoring associated with lakes, WI 17302 _........................................................................ 67

Wisconsin Lakes, Green Lake tributary monitoring, WI 17303 ................................................................... 68

Assessment of the hydrology, water quality, and phosphorus loading of Muskellunge Lake, Vilas

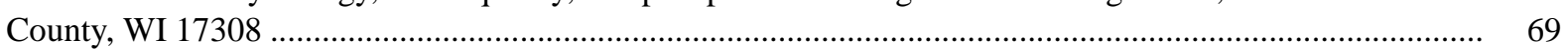

Hydrologic investigation of Powell Marsh and its relation to Dead Pike Lake, WI 17309 ............................... 71

Lauderdale Lakes restoration monitoring, WI 17310.............................................................................. 73

Water quality of the Red Cedar Lakes in response to hydrologic and phosphorus loading, WI 17311 ............... 75

Assessment of phosphorus loading, winter anoxia, and stage regulation of Little St. Germain Lake, Vilas

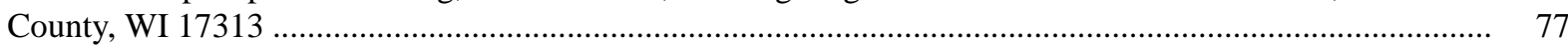

Assessment of the water quality, hydrology, and biology of Geneva Lake, WI 17314 .................................. 79

Determination of steamflow, phosphorus, and solids loads entering and leaving Sinissippi Lake, Dodge

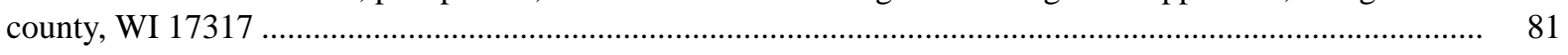

Hydrodynamic data collection for the design of Mc Cook Reservoir, WI 17318 ......................................... 83

Response of the St. Croix River pools to various phosphorus loading scenarios, WI 17319 ............................ 85

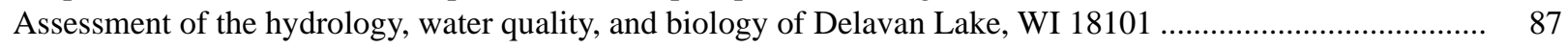

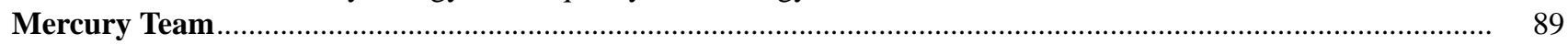

Florida Everglades mercury cycling, WI 19700................................................................................ 90

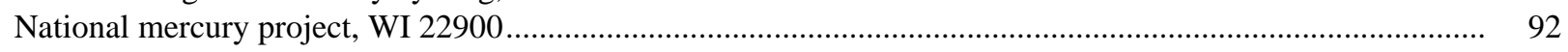

Multidisciplinary Water-Quality Assessment Team................................................................................... 95

Interagency Methods and Data Comparability Board (MDCB), WI 00303 .................................................. 97

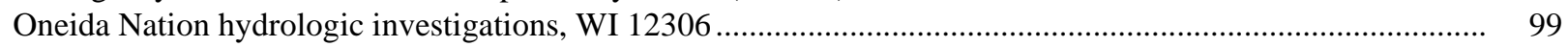

The surface water resources of the Ho-Chunk Tribe, WI 12311 ............................................................. 100

Western Lake Michigan drainages National Water-Quality Assessment (NAWQA), WI 17400 ...................... 101

Upper Illinois River Basin National Water-Quality Assessment (NAWQA), WI 17402 ................................. 104

National Water-Quality Assessment (NAWQA) special, WI 17403 ............................................................. 106

Demonstration of submerged vanes, Fish Creek, WI 19300 ........................................................................ 107

Hydrologic literature search and digital data compilation of Camp Wismer and proposed hydrologic
investigation of potential source areas of contamination at Camp Wismer, WI 19500 ................................. 109

National Environmental Methods Index, WI 21006 ............................................................................ 110

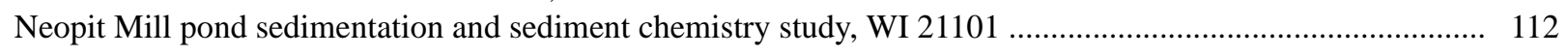

Whittlesey Creek hydrology study, WI 21500 .................................................................................... 113

St. Croix National Scenic Riverway—nutrient and sediment loading and long-term water-quality

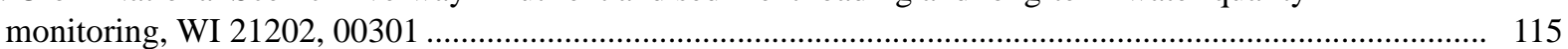

Historical ecosystem reconstruction and potential identification of effects of past ecosystem perturbations

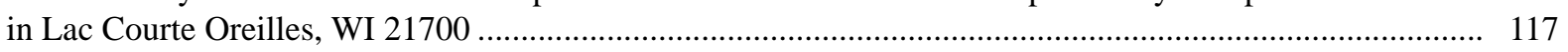

Milwaukee Metropolitan Sewerage District corridor study, WI 22500 ............................................... 118

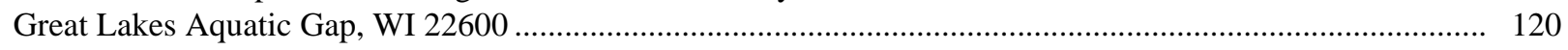

Kalamazoo River geomorphology study, WI 22700 ............................................................................ 121

Bad River geomorphology/streamflow trends, WI 23000 ......................................................................... 123

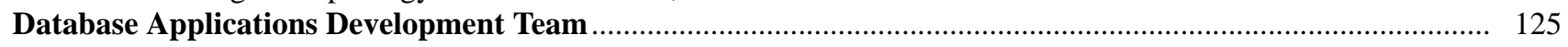

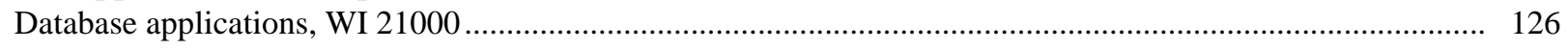

Wisconsin Department of Natural Resources biology database, WI 21005 ............................................. 128

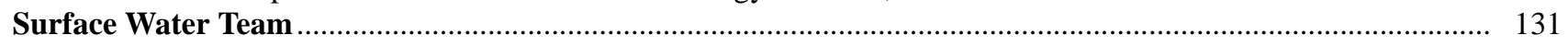

Amphibian malformations and water quality, WI 00102 ....................................................................... 133

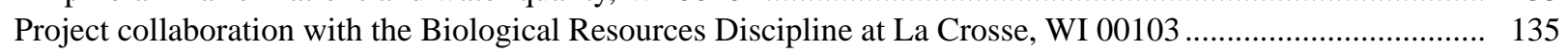

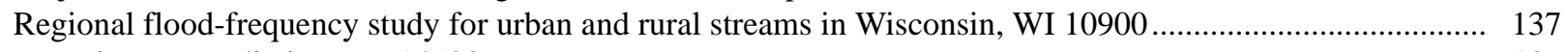

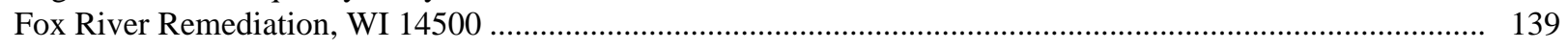




\section{CONTENTS-Continued}

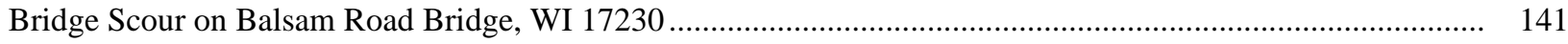

Dane County surface water model, WI 18901 ........................................................................................ 142

Transport of PCBs at two sites on Cedar Creek, WI 19100....................................................................... 143

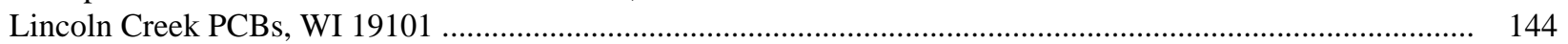

Transport of PCBs at three sites on Pine Creek and Manitowoc River (Hayton Millpond), WI 19102 .................. 145

Mitigation of future North Fork urbanization impacts on the Pheasant Branch hydrologic system,

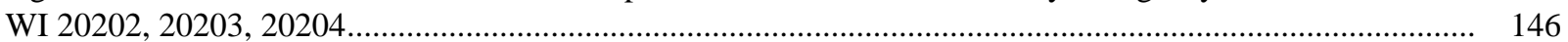

Modeling the effects of the Crandon Mine using the HSPF watershed model, WI 20500................................. 148

Geographic information system (GIS) database development and support of MODFLOW and HSPF

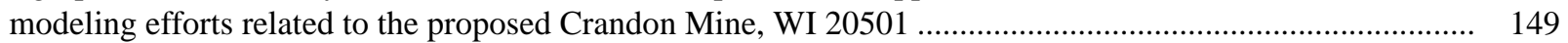

The effect of near-shore development on constituent loading to lakes in Northern Wisconsin, WI $21800 \ldots \ldots \ldots . . . \quad 151$

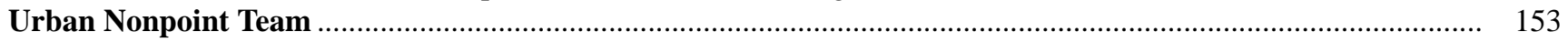

Verification of treatment performance of the vortechnics and stormwater management filter, WI 17207............ 155

Verification of pressurized stormwater filtration system at St. Mary's Hospital, WI 17208 .............................. 157

Thresholds of toxicity in urban streams, WI 17216 ............................................................................... 159

Calibration of the source loading and management model (SLAMM), WI 17219 ............................................. 161

Evaluating improved street sweeping for enhancing water quality in highway runoff in Milwaukee, WI 17231. 163

Evaluation of the effectiveness of low-impact development practices, WI 17233 ............................................ 165

Impacts of residential construction on streamwater quality, WI 17235 ........................................................ 167

Evaluation of street sweeping as a water-quality management tool in residential basins in Madison, WI 17237. 169

Educational BMP evaluation program for two basins in the city of Milwaukee, WI 17241 ............................... 171

Monitoring and evaluation of the impacts of aircraft and runway deicers on the Kinnickinnic River

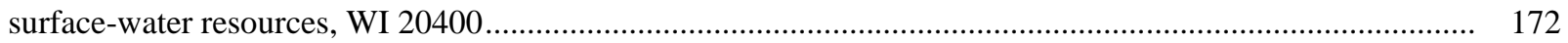

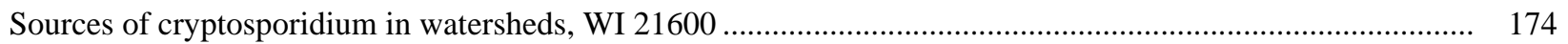

Occurrence and variability of pathogens in Wisconsin's urban streams, WI 22300........................................ 176

Collection of real-time and pathogen data at recreational beaches in Madison, WI 22800 ................................. 178

Water, Energy, and Biogeochemical Budgets Team .................................................................................... 181

Hydrologic and biochemical budgets in temperate lakes and their watersheds, northern Wisconsin, WI 17500 .. 182 


\section{BASIC MISSION AND PROJECTS \\ U.S. Geological Survey}

The U.S. Geological Survey was established by an act of Congress on March 3, 1879, to provide a permanent Federal agency to conduct the systematic and scientific "classification of the public lands, and examination of the geological structure, mineral resources, and products of national domain." An integral part of that original mission includes publishing and disseminating the earth-science information needed to understand, to plan the use of, and to manage the Nation's energy, land, mineral, and water resources.

Since 1879, the research and fact-finding role of the U.S. Geological Survey (USGS) has grown and has been modified to meet the changing needs of the Nation it serves. As part of the evolution, the USGS has become the Federal Government's largest earth-science research agency, the Nation's largest civilian map-making agency, the primary source of data on the Nation's surface-water and ground-water resources, and the employer of the largest number of professional earth scientists in the Nation. Today's programs serve a diversity of needs and users. Programs include:

Conducting detailed assessments of the energy and mineral potential of land and offshore areas.

Investigating and issuing warnings of earthquakes, volcanic eruptions, landslides, and other geologic and hydrologic hazards.

Conducting research on the geologic structure of land and offshore areas.

Studying the geologic features, structure, processes, and history of the other planets of our solar system.

Conducting topographic surveys and preparing topographic and thematic maps and related cartographic products.

Developing and producing digital cartographic data bases and products.

Collecting data on a routine basis to determine the quantity, quality, and use of surface water and ground water.

Conducting water-resource appraisals to describe the consequences of alternative plans for developing land and water resources.

Conducting research in hydraulics and hydrology, and coordinating all Federal water-data acquisition.

Using remotely sensed data to develop new cartographic, geologic, and hydrologic research techniques for natural resources planning and management.

Providing earth-science information through an extensive publications program and a network of public access points.

Manage water, biological, energy, and mineral resources.

Along with its continuing commitment to meet the growing and changing earth-science needs of the Nation, the USGS remains dedicated to its original mission to collect, analyze, interpret, publish, and disseminate information about the natural resources of the Nation-providing "Earth science in the public service." 


\section{WATER RESOURCES DISCIPLINE}

The mission of the Water Resources Discipline (WRD) is to provide the hydrologic information and understanding needed for the optimum utilization and management of the Nation's water resources for the overall benefit of the people of the United States. This mission is accomplished, in large part, through cooperation with other Federal and non-Federal agencies, by:

Collecting, on a systematic basis, data needed for the continuing determination and evaluation of the quantity, quality, and use of the Nation's water resources.

Conducting analytical and interpretive water-resource appraisals describing the occurrence, availability, and physical, chemical, and biological characteristics of surface water and ground water.

Conducting supportive basic and problem-oriented research in hydraulics, hydrology, and related fields of science to improve the scientific basis for investigations and measurement techniques and to understand hydrologic systems sufficiently well to quantitatively predict their response to stress.

Disseminating the water data and the results of these investigations and research through reports, maps, computerized information services, and other forms of public releases.

Coordinating the activities of Federal agencies in the acquisition of water data for streams, lakes, reservoirs, estuaries, and ground water.

Providing scientific and technical assistance in hydrologic fields to other federal, state, and local agencies, to licensees of the Federal Energy Regulatory Commission, and to international agencies on behalf of the U.S. Department of State.

Total funding $=\$ \mathbf{\$}, 512,000$

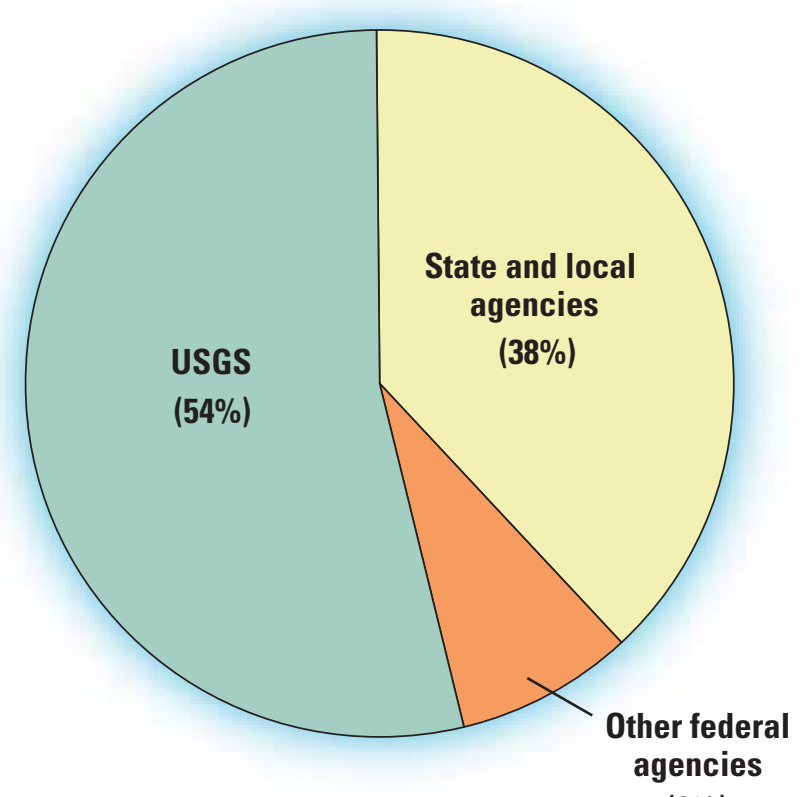

$(8 \%)$

Funding sources for the water-resources program in Wisconsin for the 2002 fiscal year. 


\section{Water Resources Discipline, Wisconsin District}

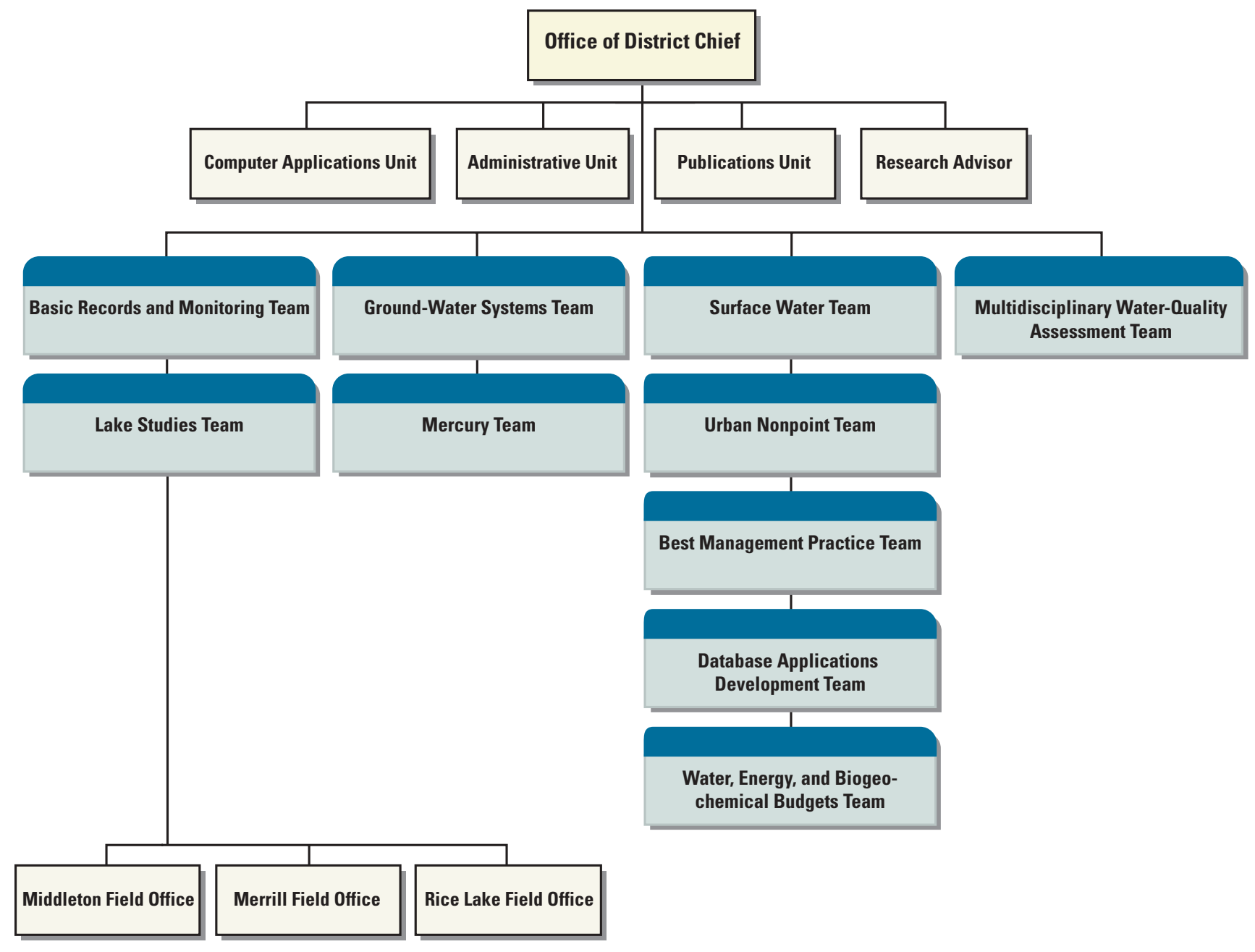

Organization chart of the U.S. Geological Survey, Water Resources Discipline, Wisconsin District. 


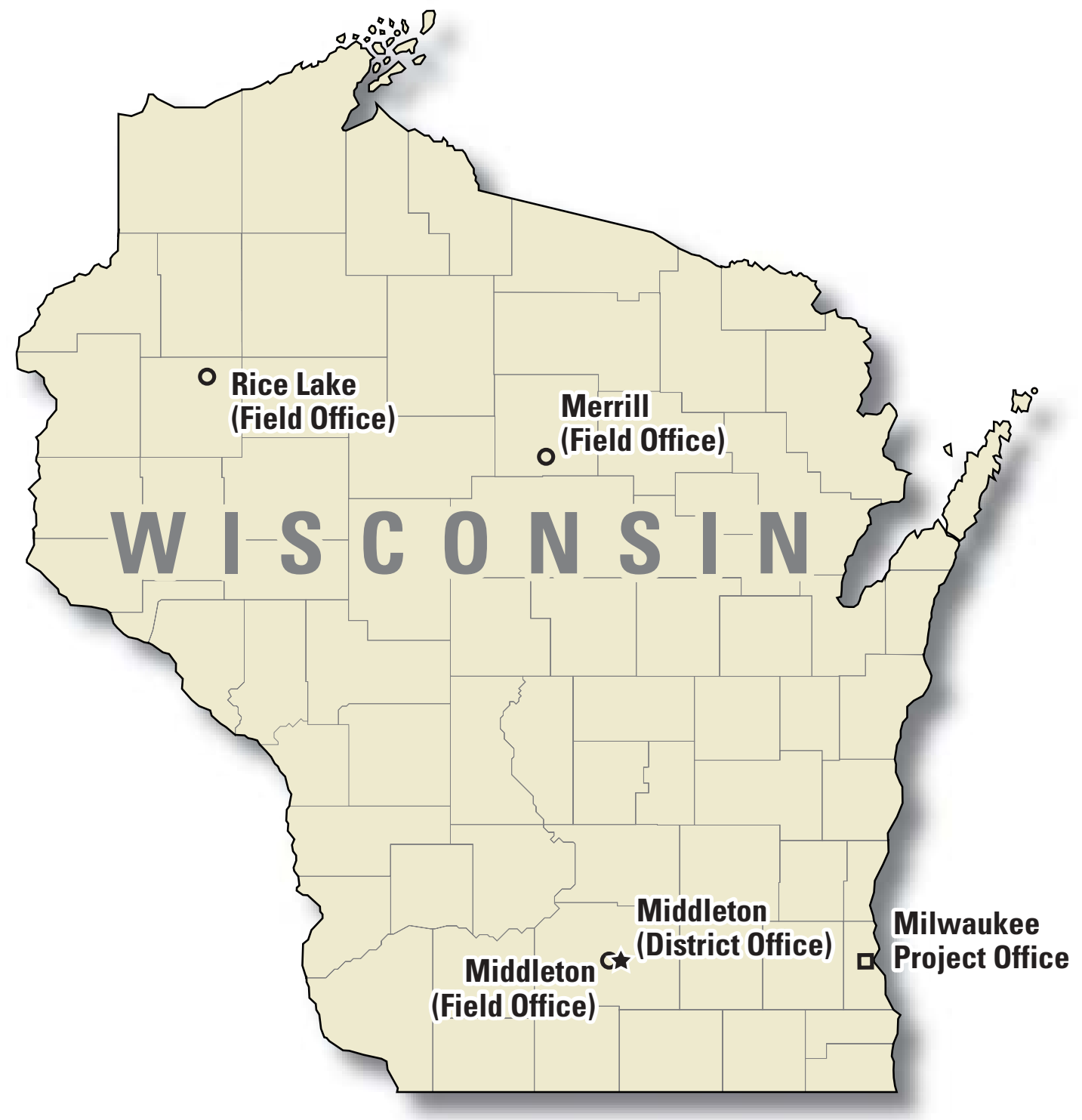

Location of offices in Wisconsin District. 


\section{COOPERATORS}

\section{State Agencies}

University of Wisconsin, Madison

Wisconsin Department of Agriculture, Trade, and Consumer Protection

Wisconsin Department of Natural Resources

Wisconsin Department of Transportation

Wisconsin Geological and Natural History Survey

Wisconsin State Laboratory of Hygiene

Florida Department of Environmental Protection

\section{Local Agencies}

City of Barron

City of Beaver Dam

City of Brookfield

City of Fond du Lac

City of Fort Atkinson

City of Hillsboro

City of Madison

City of Middleton

City of Milwaukee

City of Peshtigo

City of Sparta

City of Thorp

City of Waupun

County of Bayfield

County of Milwaukee

Dane County Lakes and Watershed Management

Dane County Land Conservation Department

Dane County Regional Planning Commission

Dane County Department of Planning \& Development

Fontana/Walworth Water Pollution Control Commission

Geneva Lake Environmental Agency

Green Bay Metropolitan Sewerage District

Joint Water Quality Commission of Danbury and St. Croix Chippewa Indians of Wisconsin

Madison Metropolitan Sewerage District

Marathon County Highway Department

Milwaukee Metropolitan Sewerage District

Rock County Public Works Department

Southeastern Wisconsin Regional Planning Commission

Village of Wittenberg

Walworth County Metropolitan Sewerage District

Other Federal Agencies

U.S. Army Corps of Engineers,

Detroit District

Rock Island District

St. Paul District

Vicksburg, MS

Federal Energy Regulatory Commission licensees

Black River Falls Municipal Utilities

\section{Other Federal Agencies (continued)}

Stora Enso, Niagra Mill

Dairyland Power Cooperative

Northern States Power Company

Northwoods Hydropower

Wisconsin Electric Power Company

Wisconsin Public Service Corporation

Wisconsin Valley Improvement Company

National Park Service

U.S. Environmental Protection Agency

Indian Tribes

Bad River Band of Lake Superior Chippewa

Lac Courte Oreilles Tribe

Lac du Flambeau Band of Lake Superior Chippewa

Menominee Indian Tribe of Wisconsin

Oneida Tribe of Indians of Wisconsin

St. Croix Tribe of Wisconsin

Stockbridge-Munsee Band of Mohican Indians

Sokaogon Chippewa Indians of Wisconsin

Ho-Chunk Nation of Wisconsin

\section{Lake Districts}

Benedict/Tombeau Lake Management District

Buffalo Lake District

City of Muskego

Eagle Spring Lake Management District

Green Lake Sanitary District

Lauderdale Lakes Lake Management District

Little Cedar Lake Protection and Rehabilitation District

Little Green Lake Protection and Rehabilitation District

Little Muskego Lake Management District

Little St. Germain Protection and Rehabilitation District

Middle Genesee Lake District

Okauchee Lake District

Pike Lake Management District

Potter Lake Rehabilitation and Protection District

Powers Lake District

Silver Lake Protection and Rehabilitation District

Whitewater Rice Lake Management District

Wind Lake Management District

Town of Delavan

Town of Hubbard

Town of Sand Lake

Town of Wascott

Village of Oconomowoc Lake

Village of Hustisford

Town of Baraboo 


\section{SUMMARY OF HYDROLOGIC CONDITIONS}

\section{Streamflow}

The statewide average precipitation of 34.83 inches for the 2001 water year was 3.15 inches greater than the normal annual precipitation of 31.68 inches for water years 1961-90. Average precipitation values affecting streamflow conditions ranged from 92 percent in northeast Wisconsin to 122 percent in southwest Wisconsin with a statewide average of 110 percent (summary tables provided by Lyle Anderson and Ed Hopkins, State Climatology Office, University of Wisconsin, Madison, written commun., 2002).

The year started out very dry with all regions of the state below 50\% of the long-term October average. November precipitation, which was approximately normal, was followed by a December which had record-setting snowfall in most of southern Wisconsin and heavier than normal snowfall the rest of the state. This snowfall total was boosted by the colder than normal temperatures that increased the snowfall depth for water content. The state had the first emergency snow declaration since 1979 with 14 counties receiving aid for December snow clean-up (Wisconsin State Journal, Dec. 15, 2001). Statewide precipitation in January was close to normal. February precipitation was above normal in northwest, north central and all of southern Wisconsin. Elsewhere in the state precipitation was close to normal. In March all regions of the state were very dry with total precipitation below $50 \%$ of the long-term March average. In April, the northwest corner of the state had precipitation over three times normal, north central had more than double normal and west central also had precipitation significantly above normal. The rest of the state was also above normal. In May, precipitation in the southern and central parts of the state was about 160 percent of normal. From mid June to mid July there was a statewide dry spell, with most of the state receiving less than 1 inch of rain. August precipitation was close to normal for most of the state with some localized very heavy rains of over 11 inches in southwest and south central Wisconsin. In September, the southern part of the state was above normal, the northwest part of the state was below normal and the rest of the state was about normal.

Runoff for rivers in the state ranged from 67 percent of the average annual runoff (1964-2001) at the Kewaunee River site in the northeast part of the state to 160 percent of the average annual runoff (1944-2001) at the Eau Galle River at Spring Valley site in the west central part of the state. Departures of runoff in the 2001 water year as a percent of long-term average runoff in the state (determined using stations with drainage areas greater than 150 square miles and at least 20 years of record) are shown in figure 4.
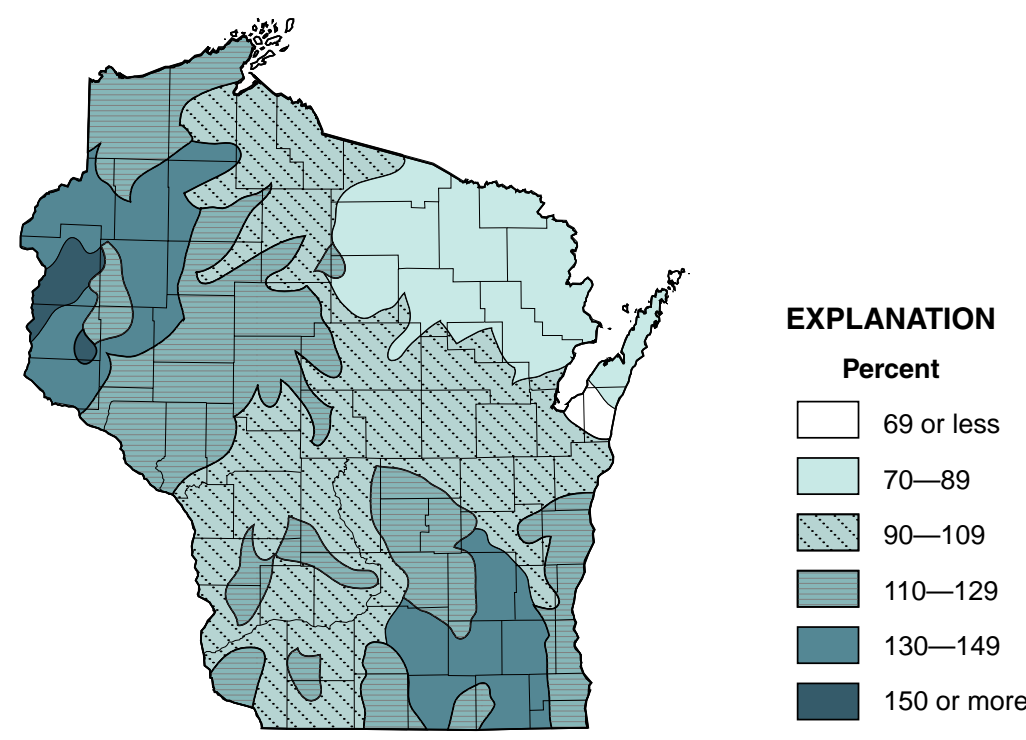

2001 runoff as percentage of long-term average runoff. 


\section{Water Quality}

Suspended-sediment yields from four watersheds in southern Wisconsin in water year 2001 ranged from 47 to 140 percent of normal, as indicated by loads measured at relatively long-term monitoring sites on these four watersheds. Sediment yields at Brant River in southwestern Wisconsin and Yahara River at Windsor in south-central Wisconsin were 47 and 64 percent of normal, respectively. Yields at Jackson Creek Tributary near Elkhorn in southeastern Wisconsin and Green Lake Inlet near Green Lake were 98 and 140 percent of normal, respectively.

Phosphorus yields in water year 2001 from three watershed in southern Wisconsin, on which there are longterm monitoring sites, ranged from 72 to 102 percent of normal. The phosphorus yield for Yahara River at Windsor was 72 percent of normal, the yield for Jackson Creek Tributary was 95 percent of normal, and the yield for Green Lake Inlet was 102 percent of normal.

\section{Ground-Water Levels}

In general, shallow ground-water levels during the 2001 water year were normal to above normal for most of the wells in the State. Wells in Dane, Grant, and LaFayette Counties had below normal ground-water levels at the beginning of the water year, and these levels remained below normal for the entire water year. The large extent of normal and above-normal ground-water levels can be attributed to near normal rainfall during the 2001 water year and normal rainfall during the previous water year.

Further information about the hydrologic information for Wisconsin can be found in "Water Resources DataWisconsin, Water Year 2001." 


\section{BASIC RECORDS AND MONITORING TEAM}

\section{Mission}

Collect, store, compile, and disseminate waterresources data that address relevant issues and are responsive to the needs of customers and the general public. Provide relevant, credible, impartial, and timely data for understanding hydrologic systems, planning developments, designing facilities, forecasting floods, operating dams, wastewater treatment, and water-supply plants, managing lakes and wetlands, abating and preventing pollution, modeling, determining trends, and determining the occurrence and distribution of water and its quality. The real-time and historical data will be disseminated and made available to customers and the public in various forms and media including the Internet, direct computer access, computer disks and tape, and printed reports.

\section{Team Members}

Robert J. Waschbusch, Hydrologist

Herbert S. Garn, Hydrologist

William J. Rose, Hydrologist/Engineering

Daniel L. Olson, Hydrologic Technician

Bernard R. Ellefson, Hydrologic Technician

Halward L. Hanson, Hydrologic Technician

David E. Housner, Hydrologic Technician

Patricia A. Stark, Hydrologic Assistant

Josef H. Habale, Hydrologic Technician

Kenneth R. Koenig, Hydrologic Technician

Steven A. March, Hydrologic Technician

Thomas A. Wittwer, Hydrologic Technician

Thomas J. Popowski, Hydrologic Technician

Josef G. Schuler, Hydrologic Technician

Jeffrey J. Hanig, Hydrologic Technician

Paulette R. Homant, Hydrologic Technician

Brent W. Olson, Hydrologic Technician

Brett M. Esser, Hydrologic Technician

James M. Rauman, Hydrologic Technician

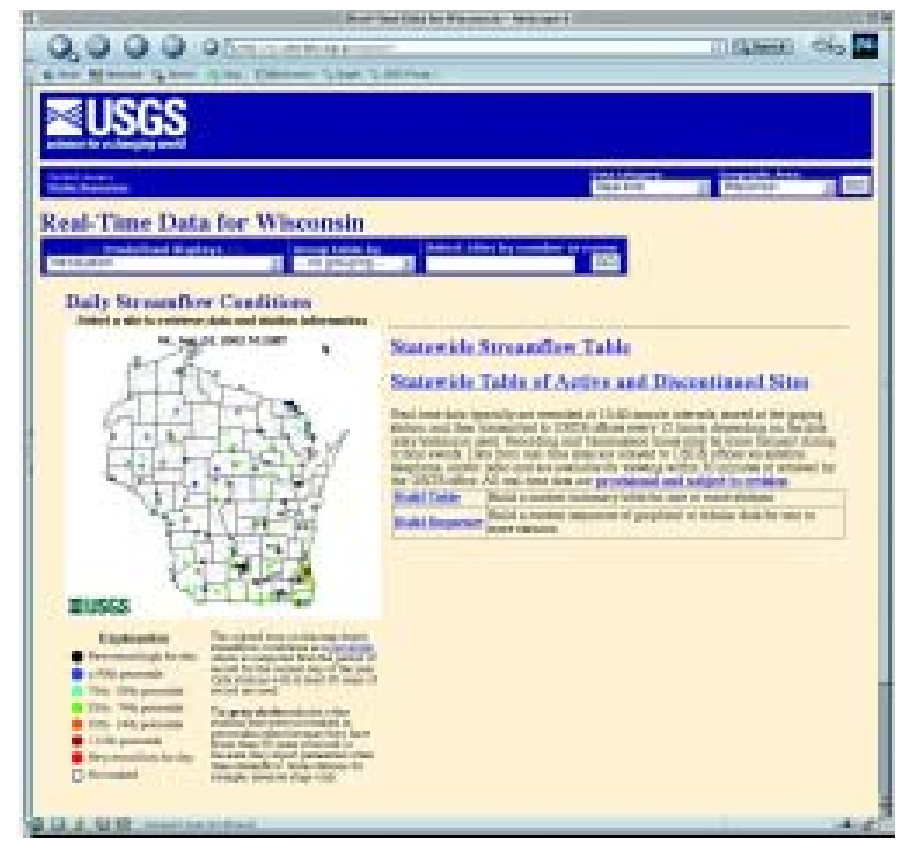




\section{PROJECTS}

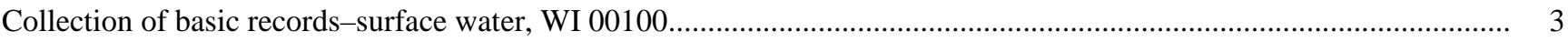

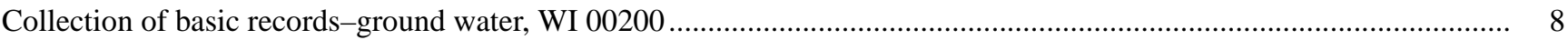

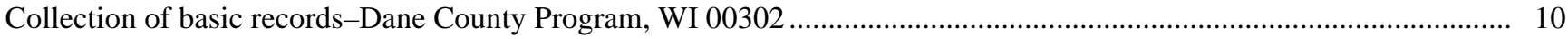

Water-quality monitoring of Fox River and tributaries, Green Lake County, WI 00304 .............................................12

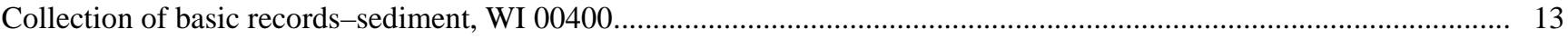

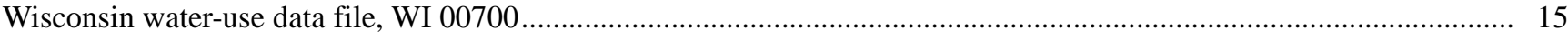

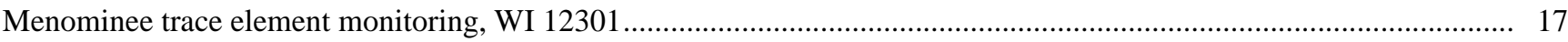




\section{COLLECTION OF BASIC RECORDS-SURFACE WATER}

\section{PROJECT CHIEF:}

Robert J. Waschbusch

\section{LOCATION:}

Statewide

PROJECT NUMBER:

WI 00100

PERIOD OF PROJECT:

July 1913-Continuing
Grant River at Burton, Wis. (Station \#05413500)

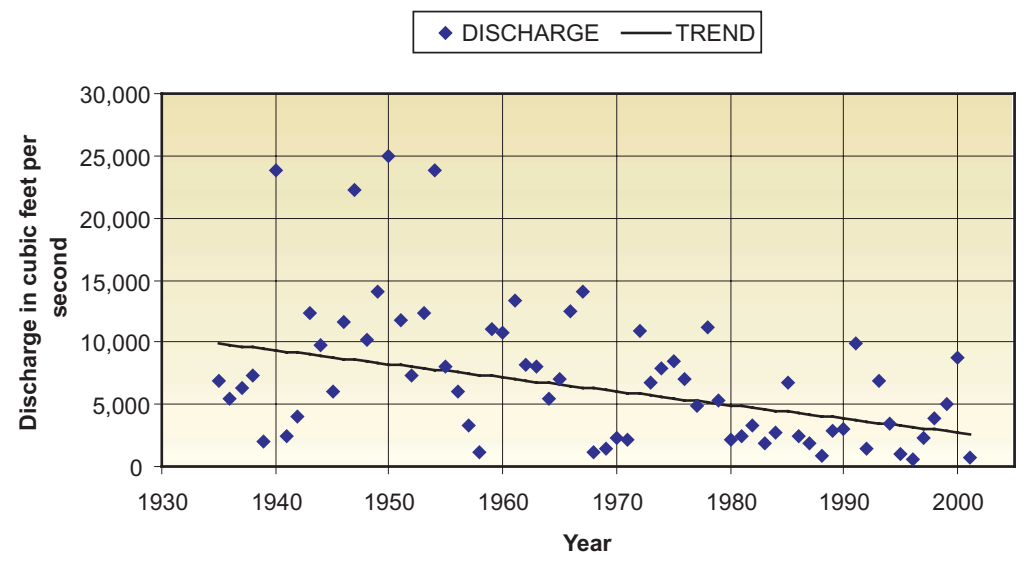

Trend analysis showing decreasing trend in annual peak discharge, 1935-2001.

\section{COOPERATORS}

Bad River Band of Lake Superior Chippewa Indians

City of Barron

City of Beaver Dam

City of Fort Atkinson

City of Hillsboro

City of Peshtigo

City of Sparta

City of Thorp

City of Waupun

Dane County Department of Planning and Development

Dane County Regional Planning Commission

Federal Energy Regulatory Commission Licensees

Black River Falls Municipal Utilities

Dairyland Power Cooperative

Northern States Power Company

Stora Enso, Niagra Mill

Wisconsin Electric Power Company

Wisconsin Public Service Corporation

Wisconsin Valley Improvement Company

Fontana/Walworth Water Pollution Control Commission

Green Bay Metropolitan Sewerage District

Illinois Department of Transportation

Kickapoo Valley Reserve

Lac du Flambeau Band of Lake Superior Chippewa

Madison Metropolitan Sewerage District

Menominee Indian Tribe of Wisconsin
Mole Lake Sokaogon Chippewa Community

Oneida Tribe of Indians of Wisconsin

Rock County Public Works Department

Southeastern Wisconsin Regional Planning Commission

City of Racine

Kenosha Water Utility

Milwaukee Metropolitan Sewerage District

Waukesha County

Stockbridge-Munsee Band of Mohican Indians

U.S. Army Corps of Engineers

Village of Wittenberg

Village of Westport

Walworth County Metropolitan Sewerage District

Wisconsin Department of Natural Resources

Wisconsin State Historical Society-Wade House

Historic Site

\section{PROBLEM}

Surface-water information is needed for surveillance, planning, design, hazard warning, operation, and management in water-related fields such as water supply, hydroelectric power, flood control, irrigation, bridge and culvert design, wildlife management, pollution abatement, flood-plain management, and water-resources development. An appropriate database is necessary to provide this information. 


\section{OBJECTIVE}

The objectives of this study are to provide continuous discharge records for selected rivers at specific sites to supply the needs for regulation, analytical studies, definition of statistical properties, trends analysis, determination of the occurrence, and distribution of water in streams for planning. The project is also designed to determine lake levels and to provide discharge for floods, low-flow conditions, and for waterquality investigations. Requests for streamflow data and information relating to streamflow in Wisconsin are answered. Basic data are published annually in the report "Water Resources Data-Wisconsin."

\section{APPROACH}

A network of streamflow stations and lake-level stations will be maintained throughout Wisconsin. This includes operating the equipment at the gaging station to record river or lake stage, making periodic discharge measurements at each streamflow station to establish or verify a stage-discharge rating curve, reducing the stage records to instantaneous and daily discharges, compilation of monthly and annual discharges, and preparing data for publication in the annual report "Water Resources Data-Wisconsin."

\section{PROGRESS (July 2001 to June 2002)}

During the current fiscal year, streamflow data were collected at a total of 121 sites and lake-level data were collected at six. These sites are listed in the following table, "Surface-Water Gaging Stations Expected to be Operated in 2003 FY." A map showing the location of all continuous-record streamflow-gaging stations in Wisconsin is shown on page 5 .

Computation of streamflow and lake-level records for all the network stations for the 2001 water year was completed, stored in our NWIS computer database, and published in the annual report "Water Resources DataWisconsin, Water Year 2001."

\section{PLANS (July 2002 to June 2003)}

Data will be collected at 118 continuous-streamflow stations (see the following list) and lake levels at 6 stations. Streamflow records will be computed and data published for the 2002 water year. Requests for streamflow information will be answered. 
SURFACE-WATER GAGING STATIONS EXPECTED TO BE OPERATED IN 2003 FY

\begin{tabular}{|c|c|c|c|c|}
\hline $\begin{array}{l}\text { Station } \\
\text { number }\end{array}$ & Name and location & $\begin{array}{c}\text { Drainage } \\
\text { Area }\end{array}$ & $\begin{array}{l}\text { Period of record } \\
\text { (water year) }\end{array}$ & Cooperator \\
\hline \multicolumn{2}{|c|}{464646092052900 Superior Bay, Duluth Ship Canal at Duluth, MN } & 4200 & 1994- & $\mathrm{C}$ of E, Detroit \\
\hline 04024430 & Nemadji River - South Superior & 420 & $1974-$ & WDNR \\
\hline 04025500 & Bois Brule River - Brule & 118 & $1943-81,1984-$ & USGS Federal Program \\
\hline 04027000 & Bad River - Odanah & 597 & $1914-22,1948-$ & $\begin{array}{l}\text { Bad River Band of Lake } \\
\text { Superior Chippewa Indians }\end{array}$ \\
\hline 04027500 & White River - Ashland & 301 & $1948-$ & NSP/WDNR \\
\hline 04029990 & Montreal River - Saxon Falls & 262 & 1987 & NSP/WDNR \\
\hline 04063700 & Popple River - Fence & 139 & 1964- & USGS Federal Program \\
\hline 04064500 & Pine River - Pine River Powerplant - Florence & 533 & $1924-76,1996-$ & WEPCO/WDNR \\
\hline 04065106 & Menominee River - Niagara & 2470 & 1993- & FERC \\
\hline 04066003 & Menominee River - Pembine & 3140 & $1950-$ & WEPCO/WDNR \\
\hline 04066030 & Menominee River - White Rapids Dam - Banat, MI & 3190 & 1999- & FERC \\
\hline 04066500 & Pike River - Amberg & 255 & 1914-70, 2000- & USGS Federal Program \\
\hline 04066800 & Menominee River - Koss, MI & 3700 & $\begin{array}{l}\text { 1907-09, 1913-81, } \\
1998-\end{array}$ & FERC \\
\hline 04067500 & Menominee River - McAllister & 3930 & $\begin{array}{l}1945-61,1979-86 \\
1988-90,1993-95,1\end{array}$ & $\begin{array}{l}\text { WDNR } \\
1998-\end{array}$ \\
\hline 04067958 & Peshtigo River - Wabeno & 447 & $1998-$ & WPS/WDNR \\
\hline 04069416 & Peshtigo River - Porterfield & 1020 & 1998- & FERC \\
\hline 04069500 & Peshtigo River - Peshtigo & 1080 & 1953- & City of Peshtigo \\
\hline 04071000 & Oconto River - Gillett & 705 & 1906-09, 1914- & USGS Federal Program \\
\hline 04071765 & Oconto River - Oconto & 966 & $1989-90,1998-$ & WDNR \\
\hline 04072150 & Duck Creek - Howard & 108 & $1988-$ & Oneida Tribe of Indians of WI \\
\hline 04073365 & Fox River - Princeton & 962 & 2001- & USGS Federal Program \\
\hline 04073500 & Fox River - Berlin & 1340 & $1898-$ & $\mathrm{C}$ of E, Detroit \\
\hline 04074538 & Swamp Creek - above Rice Lake at Mole Lake & 46.3 & $\begin{array}{l}1977-83, \\
1984-86,2001-\end{array}$ & Sokaogan Chippewa Community \\
\hline 04074548 & Swamp Creek - below Rice Lake at Mole Lake & 56.8 & $\begin{array}{l}1977-79 \\
1982-85,2001-\end{array}$ & Sokaogan Chippewa Community \\
\hline 04074950 & Wolf River - Langlade & 463 & 1966-79, 1981- & Menominee Indian Tribe of WI \\
\hline 004077630 & Red River - Morgan & 114 & 1993 & $\begin{array}{l}\text { Stockbridge-Munsee Band of } \\
\text { Mohican Indians }\end{array}$ \\
\hline 0407809265 & Middle Branch Embarrass River - Wittenberg & 76.3 & $1990-$ & Village of Wittenberg \\
\hline 04078500 & Embarrass River - Embarrass & 384 & $1919-85,1994-$ & USGS Federal Program \\
\hline 04079000 & Wolf River - New London & 2260 & $1896-$ & C of E, Detroit \\
\hline 04082400 & Fox River - Oshkosh & 5310 & 1991 & $\mathrm{C}$ of E, Detroit \\
\hline 04084445 & Fox River - Appleton & 5950 & $1986-$ & $\mathrm{C}$ of E, Detroit \\
\hline 04084500 & Fox River - Rapide Croche Dam - Wrightstown & 6010 & $1896-$ & LFRDA/WDNR \\
\hline 040851385 & Fox River - Oil Tank Depot - Green Bay & 6330 & $1989-$ & Green Bay MSD \\
\hline 04085200 & Kewaunee River - Kewaunee & 127 & 1964-96, 1998- & WDNR \\
\hline 04085395 & S.Br. Manitowoc River - Hayton & 109 & 1993- & WDNR \\
\hline 04085427 & Manitowoc River - Manitowoc & 526 & $1972-96,1998-$ & WDNR \\
\hline 04085746 & Mullet River - Greenbush & 24.3 & $2001-$ & Wisconsin State Historical Soc. \\
\hline 04086000 & Sheboygan River - Sheboygan & 418 & $1916-24,1951-$ & WDNR \\
\hline 04086500 & Cedar Creek - Cedarburg & 120 & $\begin{array}{l}1930-70,73-81 \\
1983-87,1991-\end{array}$ & WDNR \\
\hline 04086600 & Milwaukee River - Pioneer Road - Cedarburg & 607 & $1982-$ & SEWRPC \\
\hline 04087000 & Milwaukee River - Milwaukee & 696 & 1914- & SEWRPC \\
\hline 04087030 & Menomonee River - Menomonee Falls & 34.7 & $1975-77,1979$ & SEWRPC \\
\hline 04087088 & Underwood Creek - Wauwatosa & 18.2 & $1975-$ & SEWRPC \\
\hline 04087120 & Menomonee River - Wauwatosa & 123 & $1962-$ & SEWRPC \\
\hline 04087160 & Kinnickinnic River - Milwaukee & 20.4 & 1976- & SEWRPC \\
\hline 04087204 & Oak Creek - South Milwaukee & 25 & $1964-$ & SEWRPC \\
\hline 04087220 & Root River - Franklin & 49.2 & $1964-$ & SEWRPC \\
\hline 04087233 & Root River Canal - Franklin & 57 & $1964-$ & SEWRPC \\
\hline 04087240 & Root River - Racine & 190 & $1963-$ & SEWRPC \\
\hline 04087257 & Pike River - Racine & 38.5 & 1972- & SEWRPC \\
\hline 05332500 & Namekagon River - Trego & 488 & $1928-70,1988$ & NSP/WDNR \\
\hline 05333500 & St. Croix River - Danbury & 1580 & $1914-81,1984-$ & USGS Federal Program \\
\hline 05340500 & St. Croix River - St. Croix Falls & 6240 & $1902-$ & NSP/WDNR \\
\hline 05341500 & Apple River - Somerset & 579 & $1901-70,1987$ & NSP/WDNR \\
\hline 05356000 & Chippewa River - Winter & 790 & $1912-$ & NSP/WDNR \\
\hline 05356500 & Chippewa River - Bruce & 1650 & 1914- & NSP/WDNR \\
\hline 05357254 & Trout River - CTH H - Boulder Junction & 58.9 & 1999- & $\begin{array}{l}\text { Lac du Flambeau Band of Lake } \\
\text { Superior Chippewa (LDF) }\end{array}$ \\
\hline 05357335 & Bear River - Manitowish Waters & 81.3 & 1991 & LDF \\
\hline 05360500 & Flambeau River - Bruce & 1860 & $1951-$ & NSP/WDNR, FERC \\
\hline 05362000 & Jump River - Sheldon & 576 & $1915-$ & USGS Federal Program \\
\hline 05365500 & Chippewa River - Chippewa Falls & 5650 & $1888-1983,1987$ & NSP/WDNR \\
\hline 05365707 & North Fork Eau Claire River - Thorp & 51 & 1986 & City of Thorp \\
\hline 053674464 & Yellow River - Barron & 153 & 1991 & City of Barron \\
\hline 05368000 & Hay River - Wheeler & 418 & 1951- & USGS Federal Program \\
\hline 05369000 & Red Cedar River - Menomonie & 1770 & 1907-08, 1913- & NSP/WDNR \\
\hline 05369500 & Chippewa River - Durand & 9010 & $1928-$ & C of E, St. Paul \\
\hline 05369900 & Eau Galle River - Woodville & 39.4 & $2001-$ & C of E, St. Paul \\
\hline 05370000 & Eau Galle River - Spring Valley & 64.1 & $1944-$ & C of E, St. Paul \\
\hline
\end{tabular}


SURFACE-WATER GAGING STATIONS EXPECTED TO BE OPERATED IN 2003 FY-Continued

\begin{tabular}{|c|c|c|c|c|}
\hline $\begin{array}{l}\text { Station } \\
\text { number }\end{array}$ & Name and location & $\begin{array}{c}\text { Drainage } \\
\text { Area }\end{array}$ & $\begin{array}{l}\text { Period of record } \\
\text { (water year) }\end{array}$ & Cooperator \\
\hline 05379400 & Trempealeau River - Arcadia & 606 & 1960-77, 2001- & USGS Federal Program \\
\hline 05379500 & Trempealeau River - Dodge & 643 & 1914-19, 1934 & C of E, St. Paul \\
\hline 05381000 & Black River - Neillsville & 749 & $1905-09,1914-$ & USGS Federal Program \\
\hline 053813595 & Black River - Black River Falls & 1590 & 1985- & $\begin{array}{l}\text { C of E, St. Paul, City of Black } \\
\text { River Falls }\end{array}$ \\
\hline 05382000 & Black River - Galesville & 2080 & 1932- & C of E, St. Paul \\
\hline 05382325 & La Crosse River - Sparta & 167 & $1992-$ & City of Sparta \\
\hline 05383075 & La Crosse River - LaCrosse & 471 & $2000-$ & WDNR \\
\hline 05391000 & Wisconsin River - Lake Tomahawk & 757 & 1936- & WVIC/WDNR \\
\hline 05393500 & Spirit River - Spirit Falls & 81.6 & $1942-$ & WVIC/WDNR \\
\hline 05394500 & Prairie River - Merrill & 184 & 1914-31, 1939 & WVIC/WDNR \\
\hline 05395000 & Wisconsin River - Merrill & 2760 & $1903-$ & WVIC/WDNR \\
\hline 05397500 & Eau Claire River - Kelly & 375 & 1914-27, 1939- & WVIC/WDNR \\
\hline 05398000 & Wisconsin River - Rothschild & 4020 & $1945-$ & WVIC/WDNR \\
\hline 05399500 & Big Eau Pleine River - Stratford & 224 & 1914-26, 1937- & WVIC/WDNR \\
\hline 05400760 & Wisconsin River - Wisconsin Rapids & 5420 & $1914-50,1958-$ & WVIC/WDNR \\
\hline 05401050 & Tenmile Creek - Nekoosa & 73.3 & $\begin{array}{l}\text { 1963-79, 1988-94, } \\
1998-\end{array}$ & WDNR \\
\hline 05402000 & Yellow River - Babcock & 215 & $1944-$ & WVIC/WDNR \\
\hline 05404000 & Wisconsin River - Wisconsin Dells & 8090 & 1935- & WVIC/WDNR \\
\hline 05404116 & S. Br. Baraboo River - Hillsboro & 39.1 & $1988-$ & City of Hillsboro \\
\hline 05405000 & Baraboo River - Baraboo & 609 & 1914-22, 1943- & USGS Federal Program \\
\hline 05406500 & Black Earth Creek - Black Earth & 45.6 & $1954-$ & DCRPC \\
\hline 05407000 & Wisconsin River - Muscoda & 10400 & 1903-04, 1914- & C of E, St. Paul \\
\hline 054070396 & Fennimore Fork near Castle Rock & 21.7 & 2001- & WDNR \\
\hline 05407470 & Kickapoo River - Ontario & 151 & 2001- & USGS Federal Program \\
\hline 05408000 & Kickapoo River - LaFarge & 266 & 1939- & Kickapoo Reserve \\
\hline 05410490 & Kickapoo River - Steuben & 687 & 1933- & C of E, St. Paul \\
\hline 05413500 & Grant River - Burton & 269 & 1935- & $\mathrm{C}$ of $\mathrm{E}, \mathrm{R}$. Island \\
\hline 05414000 & Platte River - Rockville & 142 & 1935- & $\mathrm{C}$ of $\mathrm{E}, \mathrm{R}$. Island \\
\hline 05423500 & S. Br. Rock River - Waupun & 63.6 & $1948-69,1987$ & City of Waupun \\
\hline 05425500 & Rock River - Watertown & 969 & 1931-70, 1977- & $\begin{array}{l}\text { C of E, R. Island, Rock County } \\
\text { PWD }\end{array}$ \\
\hline 05425912 & Beaverdam River - Beaver Dam & 157 & $1984-$ & City of Beaver Dam \\
\hline 05426000 & Crawfish River - Milford & 762 & 1931- & $\begin{array}{l}\text { Rock County PWD, } \\
\text { Jefferson County }\end{array}$ \\
\hline 05426250 & Bark River - Rome & 122 & $1980-$ & SEWRPC \\
\hline 05427570 & Rock River - Indianford & 2630 & 1975- & Rock County PWD \\
\hline 05427850 & Yahara River at Hwy. 113 at Madison & 114 & $2002-$ & $\begin{array}{l}\text { WDNR, Town of Westport, } \\
\text { DCRPC }\end{array}$ \\
\hline 05429500 & Yahara River - McFarland & 327 & $1930-$ & DCDP\&D \\
\hline 05430150 & Badfish Creek - Cooksville & 82.6 & $1977-$ & MMSD \\
\hline 05430175 & Yahara River - Fulton & 517 & 1977 & MMSD \\
\hline 05430500 & Rock River - Afton & 3340 & 1914- & $\mathrm{C}$ of $\mathrm{E}, \mathrm{R}$. Island \\
\hline 05431032 & Turtle Creek - Delavan & 83.3 & 1996- & WALCOMET \\
\hline 05431486 & Turtle Creek - Clinton & 199 & $1939-$ & $\begin{array}{l}\text { C of E, Rock Island, } \\
\text { WALCOMET }\end{array}$ \\
\hline 05432500 & Pecatonica River - Darlington & 273 & $1939-$ & $\mathrm{C}$ of $\mathrm{E}, \mathrm{R}$. Island \\
\hline 05433000 & E. Br. Pecatonica River - Blanchardville & 221 & 1939-1986, 1988 & $\mathrm{C}$ of $\mathrm{E}, \mathrm{R}$. Island \\
\hline 05434500 & Pecatonica River - Martintown & 1034 & 1940- & $\mathrm{C}$ of $\mathrm{E}, \mathrm{R}$. Island \\
\hline 05435943 & Badger Mill Creek - Verona & 20.3 & $1997-$ & MMSD \\
\hline 05436500 & Sugar River - Brodhead & 523 & 1914- & C of E, Rock Island \\
\hline 05438283 & Piscasaw Creek - Walworth & 9.58 & $1992-$ & Fontana/Walworth WPCC \\
\hline 05543830 & Fox River - Waukesha & 126 & 1963- & SEWRPC \\
\hline 05544200 & Mukwonago River - Mukwonago & 74.1 & 1973- & SEWRPC \\
\hline 05545750 & Fox River - New Munster & 811 & $1940-$ & IL. DOT \\
\hline \multicolumn{5}{|l|}{ LAKES } \\
\hline 04082500 & Lake Winnebago - Oshkosh & 5880 & $1882-$ & $\mathrm{C}$ of E, Detroit \\
\hline 04084255 & Lake Winnebago - Stockbridge & 5880 & 1983- & C of E, Detroit \\
\hline 05404500 & Devil's Lake - Baraboo & 4.79 & $\begin{array}{l}1922-30,1932 \\
1934-81,1985-\end{array}$ & WDNR \\
\hline 05427235 & Lake Koshkonong - Newville & 2560 & 1987 & Rock County PWD \\
\hline 05428000 & Lake Mendota - Madison & 233 & 1903, 1916- & DCDPW \\
\hline 05429000 & Lake Monona - Madison & 279 & $1915-$ & DCDPW \\
\hline
\end{tabular}

C of E, Detroit - Corps of Engineers, Detroit, Michigan

$\mathrm{C}$ of E, R. Island - Corps of Engineers, Rock Island, Illinois

C of E, St. Paul - Corps of Engineers, St. Paul, Minnesota DCDP\&D - Dane County Department of Planning and Development DCRPC - Dane County Regional Planning Commission

FERC - Federal Energy Regulatory Commission Licensees

Fontana/Walworth WPCC - Fontana/Walworth Water Pollution

Control Commission

Green Bay MSD - Green Bay Metropolitan Sewerage District

IL. DOT - Illinois Department of Transportation
LFRDA - Lower Fox River Dischargers' Association

MMSD - Madison Metropolitan Sewerage District

NSP - Northern States Power Company

Rock County PWD - Rock County Public Works Department

SEWRPC - Southeastern Wisconsin Regional Planning Commission

WALCOMET - Walworth County Metropolitan Sewerage District

WDNR - Wisconsin Department of Natural Resources

WEPCO - Wisconsin Electric Power Company

WPS - Wisconsin Public Service

WVIC - Wisconsin Valley Improvement Company 


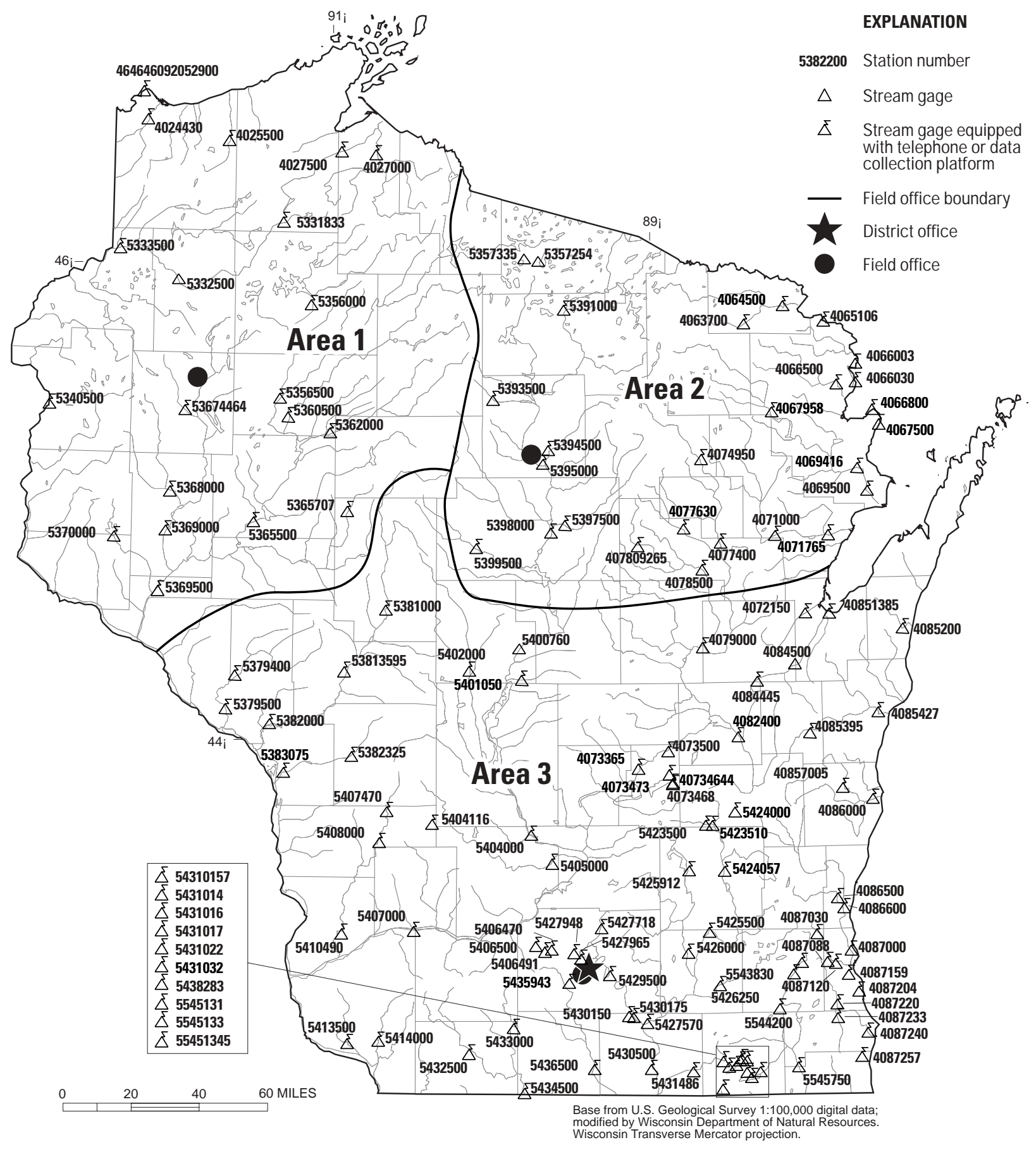

Location of continuous-record data-collection stations. 


\section{COLLECTION OF BASIC RECORDS-GROUND WATER}

\section{COOPERATOR:}

Wisconsin Geological and Natural History Survey

PROJECT CHIEF:

Bernard R. Ellefson

\section{LOCATION:}

Statewide

PROJECT NUMBER:

WI 00200

PERIOD OF PROJECT:

July 1946-Continuing

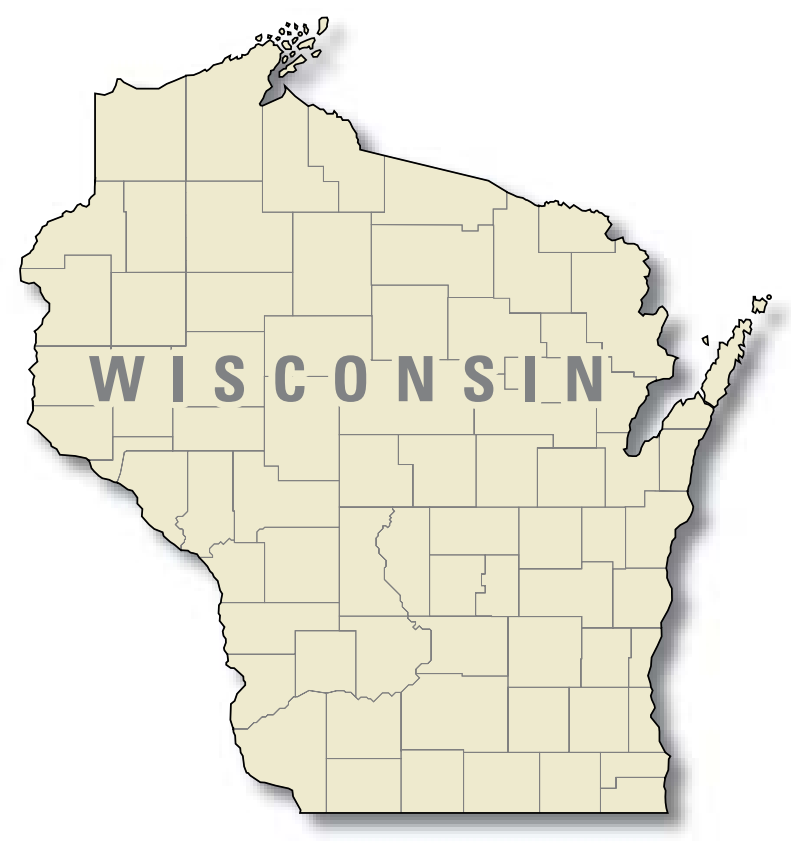

PROGRESS (July 2001 to June 2002)

Routine data collection and data being collected by observers is evaluated and entered into the database. Installed equipment to collect realtime data at three sites. Water-level data for the annual report, "Water Resources Data-Wisconsin, Water Year 2001" was completed. Water level data for all observation wells was made available on the Internet at http://wi.water.usgs.gov.

\section{PLANS (July 2002 to June 2003)}

Plans include: (1) continue measurements on the observation-well network, (2) replace and hire new observers and make quality-assurance checks when possible, and (3) data evaluation and preparation for the annual report.

\section{REPORTS}

Patterson, G.L., and Zaporozec, A., 1988, Analysis of waterlevel fluctuations in Wisconsin wells: Wisconsin Geo- 
logical and Natural History Survey Information Circular 63, $38 \mathrm{p}$.

Erickson, R.M., and Cotter, R.D., 1983, Trends in groundwater levels in Wisconsin through 1981: Wisconsin Geological and Natural History Survey Information Circular No. 43, 139 p.
Erickson, R.M., 1972, Trends in ground-water levels in Wisconsin, 1967-71: Wisconsin Geological and Natural History Survey Information Circular No. 21, 40 p.

Devaul, R.W., 1967, Trends in ground-water levels in Wisconsin through 1966: Wisconsin Geological and Natural History Survey Information Circular No. 9, 109 p. 


\section{COLLECTION OF BASIC RECORDS- DANE COUNTY PROGRAM}

COOPERATOR:
Dane County Regional Planning
Commission
PROJECT CHIEF:
Herbert S. Garn
LOCATION:
Dane County
PROJECT NUMBER:
WI 00302
PERIOD OF PROJECT:
Continuing

\section{PROBLEM}

A long-term base of water-quality data is needed for water-resource planning and assessment of water quality in the lakes and streams of Dane County.

\section{OBJECTIVE}

The objectives of this program are to determine suspended-sediment and phosphorus loads of selected tributaries to Lake Mendota and to collect data to identify long-term changes in base-flow water quality in selected streams in Dane County.

\section{APPROACH}

Streamflow-monitoring stations with automatic water-quality samplers are operated on three tributaries to Lake Mendota. Samples for analysis of suspendedsediment and phosphorus concentrations are collected at low flow and during periods when surface runoff is entering the streams. The concentration and streamflow data are used to compute annual suspended-sediment and total-phosphorus loads for the stations. Various

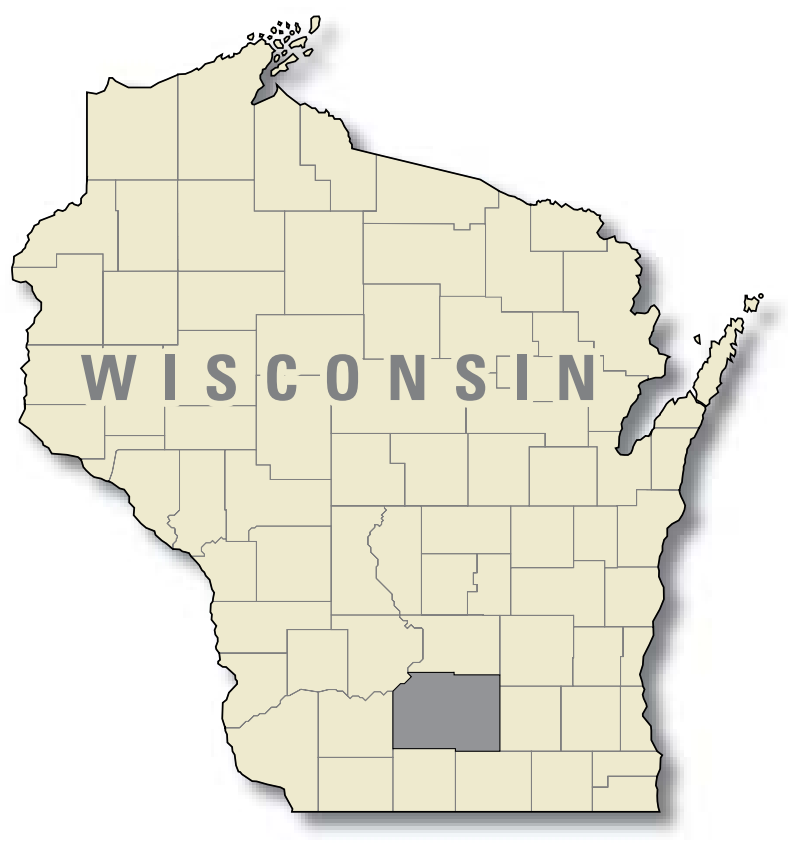

water-quality constituents are measured six times during the year at base flow of selected streams in the county.

\section{PROGRESS (July 2001 to June 2002)}

Streamflow and water-quality data collection at three continuous-record monitoring sites (Pheasant Branch at Middleton, Spring Harbor Storm Sewer at Madison, and Yahara River at Windsor) continued; a new station on Yahara River at SH 113 at Madison was installed in 2001. Suspended sediment loads were computed for Spring Harbor Storm Sewer; suspended sediment and total phosphorus loads were computed for Yahara River at Windsor and Pheasant Branch for the 2001 water year. Continuous streamflow monitoring at Black Earth Creek near Black Earth was continued for the year.

Base-flow water-quality sampling was completed for Pheasant Branch at Hwy. 12 in Middleton, Token Creek near Madison, East Branch and West Branch Starkweather Creek at Madison in November 2001. Base-flow sampling will begin at a new set of four 
streams in the County for 2002. All streamflow, load, and concentration data were published in the annual data report "Water Resources Data-Wisconsin, Water Year 2001."

\section{PLANS (July 2002 to June 2003)}

Streamflow monitoring will be continued at Black Earth Creek; streamflow and water quality monitoring will be continued at the four continuous-record stations on tributaries to lake Mendota. Six base-flow water quality samples will be collected from Black Earth Creek near Cross Plains, Yahara River at Windsor, Maunesha River near Sun Prairie, and Nine Springs Creek near Madison during the calendar year (starting in spring 2002). Final data will be prepared and published in the annual data report, "Water Resources Data-Wisconsin." 


\section{WATER-QUALITY MONITORING OF FOX RIVER AND TRIBUTARIES, GREEN LAKE COUNTY}

\section{COOPERATOR: \\ Green Lake County Department of Land Conservation \\ PROJECT CHIEF: \\ Herbert S. Garn \\ LOCATION: \\ Northern Green Lake County \\ PROJECT NUMBER: \\ WI 00304 \\ PERIOD OF PROJECT: \\ October 2001 to September 2003}

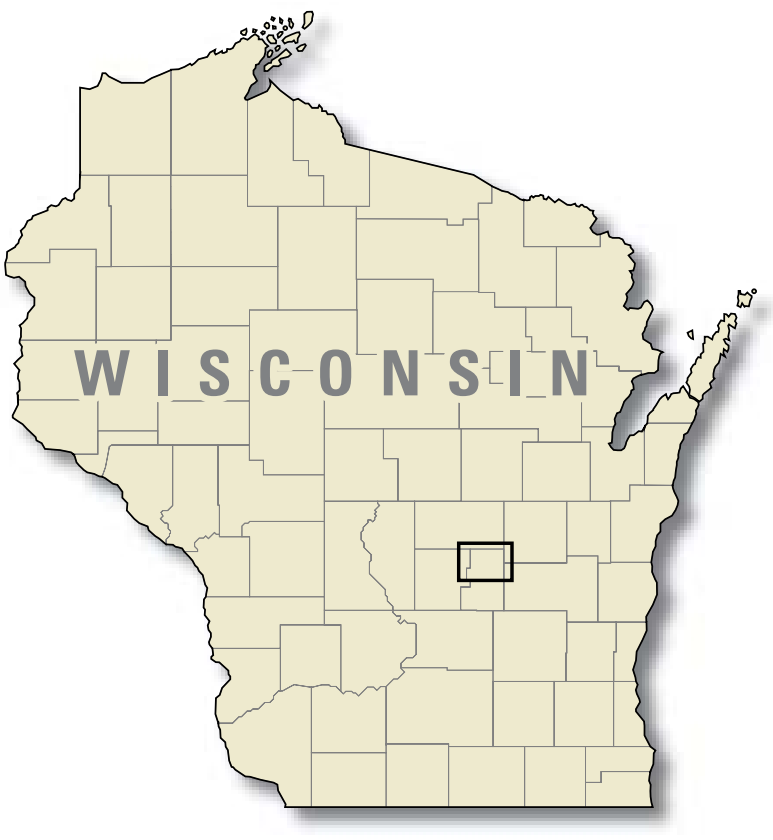

are the Mecan, White, and Puchyan Rivers and Sucker Creek. Fox River sites will be sampled six times per year and tributary sites will be sampled two times per year (once during summer low flow and once at high flow) for physical characteristics, nutrient and sediment concentrations, and bacteria. Streamflow and field water quality characteristics will be measured at each site each sampling visit. Continuous-record streamflow gaging stations on the Fox River at Princeton and at Berlin will provide information to evaluate current flow conditions relative to the long-term flow record.

\section{PROGRESS (July 2001 to June 2002)}

Fox River sites have been sampled four times and tributary sites once for the year.

\section{PLANS (July 2002 to June 2003)}

Monitoring of the sites will continue through the 2002 water year. All data will be published in the annual data report "Water Resources Data-Wisconsin, Water Year 2002." 


\section{COLLECTION OF BASIC RECORDS-SEDIMENT}

\section{COOPERATORS:}

U.S. Army Corps of Engineers

\section{PROJECT CHIEF:}

William J. Rose

\section{LOCATION:}

Statewide

PROJECT NUMBER:

WI 00400

PERIOD OF PROJECT:

March 1968-Continuing
Grant River at Burton, Wis. (Station \#05413500)

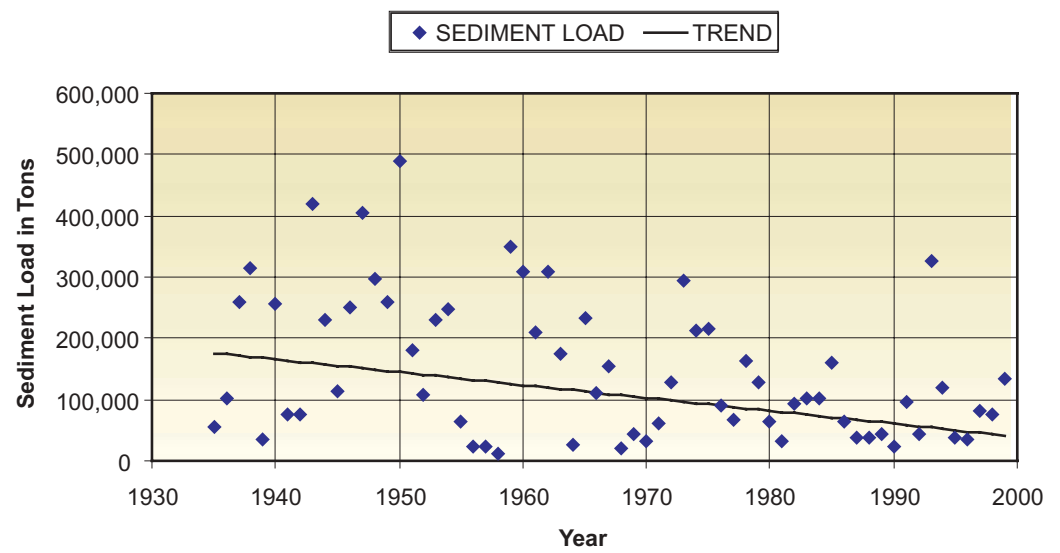

Trend analysis showing decreasing trend in annual sediment load, 1935-2001.

\section{PROBLEM}

Water-resources planning and water-quality assessment require a knowledge of the quantity and quality of sediment being transported in rivers and streams in Wisconsin.

\section{OBJECTIVE}

This project will provide sediment data for use in specific planning and action programs and will develop a database for determining trends in sediment discharge and yield. Streams will be characterized according to range of concentration and particle size of suspended sediment.

\section{APPROACH}

Sediment-monitoring stations will be operated at selected stream sites throughout the State, including sites of specific interest to cooperating agencies.

The extent of monitoring at a given site will depend on the characteristics of the basin and the needs of the cooperating agency. Some sites will be sampled manu- ally at infrequent intervals; other sites, where flow responds rapidly to precipitation, will be sampled by automatic samplers.

At sites where bedload or unmeasured sediment discharge may be a significant part of the total sediment discharge, suspended- and bed-sediment particle size will be determined from samples collected concurrently with hydraulic data. These data will be used to estimate total sediment discharge using one of several techniques such as the modified Einstein procedure.

\section{PROGRESS (July 2001 to June 2002)}

Sediment data have been collected at more than 200 stream sites in Wisconsin since 1968. All data have been published annually in the data report, "Water Resources Data-Wisconsin." The 2001 program consisted of monitoring to determine daily suspended sediment loads for Grant River at Burton. Suspendedsediment monitoring at this site has been continuous since 1978. 


\section{PLANS (July 2001 to June 2002)}

U.S. Army Corps of Engineers-Operation of the Grant River monitoring station will continue.

Efforts to secure cooperative funding to establish a long-term sediment-monitoring network will continue. About 10 sites areally distributed to sample runoff from the major geographic provinces would provide an adequate network.

\section{REPORTS}

Rose, W.J., and Graczyk, D.J., 1996, Sediment transport, particle size, and loads in North Fish Creek in Bayfield County, Wisconsin, water years 1990-91: U.S. Geological Survey Water-Resources Investigations Report 95-4222, $18 \mathrm{p}$.

Rose, W.J., 1992, Sediment transport, particle sizes, and loads in the lower reaches of the Chippewa, Black, and Wisconsin Rivers in western Wisconsin: U.S. Geological Survey Water-Resources Investigations Report 90-4124, 38 p. 


\section{COOPERATOR:}

Wisconsin Department of Natural Resources

PROJECT CHIEF:

Bernard R. Ellefson

\section{LOCATION:}

Statewide

PROJECT NUMBER:

WI 00700

PERIOD OF PROJECT:

March 1978-Continuing

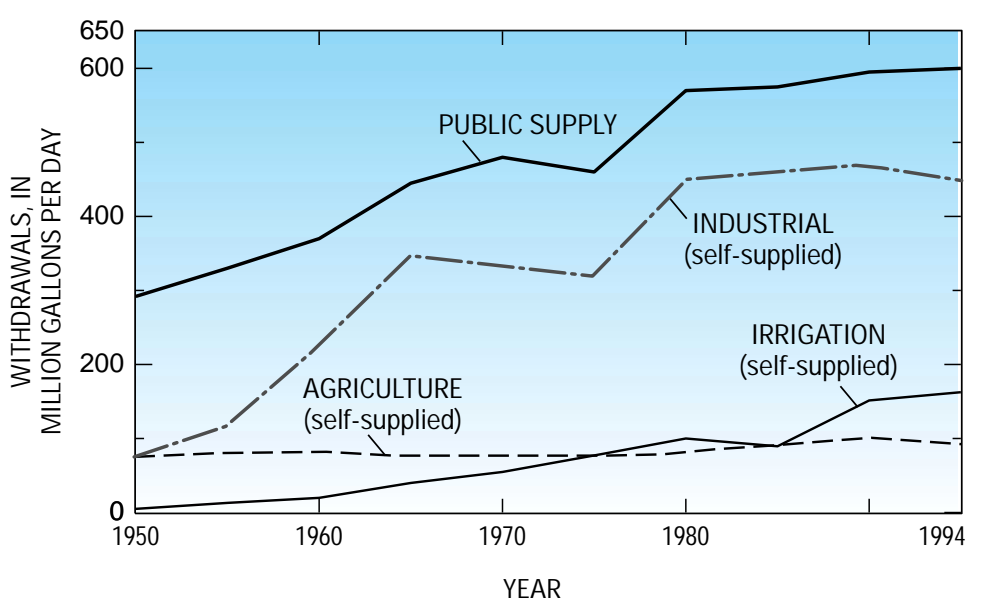

PROGRESS (July 2001 to June 2002)

The database was updated with current water-use data. These data included high capacity well data, public-supply information, and data used to estimate irrigation water use. These and other data were used to make water-use estimates for the 2000 water use summary.

\section{PLANS (July 2002 to June 2003)}

Plans include: (1) continue to update and maintain the database with current water-use data, (2) supply water-use data for water-resources studies currently being conducted in the State, and (3) publish an atlastype report, "Water Use in Wisconsin, 2000."

\section{REPORTS}

Ellefson, B.R., Fan, C.H., and Ripley, J.L., 1995, Water use in Wisconsin, 1995: U.S. Geological Survey Open-File Report 97-356, 1 sheet, scale 1:5,000,000. 
Ellefson, B.R., Sabin, T.J., and Krohelski, J.T., 1993, Water use in Wisconsin, 1990: U.S. Geological Survey Open-File Report 93-118, 1 sheet, scale 1:5,000,000.

Ellefson, B.R., Rury, K.S., and Krohelski, J.T., 1988, Wateruse in Wisconsin, 1985: U.S. Geological Survey OpenFile Report 87-699, 1 sheet, scale 1:5,000,000.

U.S. Geological Survey, 1990, National Water Summary, 1987- Hydrologic events and water supply and use: U.S. Geological Survey Water-Supply Paper 2350, $553 \mathrm{p}$.
Krohelski, J.T., Ellefson, B.R., and Storlie, C.A., 1987, Estimated use of ground water for irrigation in Wisconsin, 1984: U.S. Geological Survey Water- Resources Investigations Report 86-4079, 12 p., 1 pl.

Lawrence, C.L., and Ellefson, B.R., 1984, Public-supply pumpage in Wisconsin, by aquifer: U.S. Geological Survey Open-File Report 83-931, 40 p.

1982, Water use in Wisconsin, 1979: U.S. Geological Survey Open-File Report 82-444, 98 p. 


\section{MENOMINEE TRACE-ELEMENT MONITORING}

\begin{tabular}{|l|}
\hline COOPERATOR: \\
Menominee Indian Tribe of \\
Wisconsin \\
PROJECT CHIEF: \\
Herbert S. Garn \\
LOCATION: \\
Menominee Indian Reservation \\
PROJECT NUMBER: \\
WI 12301 \\
PERIOD OF PROJECT: \\
March 1996 to September 2001 \\
\hline
\end{tabular}

\section{PROBLEM}

Maintaining the quality and pristine nature of the Wolf River and its tributaries is extremely important to the Menominee Indian Tribe of Wisconsin (MITW) in the Upper Wolf River Basin. Information is needed to describe the current status of water quality and biotic conditions within the Reservation, and to determine the presence or absence of contaminants in major streams. Several years of data are available from a recently-completed study at a limited number of USGS sites (three) on the Wolf River near the Reservation boundaries for discharge, major ions and nutrients (1986-98), trace metals (1995-98), organics, and aquatic communities. Samplings were conducted for concentrations in water and for trace metals in water, fish livers, aquatic invertebrates, and streambed sediment. No similar comparative data exist for the major streams tributary to the Wolf River or other headwater streams originating and flowing out of the Reservation. A historical database for other streams within the Menominee Indian Reservation is needed to evaluate present conditions and provide a baseline from which changes in conditions may be determined.

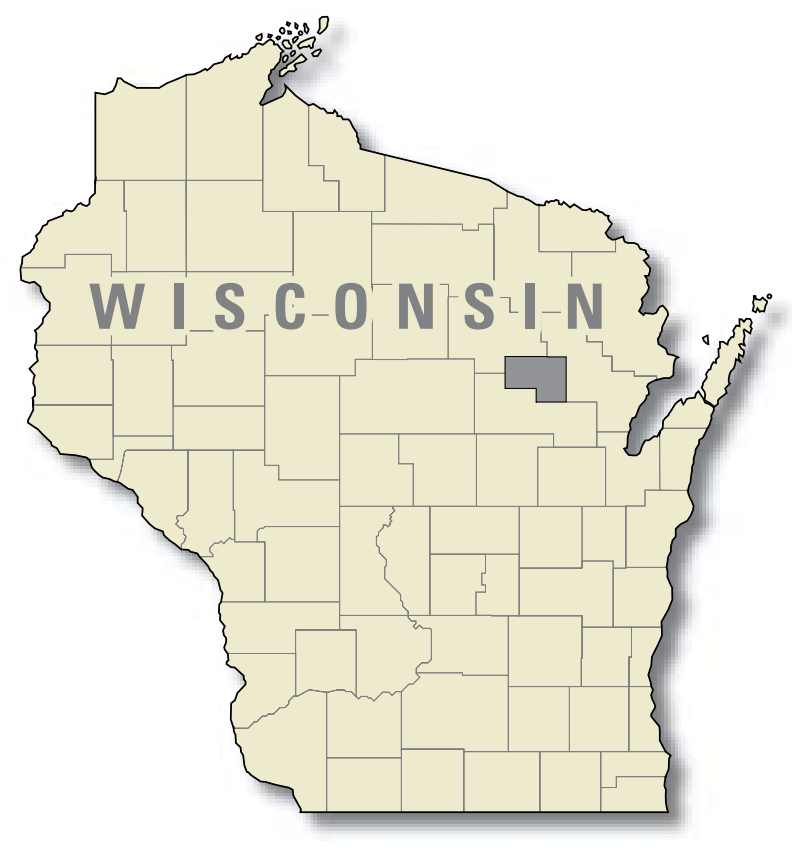

\section{OBJECTIVE}

The primary objective of the monitoring is to establish data at a network of stations throughout the Reservation that will be useful for characterizing existing water-quality conditions, developing water-quality and watershed-management plans, and helping conserve and protect ambient conditions and ecosystems of the Reservation. Specific objectives are to: (1) determine physical properties and concentrations of chemical constituents in water-column samples of all major streams on the Reservation, and (2) quantify and characterize benthic invertebrate communities at the selected sample sites as an additional indicator of water-quality and environmental conditions.

\section{APPROACH \\ Water sampling will be conducted to determine physical properties, major ion, and nutrient concentra- tions at two USGS sampling sites on the Wolf River plus 10 new sites on major tributaries to the Wolf River and other streams entering or leaving the reservation. Water-sampling frequency at each of the sites will be}


roughly quarterly beginning in October 2000 plus one synoptic sample during high-flow conditions, to yield five samples per site. Pesticide samples will be collected at three sites each sampling time. Sampling will be conducted using standard protocols of the USGS National Water Quality Assessment (NAWQA) program. Streamflow data will be collected at the USGS gaging station at Langlade.

Biological sampling for benthic macro invertebrates will be done at all sites using a fixed-effort qualitative sampling of all available habitats ("multihabitat") to provide a single composite sample. Biological sampling will be conducted once in the fall 2000 at low flow. All sample analyses will be performed by the USGS National Water Quality Laboratory.

\section{PROGRESS (July 2001 to June 2002)}

Water and benthic macroinvertebrate sampling were completed for the year. The streamflow gaging station at Langlade was operated for the year. Waterquality data and discharge data were published in the report, "Water Resources Data-Wisconsin, Water Year 2001." A summary of the benthic macroinvertebrate data was submitted to the tribe.

\section{PLANS (July 2002 to June 2003)}

Project completed.

\section{REPORTS}

Garn, H.S., Scudder, B.C., Richards, K.D., and Sullivan, D.J., Characteristics of water, sediment, and benthic communities of the Wolf River, Menominee Indian Reservation, Wisconsin, 1986-98: U.S. Geological Survey WaterResources Investigations Report 01-4019, 54 p. 


\section{Mission}

Evaluation monitoring provides critical information to the WDNR's nonpoint section to help formulate watershed management plans and evaluate the effectiveness of these plans. The monitoring also provides a unique, comprehensive data set of interest to the nonpoint research community at large. The objectives of the evaluation monitoring team are: (1) to efficiently manage projects from the conception and proposal stage to management and operation resulting in thoughtful and timely products from data summaries to published reports, and (2) to maintain a sufficient amount of funding and challenging work for the entire team. Through these objectives, it is our intent to continuously evolve data collection and analysis techniques, plan for future projects, enhance the skills and evolve data collection and analysis techniques, enhance the skills and growth of individual team members, and maintain a positive relationship with the cooperator.

\section{Team Members}

Judy A. Horwatich, Hydraulic Engineer Peter E. Hughes, Hydrologist

John F. Walker, Research Hydrologist/Engineering Steve R. Corsi, Hydrologist

Dave J. Graczyk, Hydrologist/Forestry Todd D. Stuntebeck, Physical Scientist Troy D. Rutter, Hydrologic Technician Ellen J. Considine, Student Trainee (Hydrology)

Eric G. Booth, Hydrologic Technician Laura E. Wagner, Hydrologic Technician Mari Danz, Hydrologic Technician

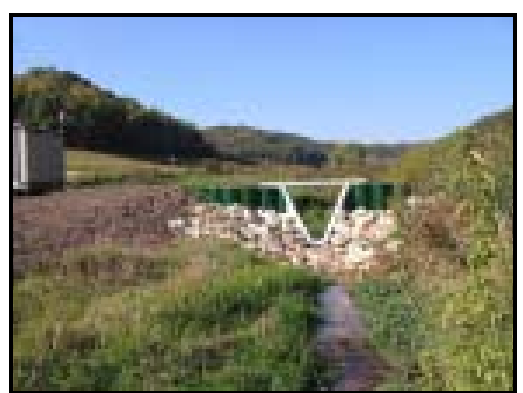

" $H$ " Flume for monitoring discharge at Discovery Farms in Buffalo County, Wisconsin.

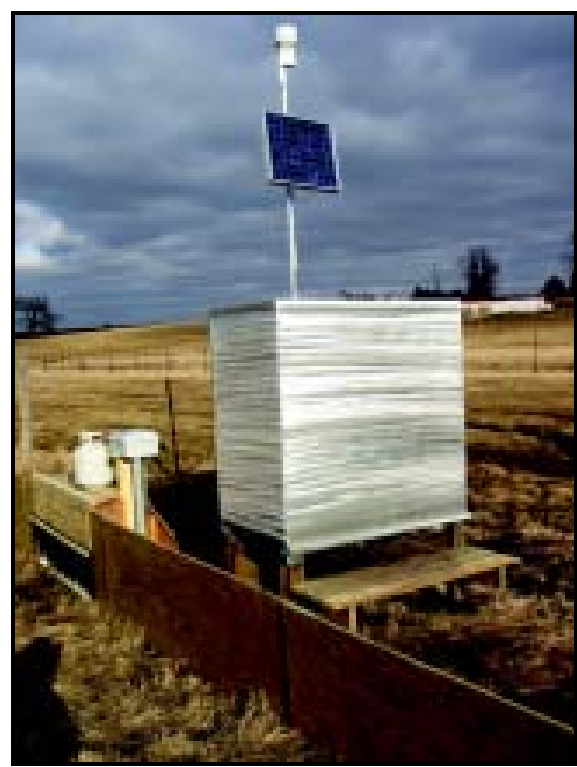

Gaging station at the University of Wisconsin Research farm near Platteville, Wisconsin. 


\section{PROJECTS}

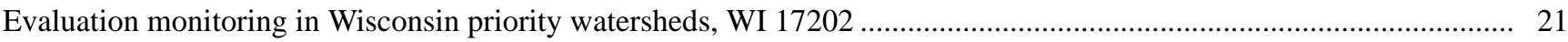

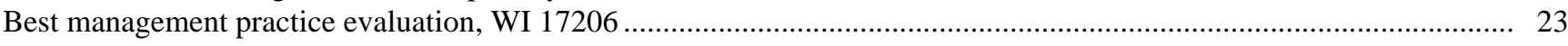

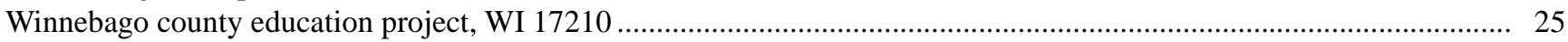

Influences of riparian corridors on the in-stream habitat, fish, and macroinvertebrate communities for small

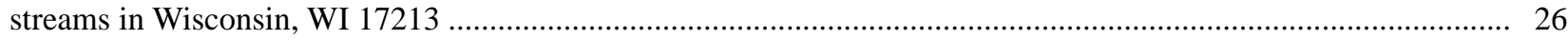

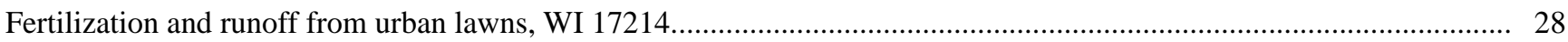

Impact of phosphorus and nitrogen concentrations on the biological integrity of Wisconsin streams, WI 17223 ............. 30

Hydrology and water-quality impacts of different pasture management practices in southwestern Wisconsin,

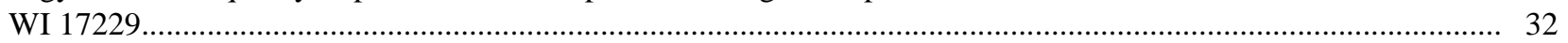

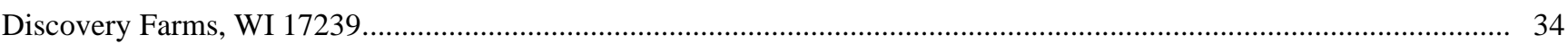

Quantification of constituent loads from farm fields at the Pioneer Farms in Wisconsin, WI 17240 ............................... 36 


\section{EVALUATION MONITORING IN WISCONSIN PRIORITY WATERSHEDS}

\begin{tabular}{l} 
COOPERATOR: \\
Wisconsin Department of Natural \\
$\quad$ Resources \\
PROJECT CHIEFS: \\
David J. Graczyk \\
Steven R. Corsi \\
Judy A. Horwatich \\
LOCATION: \\
Priority watersheds in Brown, \\
Buffalo, and Sheboygan Counties \\
PROJECT NUMBER: \\
WI 17202 \\
PERIOD OF PROJECT: \\
October 1990-Continuing \\
\hline
\end{tabular}

\section{PROBLEM}

An evaluation strategy is needed to assess the effectiveness of nonpoint-source pollution control measures in priority watersheds. Specifically, research is needed to determine the impact of management practices stream-water quality and biology. Several techniques need to be developed and/or refined, such as detecting trends in stream-water chemistry, sampling of fish and fish habitat, relation between fish/fish habitat and changes resulting from watershed management practices, and use of habitat models for determining impact of watershed management on fish populations.

\section{OBJECTIVE}

The overall objective of this project is to determine the trends in water quality for four sites during and after implementation of improved land-management practices in three priority watersheds and to use GIS to understand changes in land use/land cover.

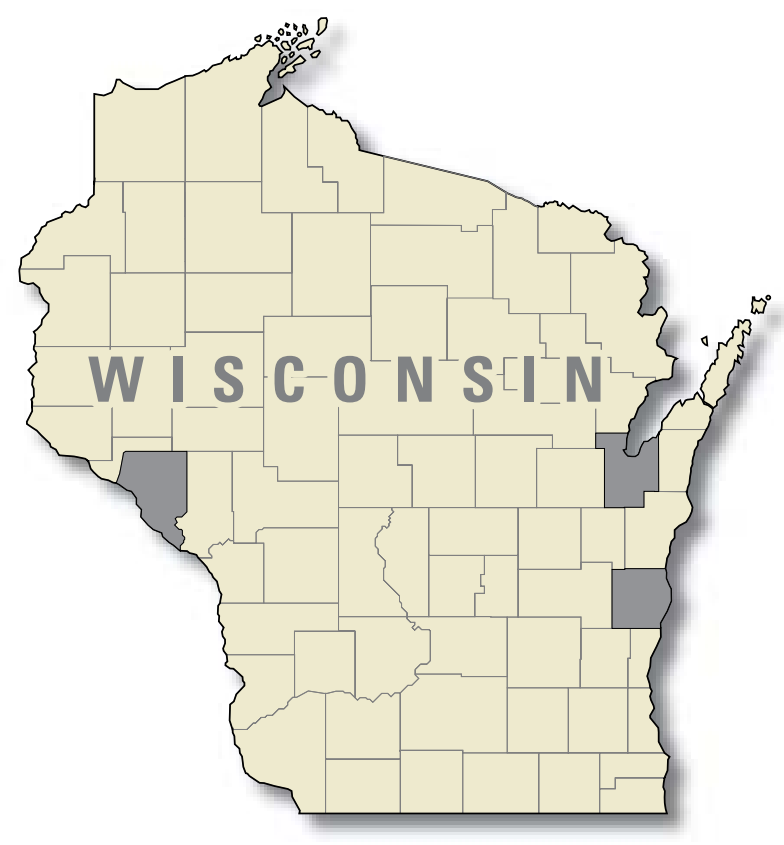

\section{APPROACH}

Post-practice implementation monitoring will be done for Otter, Bower, Eagle, and Joos Valley Creeks, which are in the Sheboygan River, East River, and Waumandee River Priority Watershed Projects, respectively. The pre-practice implementation is complete for all of these sites. Continuous-record streamflow, water temperature, and dissolved-oxygen gaging stations were installed at each stream site. Water-quality samples will be collected during events and low flows and analyzed for selected constituents. Land-use inventories will be taken each year to help determine the cause of any changes in water quality. Monitoring at Bower Creek will be initiated again during the summer of 2003.

\section{PROGRESS (July 2001 to June 2002)}

Post-practice implementation monitoring for Otter Creek has been ongoing for two years. Water-quality loads were calculated for selected parameters and storm periods. All the data were summarized and published in 
the report "Water-Resources Data-Wisconsin." Landuse inventories were completed for each basin.

\section{PLANS (July 2002 to June 2003)}

Streamflow and water-quality monitoring will be continued at Otter Creek site through September 2002. Eagle and Joos Valley Creeks will be monitored for streamflow and water quality beginning in October 2002. At Otter Creek, water-quality samples will be collected weekly during the period of July-October. For other sites, water-quality samples are collected biweekly from April through October, and monthly from December through March. Samples will be collected at all sites during runoff periods. Land use will be updated for each basin. Bower Creek site installation and trouble shooting will begin in summer 2003 and be ready for monitoring the following year. Water-quality loads for selected parameters and storm periods will be calculated and compared to data collected in previous years. The data will be analyzed to determine if there are any apparent trends in water quality during implementation of best management plans. A report will be published on post monitoring of Brewery and Garfoot Creeks in the Black Earth Creek Priority Watershed Project.

\section{REPORTS}

Walker, J.F., Graczyk, D.J., Corsi, S.R., Wierl, J.A., and Owens, D.W., 2001, Evaluation of nonpoint-source contamination, Wisconsin — water year 1999: U.S. Geological Survey Open-File Report 01-105, 37 p.

Wierl, J.A., Giddings, E.M., and Bannerman, R.T., 1998, Evaluation of a method for comparing phosphorus loads from barnyards and croplands in Otter Creek watershed, Wisconsin: U.S. Geological Survey Fact Sheet 168-98, $4 \mathrm{p}$.

Corsi, S.R., Graczyk, D.J., Owens, D.W., and Bannerman, R.T., 1997, Unit-area loads of suspended sediment, suspended solids, and total phosphorus from small watersheds in Wisconsin: U.S. Geological Survey Fact Sheet 195-97, $4 \mathrm{p}$.

Rappold, K.F., Wierl, J.A., and Amerson, F.U., 1997, Watershed characteristics and land management in the nonpoint-source evaluation monitoring watersheds in Wisconsin: U.S. Geological Survey Open-File Report 97-119, $39 \mathrm{p}$.

Wierl, J.A., Rappold, K.F., and Amerson, F.U., 1996, Summary of the land-use inventory for the nonpoint-source evaluation monitoring watershed in Wisconsin: U.S. Geological Survey Open-File Report 96-123, 23 p.

Greb, S.R., and Graczyk, D.J., 1995, Frequency-duration analysis of dissolved-oxygen concentrations in two southwestern Wisconsin streams: Water Resources Bulletin, v. 31, no. 3, p. 431-438. 
BEST MANAGEMENT PRACTICE EVALUATION

\begin{tabular}{|l|}
\hline COOPERATOR: \\
Wisconsin Department of Natural \\
Resources \\
PROJECT CHIEF: \\
John F. Walker \\
LOCATION: \\
Statewide \\
PROJECT NUMBER: \\
WI 17206 \\
PERIOD OF PROJECT: \\
October 1989 to September 2002 \\
\hline
\end{tabular}

\section{PROBLEM}

To date, the effectiveness of best management practices (BMPs) in Wisconsin has not been determined. The natural variability of water-quality data complicates the detection of changes due to BMP implementation. Research is needed to identify techniques for detecting changes due to BMP implementation and applying the techniques to before and after data.

\section{OBJECTIVE}

The objective is to investigate statistical analysis techniques for assessing trends in water quality due to BMP implementation. The effectiveness of BMPs in several rural basins in Wisconsin will be determined using the identified statistical techniques.

\section{APPROACH}

A comprehensive literature search will be conducted to identify viable statistical analysis techniques and needs for method modification or development. Data for several rural and urban basins in other states

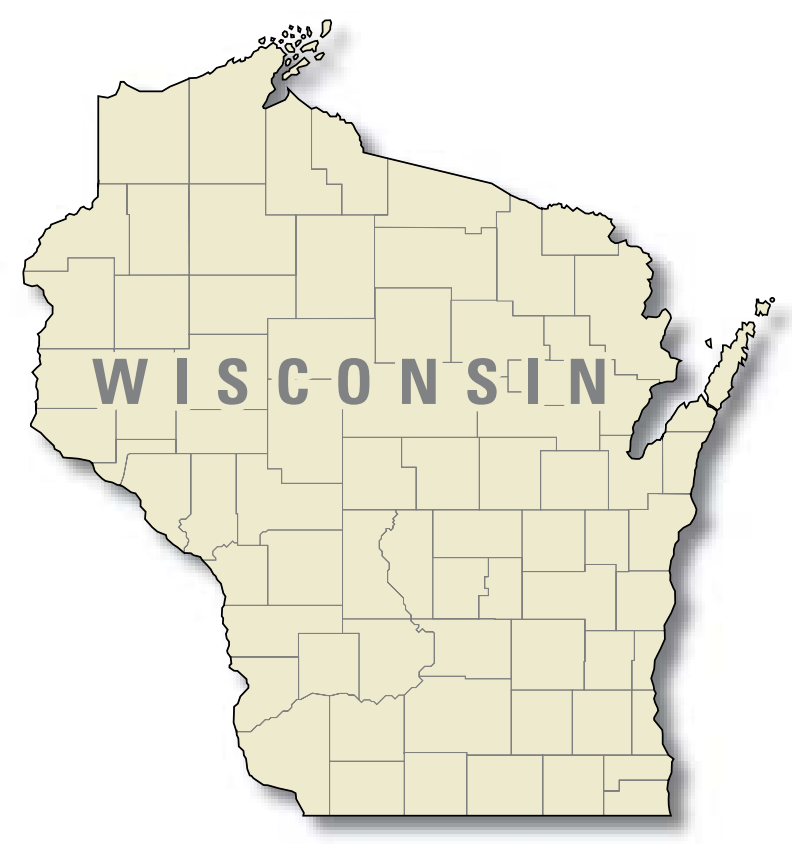

will be compiled and used to test the selected techniques. Storm loads of total-suspended solids and total phosphorus will be computed and used along with rainfall data and land-use information to assess the effectiveness of the BMPs in several basins in Wisconsin.

\section{PROGRESS (July 2001 to June 2002)}

Published annual report describing results of statistical analysis for data collected through the 1999 water year. Completed draft of report describing final results for the Black Earth Creek watershed.

\section{PLANS (July 2002 to June 2003)}

A Water-Resources Investigation Report will be published.

\section{REPORTS}

Walker, J.F., Graczyk, D.J., Corsi, S.R., Wierl, J.A., and Owens, D.W., 2001, Evaluation of nonpoint-source contamination, Wisconsin: water year 1999, U.S: Geological Survey Open-File Report 01-105, 37 p. 
Wierl, J.A., Giddings, E.M.P., and Bannerman, R.T., 1998, Evaluation of a method for comparing phosphorus loads from barnyards and croplands in Otter Creek Watershed, Wisconsin: U.S. Geological Survey Fact Sheet FS-168-98, 4 p.

Owens, D.W., Corsi, S.R., and Rappold, K.F., 1997, Evaluation of nonpoint-source contamination, Wisconsin: selected data for water year 1995: U.S. Geological Survey Open-File Report 96-661 A, 41 p.

Corsi, S.R., Graczyk, D.J., Owens, D.W. and Bannerman, R.T., 1997, Unit-area loads of suspended sediment, suspended solids, and total phosphorus from small watersheds in Wisconsin: U.S. Geological Survey Fact Sheet FS-195-97, 4 p.

Walker, J.F., Graczyk, D.J., Corsi, S.R., Owens, D.W., and Wierl, J.A., 1995, Evaluation of nonpoint-source contamination, Wisconsin: land use and best management practices inventory, selected streamwater-quality data, urban-watershed quality assurance and quality control, constituent loads in rural streams, and snowmelt-runoff analysis, water year 1994: U.S. Geological Survey Open- File Report 95-320, 21 p.
Corsi, S.R., Walker, J.F., Graczyk, D.J., Greb, S.R., Owens, D.W., and Rappold, K.F., 1995, Evaluation of nonpointsource contamination, Wisconsin: selected streamwaterquality data, land-use and best-management practices inventory, and quality assurance and quality control, water year 1993: U.S. Geological Survey Open-File Report 94-707, $57 \mathrm{p}$.

Walker, J.F., 1994, Statistical techniques for assessing waterquality effects of BMPs, ASCE J. of Irrigation and Drainage Engineering, v. 120, no. 2, p. 334-347.

Walker, J.F., and Graczyk, D.J., 1993, Preliminary evaluation of effects of best management practices in the Black Earth Creek, Wisconsin, priority watershed: Water Science and Technology, v. 28, no. 3-5, p. 539-548.

Walker, J.F., 1993, Techniques for detecting effects of urban and rural land-use practices on stream-water chemistry in selected watersheds in Texas, Minnesota, and Illinois: U.S. Geological Survey Open-File Report 93-130, 16 p.

Graczyk, D.J., Walker, J.F., Greb, S.R., Corsi, S.R., Owens, D.W., 1993, Evaluation of nonpoint-source contamination, Wisconsin: Selected data for 1992 water year: U.S. Geological Survey Open-File Report 93-630, 48 p. 


\begin{tabular}{|l|}
\hline COOPERATOR: \\
Winnebago County Land and \\
Water Conservation District \\
PROJECT CHIEF: \\
Judy A. Horwatich \\
LOCATION: \\
Statewide \\
PROJECT NUMBER: \\
WI 17210 \\
PERIOD OF PROJECT: \\
May 2001 to May 2002 \\
\hline
\end{tabular}

\section{PROBLEM}

The city of Neenah is urbanizing in the Little Lake Butte Des Morts watershed and the Winnebago County Land and Water Conservation District is concerned about the effect this will have on the lake's water quality. The county is cooperating with the University of Wisconsin Extension to collect in-stream grab samples for the identification of runoff pollutants. This sampling has been a community effort by students and local volunteers for educational purposes. This project will help quantify their collected data.

\section{OBJECTIVE}

To monitor a stream that is representative of the Little Lake Butte Des Morts watershed. Also to provide data that could be used to calibrate a water-quality model.

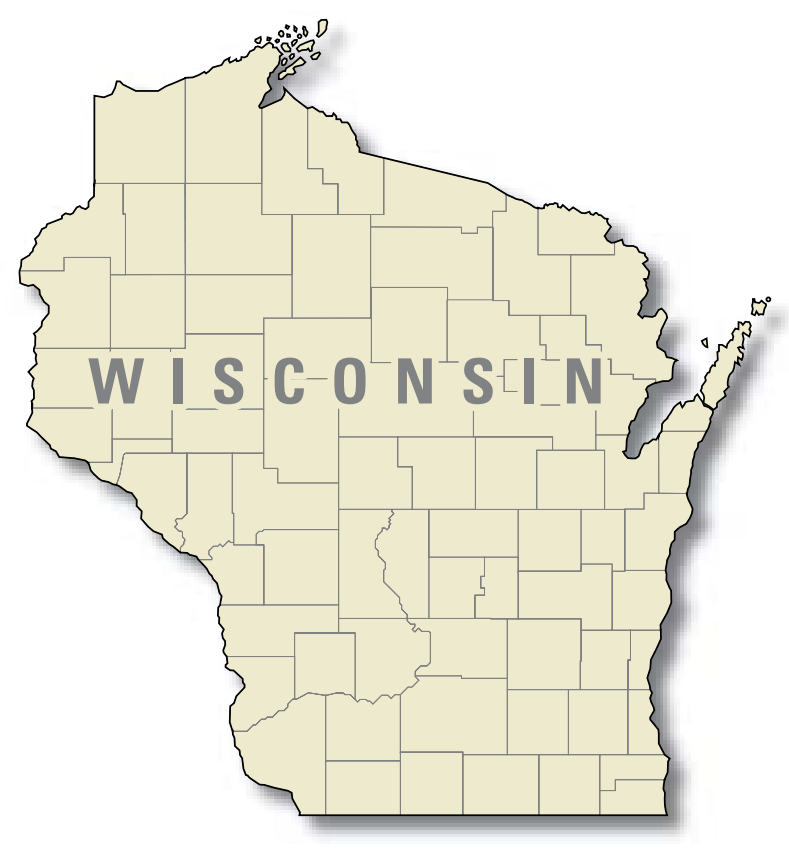

\begin{abstract}
APPROACH
Install a continuous recording stream flow gaging station at one site. Stormwater runoff samples will be collected during rainfall events. Discharge measurements will be made every 4 to 6 weeks and more frequently during high flows to define a stage/discharge relationship at the site.
\end{abstract}

\section{PROGRESS (May 2001 to April 2002)} pleted.

Water quality monitoring of the site has been com-

\section{PLANS (April 2002 to June 2002)}

Continuous stream flow monitoring and discharge measurements will be made until the end of June. An analysis of the quantity and quality of the station needs to be completed. 


\section{INFLUENCES OF RIPARIAN CORRIDORS ON THE IN-STREAM HABITAT, FISH, AND MACROINVERTEBRATE COMMUNITIES FOR SMALL STREAMS IN WISCONSIN}

\section{COOPERATOR:}

Wisconsin Department of Natural Resources

PROJECT CHIEF:

Judy A. Horwatich

\section{LOCATION:}

Statewide

PROJECT NUMBER:

WI 17213

\section{PERIOD OF PROJECT:}

July 2001-Continuing

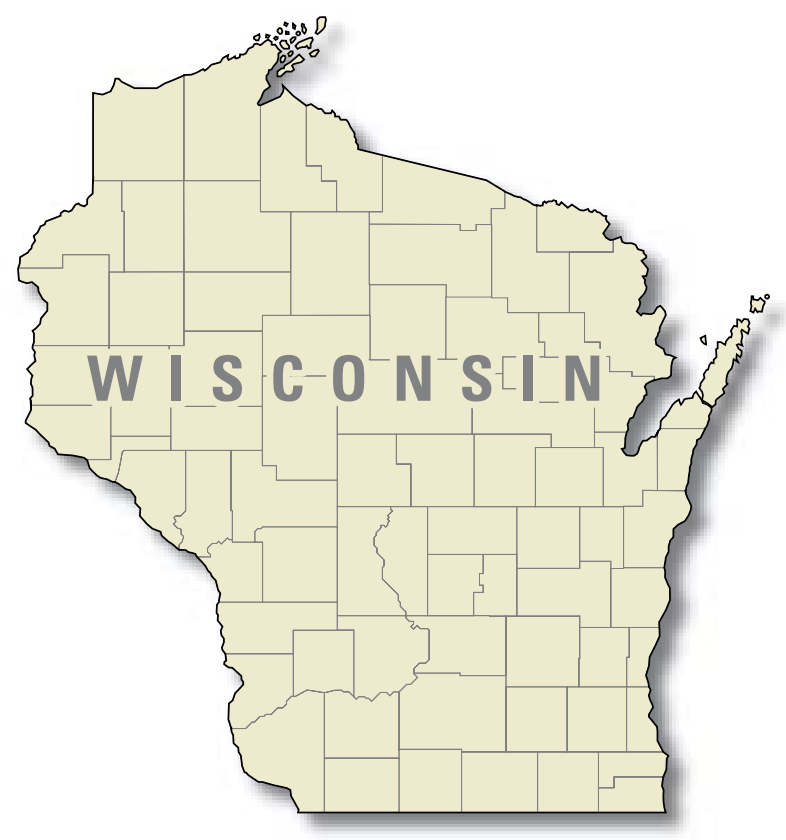

on in-stream habitat and fish and macroinvertebrate communities, and (3) identify the influence of the continuity of an undisturbed riparian corridor to in-stream habitat, and fish and macroinvertebrate communities.

\section{APPROACH}

A subset of streams will be selected for this project from 160 small and 80 medium streams that are being sampled as part of Nutrient Impacts on Streams, a cooperative project between the USGS and WDNR. The first step will be to categorize all streams into four groups, based on the ecoregion (Omernik, 1987) in which they are located. Eighty sites will be selected for this study based on availability of digital orthophotography, similarities of slope and surficial deposits within ecoregions, and preliminary assessments of riparian corridor land cover using the WISCLAND satellite-derived land cover data. For the selected watersheds, riparian corridor land cover will be interpreted from digital and orthophotography. Streams within each ecoregion will be categorized into four groups based on the width of an undisturbed riparian corridor (narrow versus wide) and 
distance upstream, from the sampling site to an undisturbed riparian corridor (near versus far). Multi-variate statistics will be used to look at relations between riparian-corridor width, proximity of an undisturbed riparian corridor to the sampling site, and continuity of an undisturbed riparian corridor versus in-stream habitat, and fish and macroinvertebrate communities.

\section{PROGRESS (July 2001 to June 2002)}

The 160 sampling sites have been selected for the Nutrient Impacts on Streams study. Eighty new sites on larger streams were selected. A preliminary design has been developed for the riparian corridor study based on the objectives and the type and location of the nutrient impact sites.

\section{PLANS (July 2001 to June 2002)}

Forty sites will be selected for this study based on availability of data and preliminary analysis of ancillary data, including ecoregion, watershed slope, surficial deposits, and land cover. Stream networks and riparian corridor land cover will be interpreted from digital orthophotography and summary statistics will be calculated for riparian-corridor width, proximity of the sampling site to an upstream undisturbed riparian corridor, and continuity of an undisturbed riparian corridor.

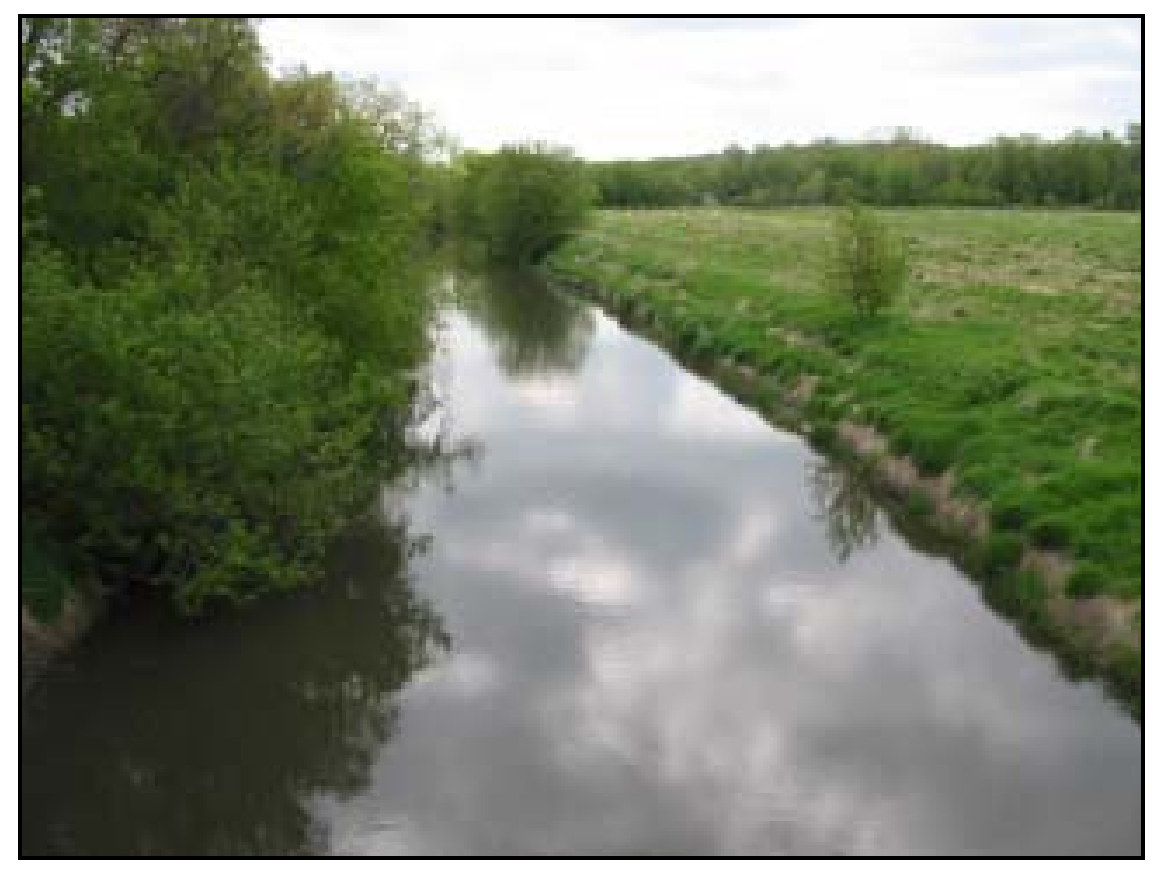

Typical stream buffering in Wisconsin. 


\section{FERTILIZATION AND RUNOFF FROM URBAN LAWNS}

\author{
COOPERATOR: \\ Wisconsin Department of Natural \\ Resources \\ PROJECT CHIEF: \\ Todd D. Stuntebeck

\section{LOCATION:} \\ Dane County \\ PROJECT NUMBER: \\ WI 17214 \\ PERIOD OF PROJECT: \\ March 1994-Continuing
}

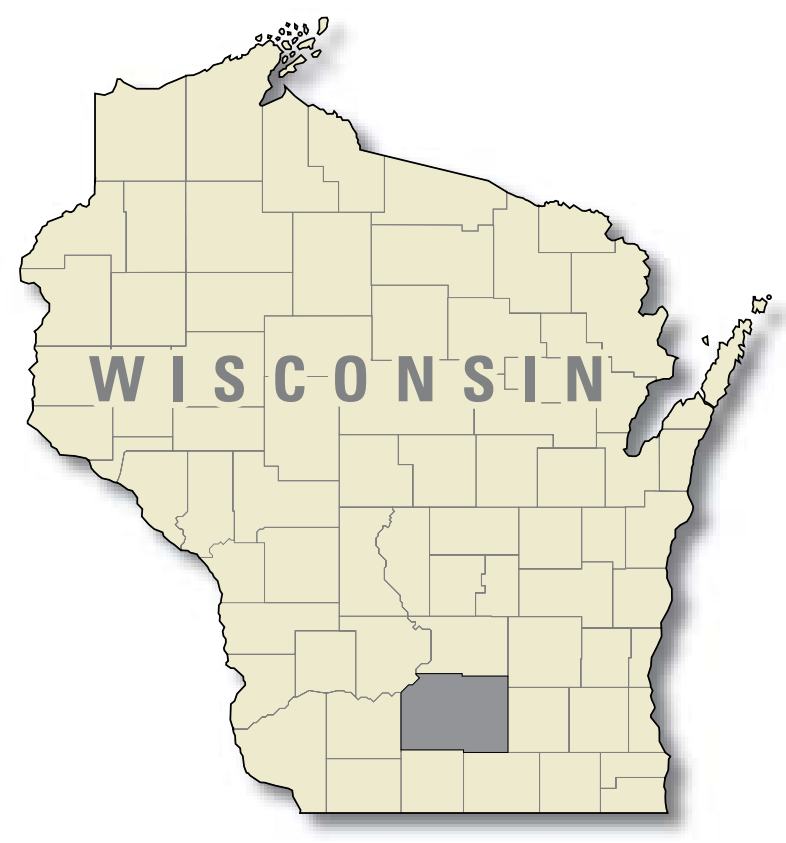

conditions of urban lawns. A better understanding of how much water runs off a typical urban lawn and under what conditions will help watershed investigators to improve their ability to predict the impacts of management decisions.

\section{OBJECTIVE}

Objectives are to: (1) determine if the concentrations of total phosphorus, dissolved phosphorus, suspended solids, and total solids in runoff from fertilized lawns are different than concentrations from lawns that are not fertilized, (2) use the concentration data in an existing Source Area Loading and Management Model (SLAMM) model to estimate phosphorus loads entering Lake Wingra from both fertilized and non-fertilized lawns, (3) determine the potential reduction in phosphorus loads to Lake Wingra by restricting fertilizer use in the watershed to phosphorus-free brands, (4) obtain rainfall and runoff data with site characteristic data for lawns from different soil types, and (5) use the concentration/runoff information to make improvements to the SLAMM model. 


\section{APPROACH}

Lake Wingra Lawn Fertilization Study (Waterquality samplers only) — Lawn-runoff samples were collected from 30 water-quality samplers between May 1999 and September 2001. Fifteen of the samplers were located in lawns that were fertilized, and the other 15 were in lawns that were not fertilized. Samples were analyzed for total phosphorus, dissolved phosphorus, total solids, and suspended solids. Two tipping-bucket rain gages and three bulk-precipitation gages were located within the Lake Wingra watershed. Site characteristic data such as soil type and chemical contents, grass density, lawn slope, soil compaction, and infiltration capacity were measured for each of the 30 lawns. Several small experiments were conducted in order to better understand what happens when the bottles overfill and how much phosphorus is likely to come from grass clippings only.

Lawn Runoff Study (Volume/QW samplers)— Runoff volumes are being measured and water-quality samples are being collected for five specialized samplers in the Lake Wingra watershed. In addition to the runoff data, several explanatory variables will be measured for each lawn, including grass density, lawn slope, soil compaction, and infiltration rate. Using statistical regression techniques, an equation will be

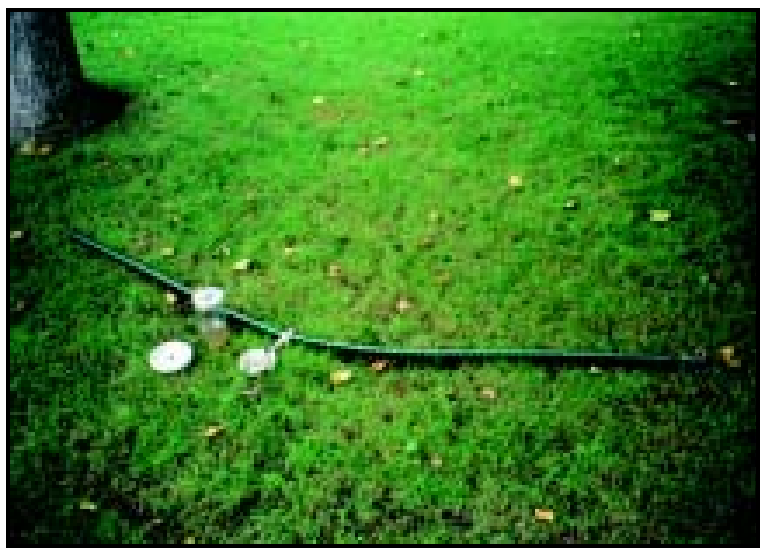

A typical water-quality sampler site showing lawn edging and sample bottle. developed to help explain much of the variability in lawn runoff volumes. Sites will be operated through September 2003. Ten additional sites are planned to be added-five sites with sandy soil and five sites with clayey soil- to explain runoff characteristics in different soil regimes. We expect installation of the new sites starting in October 2002.

\section{PROGRESS (July 2001 to June 2002)}

Nearly 1,200 sample concentrations have been obtained for 42 runoff periods since May 1999. Soil samples have been collected and analyzed at two depths for each of the 30 lawns. Five volume samplers have been installed and operated on silt-loam soils. Collectively, these five samplers have recorded runoff data and collected water-quality data for over a dozen snowmelt and rainfall-runoff events.

\section{PLANS (July 2002 to June 2003)}

All of the data from the initial lawn-runoff study (water-quality samplers only) will be compiled and analyzed. A fact sheet describing the findings will be published. Ten additional lawn volume/QW samplers will be installed in sandy and clayey soils. A Fact Sheet will be published explaining the Lake Wingra Fertilization Study.

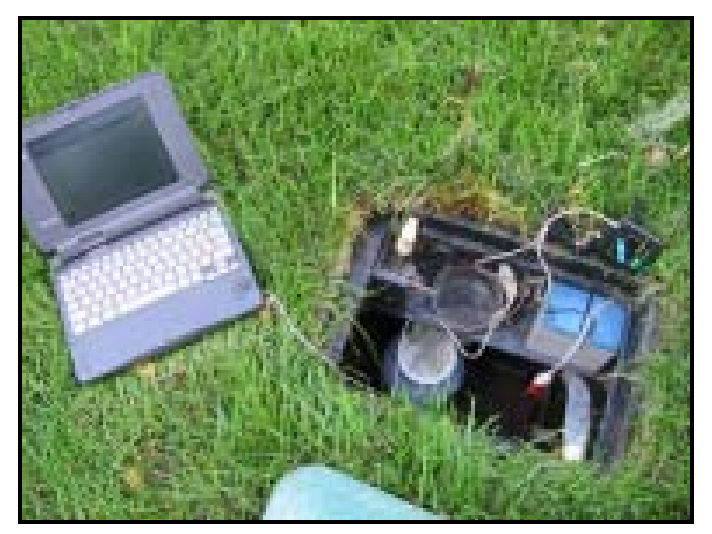

Instrumentation for the volume/water-quality sampler showing tipping bucket, cone splitter, sample bottle, and electronic datalogger. 


\section{IMPACT OF PHOSPHORUS AND NITROGEN CONCENTRATIONS ON THE BIOLOGICAL INTEGRITY OF WISCONSIN STREAMS}

\begin{tabular}{|l|}
\hline COOPERATOR: \\
Wisconsin Department of Natural \\
Resources \\
PROJECT CHIEFS: \\
David J. Graczyk \\
Dale M. Robertson \\
LOCATION: \\
Statewide \\
PROJECT NUMBER: \\
WI 17223 \\
PERIOD OF PROJECT: \\
March 2001 to June 2004 \\
\hline
\end{tabular}

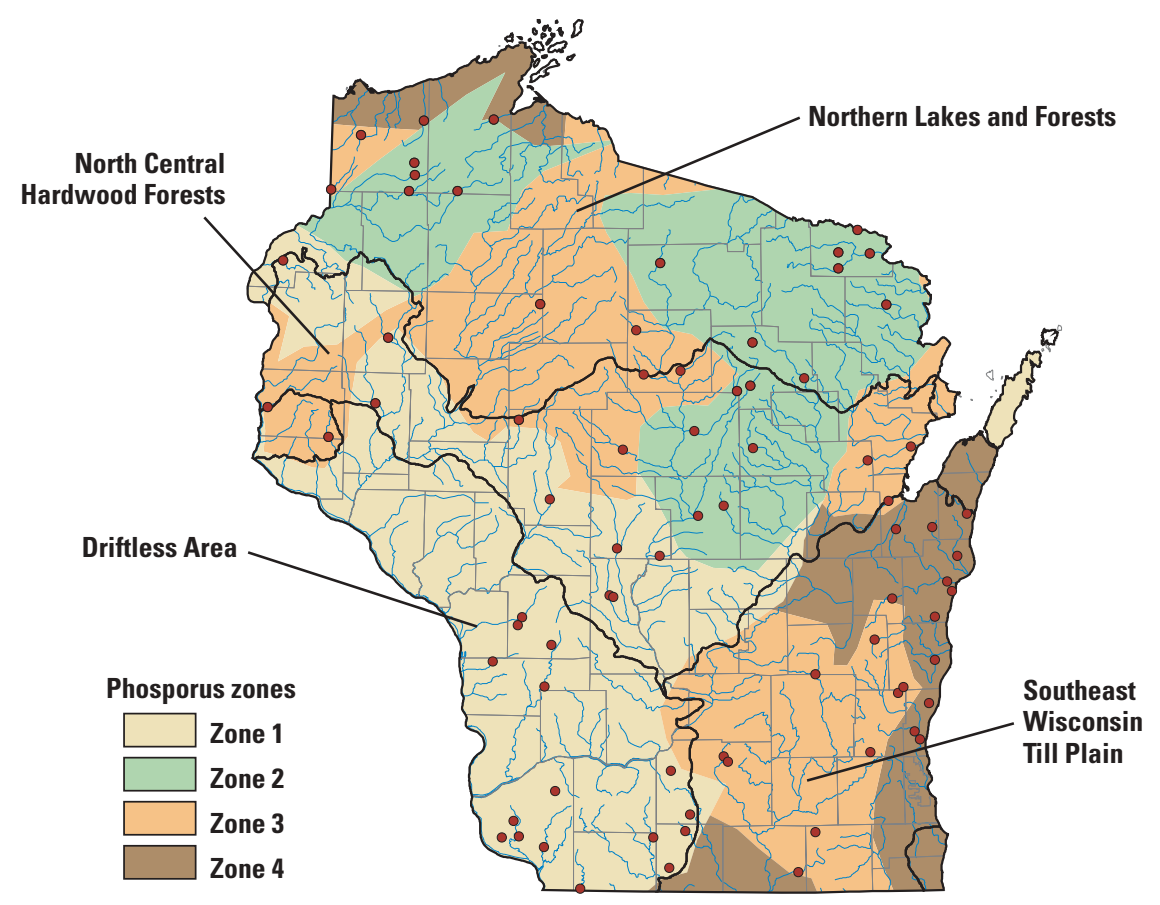

\section{PROBLEM}

Excessive nutrient (primarily phosphorus and nitrogen) loss from the watershed is frequently associated with water-quality problems in Wisconsin's water bodies. The implementation of the WDNR's proposed agricultural performance standards and prohibitions should decrease the risk of excessive nutrient loss from croplands and livestock operations. Landowners would be asked to limit their amount of commercial fertilizer use and reduce the impacts of manure storage and spreading. Implementation of TMDLs and the enforcement of phosphorus criteria would also reduce the problems caused by nutrients. The expected water-quality improvements due to the application of agricultural performance standards may vary due to possible differences in nutrient responses in each water body. In order to evaluate the environmental benefits of the proposed performance standards and phosphorus criteria, sufficient data need to be collected in various types of streams to define the nutrient response.

\section{OBJECTIVE}

The objectives of the project are to: (1) determine what phosphorus and nitrogen concentrations impair the biological integrity of a stream, (2) develop a database that can be used to refine the phosphorus criteria for Wisconsin streams, (3) determine how watershed characteristics affect the relations between phosphorus and nitrogen concentrations in streams and the biological integrity of the streams, and (4) improve our biological assessment of nutrient impairments by developing a nutrient index of biological integrity.

\section{APPROACH}

The approach for the project is to statistically determine significant relations exist between a stream's nutrient concentrations, biological integrity, and watershed characteristics. Multivariate statistical analyses will be used to sort out the importance of the many different variables. Since these nutrient relations are 
expected to vary with stream size and the location of the stream in the state, streams will be grouped by size, and by four nutrient ecoregions and four nutrient zones. Streams will be divided into those with smaller watersheds of 4 to 50 square kilometers, those with larger watersheds (greater than 50 square kilometers) but are wadeable, and those with larger watersheds (greater than 50 square kilometers) but are not wadeable.

The variables in the statistical analysis will include indicators of biological integrity, habitat characteristics, nutrient concentrations, and specific watershed characteristics. The biological indicators will include fish abundance and diversity, macroinvertebrate diversity, and periphyton biomass. Water samples collected from the stream will be analyzed for total phosphorus, dissolved phosphorus, nitrate, total Kjeldahl nitrogen, ammonia, turbidity, conductivity, and suspended chlorophyll $a$. Watershed characteristics will include drainage-area size, stream gradient, climate data, land use, annual runoff, surficial deposits data, soil types, soil erodability, and riparian buffer data.

Approximately 160 small streams will be monitored in the first year of the study. Approximately 80 larger wadeable streams will be monitored in the second year of the study and approximately 40 larger nonwadeable larger streams will be sampled in the third year of the study. Sites will be selected from streams where the fish community and habitat had been sampled over the last five years by the Wisconsin Department of Natural Resources and will be attempted to be equally divided among ecoregions and nutrient zones. The fish and habitat data in the wadeable streams were collected using similar protocols at all sites and the data are stored in a readily accessible database.

A total of six water-quality samples will be collected between the months of May and October at each site. Nutrient concentrations will be determined from samples collected at each stream by standard sampling methods. A flow measurement will be collected at the time of the water-quality grab sample.

\section{PROGRESS (July 2001 to June 2002)}

Samples were collected at 158 smaller streams in four ecoregions and four phosphorus zones in July through October, 2001 and in 78 larger wadeable streams in May and June, 2002. Samples were analyzed for nutrients and chlorophyll $a$. Field measurements included stream discharge, water temperature, dissolved oxygen, $\mathrm{pH}$, turbidity, conductance, and stream clarity. Most of the sites were sampled for attached algae by the Wisconsin Department of Natural Resources.

The median total phosphorus and total nitrogen concentrations for small streams in NLF ecoregion were significantly lower than those in the DFA ecoregion, which were significantly lower than those in the SWTP and NCHF ecoregions. The median total phosphorus and total nitrogen concentrations for small streams in phosphorus zone 2 were significantly less than those in phosphorus zones 1,3 , and 4 .

All data collected in 2001 were summarized and published in the report "Water Resources Data-Wisconsin, Water Year 2001."

\section{PLANS (July 2002 to June 2003)}

Samples will be collected at 78 wadeable streams with drainage basins greater than 50 square kilometers for the months of July through October. All data collected in 2002 will be summarized and published in the report "Water Resources Data-Wisconsin, Water Year 2002." 


\section{HYDROLOGY AND WATER-QUALITY IMPACTS OF DIFFERENT PASTURE MANAGEMENT PRACTICES IN SOUTHWESTERN WISCONSIN}

\section{COOPERATOR: \\ Wisconsin Department of Natural Resources \\ PROJECT CHIEF: \\ David J. Graczyk \\ LOCATION: \\ Sauk County \\ PROJECT NUMBER: \\ WI 17229 \\ PERIOD OF PROJECT: \\ October 1997 to September 2003}

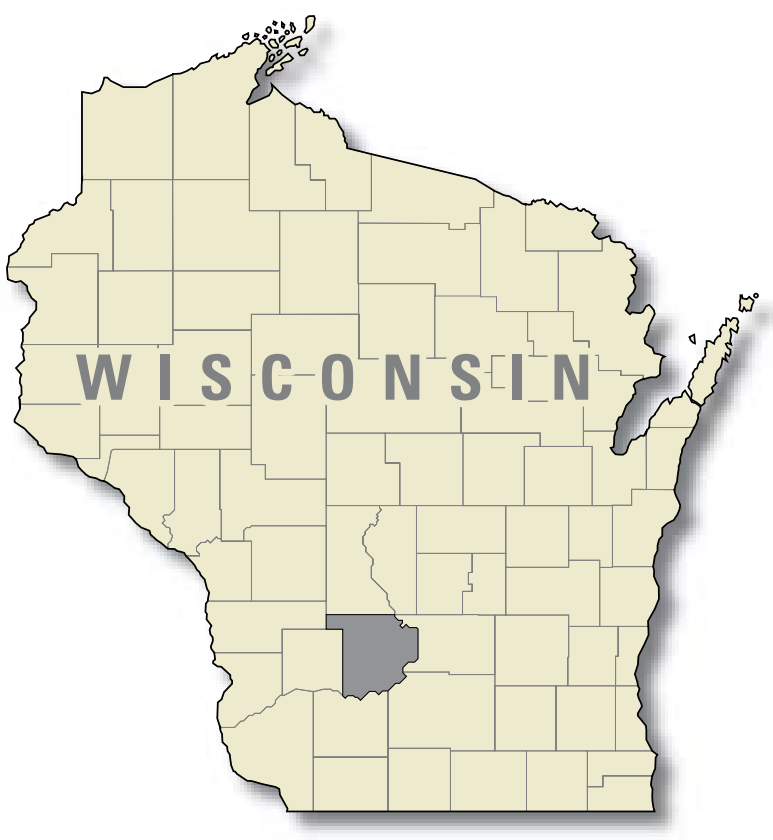

\section{OBJECTIVE}

The overall objective of this study is to determine differences in quantity and quality of surface-water runoff from three different pasture-management strategies. These strategies consist of a variety of practices which are available to pasture managers, both during the growing and dormant seasons. Combinations of management practices have been chosen to represent commonly used strategies. In addition to examining differences in overall management strategies, differences related to individual seasonal practices will be determined. A secondary objective will be to determine a water budget for each pasture. The water budget will be determined by measuring surface-water runoff and precipitation. Evaporation and transpiration will be estimated by using empirical equations and ground-water flow will be estimated as a residual.

\section{APPROACH}

The management practices to be examined include: (1) intensive rotational grazing and continuous grazing 
during the growing season, (2) pasture "stockpiling" during late summer and continued grazing throughout the summer, and (3) two outwintering practices and no outwintering. An artificial hydraulic control was installed at each pasture outlet. The control is a threeinch Parshall flume. Each site will use a pressure transducer to measure stage and a CR-10 data recorder. Daily, monthly, and annual surface-water runoff will be calculated at each pasture. A tipping-bucket rain gage was installed at each site. Evapotranspiration will be estimated using empirical equations. Air temperature and solar radiation will be collected at one of the pastures for use in the evapotranspiration calculation. Meteorological data collected at the USDA Research Station will supplement data collected at this pasture. Ground-water flow will be calculated as a residual. An ISCO automatic water-quality sampler was installed at each site. The sampler will collect discrete samples. These samples will be composited on a flow-weighted basis. One composite sample per rainfall or snowmelt event will be sent to the Wisconsin State Laboratory of Hygiene for analysis. All events will be monitored. Approximately 5-10 samples per pasture will be collected. All samples will be analyzed for soluble reactive phosphorus, total phosphorus, ammonia nitrogen, nitrate and nitrite nitrogen, total Kjeldahl nitrogen, total suspended solids, and volatile suspended solids.

\section{PROGRESS (July 2001 to June 2002)}

Three small basins were monitored for continuous streamflow and rainfall. Four runoff samples collected at site 1 , six runoff samples at site 2 , and one runoff sample at site 3. Water-quality-constituent loads and subsequent yields were calculated at all three sites. Runoff events include summer thunderstorms and early winter rainfall and snowmelt events. Suspended solids yields were compared at the three sites. The median yields for suspended solids were the greatest at site 1
( $5.77 \mathrm{lb} / \mathrm{acre})$, at site 2 the median suspended solids yield was $1.53 \mathrm{lb} /$ acre, and at site 3 the suspended solids yield was $0.24 \mathrm{lb} / \mathrm{acre}$. A nonparametric Wilcoxon test was done to determine if the median yields were statistically the same or the alternative hypothesis that the medians were less than or greater than each other. The median suspended solids yields were statistically significantly different than each other when comparing site 1 with site 2 and site 3 . The median yields were not statistically different from each other when comparing site 2 and site 3 . The ammonia nitrogen yields ranged from $0.004 \mathrm{lbs} /$ acre (site 3 ) to $0.008 \mathrm{lb} /$ acre (site 1 ). None of the median ammonia nitrogen yields were statistically significantly different from each other at the 5-percent probability level. The total phosphorus median yield was $0.016 \mathrm{lb} /$ acre at site $1,0.005 \mathrm{lb} /$ acre at site 2 , and $0.007 \mathrm{lb} /$ acre at site 3 . The total phosphorus yield at site 1 was statistically significantly different from the median total phosphorus yields at site 2 but not at site 3 at the 5-percent probability level. All data was summarized and published in the report "Water Resources Data-Wisconsin, Water Year 2001."

\section{PLANS (July 2002 to June 2003)}

Monitoring at all three sites will be continued. Water-quality samples will be collected at the three sites for all storms that produce runoff and water-quality loads and yields will be calculated for each storm. Animal grazing will be allowed according to the Managed Intensive Rotational Grazing for each site. Yields will be compared at each site before grazing was started at each basin and after grazing was started. In addition site 1 (no out-wintering of animals) and site 2 and 3 (where out-wintering is part of the grazing plan) will be compared with each other to determine if differences can be found. All streamflow and water- quality data will be published in the annual report "Water Resources Data-Wisconsin, Water Year 2002."

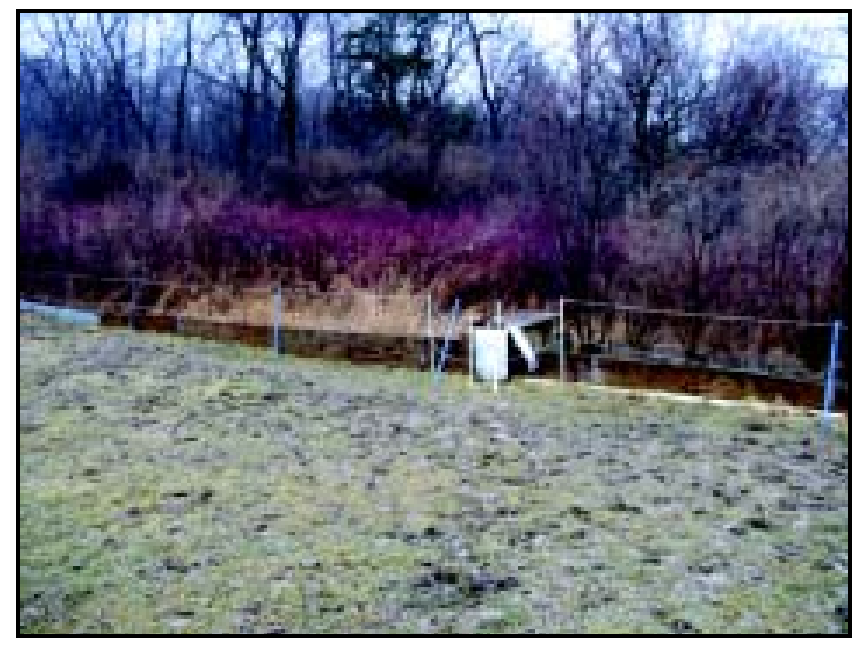




\section{DISCOVERY FARMS}

\section{COOPERATOR:}

Wisconsin Department of Natural Resources

PROJECT CHIEF:

Todd D. Stuntebeck

\section{LOCATION:}

Buffalo County

PROJECT NUMBER:

WI 17239

PERIOD OF PROJECT:

July 2001 to June 2003

\section{PROBLEM}

Agricultural nonpoint pollution in the form of nutrients, sediment, and pesticides threatens many of Wisconsin streams and lakes. Understanding how to help reduce these pollutants while allowing farmers to remain economically viable provides a great challenge.

\section{OBJECTIVE}

Under the new Wisconsin Agriculture Stewardship Initiative, groups will work together to develop sciencebased, productive, and profitable approaches to farming. Projects will be conducted on numerous "Discovery Farms" which will represent diverse land characteristics and management styles. Information learned from these projects will then be shared with the agricultural community to allow them the tools to remain competitive in today's market while taking environmentally sound approaches to farming.

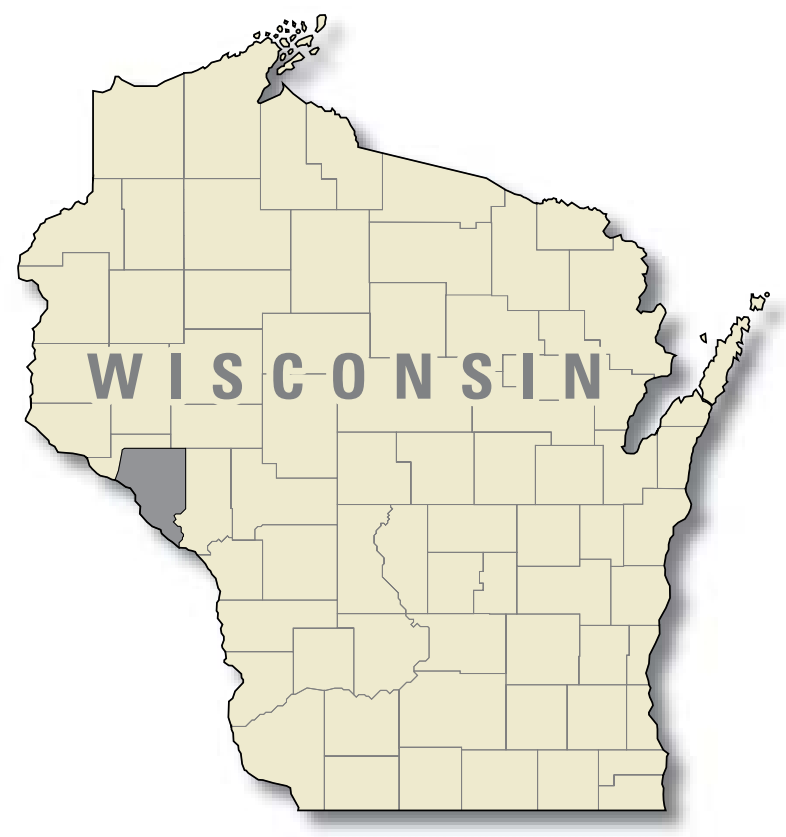

\section{APPROACH}

Stream Buffer Investigation-Traverse Valley Creek on the Joe Bragger Farm, Buffalo County-A "paired-watershed" study design will be applied in which a control site will be compared to a treatment site. The basis of this approach is that water-quality relation can be established between the treatment and the control site before BMPs (Best Management Practices) are implemented. When BMPs are implemented at the treatment site, the established relation will change if the BMPs have had a significant impact on water quality. The monitoring period will last approximately five years, with two years of pre-BMP data collection, a oneyear implementation/transition period with no sampling, and a two-year post-BMP sampling phase. At this time, a specific BMP has not been decided; however, it will likely focus on buffer strips. 
Four gaging stations will be installed on or near the Bragger Discovery Farm: one each on two tributaries to Traverse Valley Creek and two on nearby hillslopes. The two stream gages will be equipped to monitor water levels, water temperature, and precipitation; and to collect automated, refrigerated water samples, while the hillslope gages will be equipped to measure flow and samples. Surface-water samples will be collected from the stream sites during baseflow periods and storms. Baseflow samples will be collected at each monitoring station on a bi-weekly basis starting after the gages are installed. Samples will be analyzed at the Wisconsin State Laboratory of Hygiene for total phosphorus, total dissolved phosphorus, suspended solids, volatile suspended solids, total suspended sediment, nitrate plus nitrite, total Kjeldahl nitrogen, ammonia, chloride, fecal coliform bacteria, alkalinity, conductivity, and $\mathrm{pH}$. Flow-composite, automated, water samples will be collected for all storms with a significant overland-runoff component. Samples will be triggered by a combination of precipitation and water-level increases, and will be analyzed for the same constituents as baseflow samples.

In addition to the paired-watershed design, several other investigations will be conducted on various aspects on the farm. These studies may include, but not be limited to: a whole-farm mass balance of nitrogen and phosphorus, comparisons of stream gage-measured sediment loads versus RUSTLE II predicted values, development, calibration, and verification of a phosphorus-loss risk index, development, calibration and, verification of a hydrologic and chemical model (surface and ground water), and cow diet/manure implications.

\section{PROGRESS (July 2001 to June 2002)}

Both of the stream gages at the Bragger Discovery Farm became fully operational in September 2001. Since then, 9 baseflow and 13 storm samples have been collected at each site. A cursory review of the collected data shows that nitrate concentrations in the north basin are significantly higher than those in the south basin. The north basin has much more cropped agriculture than the south basin. It has also become apparent that aspect to the sun is very important for winter/spring snowmelt: north-facing slopes melt much more slowly than do south-facing slopes. This phenomenon has important implications for the hydrologic models that will be created. For this reason, each of the hillslope gages will be placed on slopes of different aspect.

\section{PLANS (July 2002 to June 2003)}

Two flumes will be installed on two forested hillslope drainages at the Bragger Discovery Farm-each on slopes of different aspect. The purpose of these gages will be to determine how much stormwater, and associated chemicals, comes from these steep, unfarmed areas. Based on a nearby study, it is suspected that these areas act as significant recharge zones for ground water.

An additional monitoring site will be included in this project sometime after July 2002. Specific sites to be monitored and the research to be conducted on each site has not yet been determined.

Baseflow and storm sampling will continue on the Bragger Discovery Farm.

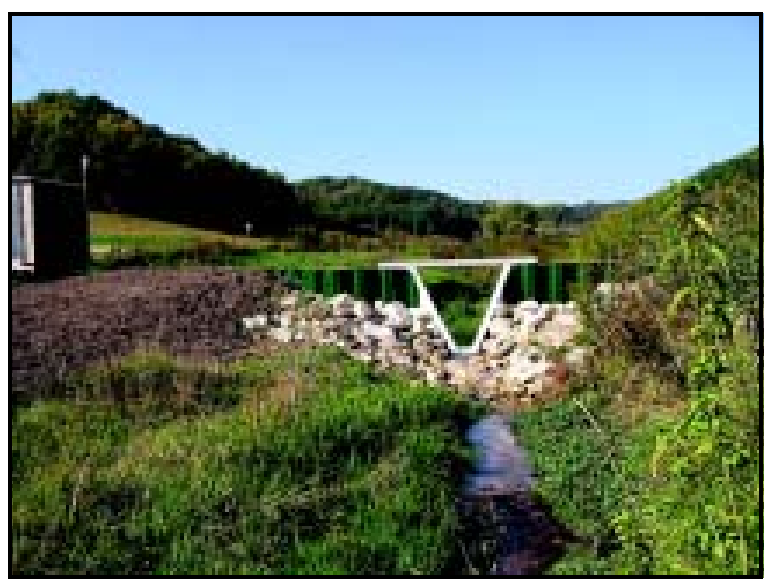

Streamgage at North Tributary to Traverse Valley Creek, showing flume with wing walls and instrumentation shelter. 


\section{QUANTIFICATION OF CONSTITUENT LOADS FROM FARM FIELDS AT THE PIONEER FARMS IN WISCONSIN}

\section{COOPERATOR:}

State of Wisconsin Pioneer Farm

PROJECT CHIEF:

David W. Owens

\section{LOCATION:}

University of Wisconsin, Platteville Experimental Farms

PROJECT NUMBER:

WI 17240

\section{PERIOD OF PROJECT:}

October 2001 to October 2003

\section{PROBLEM}

Wisconsin has many operating farms throughout the state where Best Management Practices (BMPs) could be implemented. These BMPs are designed to protect the environment and enhance the farm operations. Many farmers, however, do not want to implement BMPs without knowing the cost and benefits of each BMP. The Pioneer Agricultural Stewardship Farm located at the University of Wisconsin, Platteville Farm has been established to evaluate and promote management practices within the context of the farming systems in order to develop compatible methods and technologies that will help farmers achieve their economic goals while protecting and enhancing natural resource.

\section{OBJECTIVE}

The main objective of this project is to provide field level water quality and quantity data from rainfall and snowmelt runoff events. This data will be used to (1) verify the Wisconsin Phosphorus Index, (2) verify the Revised Universal Soil Loss Equation (RUSLE) and Revised Universal Soil Loss Equation II (RUSLE II) (3) establish "base-line" in stream conditions and (4) evaluate individual BMPs such as infiltration trenches and/or rotational grazing practices.

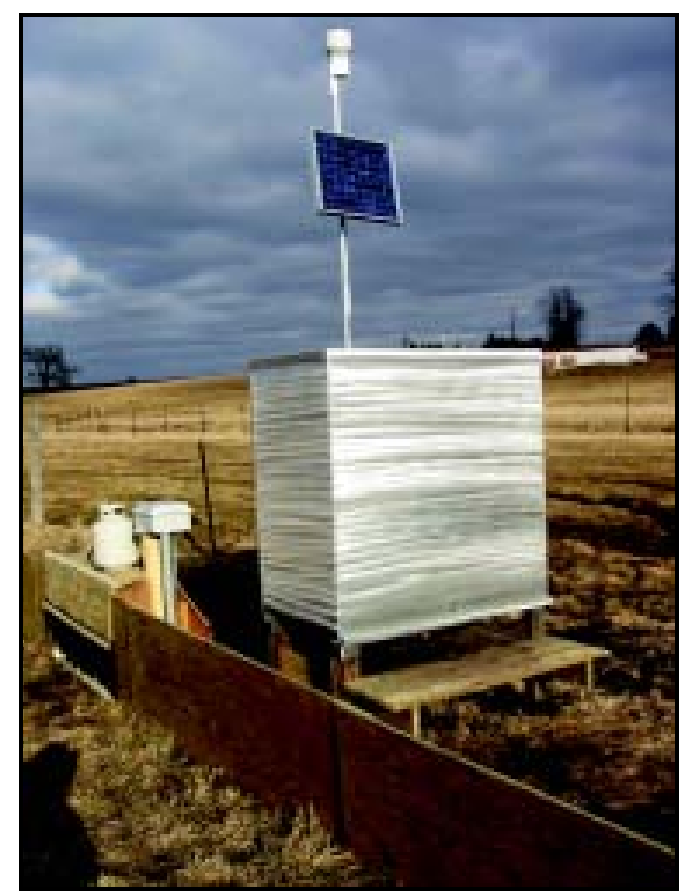

Gaging station at the University of Wisconsin-Platteville experimental farms.

\section{APPROACH}

Water quality monitoring stations will be installed at several sites throughout the experimental farm. These sites include five field level stations and one in-stream station located downstream of the experimental farm. The stations will monitor runoff volume and will collect water quality samples throughout the runoff event. These samples will be analyzed for solids, nutrients, bacteria and selected pesticide concentrations. Stations need to be designed to collect data during snow-melt runoff events.

\section{PROGRESS (October 2001 to June 2002)}

Four field level water-quality sampling stations were installed during the winter. Event monitoring started in mid-March 2002.

\section{PLANS (July 2002 to June 2003)}

Install in-stream and field level control sampling stations. Maintain and operate monitoring stations. 


\section{GROUND-WATER SYSTEMS TEAM}

\section{Mission}

The mission of the Ground-Water Systems Team is to provide a pool of expertise in a variety of disciplines from which flexible and dynamic sub-teams are formed to conduct District projects. The team serves as a forum in which participating members are kept abreast of new techniques and approaches in ground-water research and investigations. The team provides technical review for existing ground-water projects and designs and presents proposals to cooperators. Team membership fosters a close working relationship with cooperators and the University community. The team provides cooperators with state-of-the-art techniques and expertise to provide an understanding of ground-water systems and its relationship to natural resources and man.

\section{Team Members}

James T. Krohelski, Hydrologist

Randy J. Hunt, Research Hydrologist/Geology

Charles P. Dunning, Physical Scientist

David A. Saad, Hydrologist/Geology

Daniel T. Feinstein, Hydrologist

James M. Rauman, Hydrologic Technician Cheryl A. Buchwald, Hydrologic Technician Paul F. Juckem, Student Trainee (Hydrology) Gregory D. Mueller, Hydrologic Technician
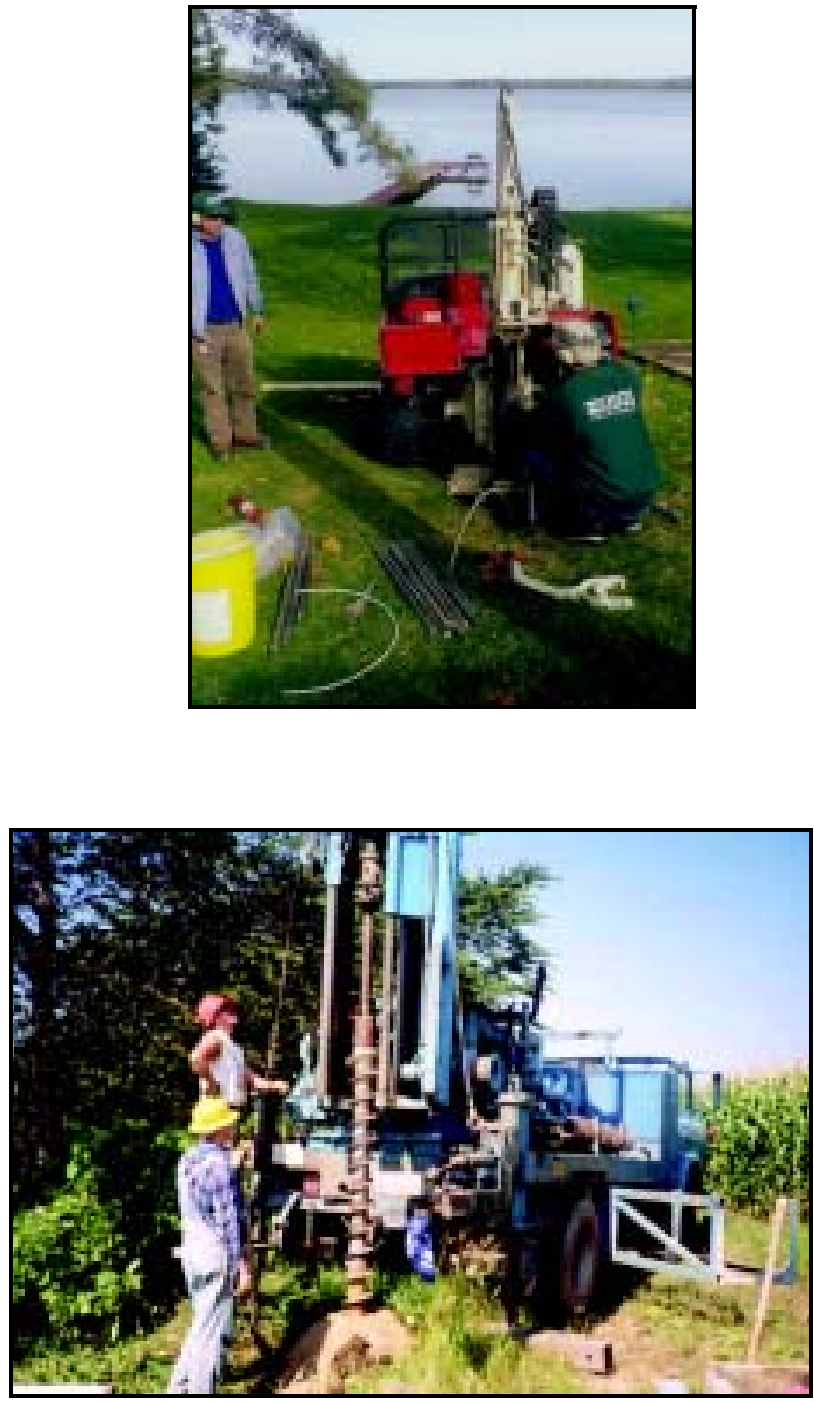

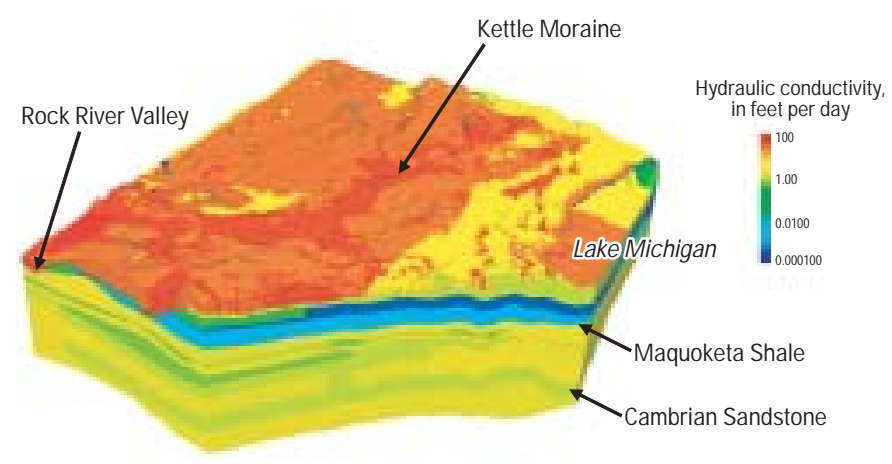

Southeast Wisconsin Ground-Water Flow Model 


\section{PROJECTS}

Crandon ground water, WI 00201

Simulation of shallow-ground-water flow on the Stockbridge Munsee Indian Reservation with the use of an analytic element model, WI 12307

Characterization of the regional aquifer flow-system on the Menominee Indian Reservation, WI 12312 ....................... 42

Monitoring contaminant flux from a stormwater infiltration facility to ground water, WI 12738 ................................. 44

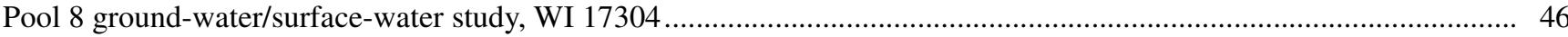

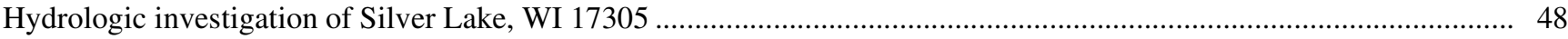

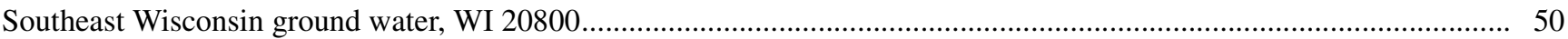

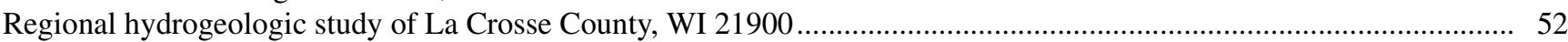

Susceptibility of La Crosse Municipal Wells to enteric virus contamination from surface water contribution, WI 21901 54

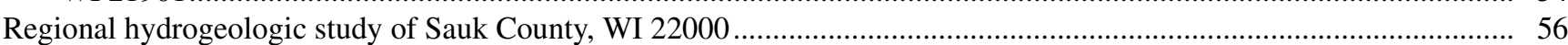

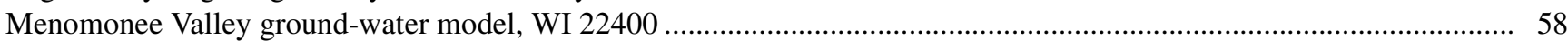




\section{CRANDON GROUND WATER}

\begin{tabular}{l} 
COOPERATOR: \\
Wisconsin Department of Natural \\
Resources \\
PROJECT CHIEF: \\
James T. Krohelski \\
LOCATION: \\
Forest County \\
PROJECT NUMBER: \\
WI 00201 \\
PERIOD OF PROJECT: \\
October 1994-Continuing \\
\hline
\end{tabular}

\section{PROBLEM}

A large underground zinc-copper mine is being proposed at a site about five miles south of Crandon, Wisconsin, in Forest County. The Wisconsin Department of Natural Resources (WDNR) requested that District staff review the development of a ground-water-flow model and associated hydrologic documents as part of a permitting process for the proposed mine.

\section{OBJECTIVE}

The objective is to review documents related to water resources submitted to WDNR from the Nicolet Minerals Company and their consultants; and to make suggestions to WDNR on studies and approaches that will improve the understanding of the hydrology and effects of mining on the water resources in the vicinity of the proposed mine.

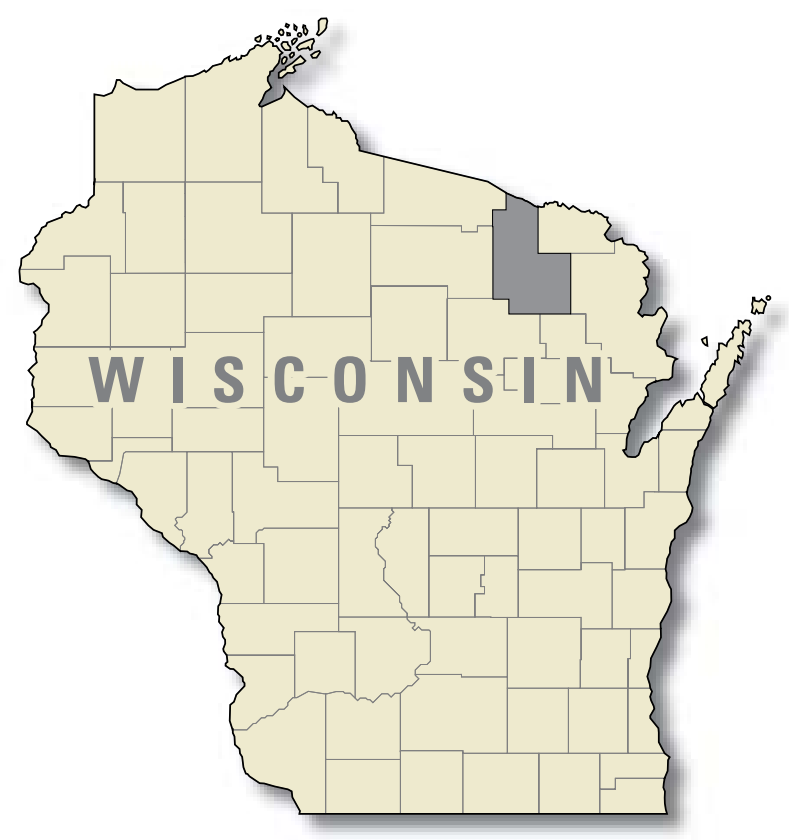

\section{APPROACH}

The schedule for review of documents will be mutually agreed upon between WDNR and USGS.

\section{PROGRESS (July 2001 to June 2002)}

The Technical Working Group's draft report for the ground-water- flow model was completed. A review of the TMA and Reflooded mine contaminant transport models was continued. Monitoring of lake stage and shallow ground-water levels adjacent to Little Sand Lake and Skunk Lake were continued.

\section{PLANS (July 2002 to June 2003)}

Documents will be reviewed and meetings attended at the request of the WDNR. Complete the Technical Working Group's report for the groundwater-flow model. A review of the TMA and Reflooded mine contaminant transport models will be continued. Monitoring of lake stage and shallow ground-water levels adjacent to Little Sand Lake will be continued. 


\section{SIMULATION OF SHALLOW GROUND-WATER FLOW ON THE STOCKBRIDGE MUNSEE INDIAN RESERVATION WITH THE USE OF AN ANALYTIC ELEMENT MODEL}

\author{
COOPERATOR: \\ Stockbridge-Munsee Band of \\ Mohican Indians \\ PROJECT CHIEF: \\ Charles P. Dunning

\section{LOCATION:} \\ Stockbridge-Munsee Reservation \\ PROJECT NUMBER: \\ WI 12307

\section{PERIOD OF PROJECT:} \\ January 2002 to September 2003
}

\section{PROBLEM}

The Stockbridge-Munsee Indian Tribe of northeastern Wisconsin is interested in increasing their understanding of regional ground-water flow across the reservation. This understanding can be applied to a variety of water management needs, and will enable the Tribe to make informed decisions about water quantity and quality issues.

\section{OBJECTIVE}

The objective of this study is to develop an understanding of the regional ground-water flow system across the Stockbridge-Munsee Indian Reservation, and to provide the Tribe a tool to investigate a wide range of water resource problems.

\section{APPROACH}

Water supply for the Stockbridge-Munsee Indian Reservation is provided primarily by wells completed in unconsolidated glacial sediments. Numerous methods and approaches are available for investigating ground-

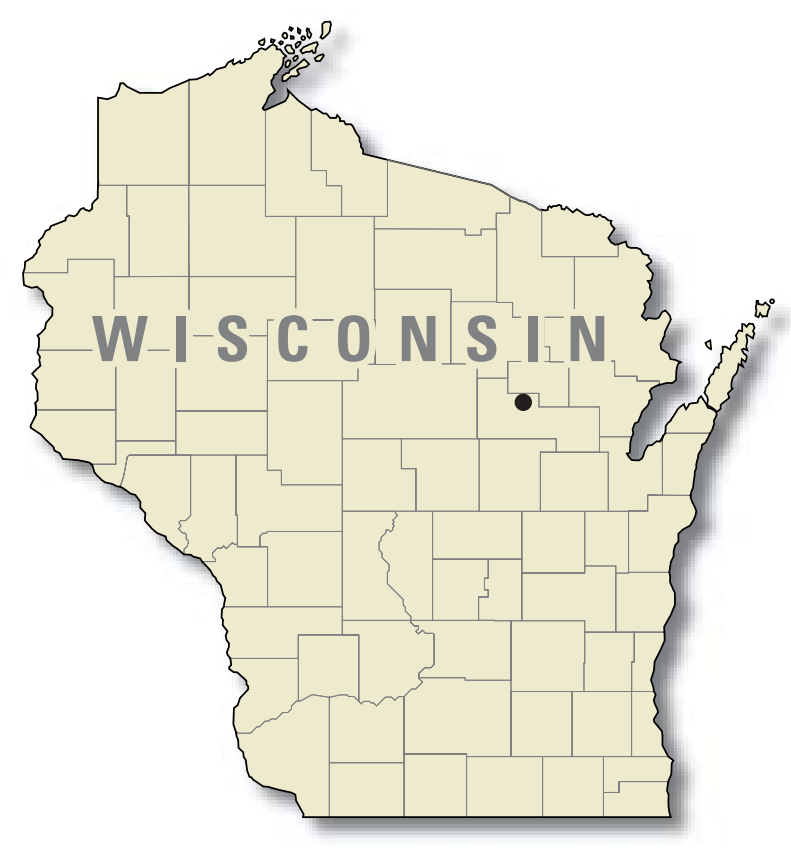

water flow, ranging from simple analytical techniques to sophisticated computer modeling (U.S. Environmental Protection Agency, 1994; Blandford and others, 1994; Haitjema and others, 1994). The relatively uncomplicated nature of the glacial sediment aquifer on the reservation suggests that a single-layer, steady state Analytic Element (AE) ground-water-flow model will be appropriate to simulate the ground-water flow system.

The AE model code GFLOW (Mitchell-Bruker and Haitjema, 1996) will be used to simulate the groundwater/surface-water system across the StockbridgeMunsee Reservation. Once the model is calibrated to measured ground-water levels and stream flows it can be used to simulate and plot the direction of groundwater flow and ground-water travel time. The results of this study will provide the Tribe with a water resources management tool that will help assess the fate and transport of contaminants and provide the necessary information to plan well-head protection strategies for the community well systems. The Tribal staff will benefit from this study by learning appropriate techniques to determine contributing areas and time of travel. The 
study will help determine areas where future data collection may be needed to understand the complexities of the ground-water-flow system.

\section{PROGRESS (July 2001 to June 2002)}

Hydraulic detail has been added to the regional GFLOW model around the Stockbridge-Munsee reservation area. Hydraulic head and stream flow targets have been compiled and added to the model. Additional stream flow measurements were taken at several locations across the reservation. Model calibration is ongoing, and the model is being used to address a number of water management issues.

\section{PLANS (July 2002 to June 2003)}

The GFLOW model will be used to evaluate current water management issues of the Stockbridge-Munsee tribe. A report will present results of the study and an interpretation of the shallow ground-water-flow system across the reservation. The report will also document model construction and calibration. 


\section{CHARACTERIZATION OF THE REGIONAL AQUIFER FLOW-SYSTEM ON THE MENOMINEE INDIAN RESERVATION}

\begin{tabular}{|l|}
\hline COOPERATOR: \\
Menominee Indian Tribe of \\
Wisconsin \\
PROJECT CHIEF: \\
Charles P. Dunning \\
LOCATION: \\
Menominee County \\
PROJECT NUMBER: \\
WI 12312 \\
PERIOD OF PROJECT: \\
October 1998-Continuing \\
\hline
\end{tabular}

\section{PROBLEM}

The Menominee Indian Tribe is interested in determining the contributing areas and time of travel for water captured by wells for a number of community water systems in Menominee County, Wisconsin. The Tribe's interest in well-head protection is heightened over concern about the presence of elevated nitrate levels in several wells.

\section{OBJECTIVE}

The objective of the study is to determine the contributing areas and time of travel for water captured by community wells. This information will be used by the Menominee Indian Tribe for water resource and wellhead protection planning in community areas.

\section{APPROACH}

The USGS will construct a simple one-layer ground-water model to simulate the hydrologic conditions in an appropriate area around community wells. The ground-water model will be used to delineate the

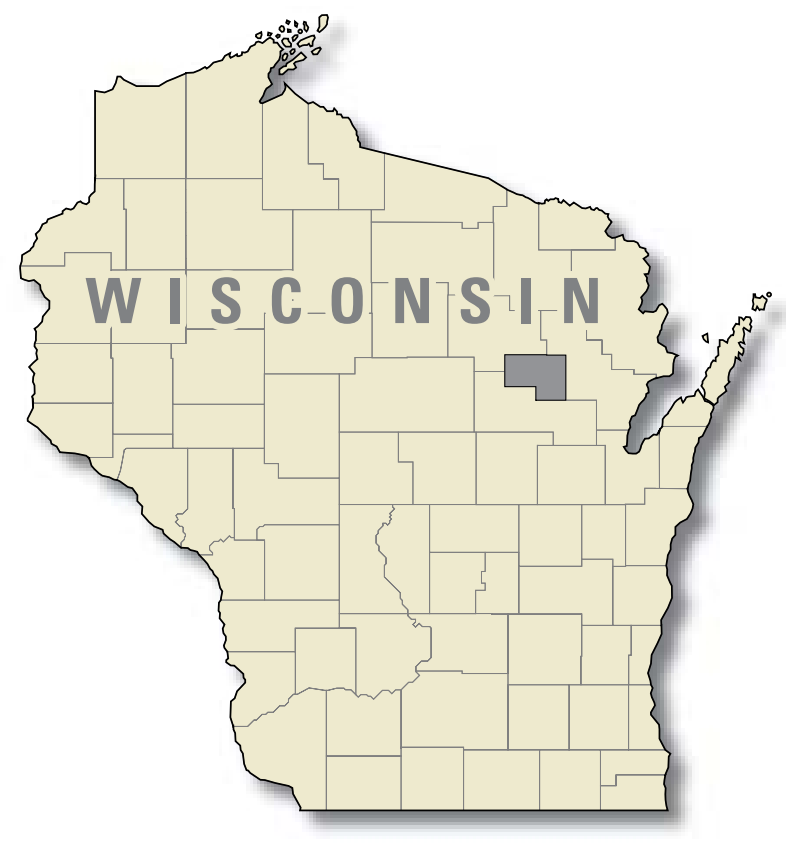

zone of ground-water contribution to the wells for 5-, 10 - and 100-year times of travel, and define the associated area of contribution. The results of these investigations will provide the Tribe with the necessary information to plan a well-head protection strategy for each community system.

\section{PROGRESS (July 2001 to June 2002)}

The reservation-wide analytic element model has been in the process of calibration. Assistance was provided to the Menominee Indian Tribe in identifying locations around Zoar that will avoid the elevated nitrate found in the current wells. As a result, a location meeting all the requirements has been identified. Field activities for the hydrogeologic study around the town of Neopit were completed, though some stream gaging continues periodically. The results and interpretation of the Neopit study focusing on the community wells and the sewage treatment lagoons is being finalized. A new investigation has been undertaken to locate favorable locations for new municipal wells in the town of Keshena. The regional ground-water-flow model was used in 
this investigation to identify locations around Keshena that would likely be free of septic or contamination sources.

\section{PLANS (July 2002 to June 2003)}

The USGS drill rig will be used to investigate the depth to bedrock and saturated thickness of potential sites around Keshena. Specific ground-water-flow modeling is underway at three other communities on the Reservation-Middle Village, Onekewat, and Redwing. Results of these investigations will be presented as Water-Resources Investigation Reports. 


\section{MONITORING CONTAMINANT FLUX FROM A STORMWATER INFILTRATION FACILITY TO GROUND WATER}

\section{COOPERATOR:}

Wisconsin Department of Natural Resources

\section{PROJECT CHIEF:}

Charles P. Dunning

\section{LOCATION:}

Dane County

PROJECT NUMBER:

WI 17238

\section{PERIOD OF PROJECT:}

July 2001 to July 2003

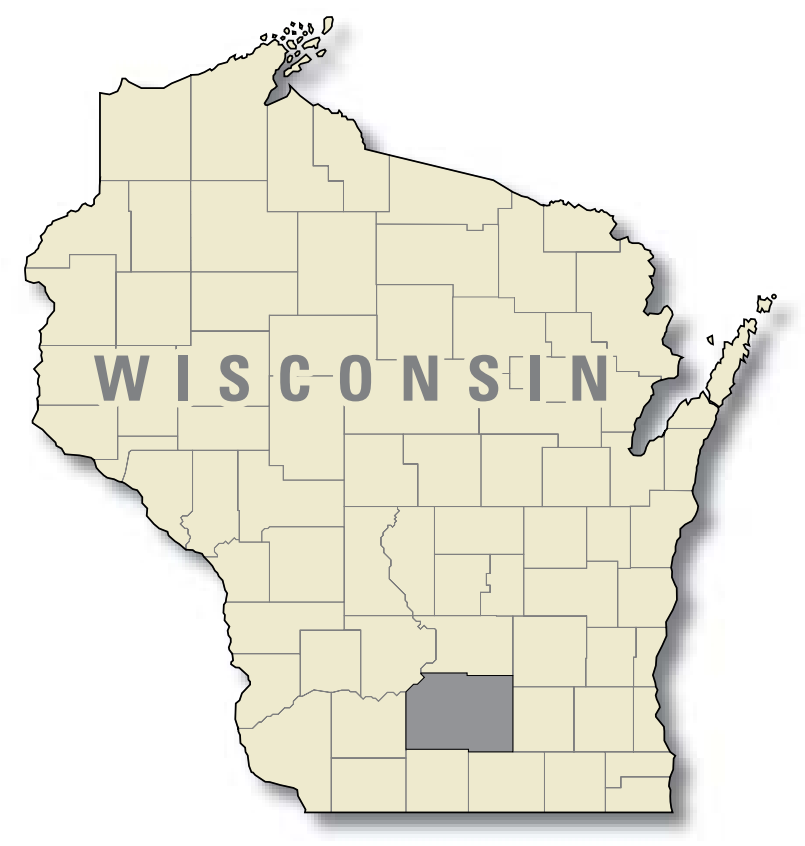

\section{APPROACH}

Following preliminary investigation at sites in central Dane County, it has been decided to focus on two sites in the city of Middleton. One site is an infiltration basin that serves Stonefield, a residential neighborhood, and has been in place for about 10 years. The other is an infiltration trench installed next to a new parking lot that is a part of the expansion of the Middleton High School. At these two sites, a small diameter water-table monitoring well will be installed to observe the specific relation between stormflow events and the elevation of the water table. The use of an equilibrium-tension lysimeter at these sites has been abandoned in favor of porous cup suction lysimeters, because of the need to be able to change the vertical location of sampling points in response to insight gained as the project progresses. During installation of monitoring wells we expect to characterize the soil and moisture profiles of each site. This information will be used in choosing initial installation points for lysimeters in the vadose zone. The disadvantage of the new approach is that it will be more difficult to infer with precision the hydrologic balance 
of stormflow infiltration and/or mass-balance of contaminants than would have been possible with the equilibrium-tension lysimeter. Monitoring and sampling of lysimeter leachate, stormwater and ground water will be carried out using a combination of automated and manual means. Data gathered over the course of this study will be compiled and interpreted to characterize the flux of infiltrated contaminants to ground water. The relation between stormwater quality and contaminant flux will be evaluated.

\section{PROGRESS (July 2001 to June 2002)}

At the Stonefield Neighborhood site a soil boring has been completed to a depth of 30 feet, and reveals a change from soil and clay at the top of the section to dry, clean, fine sand at the bottom. The dry sand prevented deeper penetration with the Geoprobe. This boring will be extended to the water table with rotary augers and a pressure transducer will be installed to monitor ground water levels. A slotted standpipe was installed at the control structure that provides outflow from the infiltration basin to the stormwater sewer system. This standpipe allows the measurement of pond stage during stormwater events. Data have been compiled for the period from the April installation of the standpipe to present (data continue to be collected).

Preliminary interpretation of data suggests that changes in barometric pressure are observed in both the transducer monitoring barometric pressure and the transducer monitoring water level in the standpipe. The difference between values measured by these two transducers represents the pressure due to standing water over the transducer in the standpipe (pond stage). Tem- perature data suggest that a measurable rise in water temperature in the standpipe occurs with each stormwater event. Preliminary data also suggest that even a moderate rainfall ( 0.5 inches or less) will result in significant ponding within the infiltration basin, generally from about 1 to 2 feet deep though as deep as about 4.5 feet. It must be kept in mind however, the reported depth of rainfall is for Madison in general and the actual depth of precipitation over the contributing area to the Stonefield infiltration basin will likely be somewhat different. Following ponding in the basin a combination of leakage between stop planks at the control structure to the stormflow system and the infiltration well will cause the stage to drop rapidly. Once the level drops to about the basin bottom the rate at which the water level drops much more slowly.

At the Middleton High School site a pressure transducer has been installed in a standpipe in the infiltration trench. Monitoring of water level in the trench resulting from stormflow events began March 28, 2002.

\section{PLANS (July 2002 to June 2003)}

During selected stormwater events water-quality samples will be taken of the stormwater, leachate from the unsaturated zone, and water table. Initial water-quality samples will serve to check the integrity of the lysimeters and well points, and provide a measure of initial contaminant concentrations. Water-quality sampling may be conducted at regular time intervals, in response to an infiltration event, or in both instances. Data will be compiled, interpreted, and summarized in a report to the Wisconsin Department of Natural Resources. 


\section{POOL 8 GROUND-WATER/SURFACE-WATER STUDY}

\section{COOPERATORS: \\ U.S. Geological Survey, \\ Water Resources Discipline \\ National Stream Quality Accounting \\ Network Program \\ U.S. Geological Survey, \\ Biological Resources Discipline}

\section{PROJECT CHIEF:}

Randy J. Hunt

\section{LOCATION:}

Southwestern Wisconsin

PROJECT NUMBER:

WI 17304

\section{PERIOD OF PROJECT:}

May 1999 to October 2002

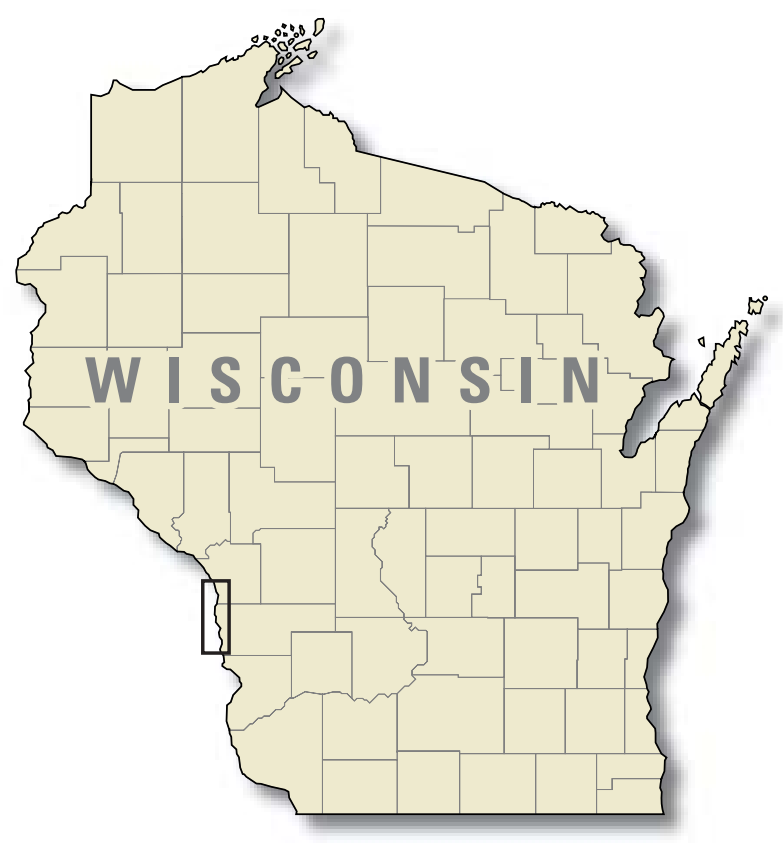

data. Results of the initial model were then used to guide future data collection, which was used to update the model. The initial ground-water-flow model was constructed using analytic element methods. Different system conceptualizations were tested by coupling the analytic element model to a parameter estimation code. The field work included on-shore installation of permanent well nests to characterize the local and regional ground-water systems and collection of ground-water samples for nutrient analyses. The analytic element model was translated to a three-dimensional model using the finite-difference code MODFLOW. The resulting three-dimensional model and geochemical sampling will be used to construct maps of groundwater discharge, flowpaths, and travel times.

\section{PROGRESS (July 2001 to June 2002)}

Groundwater level data collection has continued. A three-dimensional MODFLOW model has been extracted from the analytic element model and calibrated to the ground-water-level data and streamflow data. Ground-water discharge zones and magnitude of 
ground-water flux and associated nitrate loading were determined using the calibrated model.

\section{PLANS (July 2002 to June 2003)}

A Water-Resources Investigations Report will be published describing the model construction and results.

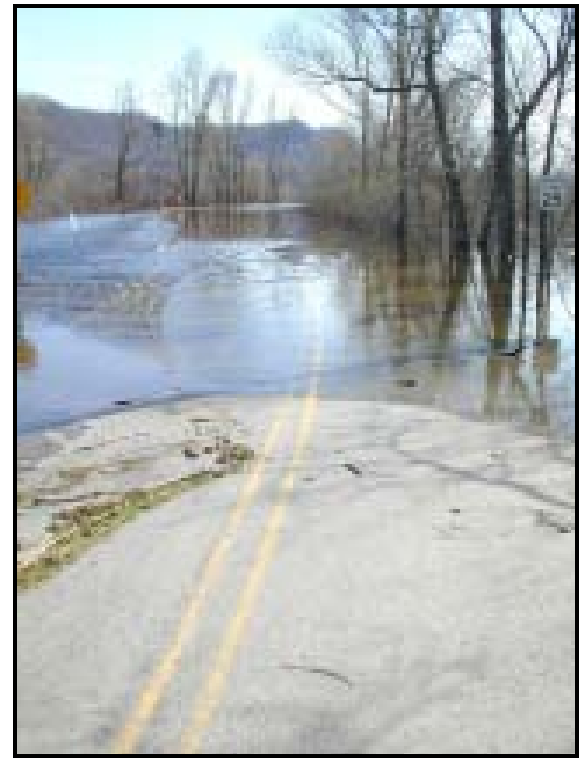

Flooding on Goose Island.

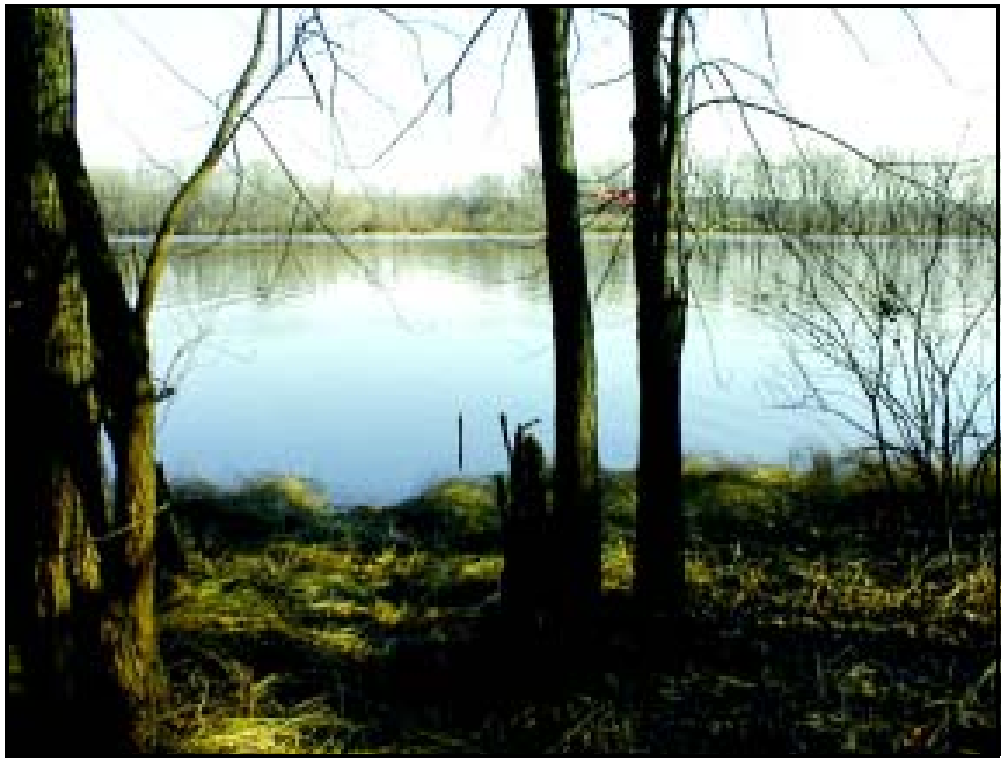

Pool 8 shoreline. 


\section{HYDROLOGIC INVESTIGATION OF SILVER LAKE}

\section{COOPERATOR: \\ Silver Lake Protection and Rehabilitation District \\ PROJECT CHIEF: \\ Charles P. Dunning \\ LOCATION: \\ Washington County \\ PROJECT NUMBER: \\ WI 17305 \\ PERIOD OF PROJECT: \\ October 1999 to September 2001}

\section{PROBLEM}

Silver Lake is a ground-water seepage lake located in central Washington County, southeastern Wisconsin. Because of its strong hydraulic connection to the shallow ground-water-flow system, Silver Lake could be affected adversely by land-use changes in its watershed. The Silver Lake Protection and Rehabilitation District seeks a better understanding of the ground-water flow system around Silver Lake and means to evaluate the effect of land-use changes.

\section{OBJECTIVES}

Specific objectives are to: (1) determine the hydraulic parameters and budget components of Silver Lake, (2) identify key ground-water recharge areas for Silver Lake, and (3) quantify the loading to the lake due to ground-water inflow.

\section{APPROACH}

Historical hydrologic data will be used to develop a numerical ground-water-flow model of Silver Lake and

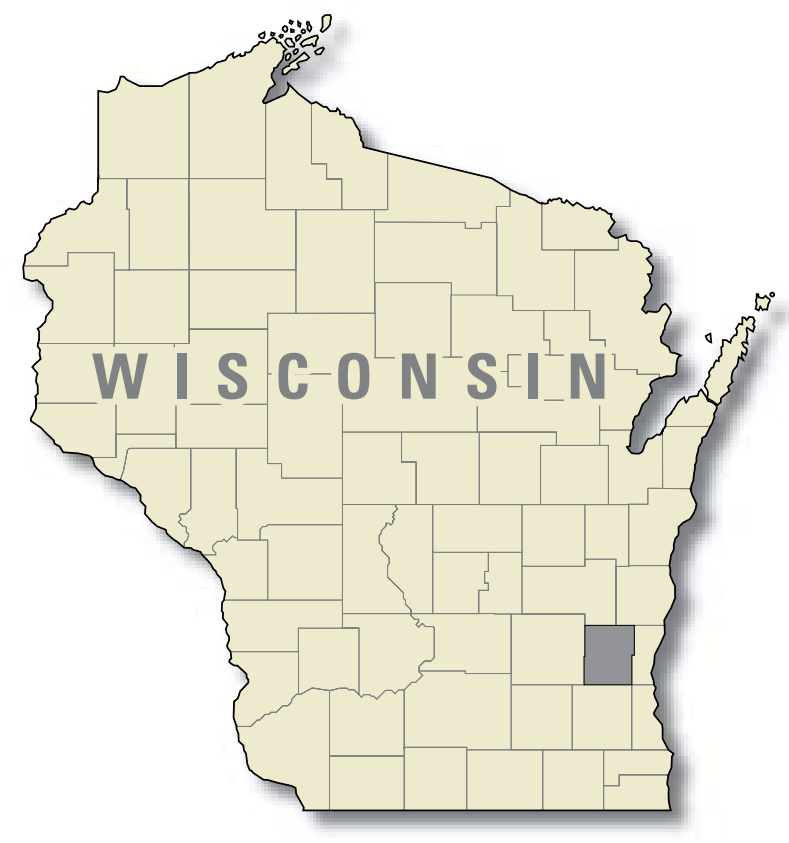

its watershed. Water budget parameters to be included in the model are precipitation, evaporation, and measured water levels and flows. This model will be calibrated to lake stage and discharge as well as hydraulic heads and stream flows.

\section{PROGRESS (July 2001 to June 2002)}

Study is complete. Report is in review. Hydraulic parameter values for the shallow aquifer have been estimated through characterization of the study area and calibration of the AE model. Based on results of the calibrated model, hydraulic conductivity of the shallow aquifer ranges from 20 to $50 \mathrm{ft} / \mathrm{d}$, lower in the Kettle Moraine Area and greater in the surrounding areas. The rate of recharge varies from 4 to $12 \mathrm{in} / \mathrm{yr}$, higher in the Kettle Moraine Area and lower in surrounding areas. The hydrologic budget components for Silver Lake have been determined and their values estimated. Stream flow from Silver Lake was computed as a residual in the hydrologic budget and compared to measured flows. Precipitation on the lake minus evaporation from the lake is reported in the literature to be about $0.04 \mathrm{ft}^{3} / \mathrm{s}$ 
( $3 \mathrm{in} / \mathrm{yr}$ ). Model results show ground-water flow into Silver Lake is $1.08 \mathrm{ft}^{3} / \mathrm{s}$, and flow from Silver Lake to the shallow aquifer is $0.08 \mathrm{ft}^{3} / \mathrm{s}$. The residual of $1.04 \mathrm{ft}^{3} / \mathrm{s}$ is the stream flow from Silver Lake to Silver Creek and matches observed flows very well. Groundwater-recharge areas for Silver Lake have been simulated using backward tracking of particles in the $\mathrm{AE}$ model. Using a porosity of 20 percent, areas for times of travel of 10, 20, and 50 years were defined. Nearly all the ground water flowing to Silver Lake comes from recharge areas to the west The recharge area for the northern two thirds of Silver Lake lies west toward Big Cedar Lake, though the 50-year time of travel does not extend all the way to Big Cedar Lake. The recharge area for the southern one third of Silver Lake lies west toward Little Cedar Lake. The time of travel from Little Cedar Lake to Silver Lake is between 15 and 20 years.
The solute flux toward Silver Lake was estimated using average concentrations measured in observation wells and the simulated ground-water flux. However, in order to estimate solute mass loading to Silver Lake from ground-water discharge, it would be necessary to characterize the nature of the sediment-water interface, as well as the chemistry of the pore water in the lake littoral region (within about 1 meter of the interface). Solutes like nitrogen and phosphorous would likely be very affected by biotic and abiotic processes near the sediment-water interface.

\section{PLANS (July 2002 to June 2003)}

A Water-Resources Investigation Report will be published.

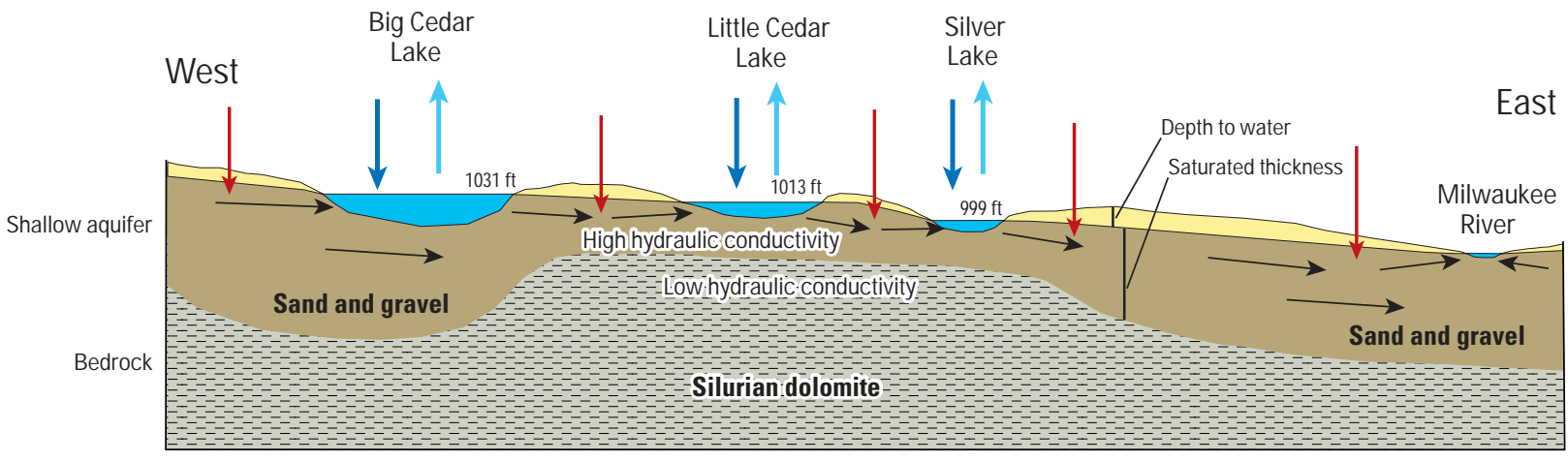

Explanation

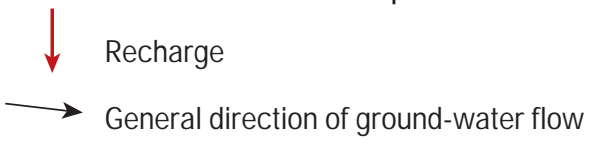

$\downarrow$ Precipitation
$\uparrow$ Evaporation 


\section{SOUTHEAST WISCONSIN GROUND WATER}

\section{COOPERATOR:}

Wisconsin Geological and Natural History Survey

\section{PROJECT CHIEF:}

Daniel T. Feinstein

\section{LOCATION:}

Southeastern Wisconsin

PROJECT NUMBER:

WI 20800

PERIOD OF PROJECT:

February 1998 to September 2003

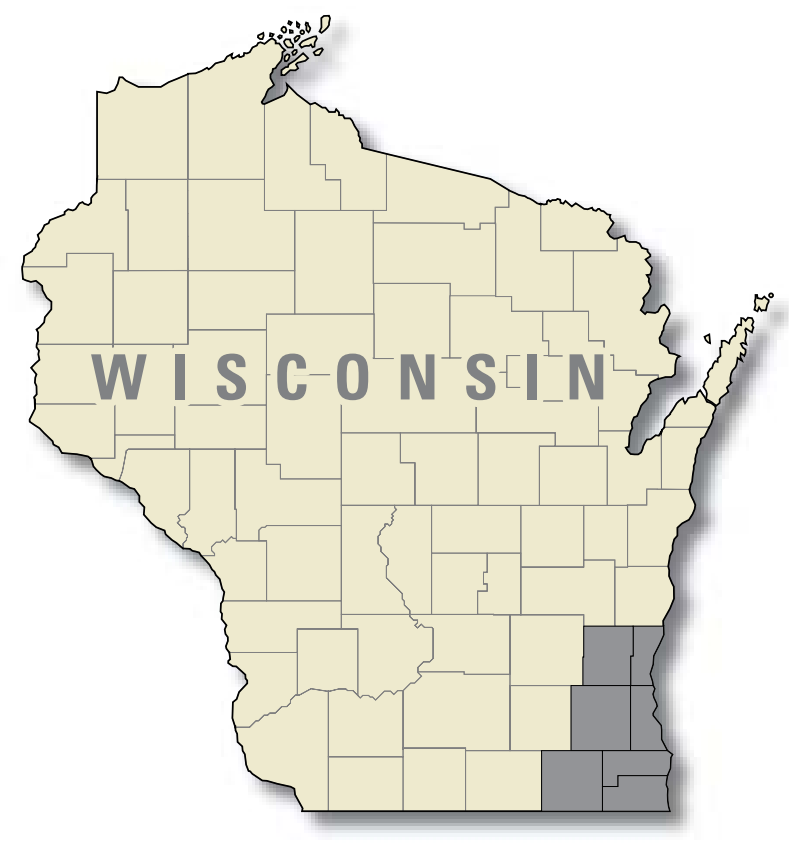

under different use scenarios for purposes of delineating capture zones and wellhead protection areas, evaluating well interference, and examining ground-water/surfacewater connections; and (3) permit optimization of future well placement and pumping schedules by use of submodels.

\section{APPROACH}

The water utilities need information from the USGS to decide on a regional strategy for optimizing water supply. Specifically they need a framework to decide on the spacing, number, and, perhaps most critically, the open interval. A balance is needed between relatively thin shallow aquifers that are potentially subject to surface contamination and the underlying thick sandstone aquifer that suffers from excessive drawdown, increasing salinity, and potential radium influx. Optimization depends on many factors: for example, mapping of recharge areas to the shallow system and the sandstone aquifer, evaluation of the exchange between the two systems across units such as the Maquoketa Shale, and a better understanding of the stratigraphy in the deep sandstone aquifer. A regional three-dimensional model will serve as the platform for integrating 
these factors. It will also serve as the tool for simulating optimization scenarios.

\section{PROGRESS (July 2001 to June 2002)}

This year we constructed and calibrated the steadystate model representing pre-development conditions, then constructed and calibrated the transient model representing the response of the shallow and deep systems to over 100 years of pumping. Tasks included: (1) insertion of water bodies, recharge zones and bedrock valleys at the top of the model, (2) zonation of horizontal and vertical hydraulic conductivity in both shallow and deep model layers, (3) preparation of calibration targets for the pre-development model including 19th century water levels in the sandstone aquifer and estimated fluxes to streams, (4) preparation of shallow and deep calibration targets for the transient model including well hydrographs, packer-test data, and location of water divides through time, (5) calibration of the predevelopment model using parameter estimation methods, (6) tabulation of water use from the late 19th cen- tury to the present in both the shallow and deep systems, (7) calibration of the transient model to match long-term trends in observed drawdown throughout the study area, (8) analysis of model results with emphasis on the spatial distribution of sources of water to wells, (9) preparation of a report (published by the Wisconsin Geological and Natural History Survey) summarizing model construction, calibration and results, and (10) cooperation with groups interested in constructing local inset models extracted from the regional model.

\section{PLANS (July 2002 to June 2003)}

The remaining work on the project involves delineation of capture zones to define well-head protection and development of optimization scenarios to guide management of the ground-water resource. These products will be issued in a report. Efforts to refine and improve the model will continue in order to account for features such as abandoned wells and the Milwaukee Deep Tunnel. Public outreach including possible webbased projects will be undertaken.

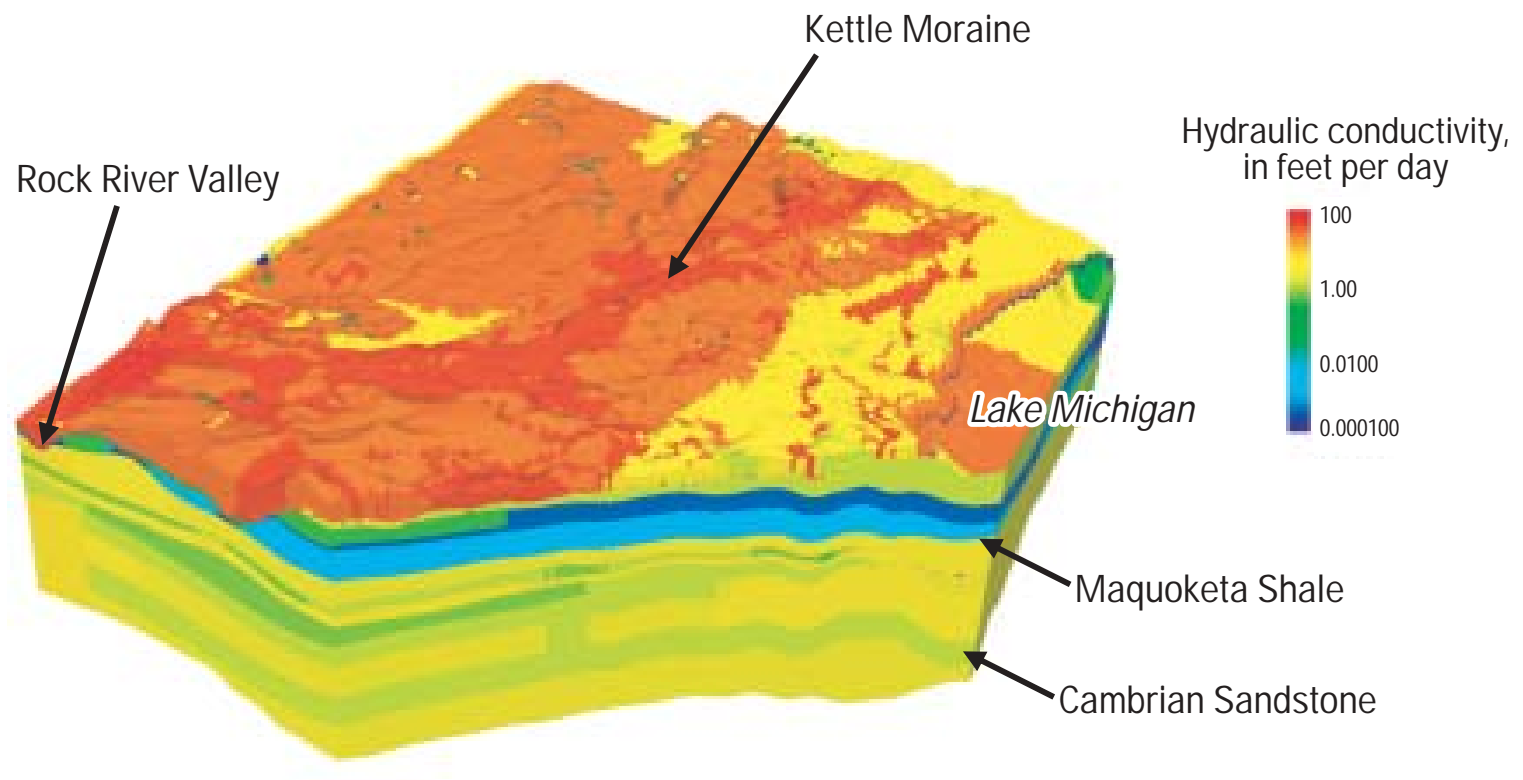

Southeast Wisconsin Ground-Water Flow Model 


\section{REGIONAL HYDROGEOLOGIC STUDY OF \\ LA CROSSE COUNTY}

\author{
COOPERATORS: \\ Wisconsin Department of Natural \\ Resources, and \\ Wisconsin Geological and Natural \\ History Survey

\section{PROJECT CHIEF:} \\ Randy J. Hunt

\section{LOCATION:} \\ La Crosse County \\ PROJECT NUMBER: \\ WI 21900 \\ PERIOD OF PROJECT: \\ July 2000 to October 2002
}

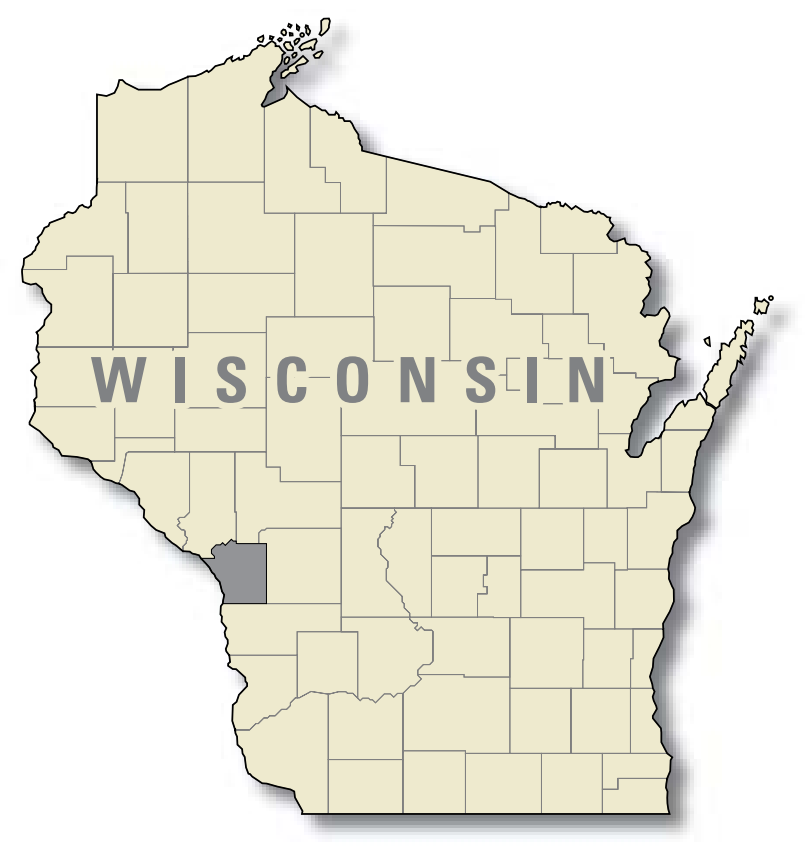

model; quantitatively identify the zone of contribution for each municipal ground-water supply system in the county using numerical modeling techniques; and encourage water-resource management and protection by introducing and promoting the use of study products through educational and outreach efforts in La Crosse County.

\section{APPROACH}

Existing information regarding the spatial distribution and hydraulic properties of hydrogeologic units and water-use data will be compiled. A three-dimensional model will be developed based on conceptual and initial analytic element screening models. Additional field data will be collected in areas requiring better definition or resolution of hydraulic parameters or to provide more complete coverage of water levels or streamflows. The model will be calibrated by comparing simulated ground-water levels and streamflows to measured values. Zone of contributions for the 68 municipal supply wells within the county will be delineated using particle tracking and selected management scenarios will be simulated. 


\section{PROGRESS (July 2001 to June 2002)}

Ground-water-level, streamflow, and precipitation data collection has continued. A deep observation well has been drilled and undergone geophysical and hydrologic testing in cooperation with the Wisconsin Geological and Natural History Survey. A three-dimensional MODFLOW model has been extracted from the ana- lytic element model and calibrated to the ground-waterlevel data and streamflow data.

\section{PLANS (July 2002 to June 2003)}

A Water-Resources Investigations Report will be published describing the model construction and results.

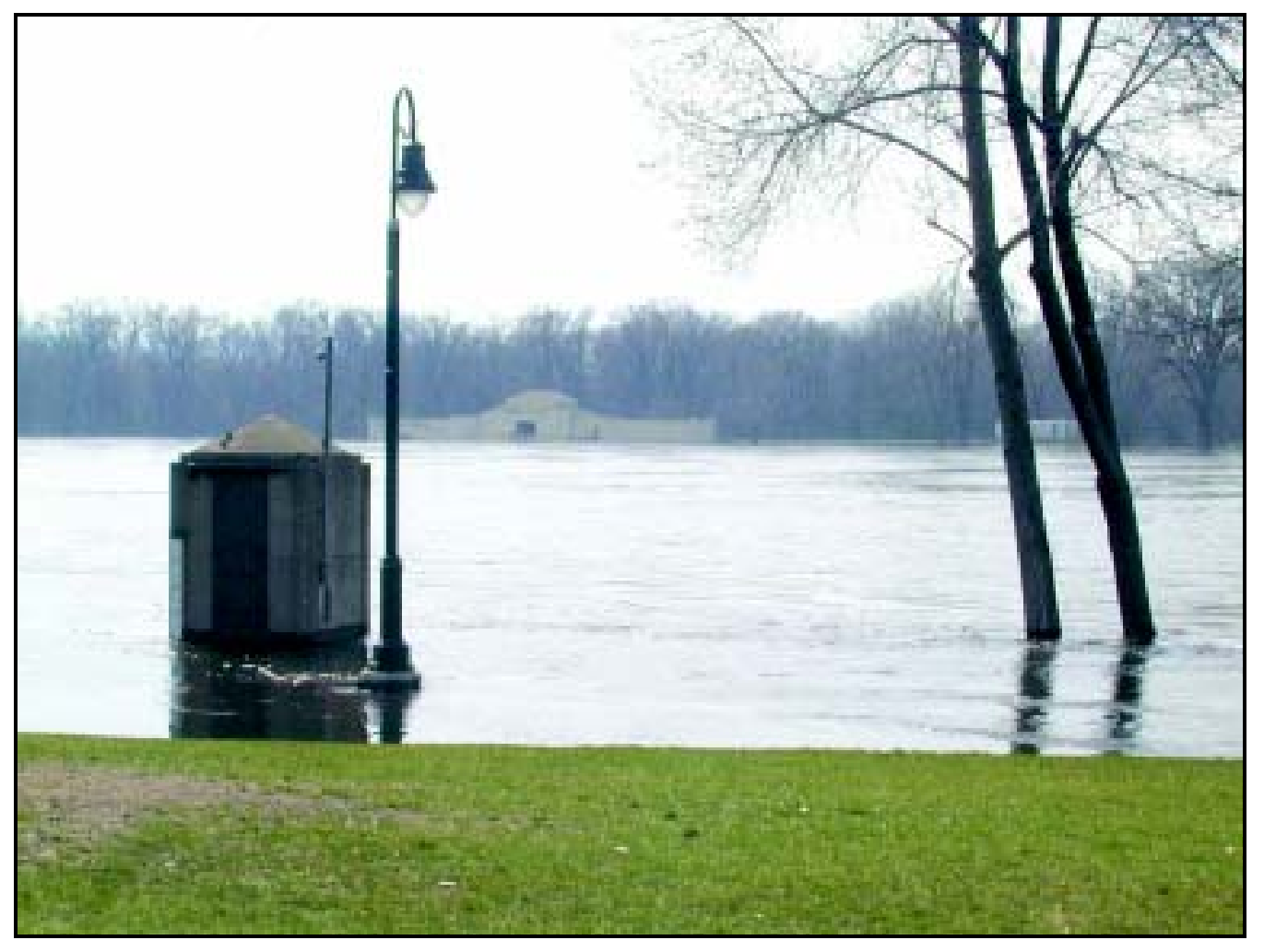

Flooding near Riverside Park, La Crosse, April 2001. 


\section{SUSCEPTIBILITY OF LA CROSSE MUNICIPAL WELLS TO ENTERIC VIRUS CONTAMINATION FROM SURFACE WATER CONTRIBUTIONS}

\section{COOPERATOR: \\ Marshfield Medical Research Foundation \\ FUNDING AGENCY: \\ Wisconsin Department of Natural Resources Groundwater Management Practice Monitoring Program \\ PROJECT CHIEF: \\ Randy J. Hunt \\ LOCATION: \\ City of La Crosse \\ PROJECT NUMBER: \\ WI 21901 \\ PERIOD OF PROJECT: \\ March 2001 to September 2002}

\section{PROBLEM}

Viruses derived from surface water are potential contaminants because they can move readily through the soil due to their extremely small size and negative charge at typical soil pH levels. Data on the extent and temporal nature of virus contamination of water-supply wells are limited because the techniques are expensive and specialized.

\section{OBJECTIVE}

Project objectives are: (A) document the presence of viruses in water-supply wells that have varying amounts of surface-water components, (B) assess the temporal nature of virus occurrence, $(\mathrm{C})$ quantify the amount of surface water present in the well discharge and determine the time of travel, and (D) relate $\mathrm{C}$ to $\mathrm{A}$ and $\mathrm{B}$.

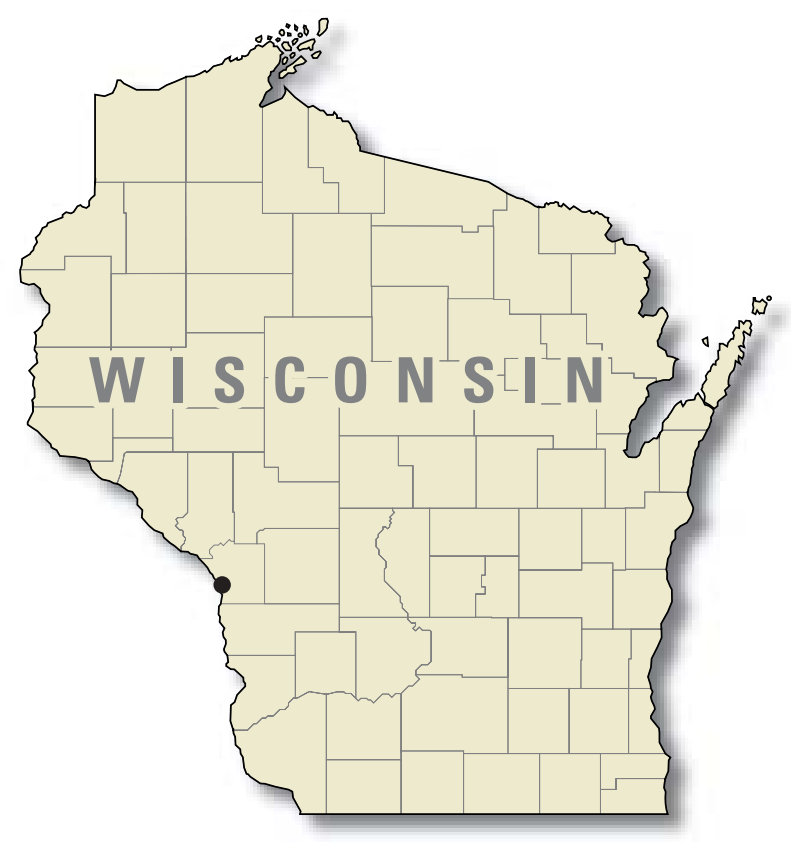

\section{APPROACH}

Particle-tracking identified three classes of watersupply wells: (1) those that are expected to have high surface water contributions, (2) those that have intermediate surface water contributions, and (3) those that are expected to have little or no surface water contributions. The sampling includes a surface water source, two wells of the first class of wells, and one well in each of the latter two classes, for a total of five samples per sampling period. Because of the transient nature of virus occurrence, the sites will be sampled frequently over time (12 times per year). Biological analyses will include reverse transcription-polymerase chain reaction (RT-PCR) for detecting human enteric viruses and analyses for microbiological indicators of water sanitary quality. In addition, water analyses will include water isotopes $\left({ }^{18} \mathrm{O} /{ }^{16} \mathrm{O},{ }^{2} \mathrm{H} /{ }^{1} \mathrm{H}\right)$ to identify amounts of 
surface water, and water tracers to date the age of the water.

\section{PROGRESS (March 2001 to June 2002)}

Samples have been collected monthly from March 2001 through February 2002. Virus and indicator analyses are ongoing. Water isotope sampling indicates detectable surface water contribution in two of the four wells. Two additional monitoring wells were installed between the surface water source and the adjacent municipal wells to collect water samples specific to the surface water source rather than a bulk average of all the flow that enter the well. The new wells were sampled for water isotopes, viruses, and age-dating using CFCs and ${ }^{3} \mathrm{H}-{ }^{3} \mathrm{He}$. In addition to continuing monthly virus, indicator, and water isotope sampling until February 2002, methodology for improving the virus test sensitivity is being evaluated.

\section{PLANS (March 2002 to September 2002)}

Analyses will be completed and a report written detailing the findings of the work.

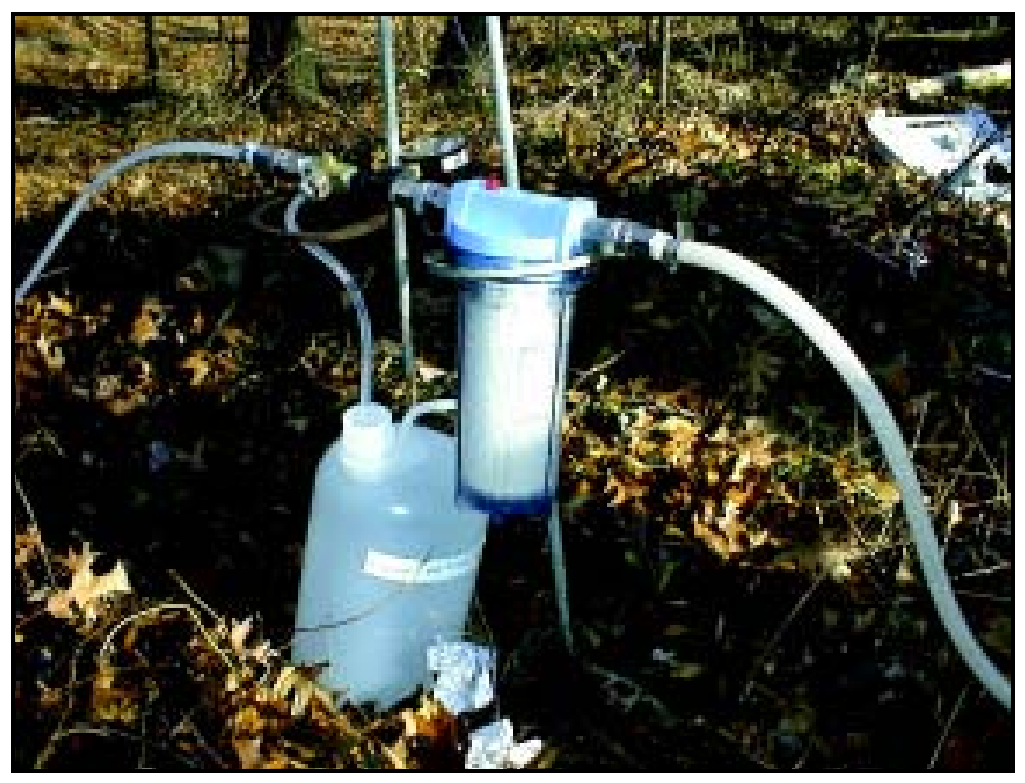

Virus filtering apparatus near La Crosse well 24. 


\section{REGIONAL HYDROGEOLOGIC STUDY OF SAUK COUNTY, WISCONSIN}

\begin{tabular}{|l|}
\hline COOPERATOR: \\
Wisconsin Geological and Natural \\
History Survey \\
PROJECT CHIEF: \\
Charles P. Dunning \\
LOCATION: \\
Sauk County \\
PROJECT NUMBER: \\
WI 22000 \\
PERIOD OF PROJECT: \\
July 2001-June 30, 2002 \\
\hline
\end{tabular}

\section{PROBLEM}

Sauk County is under increasing development pressure, particularly in the Lake Delton/Wisconsin Dells area. Local development patterns have given rise to concerns about ground-water quality and quantity. As a result, county planners and officials recognize the increased need for knowledge of regional hydrologic conditions in order to make informed water-resource and land-use planning decisions. The purpose of this project is to conduct a comprehensive study of Sauk County's hydrogeologic resources and to delineate the zones of contribution (ZOC) for municipal wells located in the county. This project has been designed to meet the data needs of source-water protection efforts in Sauk County, and to provide technical and educational resources to promote source-water protection initiatives.

\section{OBJECTIVE}

The purpose of the Sauk County ground-water study is to understand and document the regional ground-water-flow system, as well as the local hydrologic systems around population centers, so that water

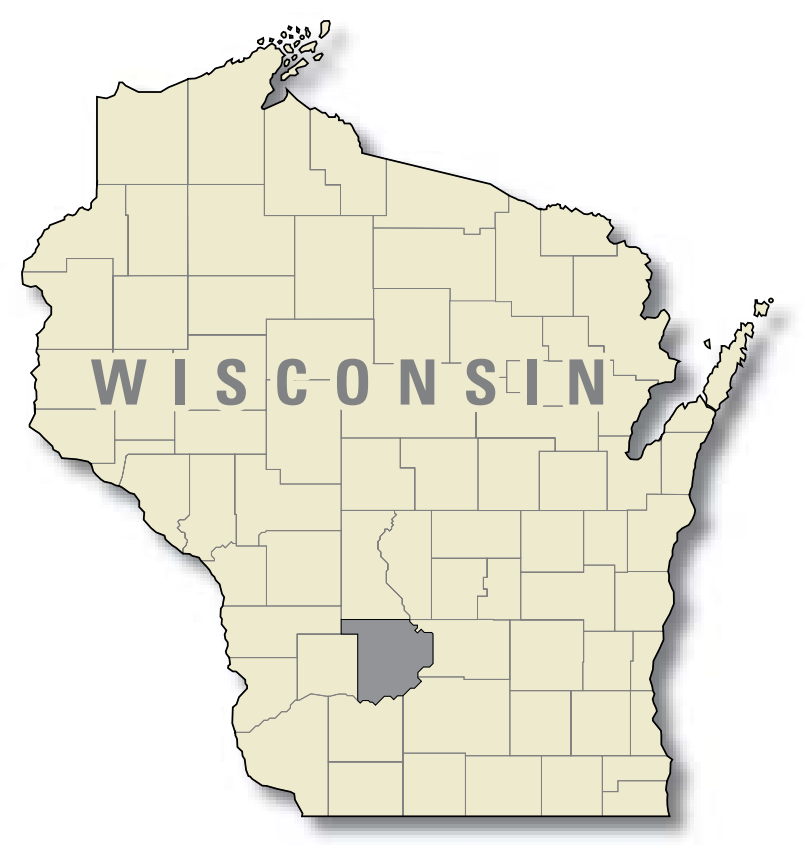

resources may be managed and preserved. The specific objectives are to: (1) collect, compile, and analyze data to characterize the regional ground-water-flow system and form a conceptual hydrogeologic model, (2) quantitatively identify the zone of contribution for each municipal ground-water supply system in the county using numerical modeling techniques, and (3) encourage water-resources management and protection by introducing and promoting the use of the study products through educational and outreach efforts in Sauk County.

\section{APPROACH}

The project plan involves three phases of work.

Phase 1—Characterization of Regional Hydrogeology

Existing information will be compiled regarding the spatial distribution and hydraulic properties of hydrogeologic units; water table and potentiometric surface maps of the significant aquifer units will be constructed; a model code for a regional screening level model will be selected and calibrated to the observed 
conditions; the data collection, mapping and modeling efforts will be synthesized to formulate a conceptual model of the regional hydrogeology; and a draft report prepared including the conceptual model, data, maps and study methods.

\section{Phase 2-Delineation of Zones of Contribution}

The regional screening model will be used to determine boundary conditions for "sub-models" that encompass the 13 municipal supply systems within the county; ZOC analyses will be performed for the municipal supply wells within the county; regional and submodel development will be documented; and ZOCs will be delineated.

\section{Phase 3-Education and Outreach}

Educational and outreach materials will be prepared by selecting pertinent information from the hydrogeologic and modeling reports and working with project partners in Sauk County to identify appropriate presentation opportunities. A summary of the project findings and modeling results will be presented to local boards and civic groups.

\section{PROGRESS (July 2001 to June 2002)}

Phase 2 has been completed. Hydrologists at the USGS Wisconsin District and the Wisconsin Geological and Natural History Survey (WGNHS) have determined ZOCs for the 13 municipalities. ZOCs were determined with the use of both analytic element (single layer) and finite difference (multi-layer) models. Some stream gaging was undertaken to help quantity flux targets for the regional model as well as for the Wisconsin Dells/Lake Delton sub-model. The WGNHS is taking the lead on Phase 3 activities which are underway.

\section{PLANS (July 2002 to June 2003)}

Support will be provided to the WGNHS in completing Phase 3 as necessary.

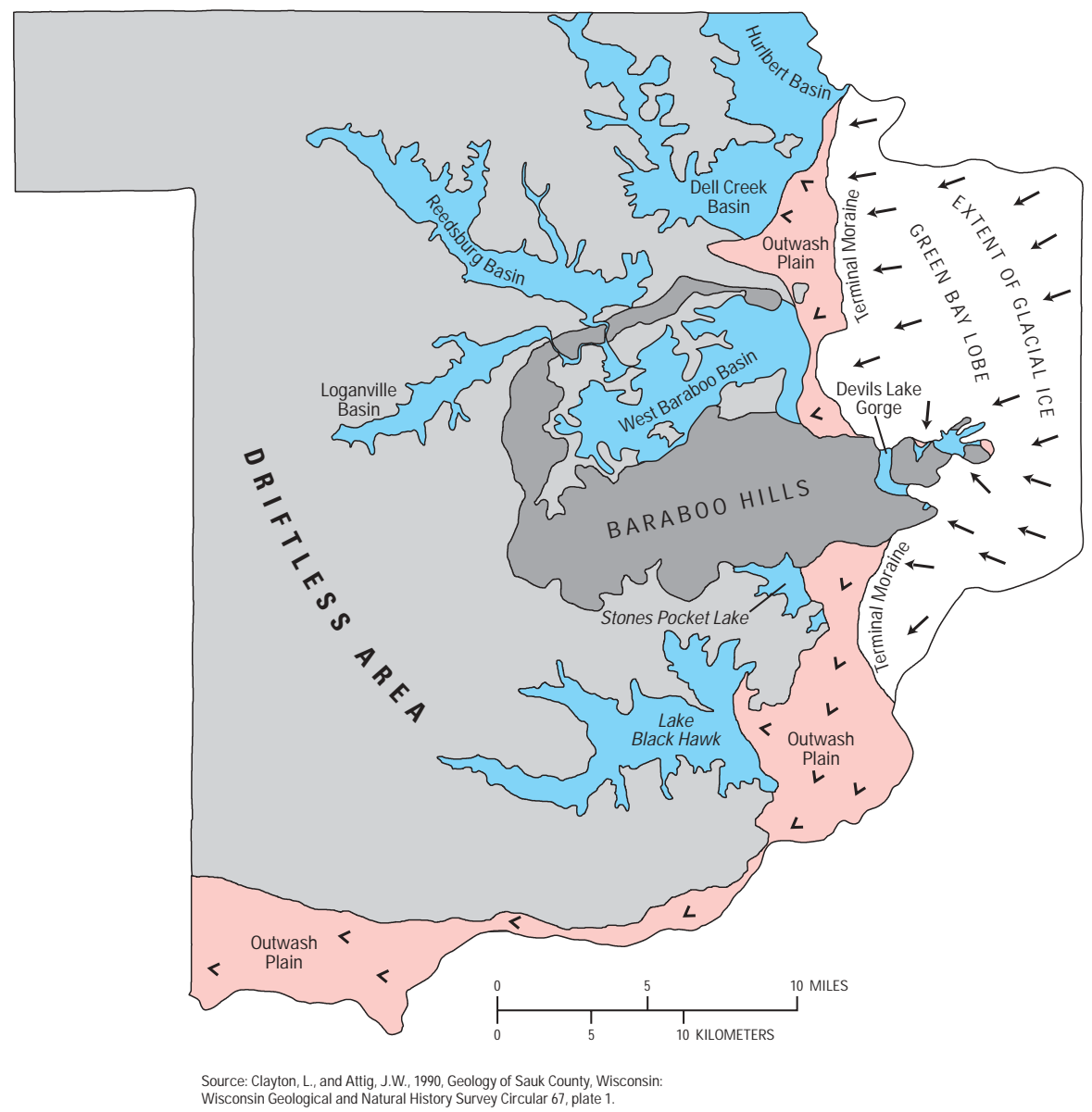

Major geologic features of Sauk County during the maximum late Wisconsin extent of the Green Bay Lobe. The map shows the location of the western edge of the Green Bay Lobe (arrows show direction of ice flow), outwash plains (red), and lakes (blue). The Baraboo Hills and the remainder of the Driftless Area in Sauk County are shown in shades of gray. 


\section{MENOMONEE VALLEY GROUND-WATER MODEL}

\section{COOPERATOR:}

City of Milwaukee

PROJECT CHIEF:

Daniel T. Feinstein

\section{LOCATION:}

Menomonee Valley, Milwaukee

PROJECT NUMBER:

WI 22400

PERIOD OF PROJECT:

February 2001 to June 2003

\section{PROBLEM}

The City of Milwaukee and the U.S. Environmental Protection Agency (USEPA), as part of an effort to promote "brownfield" development, have funded a series of data collection and modeling studies to determine the fate of recharge to valley lands adjacent to Lake Michigan. Two major receptors exist for recharge that flows through contaminated fill- the surface-water estuary and a Deep Tunnel system constructed about 200 feet below land surface to store runoff. The overall objective of these studies is to delineate the contributing areas for these receptors in order to determine how best to evaluate potential environmental concerns.

\section{OBJECTIVES}

The objectives are to: (1) build on an existing analytical element model of the Menomonee Valley by extracting a three-dimensional MODFLOW model from the one-layer GFLOW model, (2) compare the results produced by GFLOW and MODFLOW especially with respect to the fate of recharge to the Valley, and (3) cal-

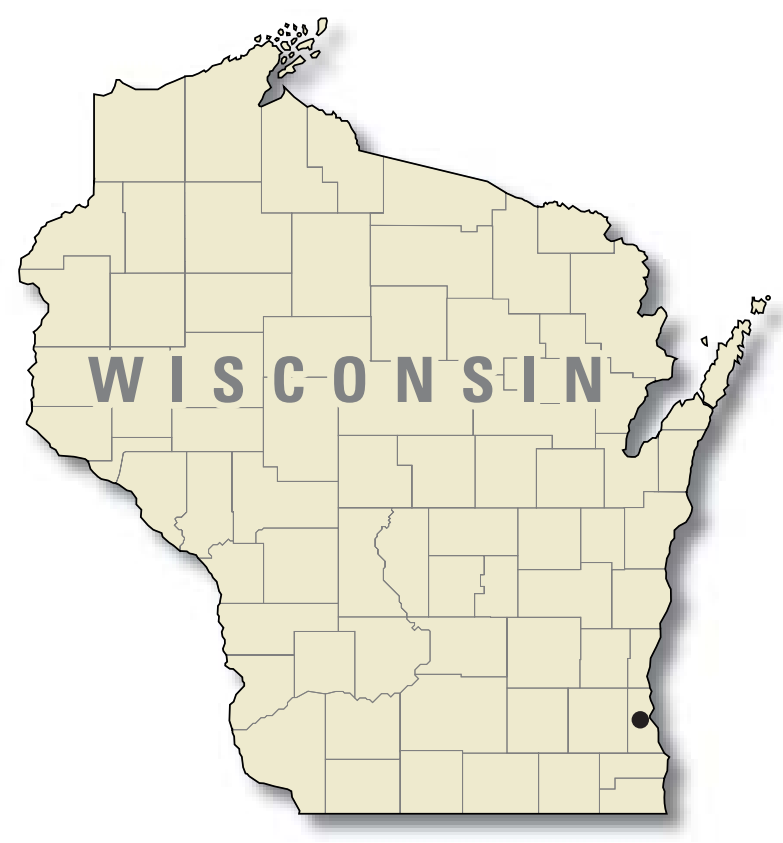

culate travel times to receptors such as the river estuary and the ISS based on the MODFLOW results.

\section{APPROACH}

A step-wise modeling approach was used in which a regional one-layer analytic element model simulates the flow system, but also furnishes boundary conditions for a local MODFLOW model. The MODFLOW model is capable of fully addressing three-dimensional flow from the water table to the Deep Tunnel.

\section{PROGRESS (June 2001 to June 2002)}

A new water-level calibration data set corresponding to August 2001 allowed much better definition of the vertical flow regime within the MODFLOW model. The output of the updated model served to demonstrate that while both shallow and deep receptors play a role in capturing local groundwater, the Deep Tunnel is the dominant sink for water recharging the Valley. Particle tracking in conjunction with model indicated that the average travel time for water discharging to the tunnel is on the order of 80 years. This length of time is impor- 
tant because it suggests that some contaminants carried by the groundwater will have sufficient time to attenuate before discharging to the Tunnel.

The ground-water model received a great deal of public attention. Several meetings were held with the Wisconsin Department of Natural Resources and the Milwaukee Journal-Sentinel to discuss the methodology and results. We were also requested by the journal Ground Water to submit an article on the modeling work (currently in review). Our results were widely distributed by the Menomonee Valley Partners, a community group interested in development of the area.

\section{PLANS (July 2001 to June 2003)}

The Milwaukee Metropolitan Sewer District has recently provided new data with respect to the amount of Tunnel infiltration that will require us to again recalibrate the model. The USEPA has agreed to provide an additional grant that will allow us to finish the modeling and produce a USGS publication, likely a WaterResources Investigation Report. We expect to complete the analysis and the report by the end of 2002.

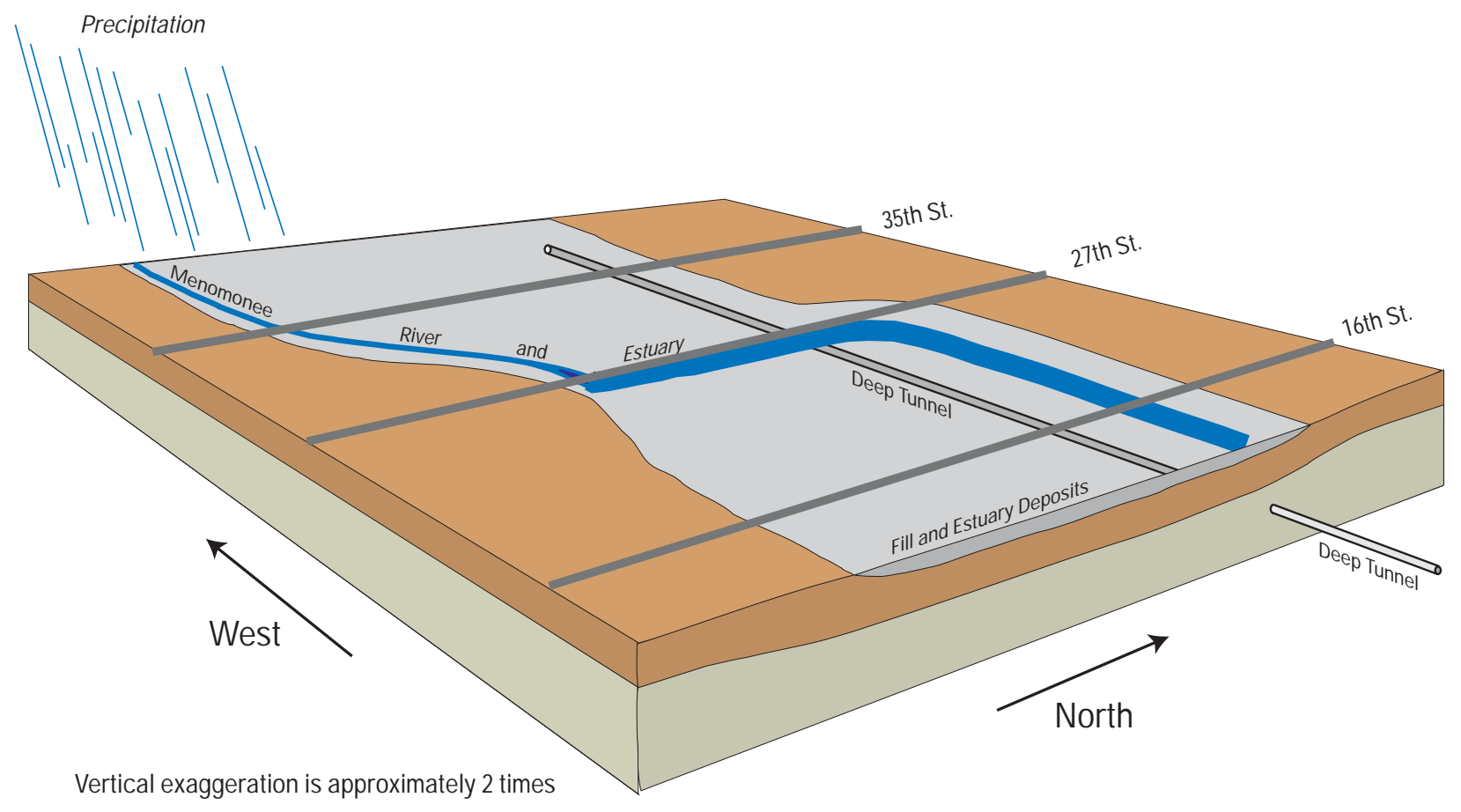





\section{LAKES STUDIES TEAM}

\section{Mission}

The purpose of the work team is to provide oversight and technical guidance on hydrology and water quality for District lake projects assigned to the team. Lakes are defined in the broadest sense to include both natural and artificial lakes. The team will provide a consistent policy for execution of lake projects, including planning and budgeting, data collection and management, and report preparation and review. For some projects, the team, or a subset of it, will be involved in all phases of the project—-from proposal development to final report preparation. For other projects, the team will serve as a resource and review board.

\section{Team Members}

William J. Rose, Hydrologist/Engineering John F. Elder, Research Hydrologist/Biology

Dale M. Robertson, Research Hydrologist/Chemistry Gerald L. Goddard, Hydrologic Technician Daniel L. Olson, Hydrologic Technician Brett M. Esser, Hydrologic Technician Elizabeth A. Mergener, Student Trainee (Hydrology) Elissa D. Roerish, Hydrologic Technician Rebecca L. Rewey, Hydrologic Technician Stephanie M. Berg, Hydrologic Technician
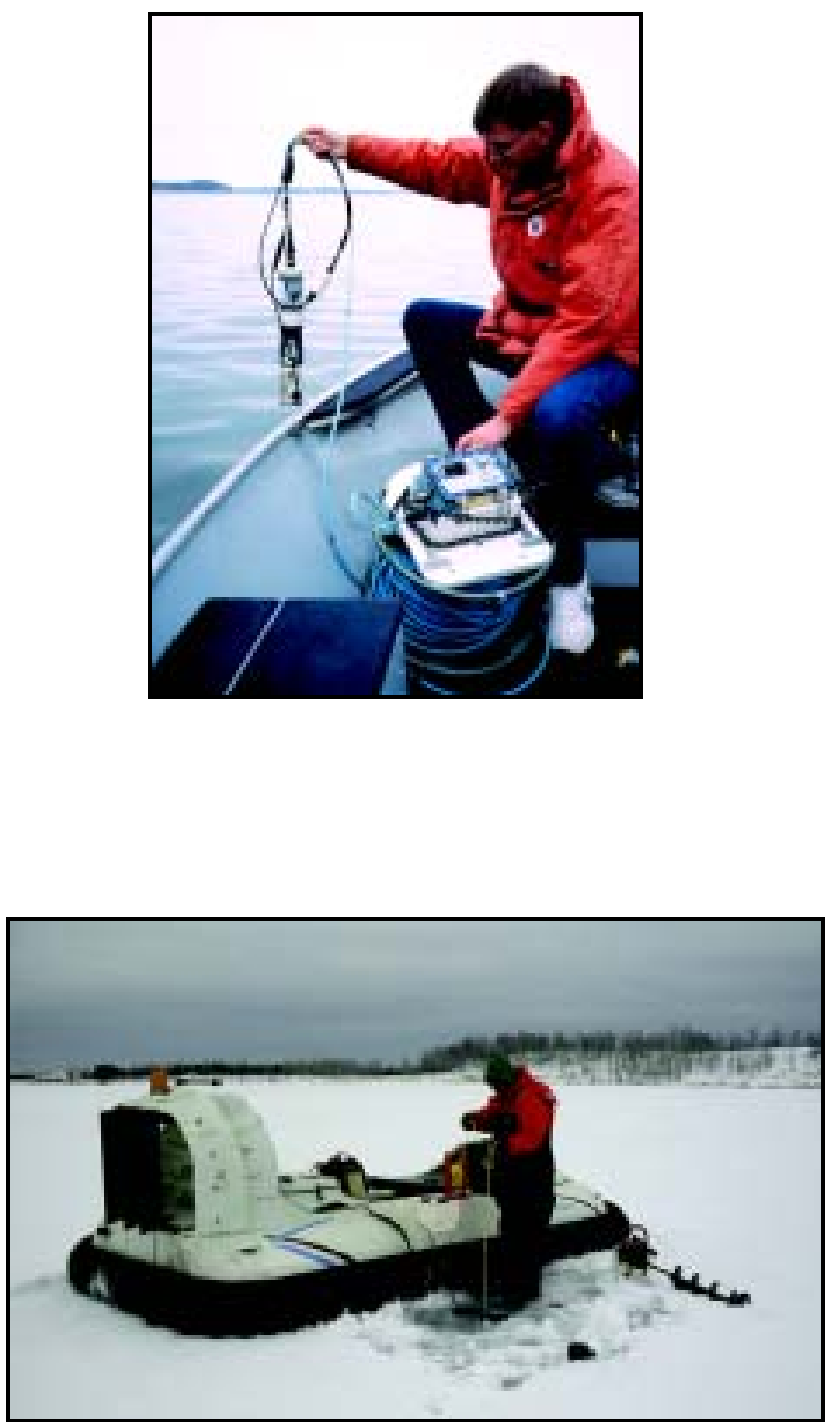


\section{PROJECTS}

Lake water-quality monitoring, chemical and biological monitoring of selected lakes, WI 13300

Assessment of the hydrology and water quality of, and phosphorus loading to, Pike Lake in Washington County,

WI 17301

Miscellaneous monitoring associated with lakes, WI 17302

Wisconsin Lakes, Green Lake tributary monitoring, WI 17303

Assessment of the hydrology, water quality, and phosphorus loading of Muskellunge Lake, Vilas County, WI 17308.

Hydrologic investigation of Powell Marsh and its relation to Dead Pike Lake, WI 17309 ............................................ 71

Lauderdale Lakes restoration monitoring, WI 17310 .............................................................................................. 73

Water quality of the Red Cedar Lakes in response to hydrologic and phosphorus loading, WI 17311 ............................ 75

Assessment of phosphorus loading, winter anoxia, and stage regulation of Little St. Germain Lake, Vilas County,

WI 17313

Assessment of the water quality, hydrology, and biology of Geneva Lake, WI 17314

Determination of steamflow, phosphorus, and solids loads entering and leaving Sinissippi Lake, Dodge County,

WI 17317

Hydrodynamic data collection for the design of Mc Cook Reservoir, WI 17318.

Response of the St. Croix River pools to various phosphorus loading scenarios, WI 17319

Assessment of the hydrology, water quality, and biology of Delavan Lake, WI 18101 


\section{LAKE WATER-QUALITY MONITORING, CHEMICAL AND BIOLOGICAL MONITORING OF SELECTED LAKES}

\begin{tabular}{|l|}
\hline PROJECT CHIEF: \\
William J. Rose \\
LOCATION: \\
Selected lakes in Wisconsin \\
PROJECT NUMBER: \\
WI 13300 \\
PERIOD OF PROJECT: \\
June 1983-Continuing \\
\hline
\end{tabular}

\section{COOPERATORS:}

\section{In the 2001 water year:}

Big Cedar, Booth, Buffalo, Eagle Spring, Lac La Belle, Little Green, Lauderdale, Middle Genesee, Okauchee, Potter, Powers, and Wind Lake Districts; City of Muskego (Big Muskego and Little Muskego Lakes); townships of Sand Lake (Big Sissabagama), and Wascott (Whitefish Lake); and Village of Oconomowoc Lake (Oconomowoc Lake) and St. Croix Tribe.

\section{In the 2002 water year:}

Big Cedar, Booth, Eagle Spring, Lac La Belle, Lauderdale, Little Green, Middle Genesee, Okauchee, Potter, Powers, and Wind Lake Districts; city of Muskego (Big Muskego and Little Muskego Lakes); and village of Oconomowoc Lake (Oconomowoc Lake)

\section{PROBLEM}

Lakes are a significant and valuable resource in the State of Wisconsin and are

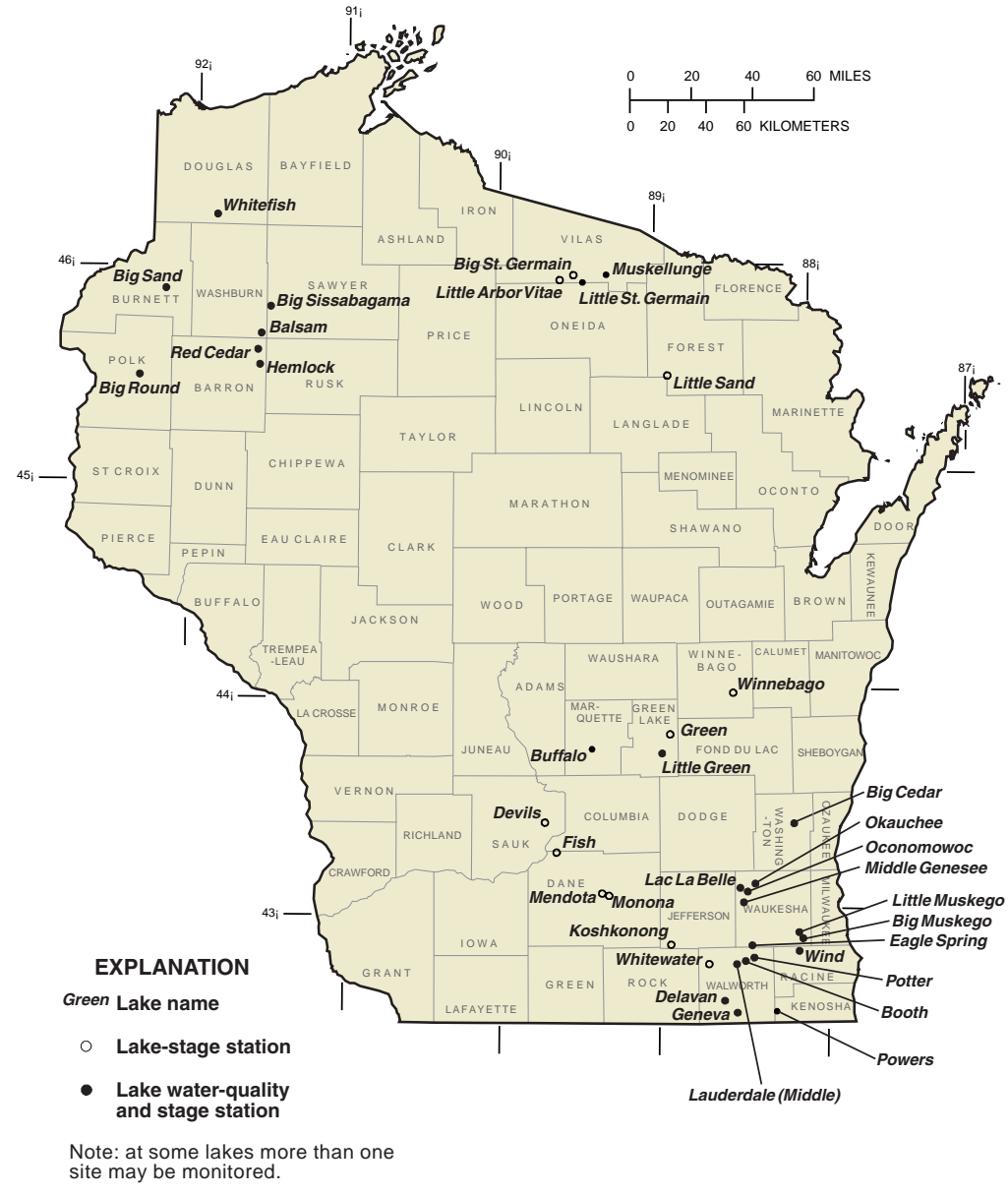

experiencing increased pressure from development and use. Many lakes do not have adequate water-quality information available for management of the lake or to assess water-quality trends. Hence, their water quality needs to be assessed and documented.

\section{OBJECTIVE}

Objectives of this project are to: (1) determine the current water quality and trophic status of lakes, (2) assess the condition of specific lakes in comparison with other lakes of the same type in the region, and (3) build a quantitative database so that any detrimental changes or trends that might occur in the future can be detected quickly and evaluated objectively. 


\section{APPROACH}

For most lakes in the program water quality will be monitored in February, April, June, July, and August. Depth profiles of dissolved-oxygen concentration, temperature, $\mathrm{pH}$, and specific conductance will be determined. In April, the lakes will be sampled for analysis of the major anions and cations, nitrogen, and dissolved phosphorus. Secchi-depth measurements will be made for all months (except February), and total phosphorus and chlorophyll $a$ samples will be collected and analyzed. Lake stage will be measured at each of the five visits to the lake. For some lakes, such as those with multiple basins, more than one site on the lake is monitored.

\section{PROGRESS (July 2001 to June 2002)}

Data were collected, published, and archived for 14 lakes during water year 2001. The locations of lakes included in the monitoring program for water years 2001-2002 are shown on the following map.

\section{PLANS (July 2002 to June 2003)}

Fourteen to sixteen lakes will be monitored in water year 2002. Data collected during the year will be compiled and transmitted to the respective cooperator. The data will be prepared for publication in the annual report "Water Quality and Lake-Stage Data for Wisconsin Lakes, Water Year 2002." 


\section{ASSESSMENT OF THE HYDROLOGY AND WATER QUALITY OF, AND PHOSPHORUS LOADING TO, PIKE LAKE IN WASHINGTON COUNTY}

\section{COOPERATOR:}

Pike Lake Management District

PROJECT CHIEF:

William J. Rose

LOCATION:

Southwestern Washington County

PROJECT NUMBER:

WI 17301

PERIOD OF PROJECT:

October 1998 to September 2002

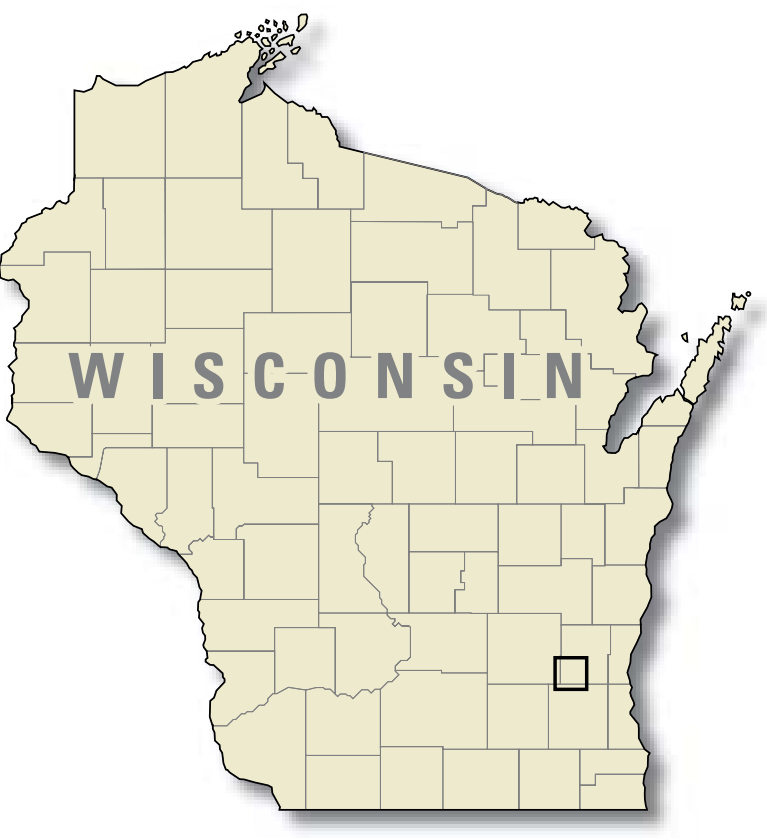

lake, assess the effectiveness of the inlet diversion and potential for improved diversion, and evaluate the effects of increases or decreases in phosphorus loading on the trophic status of the lake.

\section{APPROACH}

The study will consist of gage installation and two years of data collection followed by data analysis and report preparation. Data collection will be done from December 1998 through November 2000. Flow and water-quality data will be collected at the Rubicon River inlet to, and outlet from, the lake and at selected other inflows. These data will be used to describe the hydrology and water budget of the lake, calculate an annual phosphorus budget for the lake and evaluate effects of loading changes on the lake's trophic status. In-lake water-quality data will be provided by the Wisconsin Department of Natural Resources.

\section{PROGRESS (July 2001 to June 2002)}

Water and phosphorous budgets were computed. The Rubicon River was the dominant source of phos-

various sources and develop a phosphorus budget for the 
phorus entering the lake. However, much of that phosphorus (about 70 percent) got "short circuited" to the lake's outlet. A data summary and progress report was prepared for the lake district. Data were published in the annual report "Water Resources Data-Wisconsin."
PLANS (July 2002 to June 2003)

A report in the Water-Resources Investigations Report series will be published to describe the results of the study. 


\section{MISCELLANEOUS MONITORING ASSOCIATED WITH LAKES}

\section{COOPERATOR:}

City of Muskego

Little Muskego Lake Management

District

Whitewater/Rice Lakes

Management District

Wind Lake Management District

Town of Baraboo

\section{PROJECT CHIEF:}

William J. Rose

\section{LOCATION:}

Statewide

PROJECT NUMBER:

WI 17302

\section{PERIOD OF PROJECT:}

October 1998-Continuing

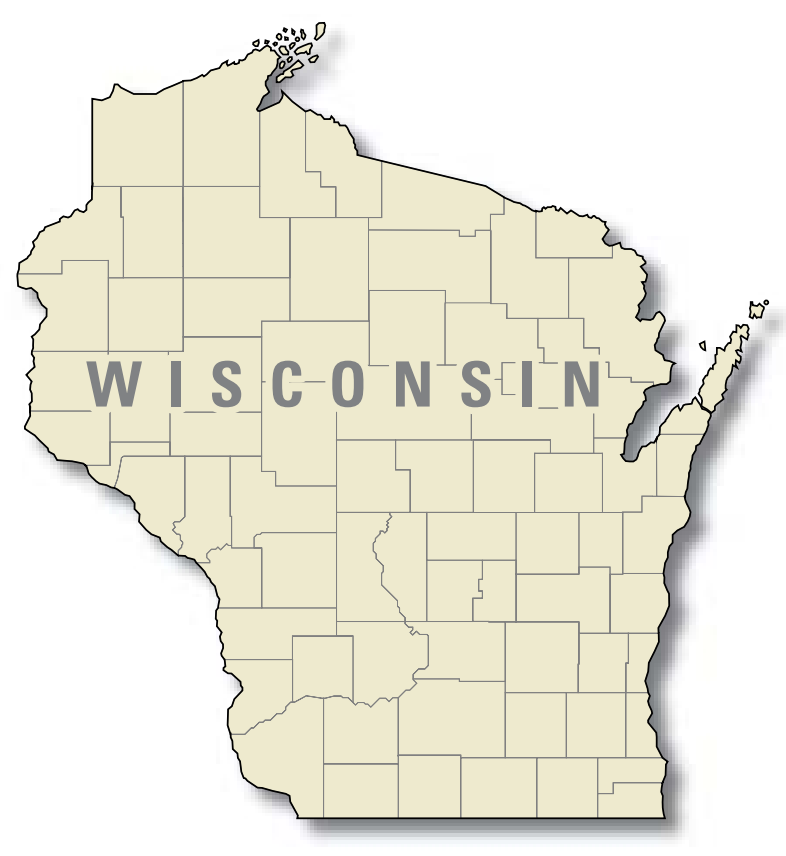

\section{APPROACH}

Monitoring that fits into this subproject will be done using appropriate standard USGS practices.

\section{PROGRESS (July 2001 to June 2002)}

Monitoring of flow, phosphorus loading, and suspended-sediment loading to Little Muskego Lake at the mouth of Jewel Creek continued. Monitoring of flow, sediment and phosphorus from Big Muskego Lake continued. Flow in a small tributory with intermittent diversions to Devil Lake was monitored. Water levels in Big Muskego, Whitwater, and Wind Lakes were monitored.

\section{PLANS (July 2002 to June 2003)}

Monitoring at last year's sites will continue. Data will be published in the annual reports "Water Resources Data-Wisconsin" and "Water-Quality and Lake-Stage Data for Wisconsin Lakes." 


\section{WISCONSIN LAKES, GREEN LAKE TRIBUTARY MONITORING}

\begin{tabular}{|l|}
\hline COOPERATOR: \\
Green Lake Sanitary District \\
PROJECT CHIEF: \\
William J. Rose \\
LOCATION: \\
Green Lake County \\
PROJECT NUMBER: \\
WI 17303 \\
PERIOD OF PROJECT: \\
October 1977-Continuing
\end{tabular}

\section{PROBLEM}

Silver Creek is the primary source of phosphorus to Green Lake. Continued documentation of suspended sediment and phosphorus loads from major tributaries helps to explain the lake's water quality. Data are needed to determine changes in loads over time and loading variability in relation to streamflow.

\section{OBJECTIVE}

The objectives of this project are to determine suspended sediment and phosphorus loads in relation to streamflow in selected tributaries to Green Lake.

\section{APPROACH}

Streamflow will be monitored continuously at selected sites. Water-sediment samples will be collected manually and by automatic samplers during storm runoff. Suspended-sediment and nutrient concentrations will be determined. Daily, monthly, and annual mean suspended-sediment and nutrient loads will be computed.

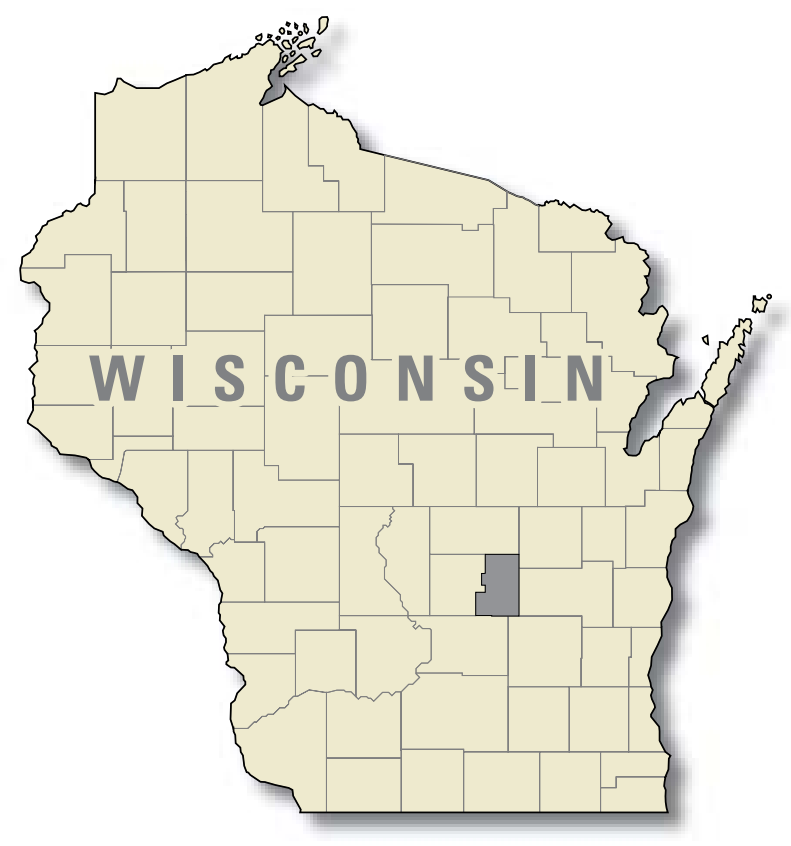

PROGRESS (July 2001 to June 2002)

Streamflow and water quality were monitored at the Silver Creek inlet to Green Lake and at the mouth of White Creek. The Silver Creek site is equipped with an acoustic velocity meter, a stage gage, and an automatic water sampler. The White Creek site is a conventional stream-gaging site and is equipped with an automatic water sampler. Streamflow, phosphorus, and suspended-sediment loading to the lake were determined for both sites.

A gage on the Puchyan River near the outlet of Green Lake was operated to monitor flow from the lake. Water samples were collected manually for phosphorus analysis. Streamflow, load and concentration data were published in the report "Water Resources Data-Wisconsin, Water Year 2001."

\section{PLANS (July 2002 to June 2003)}

Streamflow and water-quality monitoring at the Silver Creek and White Creek inlets and at the Puchyan River outlet will be continued. Streamflow, phosphorus, and suspended-sediment loads will be published in the annual report, "Water Resources Data-Wisconsin." 


\section{ASSESSMENT OF THE HYDROLOGY, WATER QUALITY, AND PHOSPHORUS LOADING OF MUSKELLUNGE LAKE, VILAS COUNTY}

\section{COOPERATOR:}

Muskellunge Lake Association

(Little St. Germain Lake District)

\section{PROJECT CHIEF:}

William J. Rose

\section{LOCATION:}

North Central Wisconsin, Vilas County

\section{PROJECT NUMBER:}

WI 17308

\section{PERIOD OF PROJECT:}

June 2000 to September 2002

\section{PROBLEM}

Members of the Muskellunge Lake Association are concerned over the perceived deteriorating water quality of the lake. Available water-quality data collected since 1973 indicate the lake is eutrophic with a possible declining trend in quality. The sensitivity of the lake's water quality to changes in nutrient loading associated with additional residential development within the lake's watershed is unknown. An understanding of the hydrology of the lake and determination of the sources and amounts of phosphorus entering and leaving the lake are needed for evaluating management alternatives and for the development of a comprehensive lake management plan.

\section{OBJECTIVE}

The objectives are to: (1) define the hydrology and water budget of Muskellunge Lake, (2) determine ground-water recharge areas for ground water discharging into the lake, (3) determine the phosphorus loads from various sources and develop a phosphorus budget

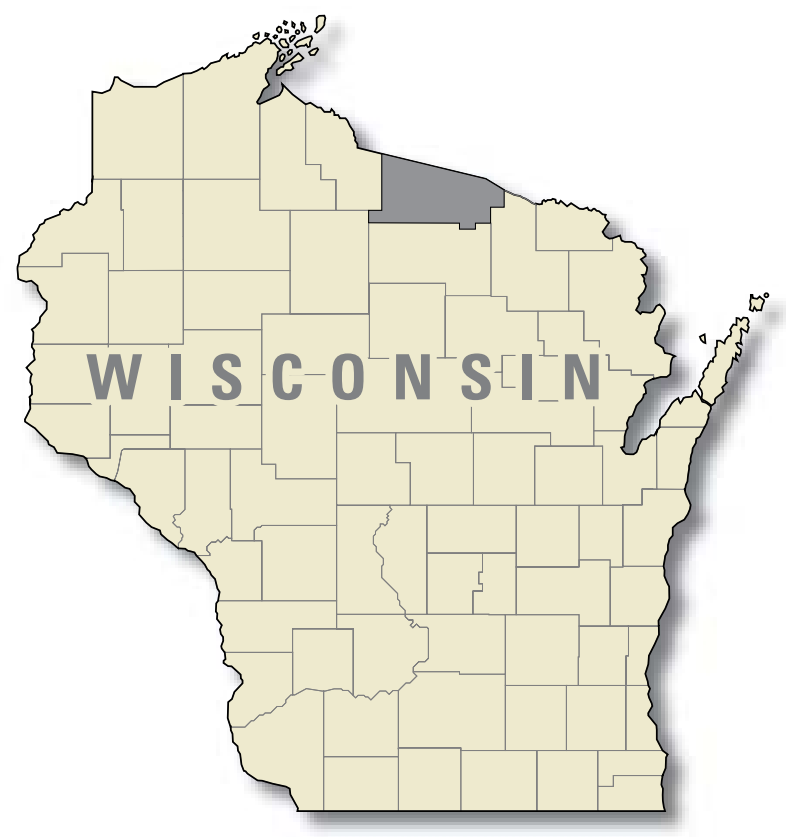

for the lake, (4) evaluate current lake water quality (trophic state) in relation to longer-term trends and to current nutrient loading from external sources, (5) evaluate the effects of incremental increases or decreases in phosphorus loading on the trophic status of the lake. These increases or decreases in loading would correspond to what might result from various development and management scenario's within the lake's watershed, and (6) determine the spatial distribution of oxygen within the lake during winter.

\section{APPROACH}

The study will consist of installation of instrumentation for data collection, data analysis and interpretation, and report preparation. Data will be collected from May 2000 through October 2001. Lake water-quality monitoring will begin in May 2000 and continue through August 2001. Instrumentation needed for the water and phosphorus budget determination will be installed in October 2000. Data collection for water and phosphorus budget determination will be for one year 
November 2000 through October 2001. Lake water quality data and water and phosphorus information will be evaluated through the use of several loading/waterquality response models in WILMS (Panuska, 2000). These models will assess the lake's sensitivity to incremental increases or decreases in phosphorus loading.

\section{PROGRESS (July 2001 to June 2002)}

All data collection for the study were completed November 30, 2001. Data were archived and published in the Wisconsin District's two annual data reports.

\section{PLANS (July 2002 to June 2003)}

Data from the study will be interpreted and reported in a U.S. Geological Survey Water-Resources Investigations Report.

Muskellunge Lake,

March 2001 vs. March 2002

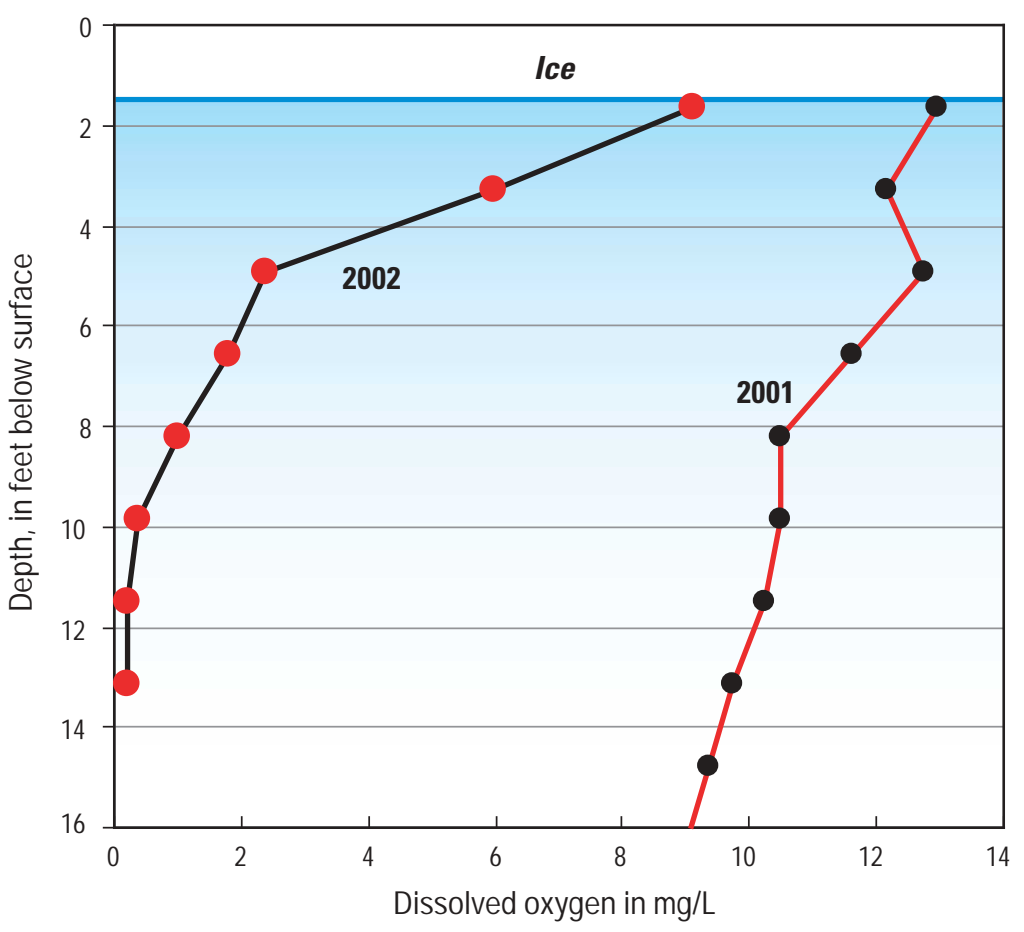

Dissolved oxygen concentrations under the ice in Muskellunge Lake during a winter with aeration (2001) and a winter without aeration (2002). 


\section{HYDROLOGIC INVESTIGATION OF POWELL MARSH AND ITS RELATION TO DEAD PIKE LAKE}

\begin{tabular}{|l|}
\hline COOPERATOR: \\
Wisconsin Department of Natural \\
Resources \\
PROJECT CHIEFS: \\
William J. Rose \\
James T. Krohelski \\
LOCATION: \\
Vilas County \\
PROJECT NUMBER: \\
WI 17309 \\
PERIOD OF PROJECT: \\
May 2000 to July 2002 \\
\hline
\end{tabular}

\section{PROBLEM}

An extensive system of ditches and shallow ponds was constructed in Powell Marsh in the 1950s. The marsh is a large part of Dead Pike Lake's watershed. Lake-area residents are concerned that the ditch and pond system has fostered the production of an iron precipitate and is damaging the aesthetic quality of the lake. The hypothesis is that iron, which is likely to be present in wetland soils, is being mobilized by anoxic conditions and locally increased ground-water gradients due to ditch and pond construction. Once the reduced iron reaches the main ditch draining to Dead Pike Lake, the iron is oxidized, forming the precipitate.

\section{OBJECTIVE}

The objectives are to: (1) identify the chemistry (parameters that govern iron) of water at various points in the marsh, pond, aquifer, ditch, and lake system, (2) define the hydrology of the pond, marsh, aquifer, ditch, and lake system, and (3) determine the effects of lowering ground-water gradients near the ditch conveying the iron precipitate to Dead Pike Lake.

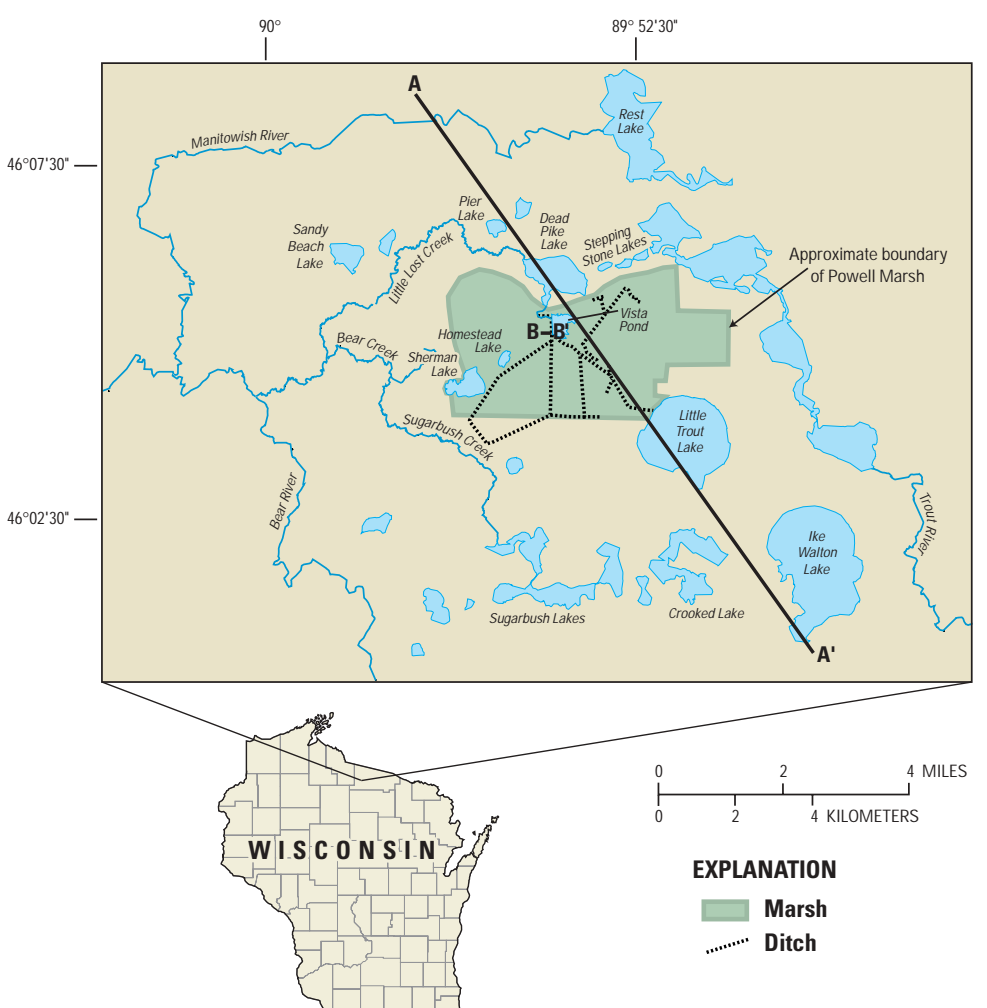

\section{APPROACH}

A first phase of the study will consist of reconnaissance, identification of site chemistry, monitoring, and development of a ground- water-flow model. The second phase will consist of monitoring, and model calibration and prediction. At the conclusion of the first phase, a meeting will be held with WDNR personnel and interested lake-area residents to explain study findings and plans for the second phase. The second phase will include a report describing findings and results of model prediction. The model will be available to WDNR and the USGS, if required, will answer requests for additional model runs.

\section{PROGRESS (July 2001 to June 2002)}

The final interpretive report for the study has been completed, approved, and published.

\section{PLANS}

Project is completed. 


\section{REPORT}

Krohelski, J.T., Rose, W.J., and Hunt, R.J., 2002, Hydrologic investigations of Powell Marsh and its relation to Dead Pike Lake, Vilas County, Wisconsin: U.S. Geological Survey Water-Resources Investigations Report 024034, $20 \mathrm{p}$.

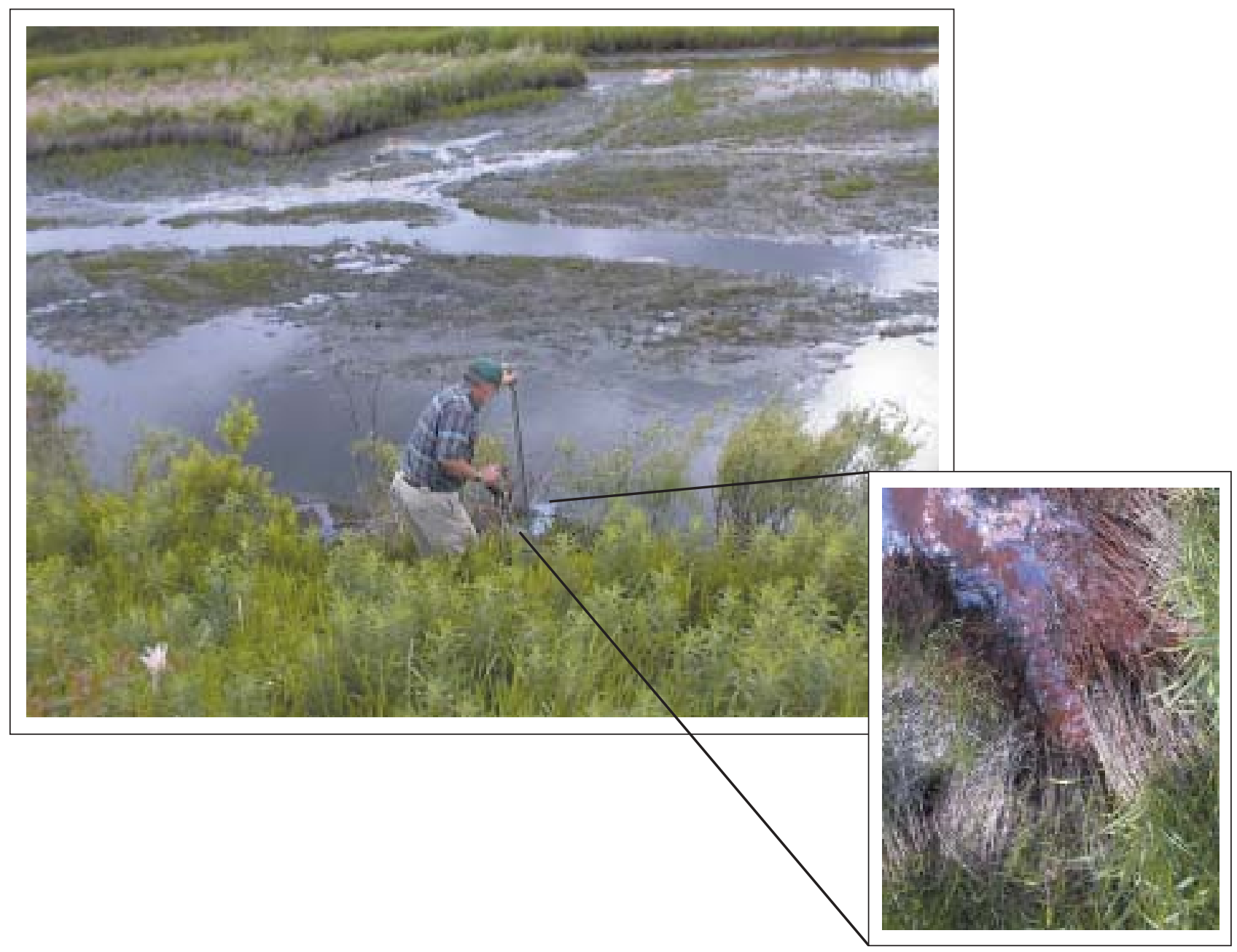




\section{LAUDERDALE LAKES RESTORATION MONITORING}

\author{
COOPERATOR: \\ Lauderdale Lakes Lake \\ Management District \\ PROJECT CHIEF: \\ Herbert S. Garn

\section{LOCATION:} \\ Walworth County \\ PROJECT NUMBER: \\ WI 17310

\section{PERIOD OF PROJECT:} \\ October 1998 to September 2002
}

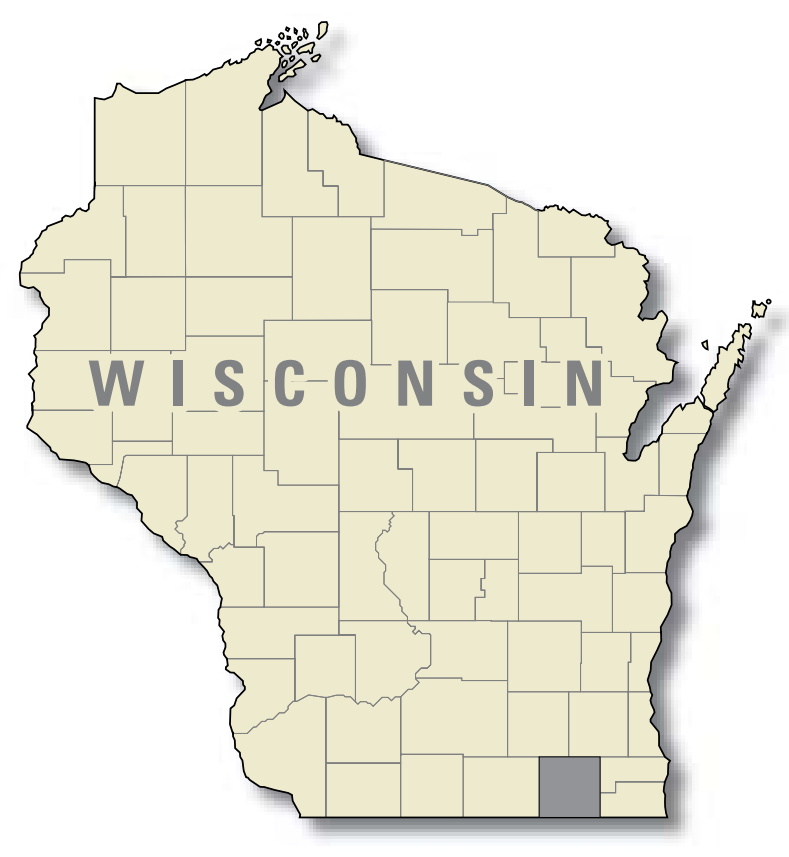

be installed around the lakes to improve runoff water quality. Water-monitoring efforts include: (1) monitoring continuous discharge, total phosphorus and solids loads from an ephemeral tributary to Green Lake that will be receiving treatments to improve runoff quality, (2) monitoring in-lake water quality of Middle Lake to describe and quantify lake water quality during the restoration period, and (3) monitoring surface runoff from representative lawns around Lauderdale Lakes and determining the effect of various lawn fertilizing practices on phosphorus content of lawn runoff. Use of regular fertilizer, use of non-phosphorus fertilizer, and no fertilizer application are the practices that will be evaluated.

\section{PROGRESS (July 2001 to June 2002)}

Lawn runoff monitoring was conducted at 16 sites during the growing season to determine nutrient content; two seasons of lawn monitoring were completed on September 30, 2001. A total of 23 runoff events were sampled over the two seasons and total phosphorus concentrations observed in lawn runoff samples had maxi- 
mums greater than $15 \mathrm{mg} / \mathrm{L}$. Lawn fertilizer applications did not affect nitrogen concentrations in runoff, but did affect phosphorus concentrations. Lawn sites with regular fertilizer applications had median phosphorus concentrations in lawn runoff that were greater than those from nonphosphorus fertilizer sites and unfertilized sites. Phosphorus concentrations in runoff from nonphosphorus-fertilizer sites were similar to those from unfertilized sites. Streamflow gaging and water-quality monitoring of the ephemeral tributary on the northeast side of Green Lake, and water-quality monitoring of Middle Lake were also completed on September 30, 2001. All data were reviewed for the water year and published in the annual data report series
"Water Resources Data-Wisconsin" and in the lake data report for Water Year 2001. A report was prepared presenting the results of nutrient concentrations in runoff from lawn sites adjacent to Lauderdale Lakes.

\section{PLANS (July 2002-June 2003)}

Project is completed.

\section{REPORTS}

Garn, H.S., 2002, Effects of lawn fertilizer on nutrient concentration in runoff from lakeshore lawns, Lauderdale Lakes, Wisconsin: U.S. Geological Survey WaterResources Investigations Report 02-4130, 6 p. 


\section{WATER QUALITY OF THE RED CEDAR LAKES IN RESPONSE TO HYDROLOGIC AND PHOSPHORUS LOADING}

\section{COOPERATOR:}

Town of Cedar Lake

PROJECT CHIEFS:

Dale M. Robertson

William J. Rose

\section{LOCATION:}

Washburn and Barron Counties

PROJECT NUMBER:

WI 17311

PERIOD OF PROJECT:

September 2000 to December 2002

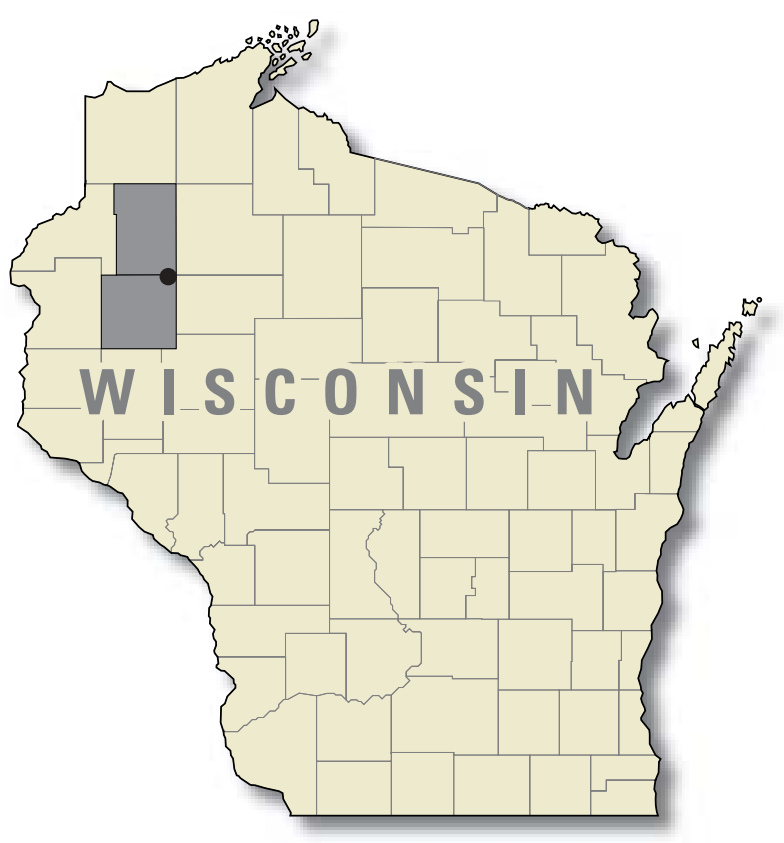

\section{APPROACH}

Water quality will be sampled 6 times/year in Balsam, Hemlock, and Red Cedar Lakes. To estimate the nutrient loading at Birch Lake Outlet and Red Cedar Outlet, daily streamflow will be measured and samples will be collected 12 to 15 times per year. To estimate nutrient loading from direct tributaries loading, two sites (Hemlock Creek and Sucker Creek) will have automated recording gages installed and will be sampled with automatic water samplers. Phosphorus load data at the stream sites will be used to estimate unit-area loads for unmonitored portions of the basins. These data will be used to develop complete hydrologic and phosphorus budgets for each lake. Concurrent water and phosphorus budgets for the lakes and in-lake waterquality data will be used to calibrate BATHTUB for the lakes. The BATHTUB model will be used to estimate the response of each of the lakes to various phosphorusloading scenarios. contributions of phosphorus from critical locations and the response of the lakes to various scenarios will help in the development of a lake-management plan for the Red Cedar Lakes. 


\section{PROGRESS (July 2001 to June 2002)}

All flow and water-quality data were collected and loads were computed from all gaged sites. Complete loading from the watershed was estimated. Stream data were compiled and published in the report "Water Resources Data-Wisconsin, Water Year 2001." Lake data were compiled and published in "Water-Quality and Lake-Stage Data for Wisconsin Lakes, Water Year 2001."

\section{PLANS (July 2002 to June 2003)}

The BATHTUB model will be developed for the system and used to determine the response of each lake to changes in nutrient loading. A summary report will be prepared and published.

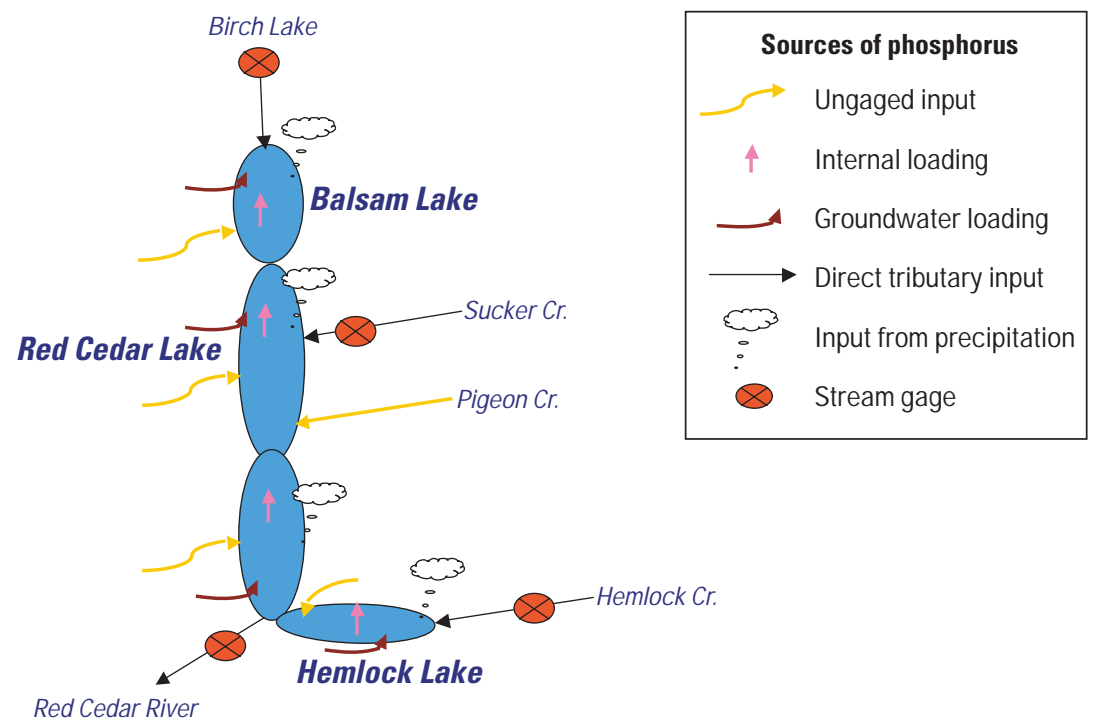

Schematic for BATHTUB model for the Red Cedar Lakes 


\section{ASSESSMENT OF PHOSPHORUS LOADING, WINTER ANOXIA, AND STAGE REGULATION OF LITTLE ST. GERMAIN LAKE, VILAS COUNTY}

\section{COOPERATOR:}

Little St. Germain Lake District

PROJECT CHIEFS:

William J. Rose

Dale M. Robertson

\section{LOCATION:}

10 miles west of Eagle River

PROJECT NUMBER:

WI 17313

\section{PERIOD OF PROJECT:}

August 1996 to June 2001

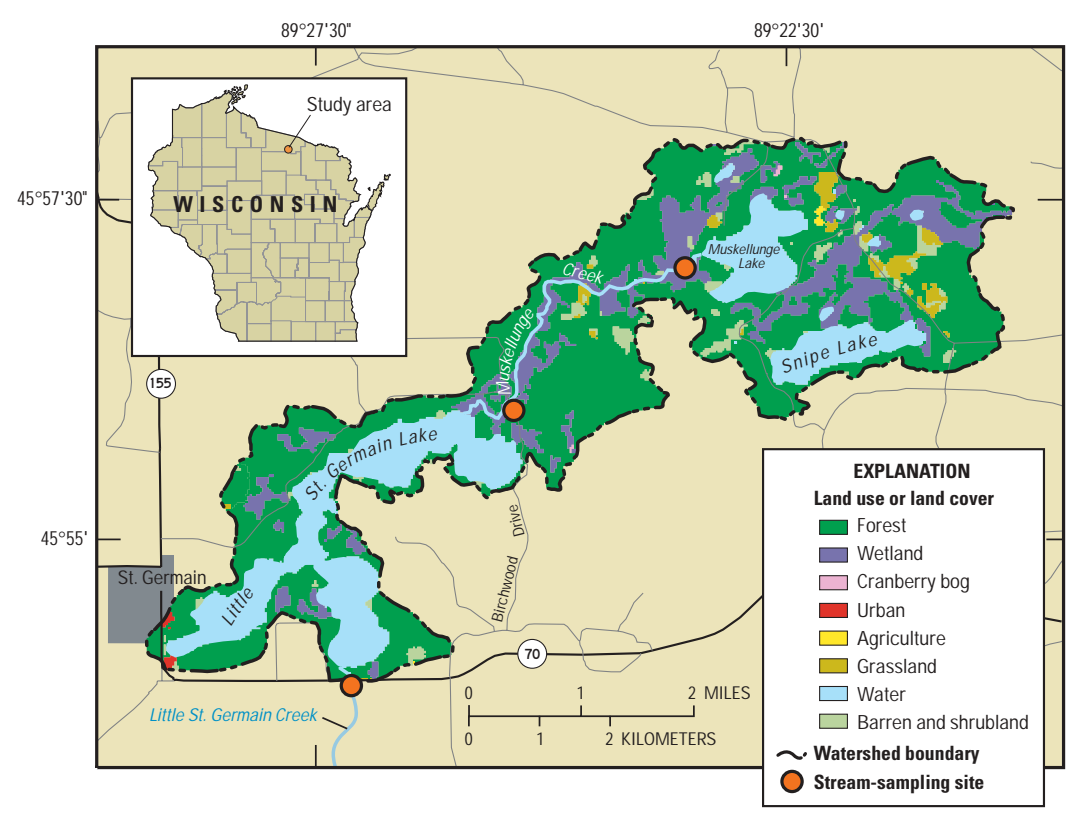

\section{PROBLEM}

Little St. Germain Lake consists of four main basins (East Bay, Upper East Bay, South Bay, and West Bay) separated by narrows. Muskellunge Creek, the lake's only inlet stream, enters East Bay. A dam at the lake's outlet is used to regulate lake stage and flow from South Bay. Hence, the net flow of water is from East Bay to South Bay. Summer water quality ranges from good to very good in the West Bay, fair to good in the South Bay, and poor to very poor in the East Bay, based on monitoring from 1992-1994. Dissolved oxygen was absent at the South Bay monitoring site in late winter each year from 1992-1994. The areal extent and cause of the oxygen problem was identified in studies from 1994-2000. The Lake District is considering various measures to improve lake water quality. These include aeration of Upper East and South Bays in winter and possible treatment of Muskellunge Creek water before it enters the lake.

\section{OBJECTIVE}

The primary objectives of this project are to: (1) continue the water-quality trend monitoring at sites in the four main basins of the lake, (2) continue monitoring to determine water and phosphorus loading to the lake from Muskellunge Creek, (3) identify sources of phosphorus to Muskellunge Creek, (4) determine spatial and temporal distribution of oxygen in winter before and after installation of aeration systems, (5) model ground-water/lake-water interaction and estimate loading of phosphorus to lake from ground water, and (6) synthesize all data, new and old, to evaluate the effectiveness of aeration systems and refine lake water and phosphorus budgets.

\section{APPROACH}

The Lake's water and phosphorus budgets will be defined to better resolution than in previous studies. In particular, ground-water inflow and outflow will be quantified through modeling aided by data from piezometers installed around the lake's perimeter. Determination of inflow to the lake from Muskellunge Creek will be improved by the operation of a continuous stage monitor. Measurements of flow and phosphorus concentration will be made at three locations along Muskellunge Creek to identify general source areas for phosphorous. Phosphorus loading from ground water 
will be based on data from sampled near-lake piezometers and inflow estimates generated by the groundwater model (GFLOW). Lake-water quality trend monitoring will continue at the four main basins of the lake. Measurements will be made to determine the spatial and temporal distribution of oxygen in winter before and after installation of aeration systems. All new and old data will be synthesized to evaluate the effectiveness of the aerations systems and to refine lake water and phosphorus budgets.

\section{PROGRESS (July 2001 to June 2002)}

Data monitoring continued as scheduled. The Lake District installed aerators in the Upper East Bay and Northeast Bay.

\section{PLANS (July 2002 to June 2003)}

A third aerator will be installed in the South Bay. Monitoring will continue as scheduled.

\section{REPORTS}

Robertson, D.M. and Rose, W.J., 2000, Hydrology, water quality, and phosphorus loading of Little St. Germain Lake, Vilas County, Wisconsin: U.S. Geological Survey Water-Resources Investigations Report 00-4209, 8 p.
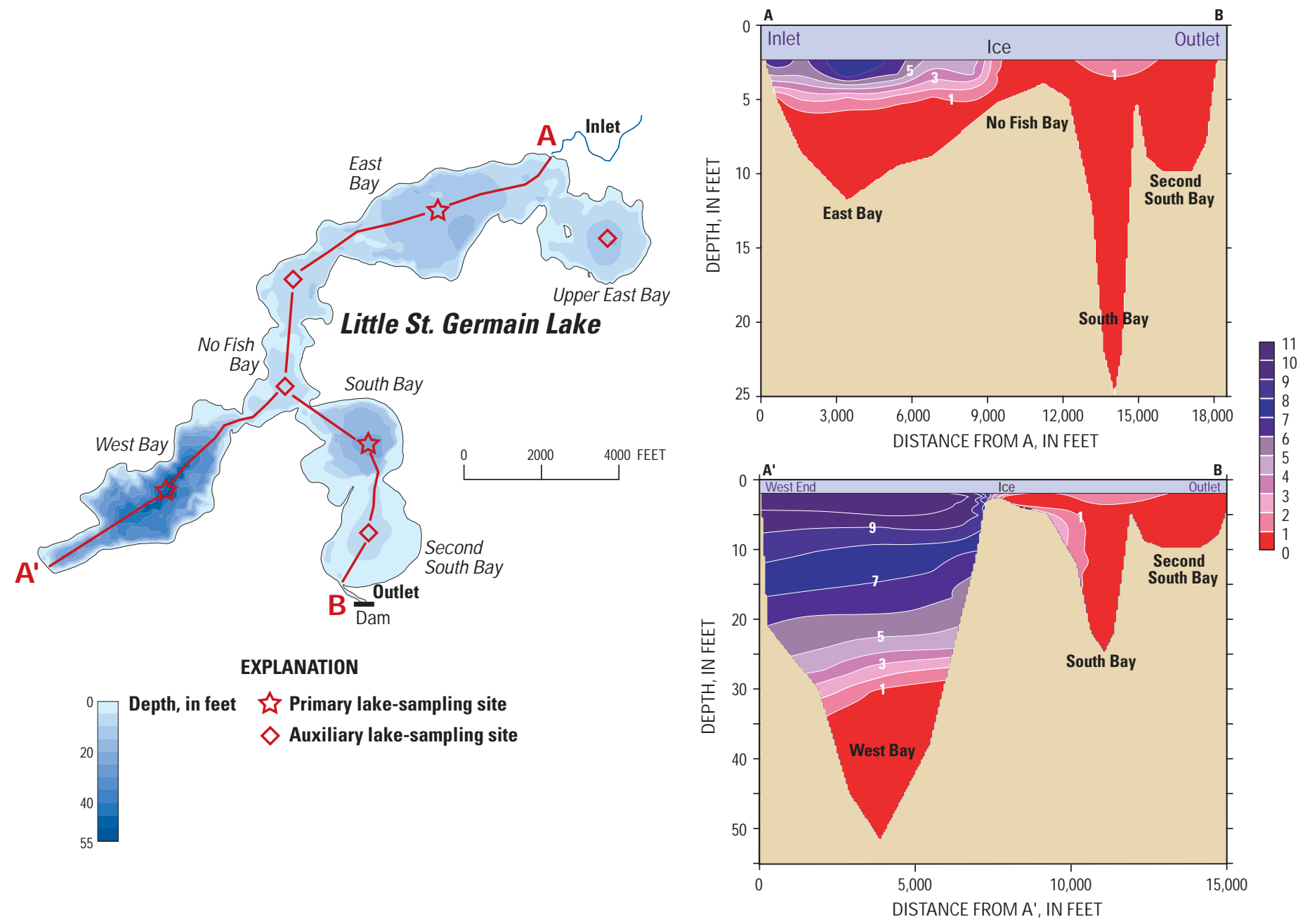

Distribution of dissolved oxygen under the ice in Little St. Germain Lake, Wis., March 18, 1997. 


\section{ASSESSMENT OF THE WATER QUALITY, HYDROLOGY, AND BIOLOGY OF GENEVA LAKE}

\begin{tabular}{|l|}
\hline COOPERATOR: \\
Geneva Lake Environmental \\
Agency \\
LOCATION: \\
Walworth County \\
PROJECT NUMBER: \\
WI 17314 \\
PROJECT CHIEF: \\
Dale M. Robertson \\
PERIOD OF PROJECT: \\
March 1997-Continuing \\
\hline
\end{tabular}

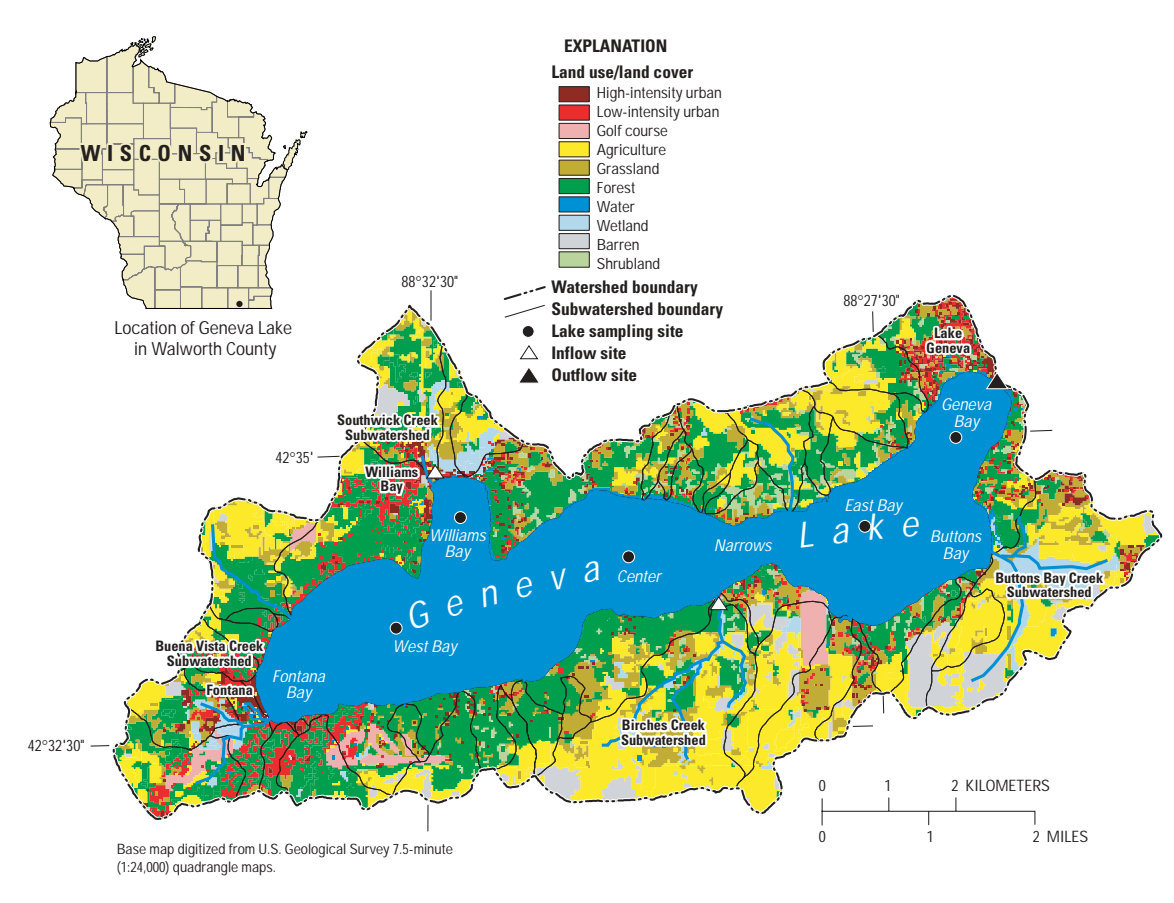

\section{PROBLEM}

Concerns have arisen over the potential decline in the water quality of Geneva Lake because of increased urban development and recreational use. The public perception is that the water quality of Geneva Lake is declining; however, little direct evidence is available to support or deny the perceptions. To reduce the impact on the lake, efforts are being made to decrease the point and nonpoint-source pollution to the lake. However, more water-quality and biological information are needed to determine which pollution prevention strategies will be most cost effective.

\section{OBJECTIVES}

The objectives of this project are to: (1) document the water quality and planktonic populations in the lake, (2) estimate phosphorus and sediment loading to the lake, (3) determine the historical water quality of the lake by examining lake sediments, and (4) construct hydrologic and phosphorus budgets for the lake.

\begin{abstract}
APPROACH
Phosphorus and streamflow were monitored at two locations upstream of Geneva Lake and at the outlet from which loads of phosphorus to and from the lake were estimated. Water quality and plankton populations were monitored from 1997 to the present. Nutrient and phosphorus budgets will be constructed for the lake. Sediment cores will be analyzed to estimate sedimentation rates and the historical water quality of the lake. Eutrophication models will be used to evaluate various nutrient load scenarios.
\end{abstract}

\section{PROGRESS (July 2001 to June 2002)}

Lake sampling continued at the deep hole in the West Basin. Lake data were compiled for publication in the report, "Water Resources Data-Wisconsin, Water Year 2001" and "Water-Quality and Lake-Stage Data for Wisconsin Lakes, Water Year 2001." A phosphorus budget was constructed for the lake. Nutrient load reduction scenarios were modeled for the lake using WILMS. A dynamic model was configured for the lake and used to estimate evaporation and examine changes 
in dissolved oxygen concentrations. Sediment cores were analyzed and the results were published. A WaterResources Investigations Report was published summarizing the results of the project.

\section{PLANS (July 2002 to June 2003)}

Approximately monthly lake sampling in the west bay will continue. Lake data will be continued and compiled and published in the Water Resources Data-Wisconsin reports.

\section{REPORTS}

Elder, J.F., Robertson, D.M., and Garrison, P.J., 2000, Chemical composition of surficial deposits in Geneva Lake, Wisconsin. U.S. Geological Survey Fact Sheet 121-00, $4 \mathrm{p}$.

Robertson, D.M., Goddard, G.L., Mergener, E.A., Rose, W.J., and Garrison, P.J., 2002, Hydrology and water quality of Geneva Lake, Walworth County, Wisconsin; U.S. Geological Survey Water-Resources Investigations Report 02-4039, 73 p.

\section{Inflow}

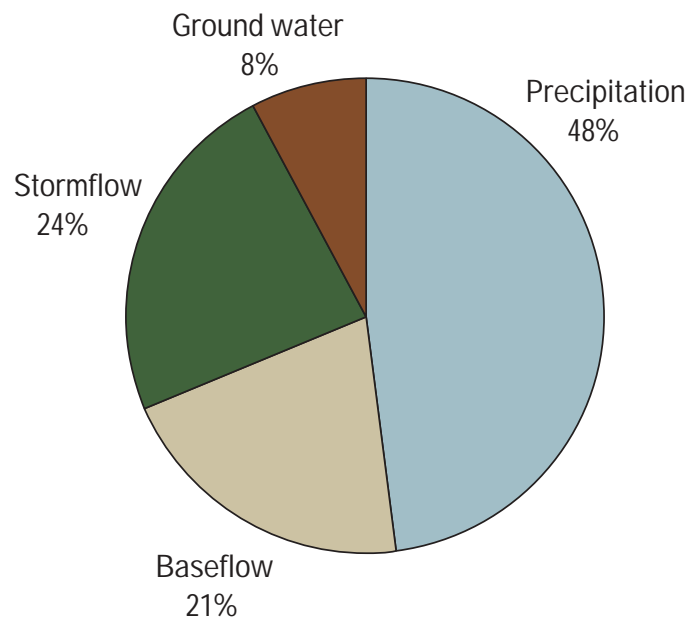

Total - 37,500,000 cubic meters
1998 - Phosphorus Input

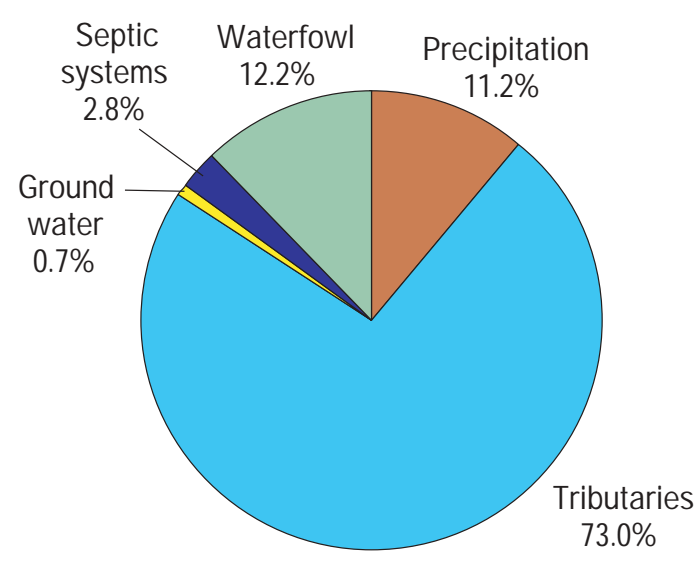

Total - 3,200 kilograms

Hydrologic and phosphorus budgets estimated for Geneva Lake during water year 1998. These data were used to develop water-quality models for the lake. 


\section{DETERMINATION OF STREAMFLOW, PHOSPHORUS, AND SOLIDS LOADS ENTERING AND LEAVING SINISSIPPI LAKE, DODGE COUNTY}

\author{
COOPERATOR: \\ Village of Hustisford \\ PROJECT CHIEF: \\ David J. Graczyk \\ LOCATION: \\ Central Dodge County \\ PROJECT NUMBER: \\ WI 17317

\section{PERIOD OF PROJECT:} \\ December 2001 to September 2003
}

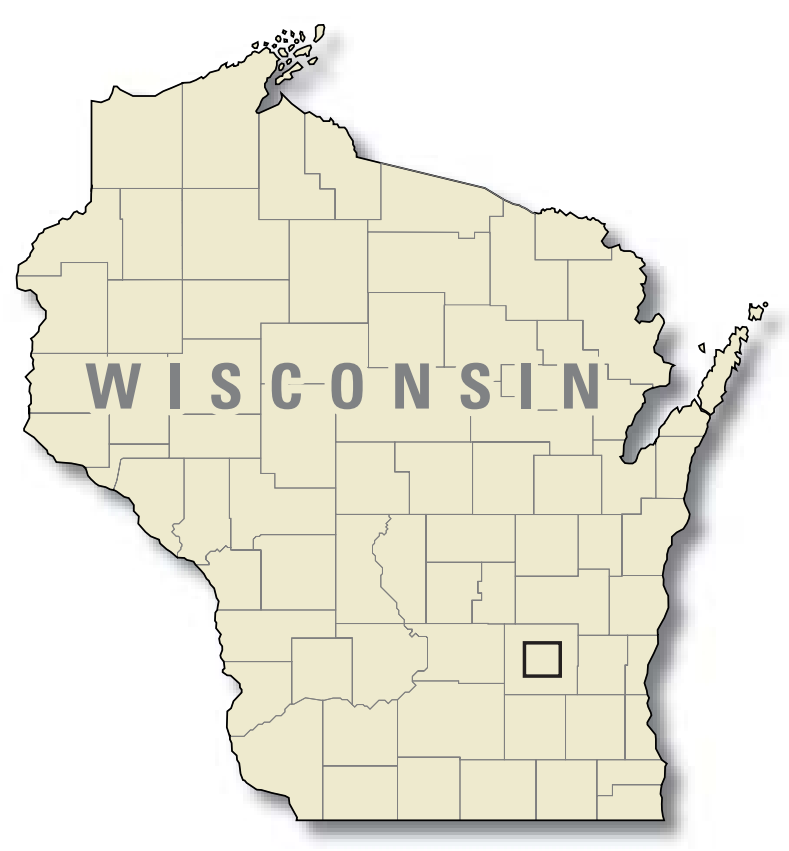

\begin{abstract}
APPROACH
Streamflow, phosphorus, and suspended-solids load monitoring will be done at Rock River at Horicon and Hustisford and Dead Creek near Hustisford. A stream gage, employing conventional stage-discharge rating techniques will be installed at Rock River at Hustisford. The Rock River at Horicon and Dead Creek near Hustisford will be equipped with an acoustic velocity meter (AVM) gage because flat gradients preclude conventional gaging. Samples will be collected by an automatic sampler at Dead Creek and by manual sampling at the two Rock River sites. Loads will be calculated using streamflow-concentration-integration techniques.
\end{abstract}

\section{PROGRESS (July 2001 to June 2002)}

The objective of this project is to provide a quantitative understanding of solids and phosphorus loads entering Sinissippi Lake from the Rock River at Horicon and Dead Creek, and leaving Sinissippi Lake at the outlet in Hustisford.
Monitoring sites were installed at the three sites. The monitoring sites are: 05424057 Rock River at Horicon, 05424075 Dead Creek at Arrowhead Trail near Hustisford, and 05424082 Rock River at Hustisford. All 
stations were installed and operational on December 1 , 2001. Water-quality samples were collected at each of the sites during non-event periods on a bi-weekly and monthly schedule (winter periods). Water samples were collected more frequently during runoff events.

\section{PLANS (July 2002 to June 2003)}

Monitoring of the sites will continue through the 2002 water year and continue through November 2002. Daily streamflow, total phosphorus and suspended solids loads will be calculated. All data will be published in the annual data report "Water Resources Data-Wisconsin, Water Year 2002." 


\section{HYDRODYNAMIC DATA COLLECTION FOR THE DESIGN OF MC COOK RESERVOIR}

\section{COOPERATOR:}

U.S. Army Corps of Engineers

\section{PROJECT CHIEFS:}

Dale M. Robertson

Gary P. Johnson

\section{LOCATION:}

Chicago, Illinois; Urbana, Illinois; and Snake River, Washington

\section{PROJECT NUMBER:}

WI 17318

\section{PERIOD OF PROJECT:}

1994-Continuing

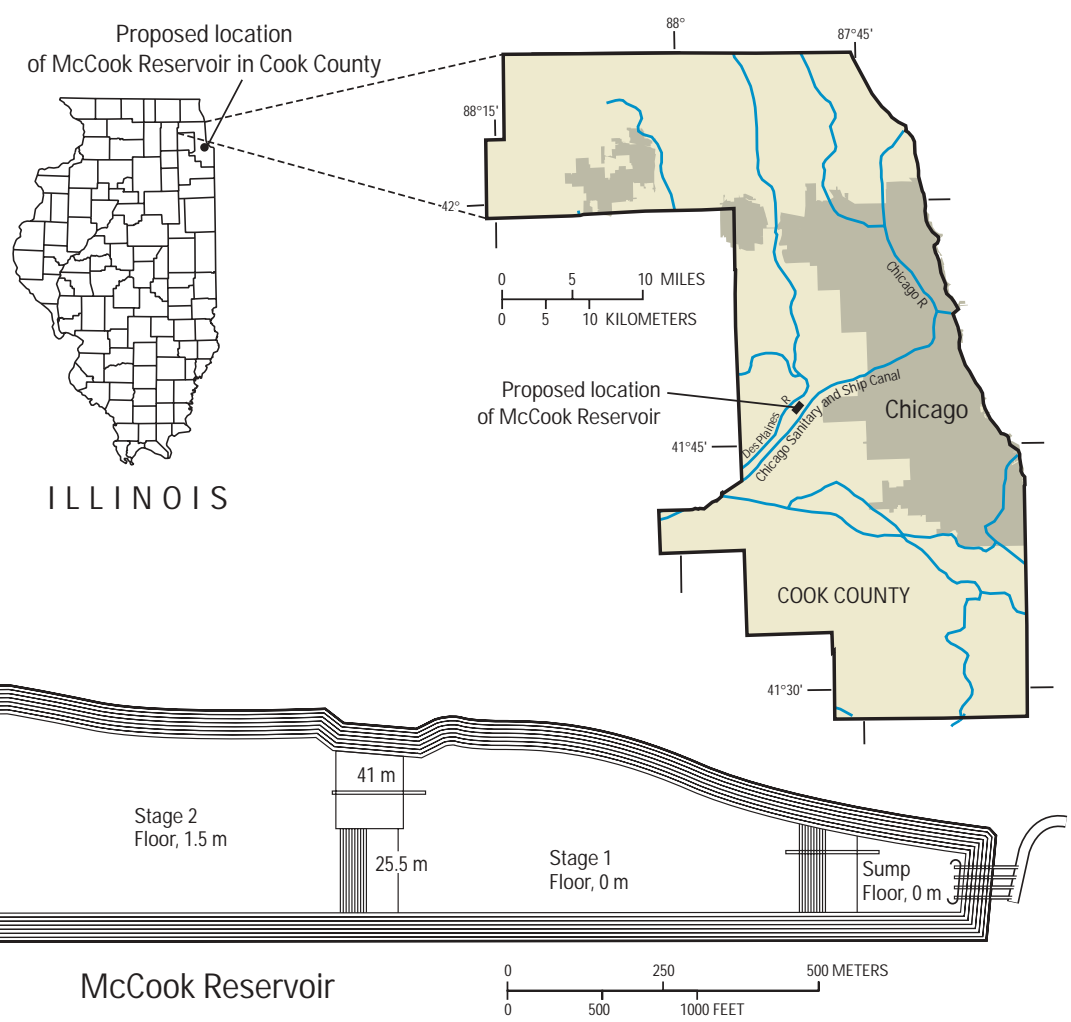

\section{PROBLEM}

The U.S. Army Corps of Engineers is designing a flood-control reservoir (McCook Reservoir) to store excess stormwater and sewage from combined sewer overflows (CSO's) as part of the Chicagoland Underflow Plan/Tunnel and Reservoir Plan. During storm events, CSO's will be diverted through dropshafts into a series of deep tunnels and into the reservoir. The CSO's will be stored in the reservoir until the water can be treated. A coarse-bubble aeration system is being designed by the Corps to prevent stratification and anoxic conditions from developing in the reservoir. Submersible mixers, surface mixers, and/or other devices may also be required to enhance water movement in the reservoir. The aeration/mixing system will be designed based on results from simulations of a finite-volume numerical model being developed by the Corps for simulating three-dimensional incompressible flow extended to compute the flow produced by bubble aerators. To test the ability of the model to help design the aeration/mixing system, hydrodynamic data are needed to help verify the accuracy of the model.

\section{OBJECTIVES}

The objectives of this project are to: (1) collect hydrodynamic data (velocity and mixing patterns) from laboratory tanks, and shallow (Egan Quarry, Ill.) and deep (Lower Granite Lock on the Snake River, Wash.) systems, (2) test some of the assumptions used in the three-dimensional model, and (3) review the design reports and model simulations by the Corps.

\section{APPROACH}

The general approach in this project is to collect data to demonstrate mixing patterns (velocity data with acoustic doppler velocimeters and acoustic doppler current profilers augmented with dyes and water-quality data) in laboratory tests at the U.S. Army Corps of Engineers, Waterways Experiment Station, Miss. and at Urbana, Ill., in a shallow lake (Egan Quarry, Ill.), and in 
a deep system (Lower Granite Lock on the Snake River, Wash.). One-dimensional aeration models will be applied in the shallow and deep systems to aid in choosing sites for data collection. These data will be used by the Corps to evaluate the accuracy of their three-dimensional model. One-dimensional aeration models will also be applied to test some assumptions required in modeling the mixing in McCook Reservoir. Data will also be collected in the deep system to determine the rate of oxygen transfer from the bubbles in the aeration system.

\section{PROGRESS (July 2001 to June 2002)}

Tests at the Waterways Experimental Station and in Egan Quarry were completed in previous years. Experiments in the test tank in Urbana were run and will continue. The final site for the deep water experiments was chosen at the Lower Granite Lock on the Snake River, Wash.

\section{PLANS (July 2002 to June 2003)}

Experiments in the test tank in Urbana will be completed. All deep-water experiments will be designed and conducted (sampling planned during February and March, 2003).

\section{REPORTS}

Johnson, G.P., Hornewer, N.J., Robertson, D.M., and Olson, D.T., 2000, Methodology, data collection, and data analysis for determination of water-mixing patterns induced by aerators and mixers: U.S. Geological Survey Water Resources Investigations Report 00-4101, 72 p.

Robertson, D.M., 2000, One-dimensional simulation of stratification and dissolved oxygen in McCook Reservoir, Illinois: U.S. Geological Survey Water Resources Investigations Report 00-4258, 17 p.

Hornewer, N.J., Johnson, G.P., Robertson, D.M., and Hondzo, M., 1997, Field-scale tests for determining mixing patterns associated with coarse-bubble air diffuser configurations, Egan Quarry, Illinois, in Environmental and Coastal Hydraulics: Protecting the Aquatic Habitat, Proceedings of the International Association of Hydraulic Research, San Francisco, Calif., USA, p. 57-63.
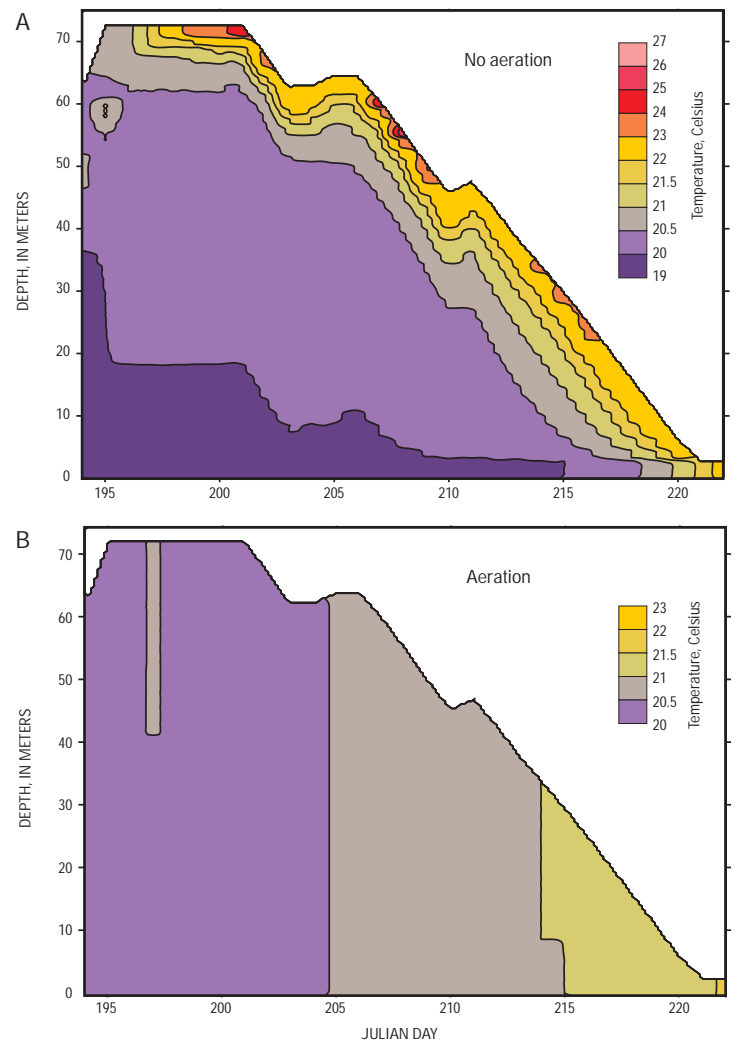

Simulated water temperature distribution in McCook Reservoir, Illinois, with and without aeration. 


\section{RESPONSE OF THE ST. CROIX RIVER POOLS TO VARIOUS PHOSPHORUS LOADING SCENARIOS}

\begin{tabular}{l} 
COOPERATOR: \\
Wisconsin Department of Natural \\
$\quad$ Resources \\
PROJECT CHIEFS: \\
Dale M. Robertson \\
Bernard N. Lenz \\
LOCATION: \\
St. Croix National Scenic Riverway \\
PROJECT NUMBER: \\
WI 17319 \\
PERIOD OF PROJECT: \\
December 2001 to September 2002 \\
\hline
\end{tabular}

\section{PROBLEM}

The St. Croix National Scenic Riverway, Wisconsin and Minnesota, is one of the original eight components of the National Wild and Scenic Rivers Act. Due to the proximity of this area to the Minneapolis/St. Paul, Minnesota metropolitan area, the Riverway has experienced increased use and developmental pressure. Several pools are in the lower $100 \mathrm{~km}$ of the Riverway. Presently, each of the pools in the lower reach of the Riverway is eutrophic to hypereutrophic because of high nutrient loading, primarily phosphorus loading. To protect these pools, managing agencies understand the need to limit phosphorus loading to the pools; however, it is not known how the pools will respond to changes in phosphorus loading.

\section{OBJECTIVE}

The objectives of this project are to calibrate and apply the BATHTUB model to the St. Croix River pools to provide a better understanding of the sensitivity and

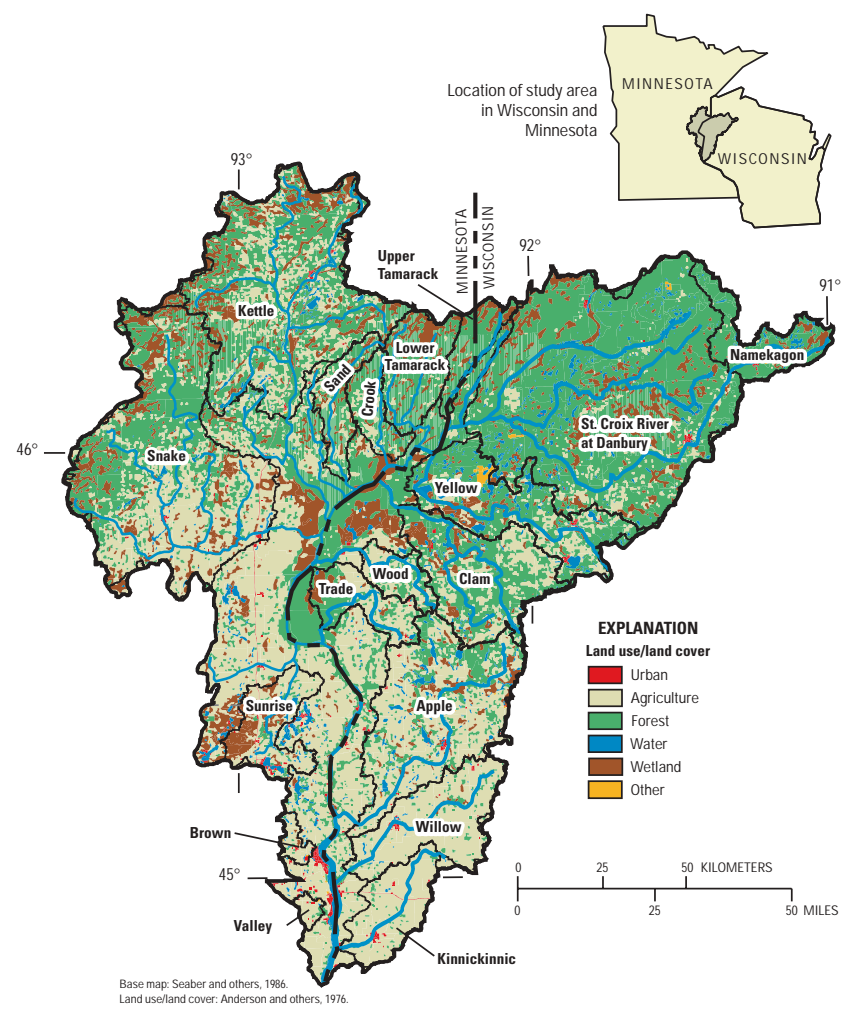

expected response of each of the pools to decreased and increased phosphorus loading. In future studies, the calibrated model can be used to evaluate the effects of specific management scenarios supplied by the Basin Team.

\section{APPROACH}

To determine the sensitivity of each of the St. Croix River pools to decreases and increases in phosphorus loading, the BATHTUB model will be calibrated using pool and tributary data collected in previous studies (WI21300: Lenz, B.N., Robertson, D.M., Fallon, J.D., and Ferrin, R., 2001, Nutrient and suspended-sediment loads and benthic invertebrate data for tributaries to the St. Croix River, Wisconsin and Minnesota, 1997-99: U.S. Geological Survey Water-Resources Investigations Report 01-4162, 57 p.). Two separate BATHTUB models will be attempted to be developed; one model for St. Croix Falls Reservoir and one for Lake Mallalieu/Lake St. Croix. Water quality in the various pools may respond differently during various flow regimes; 
therefore, sensitivity and scenario evaluations for total phosphorus and chlorophyll $a$ concentrations and water clarity will be performed for 1999, and also for a period with relatively low flows throughout the basin (using flow data from 1988) and for a period with relatively high flows throughout the basin (using flow data from 1996). During each of these flow regimes, phosphorus loading from each tributary will be estimated by use of flow-to-load relations based on 1997-99 data, and loading from other sources will be assumed to be similar to that estimated for 1999.

\section{PROGRESS (July 2001 to June 2002)}

All modeling was completed and draft of final report is in review.

\section{PLANS (July 2002 to June 2003)}

Publish final report.

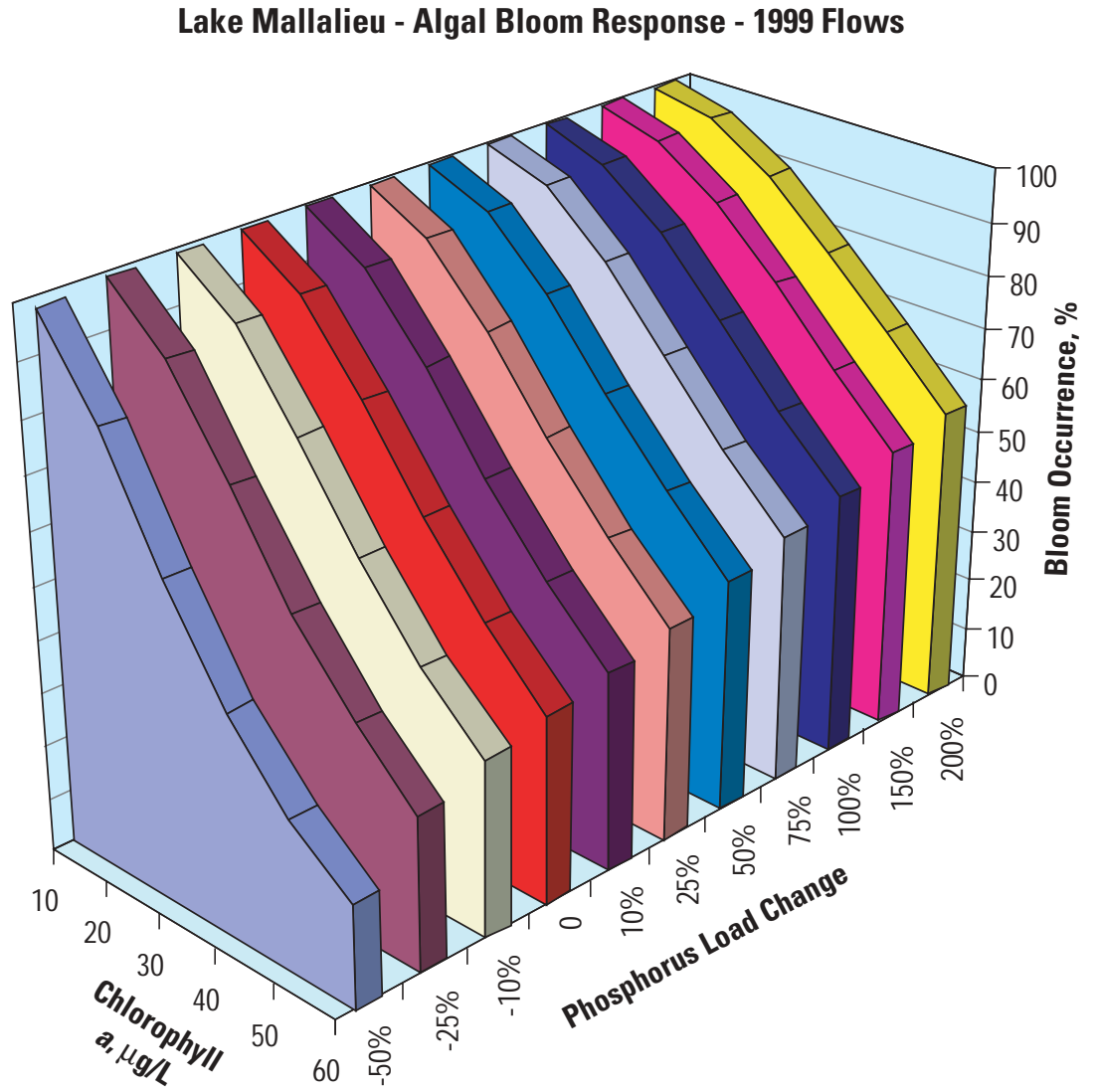

Change in the occurrence of algal blooms (percent of days from May through September) as a function of phosphorus loading and how an algal bloom is defined, on the basis of BATHTUB simulations. 


\section{ASSESSMENT OF THE HYDROLOGY, WATER QUALITY, AND BIOLOGY OF DELAVAN LAKE}

\begin{tabular}{|l|}
\hline COOPERATOR: \\
Town of Delavan \\
PROJECT CHIEFS: \\
Dale M. Robertson \\
Gerald L. Goddard \\
LOCATION: \\
Walworth County \\
PROJECT NUMBER: \\
WI 18101 \\
PERIOD OF PROJECT: \\
August 1983-Continuing \\
\hline
\end{tabular}

\section{COOPERATOR:}

Town of Delavan

PROJECT CHIEFS:

Dale M. Robertson

Gerald L. Goddard

WI 18101

PERIOD OF PROJECT:

August 1983-Continuing

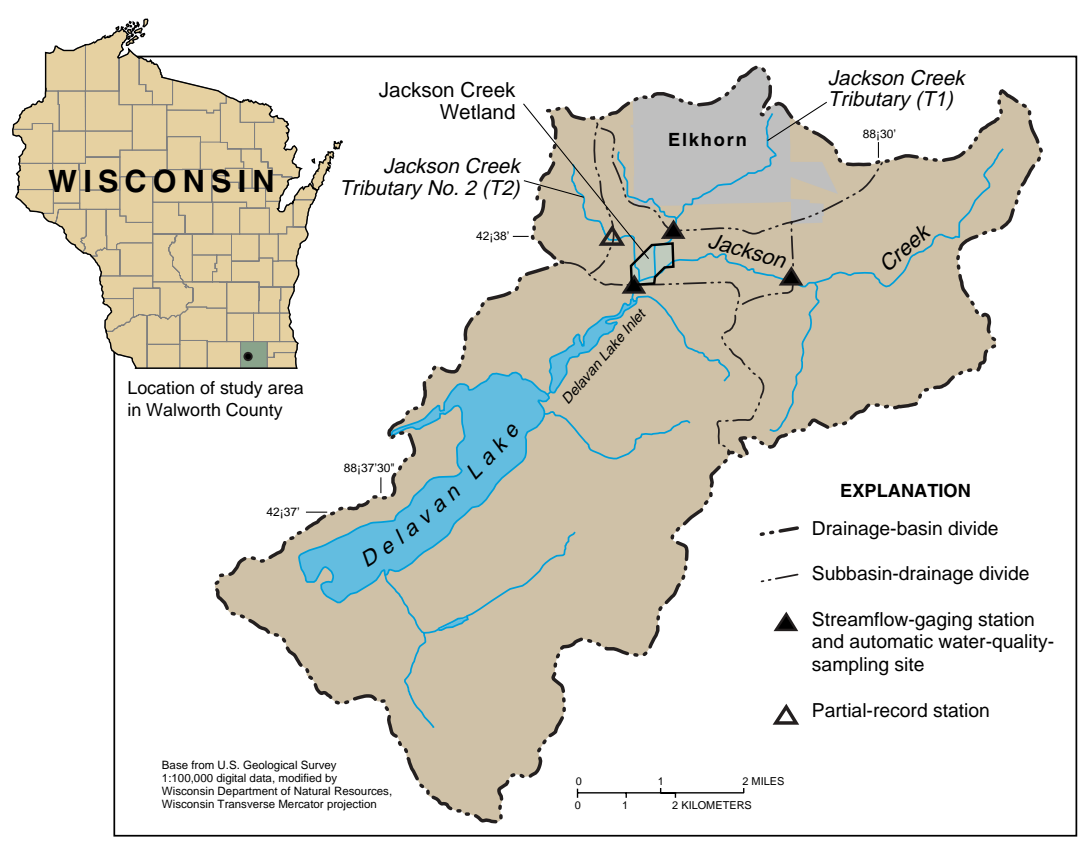

\section{PROBLEM}

Eutrophication of Delavan Lake has accelerated since the 1940s, resulting in a hypereutrophic lake with severe blue-green algae blooms. Extensive rehabilitation efforts were implemented from 1990-1993 to improve the lake's water quality. Monitoring of the lake and nutrient and sediment loads to the lake is continuing to determine the effectiveness of rehabilitation effort and guide future management decisions.

\section{OBJECTIVE}

The objectives of this project are to: (1) quantify the effectiveness of rehabilitation efforts by measuring streamflow and nutrient and suspended sediment loads at Jackson Creek tributary near Elkhorn, Jackson Creek at Mound Road (wetland outlet), Delavan Lake Inlet at Highway 50, and at the lake's outlet, (2) measure water quality, and plankton populations in the lake, and (3) determine the trapping efficiency of the wetland for phosphorus and suspended sediment.

\section{APPROACH}

Nutrients, suspended sediments, and streamflow are monitored at Jackson Creek tributary, the wetland outlet at Mound Road, at Highway 50, and the lake outlet. Nutrient concentrations, dissolved oxygen, water temperature, $\mathrm{pH}$, specific conductance, and planktonic populations are monitored within the lake. The effectiveness of the wetland is estimated by examining changes in the morphometry of the wetland ponds and changes in phosphorus and suspended sediment export at Mound Road.

\section{PROGRESS (July 2001 to June 2002)}

Streamflow was monitored continuously at three inflow sites and at one outflow site. Water samples were collected monthly and during storm runoff events at all stream sites. Water samples were analyzed for nutrients and suspended sediment. The water quality at the center of the lake was monitored. The 2001 water-year data were compiled and published in USGS annual reports, 
"Water Resources Data-Wisconsin, Water Year 2001" and "Water-Quality and Lake-Stage Data for Wisconsin Lakes, Water Year 2001." Lake phosphorus concentrations in 1996-2001 were similar to those prior to rehabilitation that was completed in 1993; however, summer water clarity was greater and chlorophyll $a$ concentrations approached conditions similar to those prior to lake rehabilitation. Additional sediment deposition was measured in the wetland ponds.

\section{PLANS (July 2002 to June 2003)}

The monitoring program will be continued. Data will be compiled for publication.

\section{REPORTS}

Robertson, D.M., Goddard, G.L., Helsel, D.R., and MacKinnon, K.L., 2000, Rehabilitation of Delavan Lake, Wisconsin: Lake and Reservoir Management, v. 20, no. 1, p. 155-176.

Panuska, J.C., and Robertson, D.M., 1999, Estimating phosphorus concentrations following alum treatment using apparent settling velocities: Lakes and Reservoir Management, v. 15, no. 1, p. 28-38.

Robertson, D.M., Elder, J.F., Goddard, G.L., and James, W.F., 1998, Dynamics in phosphorus retention in wetlands upstream of Delavan Lake, Wisconsin: Lakes and Reservoir Management, v. 14, no. 4, p. 466-477.

Elder, J.F., Manion, B.J., and Goddard, G.L., 1997, Mesocosm experiments to assess factors affecting phosphorus retention and release in an extended Wisconsin wetland: USGS Water-Resources Investigations Report 97-4272, $14 \mathrm{p}$.

Goddard, G.L., and Elder, J.F., 1997, Retention of sediments and nutrients in Jackson Creek Wetland near Delavan Lake, Wisconsin, 1993-95, USGS Water-Resources Investigations Report 97-4014, $22 \mathrm{p}$.

Elder, J.F., and Goddard, G.L., 1996, Sediment and nutrient trapping efficiency of a constructed wetland near Delavan Lake, Wisconsin, 1993-1995: U.S. Geological Survey Fact Sheet 232-96.

Robertson, D.M., Field, S.J, Elder, J.F., Goddard, G.L., and James, W.F., 1996, Phosphorus dynamics of Delavan Lake inlet in southeastern Wisconsin: U.S. Geological Survey Water-Resources Investigations Report 96-4160, $18 \mathrm{p}$.

Field, S.J., and Duerk, M.D., 1988, Hydrology and water quality of Delavan Lake in southeastern Wisconsin: U.S. Geological Survey Water-Resources Investigations Report 87-4168, $61 \mathrm{p}$.

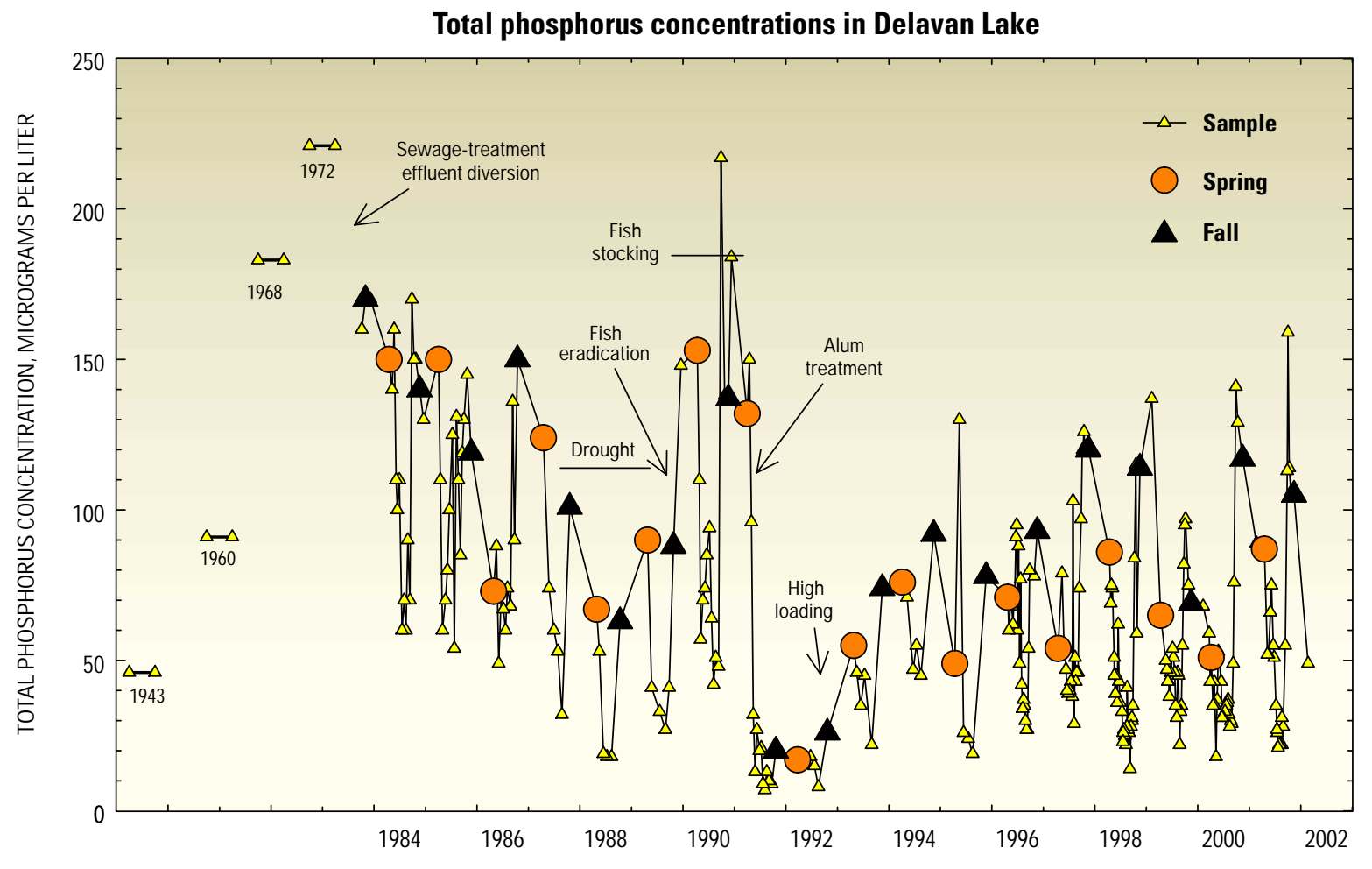

Surface phosphorus concentrations in Delavan Lake. Important remedial efforts and climatic events are identified. 


\section{MERCURY TEAM}

\section{Mission}

The mission of the Wisconsin District Mercury Research Laboratory (WDMRL) is to provide a better overall understanding of mercury contamination of aquatic ecosystems by conducting scientific studies and providing expert assistance to the USGS and other state and Federal agencies. Assistance is provided through consultation, drafting and reviewing proposals, field sampling, sample analysis, interpreting data, and drafting reports. We strive to provide the best possible data and service by remaining on the cutting edge of mercury research, and maintaining a state-of-the-art mercury analysis laboratory

\section{Team Members}

David P. Krabbenhoft, Research Hydrologist/ Geochemistry

Mark L. Olson, Biologist

John F. DeWild, Hydrologic Technician

Shane D. Olund, Chemist

Paul D. Sternhagen, Hydrologic Technician

Todd M. Rudolph, Contract

M.T. Tate, Contract

\section{PROJECTS}

Florida Everglades mercury cycling, WI 19700 90 National mercury project, WI 22900.

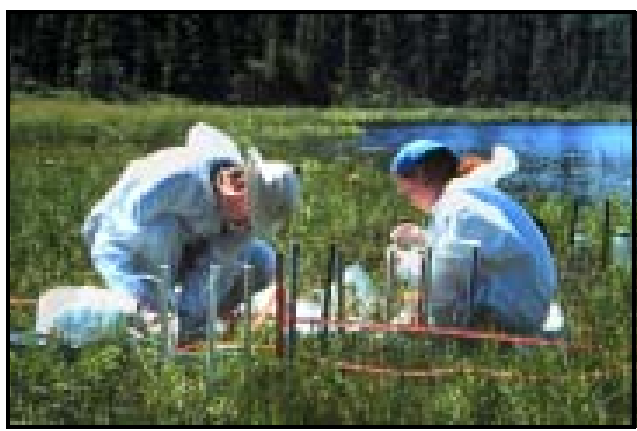

Sampling pore waters in a wetland at the Experimental Lakes Area, Ontario Canada.

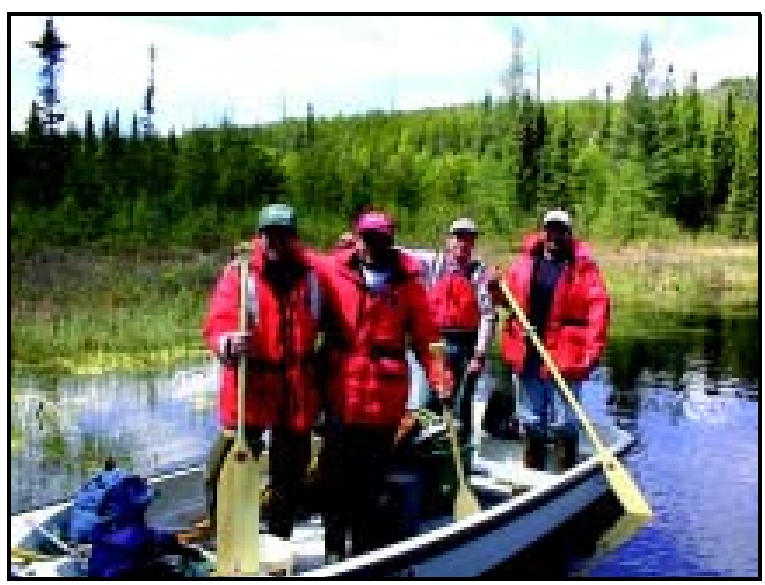

USGS Field Team at the Mercury Experiment to Assess Atmospheric Loading in Canada at the U.S. (METAALICUS) project site. 


\title{
FLORIDA EVERGLADES MERCURY CYCLING
}

\section{COOPERATOR:}

\author{
U.S. Geological Survey, \\ Reston, Virginia
}

\section{PROJECT CHIEF:}

David P. Krabbenhoft

\section{LOCATION:}

Florida Everglades

\section{PROJECT NUMBER:}

WI 19700

\section{PERIOD OF PROJECT:}

January 1995-Continuing
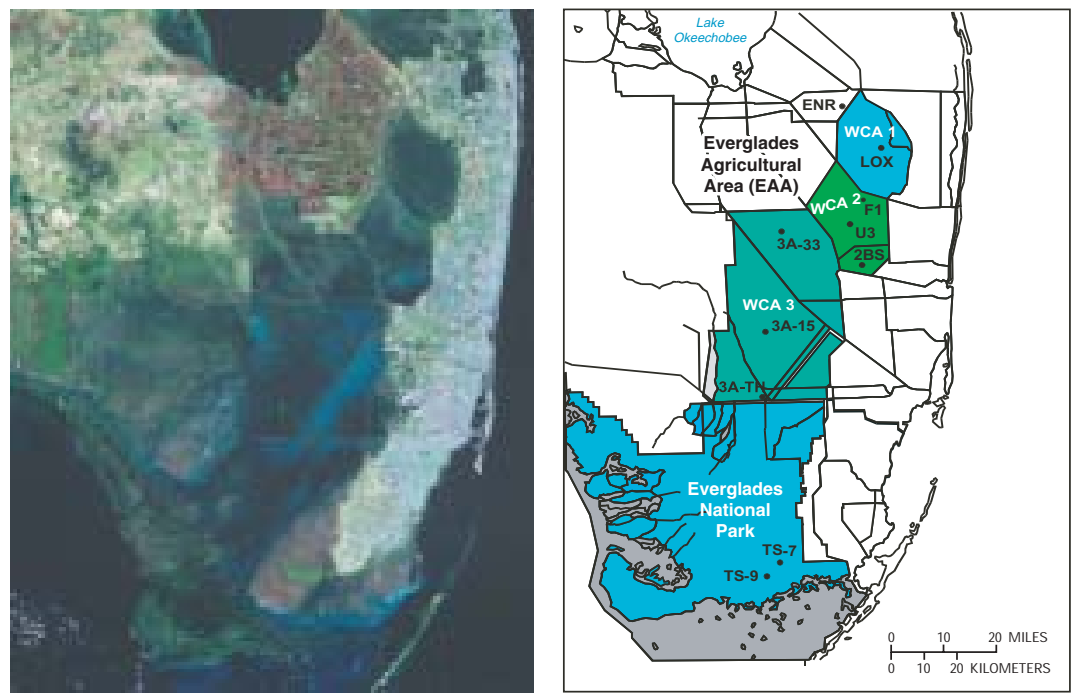

Satellite and field location maps of the Everglades Mercury Research site.

\section{PROBLEM}

Mercury contamination is one of the largest potential health risks to aquatic organisms, predatory animals, and humans. This great concern is the result of two observations: (1) mercury biomagnifies in the food chain to toxic concentrations even though it is found at very low aqueous concentrations, and (2) the principal source to most areas is atmospheric deposition. Thus, almost any aquatic ecosystem with a food chain is potentially susceptible to mercury contamination.

\section{OBJECTIVE}

The overall objective of this project is to provide a better understanding of the mercury contamination problem in the Florida Everglades and other aquatic ecosystems. Specific processes will be investigated, including particle and dissolved transport, volatilization, methylation, and interactions with dissolved organic carbon.

\section{APPROACH}

Mercury contamination of the Florida Everglades has been recognized as a serious problem for over a decade, yet solutions to the problem have remained elusive. Research conducted by the Wisconsin District Mercury Research Laboratory from 1995 to 2000 on the factors leading to high levels of mercury bioaccumulation revealed that in addition to mercury inputs, sulfate, phosphate, and organic carbon loading from upstream point sources, as well as water-level management, all likely contribute to the problem. To aid in the decisionmaking process for the Consolidated Everglades Restoration Program (CERP), which is an interagency program charged with developing the restoration plan for the Everglades, we have taken a new direction in our research to directly evaluate the relative importance of each of the co-factors. Briefly, we have installed 75 wetland enclosures at five sites in the Everglades, and within them we are performing chemical addition studies using stable isotopes of mercury, sulfate, phosphate and organic carbon to quantify the dose response of 
each to the formation of methylmercury and bioaccumulation in the food web. Following each amendment, sediment, surface water, pore water, plant, and fish samples are collected at several time intervals for periods up to six months. With this type of information, we will be able to provide a much clearer quantitative context of the relative importance of each of the contributing factors to the mercury problem, and agencies responsible for direction. Everglades restoration efforts can more reliably make decisions on what preventive actions can made with regard to mercury toxicity in the Everglades.

\section{PROGRESS (July 2001 to June 2002)}

In November 2001, we initiated for the first time a full scale experiment of our dosing studies. The experiment was run through February 2002, and included three complete sampling periods during course of the study. Currently, we are analyzing the large number of samples that were generated from this experiment. Samples are analyzed on the new Inductively Coupled Plasma Mass Spectrometer (ICPMS) that is operated by the Mercury Studies Team, in the Wisconsin District Office. Early results suggest that there were significant responses to each chemical amendment, including some responses that were not anticipated. At the conclusion of the dosing study, a sediment-core incubation study was initiated to test the response of drying and rewetting cores to the production of methylmercury, which we observed in the natural environment after dry periods. This experiment is scheduled to continue through the end of May 2002.

\section{PLANS (July 2002 to June 2003)}

Plans for this time period call for the analysis of all the samples collected during the recent study, and the samples generated from the ongoing core-incubation experiment. Once all the sample results are available, we will prepare at least three reports on our results in the format of scientific journal papers. The interpretations and final conclusions of these experiments may be used to guide future tests to further evaluate the Everglades mercury problem and what can be done to mitigate its impact.

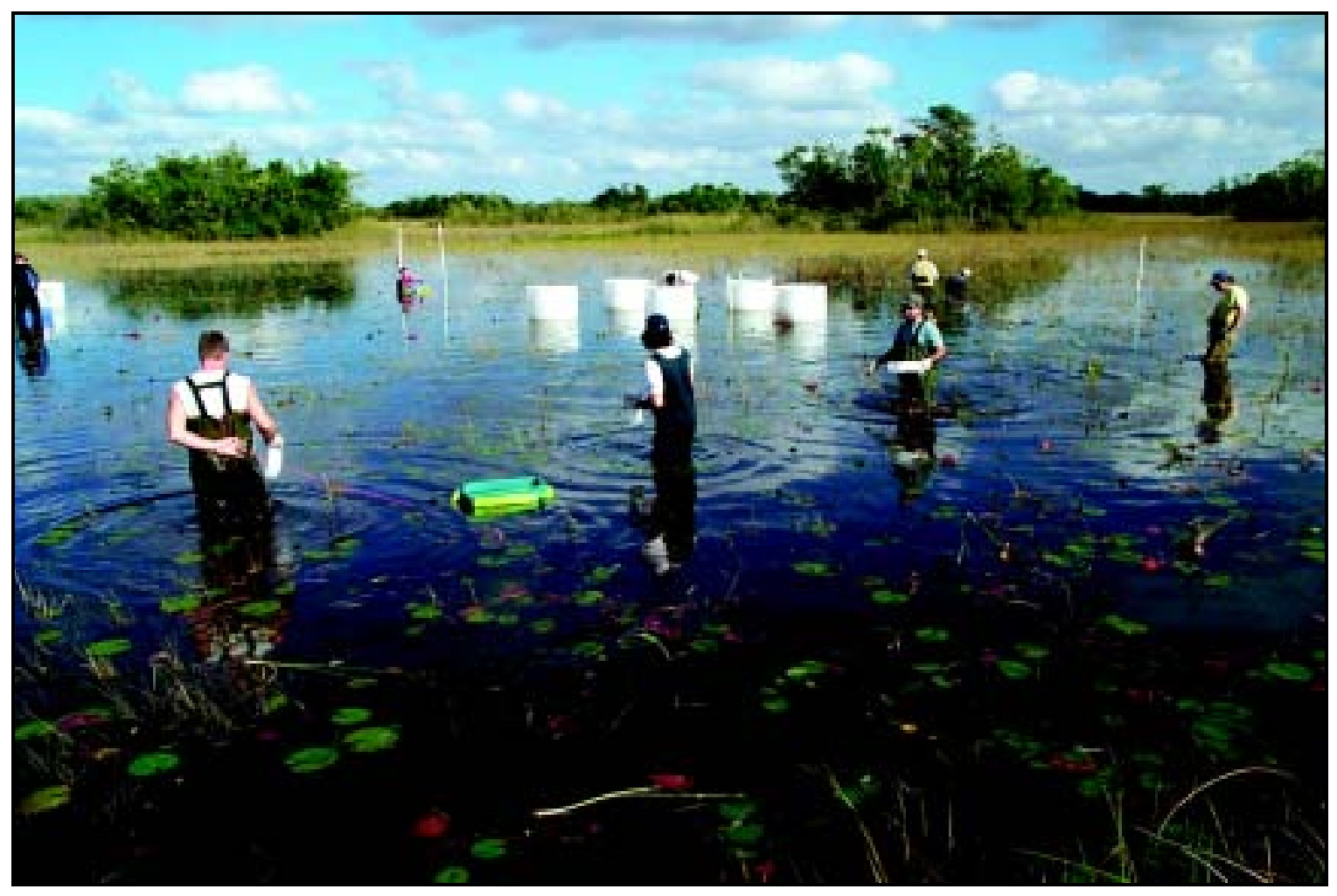

USGS field crews sampling in the Everglades. 


\section{NATIONAL MERCURY PROJECT}

\section{COOPERATOR:}

Toxic Substances Hydrology Program

PROJECT CHIEF:

David P. Krabbenhoft

\section{LOCATION:}

Nationwide

PROJECT NUMBER:

WI 22900

PERIOD OF PROJECT:

July 2001 to June 2006

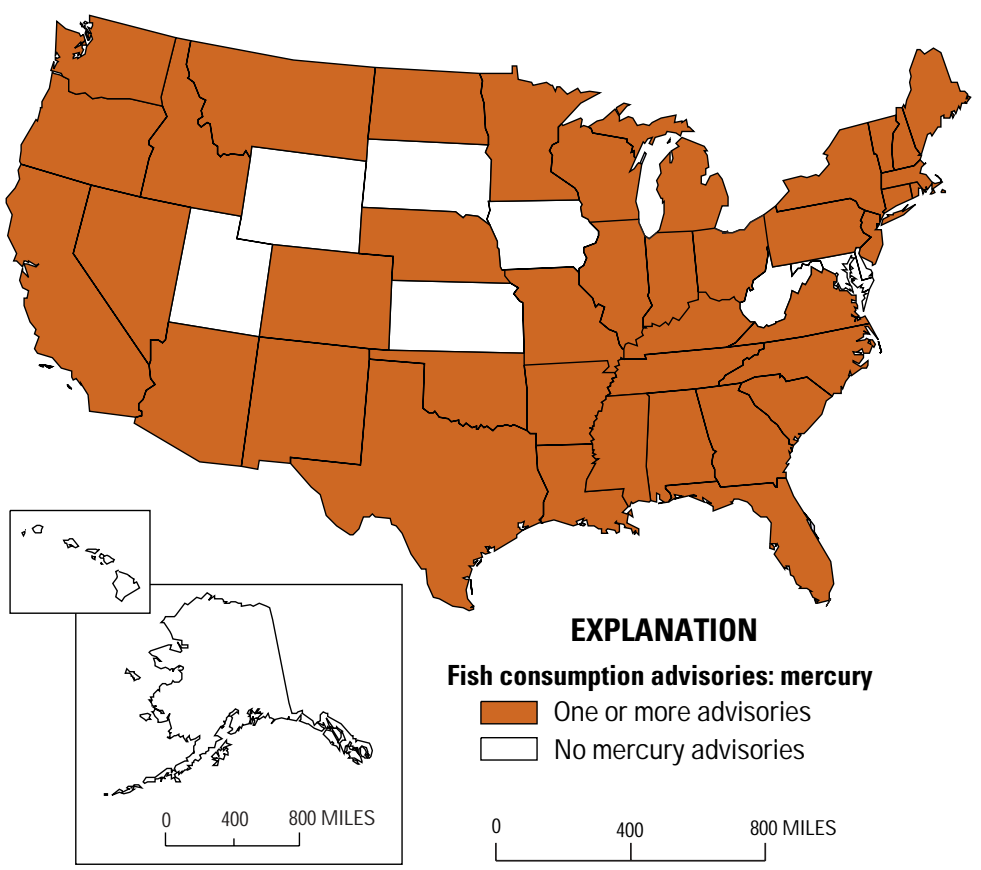

\section{PROBLEM}

Mercury $(\mathrm{Hg})$, which is distributed primarily by atmospheric pathways, is a global pollutant that we are still working toward trying to understand the magnitude, controlling factors, and its potential effects on ecosystems and humans. Consumption advisories for $\mathrm{Hg}$-contaminated fish are currently in place for 41 United States. In some states, including Wisconsin, the problem is so acute that statewide advisories for the consumption of all sport fish have been issued. Despite increased awareness of the problem, it remains unclear whether current $\mathrm{Hg}$ releases, or ecosystem sensitivity to $\mathrm{Hg}$ loading controls the distribution of problem spots in the United States, and what positive outcomes might be realized from proposed $\mathrm{Hg}$ emissions reductions by the U.S. Environmental Protection Agency.

\section{OBJECTIVE}

The overall goals of this project are to seek to clarify the broader mercury problem from a scientific and resource management perspective, and provide information that will aid decision makers on what should be done to improve environmental $\mathrm{Hg}$ conditions. Specific tasks we are undertaking to achieve these goals are to: (1) fill critical data gaps that currently hinder a more complete understanding of mercury contamination across the United States, and (2) conduct research that will allow for a better quantitative understanding relating mercury releases to the environment and contamination levels in aquatic food webs.

\section{APPROACH}

To achieve these goals, the Wisconsin District Mercury Research Team is conducting a variety of field-oriented studies. First, in the summer of 2002 we are continuing our collaboration with the NAWQA program to collect fish, water and sediment samples from across the United States in a variety of watershed types. This synoptic type sampling will be followed by more intense sampling efforts a few of the watersheds where the goal will be to provide a detailed understanding of the processes that control mercury bioaccumulation in food webs. In addition, the Mercury Research Team is involved in two "mercury-loading" studies in the Ever- 
glades of Florida and the Experimental Lakes Area (ELA) of Ontario, Canada, whereby the overall goal is to establish what the mercury dose to bioaccumulation response is for natural systems using traceable amounts of mercury stable isotopes. Previously, research of this kind has been conducted in laboratories or controlled environments where the natural response was not adequately represented. For the study site in Canada, we are dosing an entire watershed with three different stable isotopes of mercury $\left({ }^{198} \mathrm{Hg},{ }^{200} \mathrm{Hg}\right.$, and $\left.{ }^{202} \mathrm{Hg}\right)$, which are being added to the wetland, upland forests, and lake, respectively. By applying different stable isotopes to the three major components of the watershed, we will be able to track where the mercury comes from, and at what time scales, that accumulates in fish.

\section{PROGRESS (July 2001 to June 2002)}

In the summer of 1998 the Wisconsin District Mercury Research Laboratory and the Toxic Substances Hydrology and National Water-Quality Assessment (NAWQA) Programs conducted a national sampling of fish, sediment and water from 106 sites that were located in 21 NAWQA study basins. This effort was the first of its kind, and provided many insights into the level of mercury contamination across the United States that had never been documented. In the spring of 2002, a similar effort will be conducted at about 140 sites located in 14 study basins across the United States.
We are now into our second year of dosing stable isotope studies in the Everglades, and one year of full isotope application to the whole watershed study in Canada. After each dosing, intense sampling is conducted to follow the pathways for the isotopes through the ecosystem, and the transformation sites and rates for methylmercury production. Samples are analyzed at the Wisconsin District Mercury Research Laboratory using the inductively coupled, quadra pole mass spectrometer that is capable of distinguishing among the isotopes of mercury at very low levels of addition.

\section{PLANS (July 2002 to July 2003)}

Plans for this time period call for continued sampling efforts at the 14 NAWQA study basins, but in a much more detailed manner to evaluate why some basins exhibit high levels of mercury bioaccumulation and others low. This work will be conducted collaboratively with the NAWQA program, National Research Program, and scientists from the Biological Resources Discipline. Analytical results from samples collected in 2002 will be used to identify the sites of more detailed examination. Once all the sample results are available, we will prepare at least three reports on our results in the format of scientific journal papers. The interpretations and final conclusions of these experiments may be used to guide future tests to further evaluate where and what kind of additional studies need to be conducted.

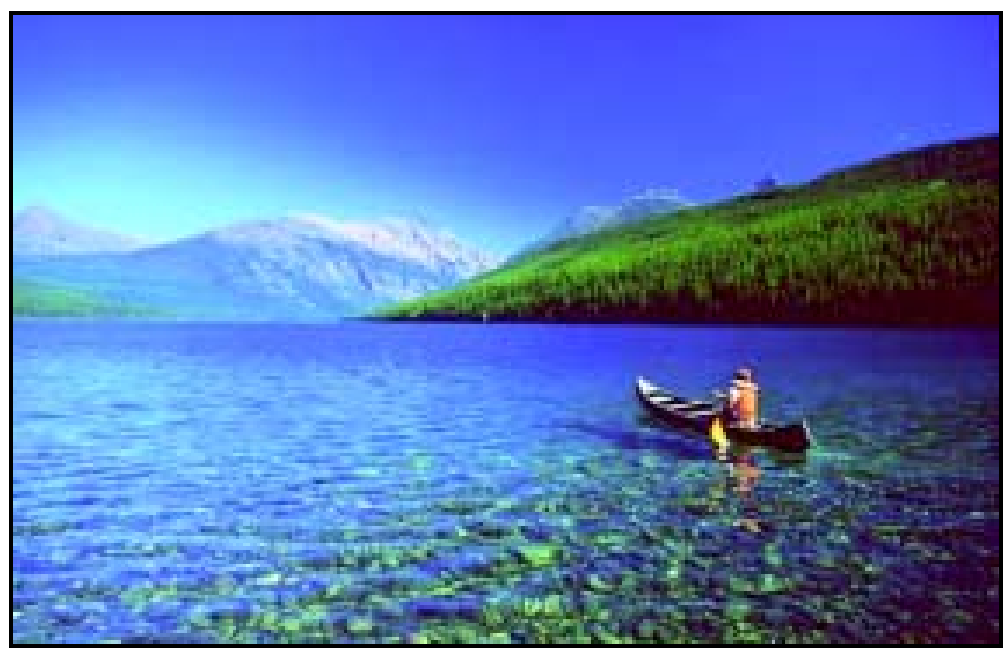

Sampling at Mokowanis Lake, Glacier National Park, during the High Elevation Lakes Study of 1999. 



\section{MULTIDISCIPLINARY WATER-QUALITY ASSESSMENT}

\section{Mission}

The Multidisciplinary Water-Quality Assessment Team conducts studies of the physical, chemical, and biological components of hydrologic systems. Investigations focus on water-quality issues, utilize new technologies and techniques, and are conducted over a wide range of spatial and temporal scales. The goal of the team is to understand the interactions among components of hydrologic systems and their relations to water quality in order to enhance the management of water resources.

\section{Team Members}

Morgan A. Schneider, Hydrologist

Charlie A. Peters, Hydrologist

Dale M. Robertson, Research Hydrologist

Faith A. Fitzpatrick, Research Hydrologist

Barbara C. Scudder, Hydrologist

Daniel J. Sullivan, Hydrologist

Jana S. Stewart, Geographer

Kevin D. Richards, Physical Scientist

Brett M. Esser, Hydrologic Technician

Judith C. Thomas, Hydrologist

Krista A. Stensvold, Hydrologist

Matthew W. Diebel, Hydrologic Technician

Elisa A. Graffy, Environmental Policy Specialist

Sharon A. Fitzgerald, Research Hydrologist

Michelle A. Lutz, Physical Scientist

Robert A. Rose, Geographer
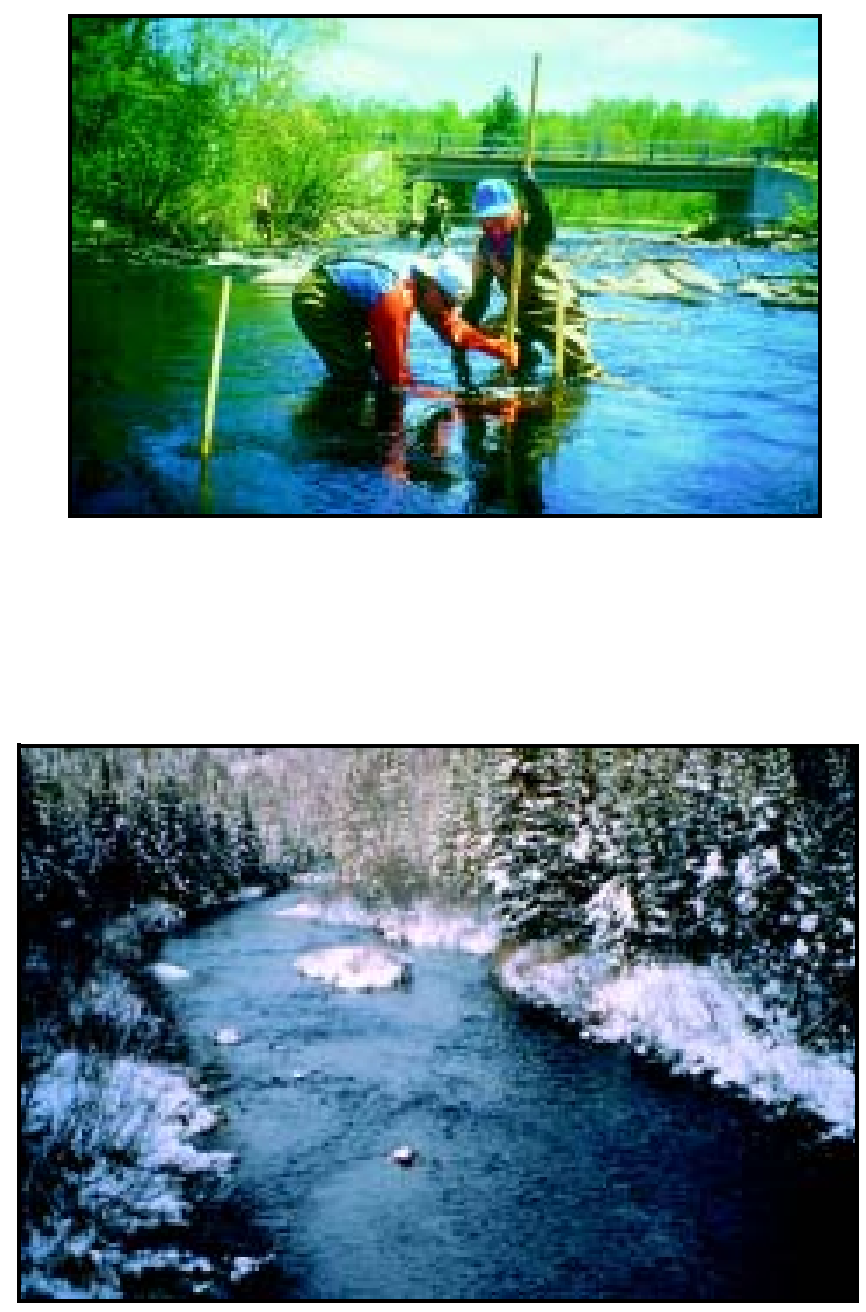


\section{PROJECTS}

Interagency Methods and Data Comparability Board (MDCB), WI 00303 ................................................................ 97

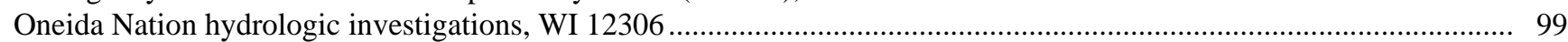

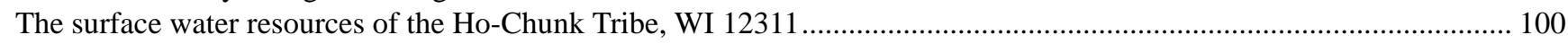

Western Lake Michigan drainages National Water-Quality Assessment (NAWQA), WI 17400 ...................................... 101

Upper Illinois River Basin National Water-Quality Assessment (NAWQA), WI 17402 .................................................. 104

National Water-Quality Assessment (NAWQA) special, WI 17403 .......................................................................... 106

Demonstration of submerged vanes, Fish Creek, WI 19300 ...................................................................................... 107

Hydrologic literature search and digital data compilation of Camp Wismer and proposed hydrologic investigation

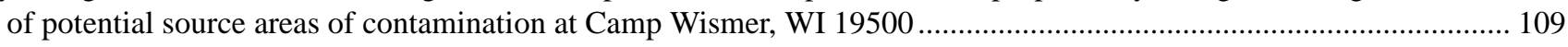

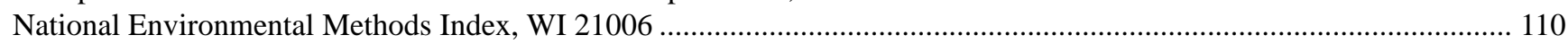

Neopit Mill pond sedimentation and sediment chemistry study, WI 21101_............................................................. 112

St. Croix National Scenic Riverway—nutrient and sediment loading and long-term water-quality monitoring,

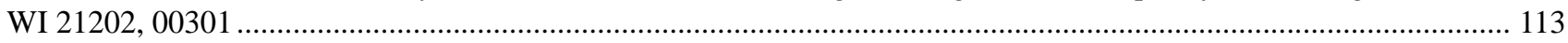

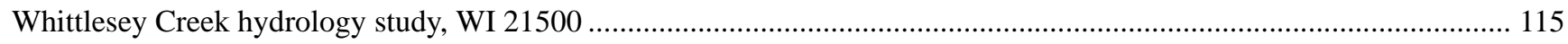

Historical ecosystem reconstruction and potential identification of effects of past ecosystem perturbations in

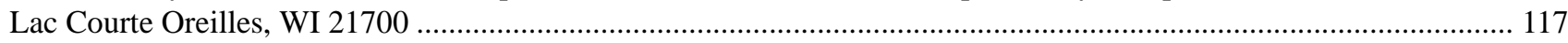

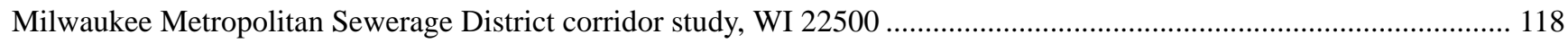

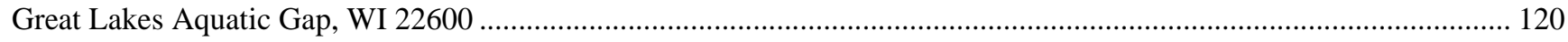

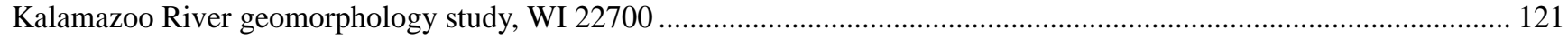

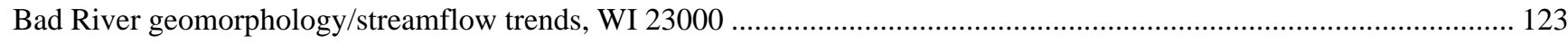




\section{INTERAGENCY METHODS AND DATA COMPARABILITY BOARD (MDCB)}

\section{COOPERATOR:}

U.S. Geological Survey

\section{PROJECT CHIEF:}

Charles A. Peters

\section{LOCATION:}

Comprised of individuals from throughout the United States

\section{PROJECT NUMBER:}

WI 00303

\section{PERIOD OF PROJECT:}

April 1998 to April 2003

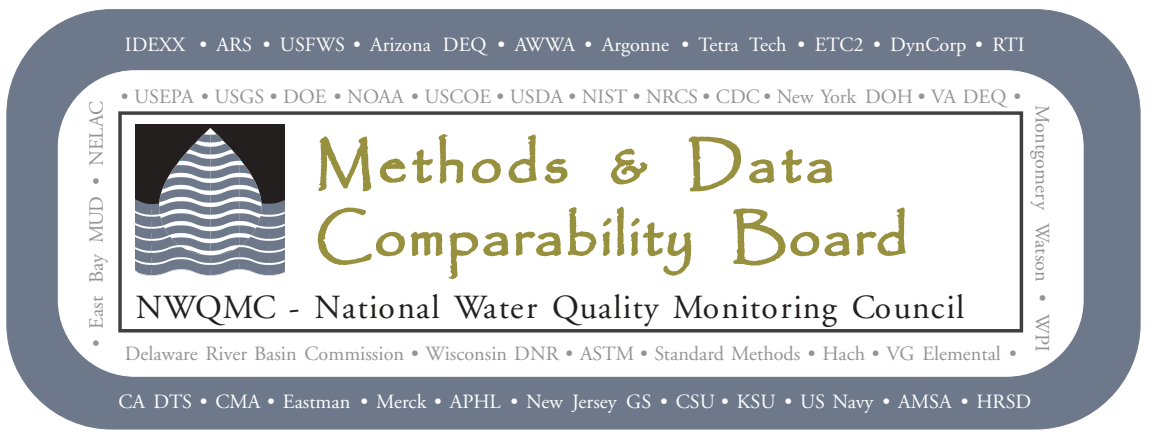

\section{PROBLEM}

Significant resources are spent to monitor water quality in the United States. The methods used to collect water samples and to analyze the samples collected vary between the collecting authority. The data obtained using the various methods may not be comparable and therefore monitoring entities may collect duplicate data.

\section{OBJECTIVE}

A nationwide partnership of water-monitoring authorities from Federal and State agencies, tribes, municipalities, business and industry, academia, and others with expertise in environmental monitoring has been assembled to coordinate and provide guidance for implementation of a voluntary, integrated, nationwide monitoring strategy that will provide comparable data.

\section{APPROACH}

The MDCB holds quarterly meetings to discuss the progress and plans of work groups formed to develop consensus positions regarding issues related to sampling and analytical approaches. The eight work groups (Performance Based Systems, National Environmental Methods Index, Laboratory Accreditation and Field Certification, Biological Methods, Nutrient Methods, Water Quality Data Elements, New Technologies, and Publicity and Outreach) establish work plans and meet via conference calls and at the quarterly MDCB meetings to accomplish work plan objectives.

\section{PROGRESS (July 2001 to June 2002)}

The USGS Methods Board co-chair is responsible for maintaining a public and internal board website, developing work plans, organizing meetings and conference calls, preparing meeting minutes, assisting with the preparation of position papers and pilot studies, preparing outreach products, and providing guidance for and participating in other MDCB activities. The cochair also participates as a member of the National Water Quality Monitoring Council (NWQMC), as a member of the NWQMC steering committee, and as a co-chair for the National Monitoring Conferences. 


\section{PLANS (July 2002 to April 2003)}

The co-chair will continue to maintain a public website, develop work plans, organize meetings and conference calls, prepare meeting minutes, assist with the preparation of position papers and pilot studies, prepare outreach products, and provide guidance for and participate in other MDCB activities. The co-chair also participates as a member of the National Water Quality Monitoring Council (NWQMC), and as a member of the NWQMC steering committee.

\section{REPORTS}

MDCB, 1998, National Methods and Data Comparability Board: Collaboration and Comparability, Fact Sheet.

Eaton, A. and J. Diamond, 1999, Reservoir Dogs and Performance Based Systems, Environmental Testing and Analysis, May/June1999.

Brass, H., Spooner, C., Klein, J.M., Shockey, M., 1999, Objectives and Activities of the National Water Quality Monitoring Council, International Conference of the Israel Society for Ecology and Environmental Quality Sciences, Jerusalem, Israel, June, 1999.

Diamond, J., Stribling, S., Yoder, C., 1998, Determining the Comparability of Bio-assessment Methods and Their Results, NWQMC National Monitoring Conference 1998, Reno, NV, July, 1998.

Strong, A., 1998, Performance Based Methods Systems, NWQMC National Monitoring Conference 1998, Reno, NV, July, 1998.

Eaton, A. 1999, Performance Based Systems (PBMS)- the Methods and Data Comparability Board Approach, 15th Annual WTQA Conference, Washington, DC July, 1999.

Brass, H., 1999, The Methods and Data Comparability Board: Collaboration and Comparability, American
Water Works Association - Water Quality Technology Conference., Tampa, FL, November, 1999.

Eaton, A., Diamond, J., Annis, C., Strong, A., McChesney, D., Brass, H., Shockey, M., 1999, Reservoir Dogs and Performance Based Systems for the Analysis of Environmental Contaminants, American Water Works Association - Water Quality Technology Conference, Tampa, FL, November 1999.

MDCB, 2000, Why is a National Environmental Methods Index Needed?, Fact Sheet.

Parr, J., 2000, Determining and Documenting the Suitability of Analytical Procedures Used for Analysis of Environmental Samples, NWQMC National Monitoring Conference 2000, Austin, TX, April 2000.

Peters, C., Brass, H., Diamond, J., 2001, United States Water Quality Methods and Data Comparability Board: Creating a Framework for Collaboration and Comparability, Monitoring Tailor Made III, Nunspeet, Netherlands, September, 2000.

Brass, H., Ardourel, H., Diamond, J., Eaton, A., Keith, L., Peters, C., 2000, Activities of the Interagency Methods and Data Comparability Board, American Water Works Association - Water Quality Technology Conference, Salt Lake City, Utah, November 2000.

Diamond, J., Eaton, A., Annis, C., Brass, H., Keith, L., Strong, A., McChesney, D., Shockey, M., 2001, Towards a Definition of Performance-Based Laboratory Methods, National Water Quality Monitoring Council Technical Report 01-02.

Keith, L., Sullivan, D., Boiani, J., Brass, H., Peters, C., 2001, The National Environmental Methods Index as a Tool to Achieve Methods Comparability, American Water Works Association-Water Quality Technology Conference, Nashville, TN, November, 2001.

MDCB, 2001, National Methods and data Comparability Board: Collaboration and Comparability, Fact Sheet. 


\section{ONEIDA NATION HYDROLOGIC INVESTIGATIONS}

\section{COOPERATOR:}

Oneida Nation of Wisconsin

PROJECT CHIEF:

Kevin D. Richards

\section{LOCATION:}

Oneida Indian Reservation

PROJECT NUMBER:

WI 12306

\section{PERIOD OF PROJECT:}

August 1997 to September 2003

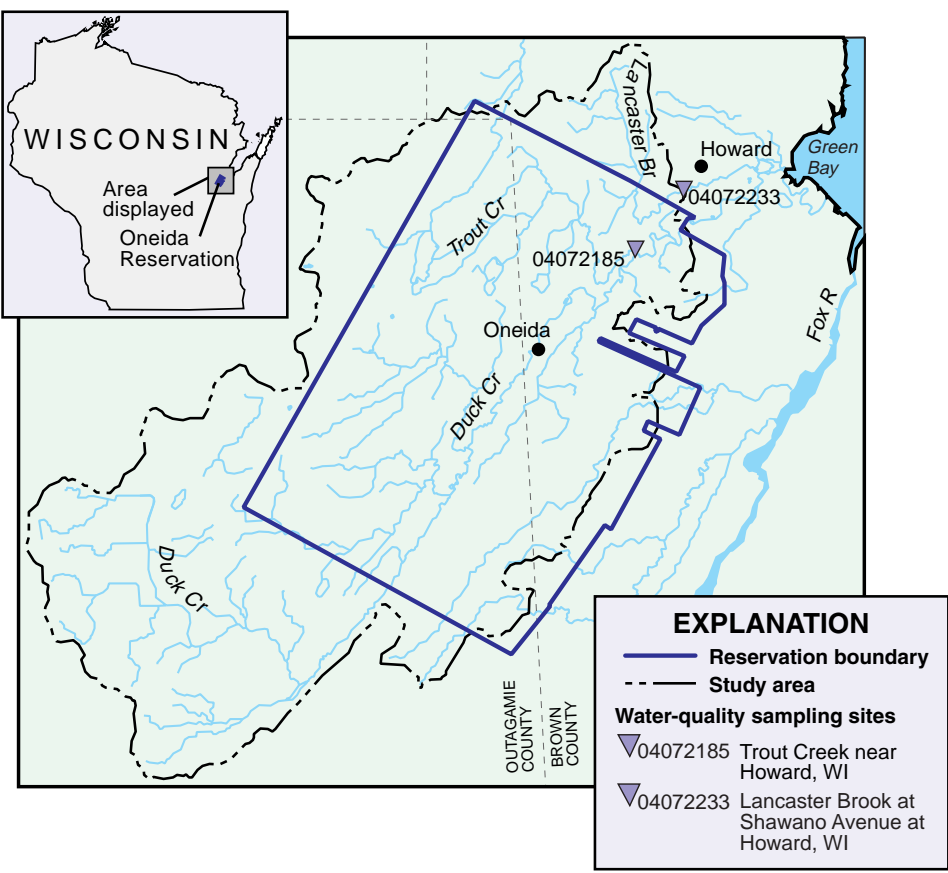

\section{PROBLEM}

The Oneida Nation in Wisconsin has developed a seven-generation plan for their reservation that includes instituting land-use practices that will allow the surfacewater system draining the reservation the opportunity to revert to its pre-colonial condition. The Oneida Nation needs continuing information regarding water-quality conditions entering and within their Nation's boundaries. The information is needed to determine trends in water quality and provide data to assess the Tribe's water resources.

\section{OBJECTIVE}

The objective is to collect long-term data at two sites to perform trend analysis for pesticides, nutrients and suspended sediment.

\section{APPROACH}

Sampling will be conducted at two sites to determine concentrations of nutrients, pesticides, and suspended sediment. Field parameters will also be collected and sampling will take place on a fixed interval. The National Water Quality Lab will do the analysis of the water samples. National Water-Quality Assess- ment protocols will be followed in the collection and handling of the water-column samples. A staff person from the Oneida Nation Environmental Section will work with a USGS staff person in the collection of data.

\section{PROGRESS (July 2001 to June 2002)}

Samples were collected at two sites monthly plus four events. Samples were analyzed for pesticides, nutrients and suspended-sediment concentrations. Data collected in 2001 were published in the report, "Water Resources Data-Wisconsin, Water Year 2001."

\section{PLANS (July 2002 to June 2003)}

Data from samples collected from October 1, 2002 through September 30, 2003, will be published in the report, "Water Resources Data-Wisconsin, Water Year 2001." Water-quality sampling will be conducted at two sites and continue indefinitely.

\section{REPORTS}

Schmidt, M.A., Richards, K.D. and Scudder, B.C., 2000, Surface-water quality, Oneida Reservation and vicinity, Wisconsin, 1997-98, U.S. Geological Survey WaterResources Investigations Report 00-4179, 30 p. 


\section{THE SURFACE WATER RESOURCES OF THE HO-CHUNK TRIBE}

\section{COOPERATOR:}

Ho-Chunk Nation of Wisconsin

PROJECT CHIEF:

Daniel J. Sullivan

\section{LOCATION:}

Jackson, Sauk, Monroe, Juneau, Wood, and Shawano Counties

PROJECT NUMBER:

WI 12311

PERIOD OF PROJECT:

September 2000-Continuing

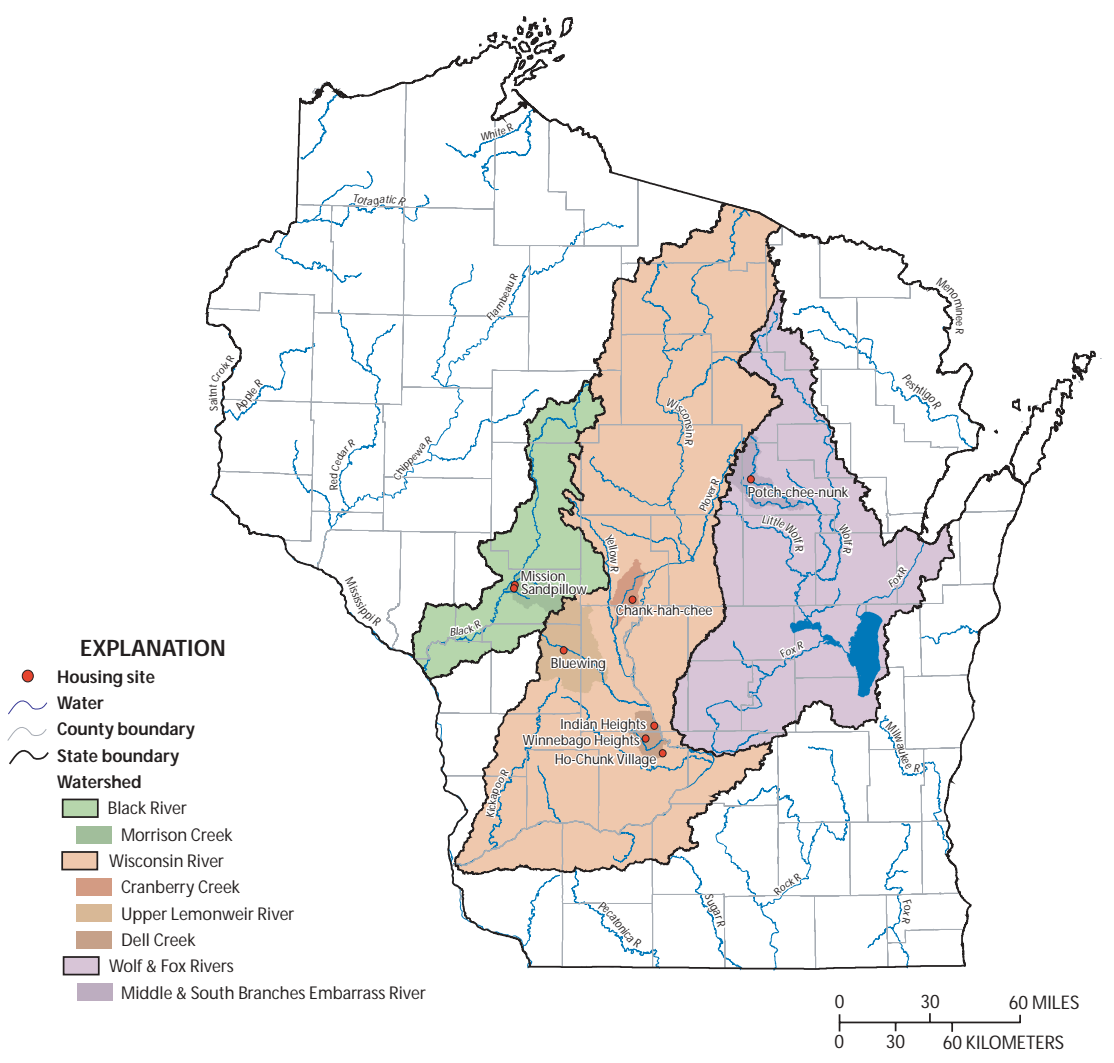

\section{PROBLEM}

The Ho-Chunk Nation is concerned about the condition of streams and rivers on and around their residential lands because tribal members use these waters for food and recreation. Information regarding these waters is scarce and no summary of information is available.

\section{OBJECTIVE}

The objective is to provide the Nation with information about their surface water resources that will allow them to: (1) make decisions about using these waters for food and recreation, and (2) initiate a monitoring program for important waters.

\section{APPROACH}

Information on physical, chemical and biological characteristics of streams within a one-mile radius of Ho-Chunk residential lands will be collected through a literature and database search and summarized in a retrospective report. This summary will provide a basis for designing a sampling plan that will be carried out on selected streams to augment historical information.

\section{PROGRESS (July 2001 to June 2002)}

Preparation of the retrospective report continues. A sampling plan for 2002 is complete.

\section{PLANS (July 2002 to June 2003)}

The retrospective report is planned as a Water Resources Investigations report. Water quality and fish and invertebrate communities will be sampled during the period of May-September, 2002. A report, summarizing and analyzing the results of these surveys, is planned for FY2003. 


\section{WESTERN LAKE MICHIGAN DRAINAGES NATIONAL WATER-QUALITY ASSESSMENT (NAWQA)}

\section{COOPERATOR: \\ U.S. Geological Survey, Reston, Virginia \\ LOCATIONS:}

Upper peninsula of Michigan from the Menominee River basin in the west to the Fishdam River basin in the east; and the eastern portion of Wisconsin to include the Menominee, Oconto, Peshtigo, Fox-Wolf River basins discharging to Green Bay, and in Wisconsin that directly drain into Lake Michigan from the west which include the Manitowoc, Sheboygan, Milwaukee, Root, and Pike River basins.

\section{PROJECT NUMBER:}

WI 17400

\section{PROJECT CHIEF:}

Charles A. Peters

\section{PERIOD OF PROJECT:}

December 1990-Continuing

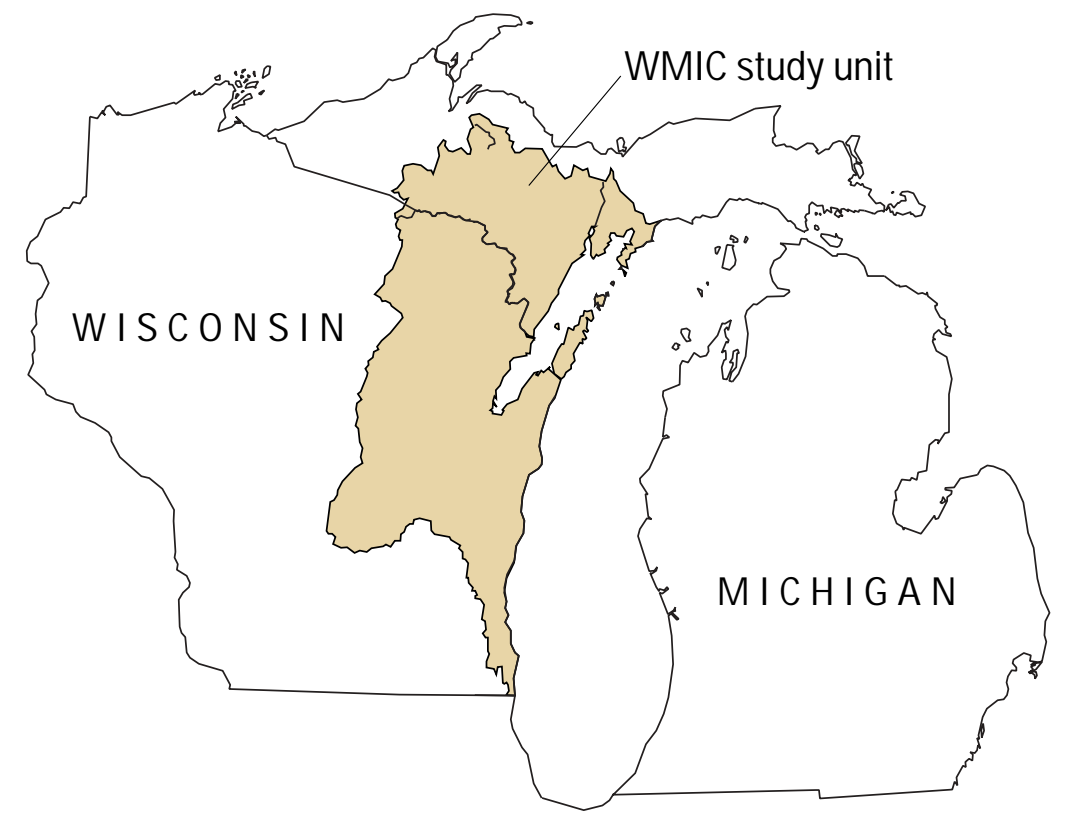

determine the presence or absence of any trends in the water quality, and provide an understanding of the link between natural and anthropogenic factors and observed water quality.

\section{APPROACH}

Western lake Michigan Drainages study unit investigations will be conducted in 10-year cycles. Cycle 1 took place between 1991 and 2000 and consisted of a retrospective analyses of existing water quality (1991-1993), high intensity phase data collection (1993-1995), data analyses and report writing (1995-1997), and low-intensity phase data collection (1996-2000). Cycle 2 began with a planning and retrospective data analyses phase (2000-2001) and will be

in the Western Lake Michigan Drainages (WMIC), 
followed by high-intensity phase data collection (2001-2003), topical study data collection (2002-2004), data analyses and report writing (2003-2006), and low intensity phase data collection (2004-2010).

These types of studies will be conducted as part of the Western Lake Michigan Drainages study unit investigation: (1) occurrence and distribution assessments;

(2) trends assessments; and (3) topical studies.

The surface water occurrence and distribution and trends assessment networks were developed by identifying relatively homogeneous areas of specific land use and environmental characteristics. Sampling sites were chosen to assess watersheds representing a single relatively homogeneous unit (RHU) or watersheds defined by several RHUs. Sites sampling a single RHU were called indicator sites and those sampling several RHUs were termed integrator sites.

The ground water sampling networks were designed to assess the primarily used aquifers in the study unit: the Cambrian-Ordivician Sandstone and the glacial outwash aquifer systems, and also to assess the effect of various land uses on shallow ground water.

\section{PROGRESS CYCLE 1 (1991-2000)}

Eleven basic-fixed sites (BFS) were sampled during the cycle 1 high-intensity sampling phase (HIP), 8 indicator sites and 3 integrator sites. The sites were sampled monthly and augmented with seasonal storm sampling for major ions, nutrients, organic contaminants, trace elements, suspended sediments, and pesticides during the HIP. Several agricultural and urban land use indicator sites were also sampled more intensively for pesticides during the growing season. The eleven BFS were also assessed for habitat and sampled for fish, macro-invertibrate, and algae annually during the HIP.

The ground water occurrence and distribution assessment networks were developed around major aquifers in the study unit. During cycle 1, twenty-nine wells in the Cambrian-Ordivician aquifer system were sampled for major ions, nutrients, VOCs, trace elements, radon, tritium, DOC, and pesticides. The shallow ground water land use networks studied the effect of surficial deposits (clayey or sandy) in agricultural areas on water quality.

Streambed sediments and tissue from aquatic biota were sampled at each of the fixed sites and about twenty-five additional sites throughout the basin during cycle 1 . These samples were analyzed for trace metals, pesticides, and organic compounds.

Special studies during cycle 1 included: a comparison of shallow ground water chemistry in agricultural areas with varying permeability; ground water flow path investigation of agricultural chemical transport; an assessment of biological communities in benchmark streams in agricultural areas; assessments of high- and low-flow chemical conditions; a study to determine the representativeness of the BFS; an investigation of ground water surface water interactions at the end of a flow path; and two studies comparing results obtained using a variety of chemical and biological sampling methods.

Low-intensity phase samples were collected monthly at 3 of the BFS for major ions, nutrients, organic contaminants, trace elements, suspended sediments, and pesticides.

Forty-seven reports were prepared to describe the results of the cycle one investigations.

\section{PLANS CYCLE 2 (2001-2010)}

During cycle 2, trends sampling will include sampling at 4 of the BFS, now termed trends sites, for the same list of constituents and at a similar frequency as analyzed for during cycle 1 . The Cambrian-Ordivician aquifer wells and the highly permeable shallow groundwater wells in agricultural areas will be re-sampled in 2002 for the same set of constituents as sampled during cycle 1 . The entire study unit extent of the glacial aquifer will be sampled during 2003 for the same list of constituents as sampled at ground water sites during cycle 1 . One or two lake cores will be collected to determine deposition history of trace elements and organic compounds using age dating techniques. Occurrence and distribution samples will be collected for total mercury in sediment, tissue and the water column at 8 surface water sites during 2002.

Two topical studies are planned for 2003 and 2004:

(1) The urban land use gradient study will assess the impacts of urbanization on the health of aquatic biota in the Milwaukee and lower Fox River urbanized area. The study will focus on assessing the health of watersheds with urbanized land use in the 10-30 percent range. Stream chemical, biological, and physical parameters will be measured and assessed against a calculated urban index.

(2) The Mercury topical study will assess the bioaccumulation of mercury in game-fish species. Total Mercury will be determined in axial muscle tissue, composited from 6-10 individuals taken at the same site. Axial muscle is the most relevant component for human health, and can be related to whole-body burdens for toxicity relevance regarding piscivorous wildlife. Sampling of Methyl Mercury and Total Mercury in water and unsieved streambed sediment at the fish sampling sites will yield useful data regarding exposure of the fish 
to Mercury. Instantaneous Methyl Mercury data from the water and sediment samples will help indicate the relative potential of a watershed to convert inorganic mercury to Methyl Mercury, a critical step in mercury bioaccumulation. Methyl Mercury is more effectively biomagnified in food chains, is the predominant species of mercury in fish, and is more toxic than inorganic mercury.

\section{REPORTS (July 2001-July 2002)}

Fitzpatrick, F., 2001, A comparison of multi-disciplinary methods for measuring physical changes in streams, AGU Monograph.
Fitzpatrick, F., 2001, Effects of riparian corridors and hydrology on agricultural stream biota, in AWRA Specialty Conference on Riparian Ecology, August, 2000.

Scudder, B., Stewart, J., 2001 Algae of agricultural benchmark streams in Eastern Wisconsin-Western Lake Michigan Drainages, USGS Water Resources Investigations Report 96-4038-A, 46 p.

Robertson, D., Saad, D., and Wieben, A., 2001, An alternative regionalization scheme for defining nutrient criteria for rivers and streams, U.S. Geological Survey Water Resources Investigations Report 01-4073, 57 p.
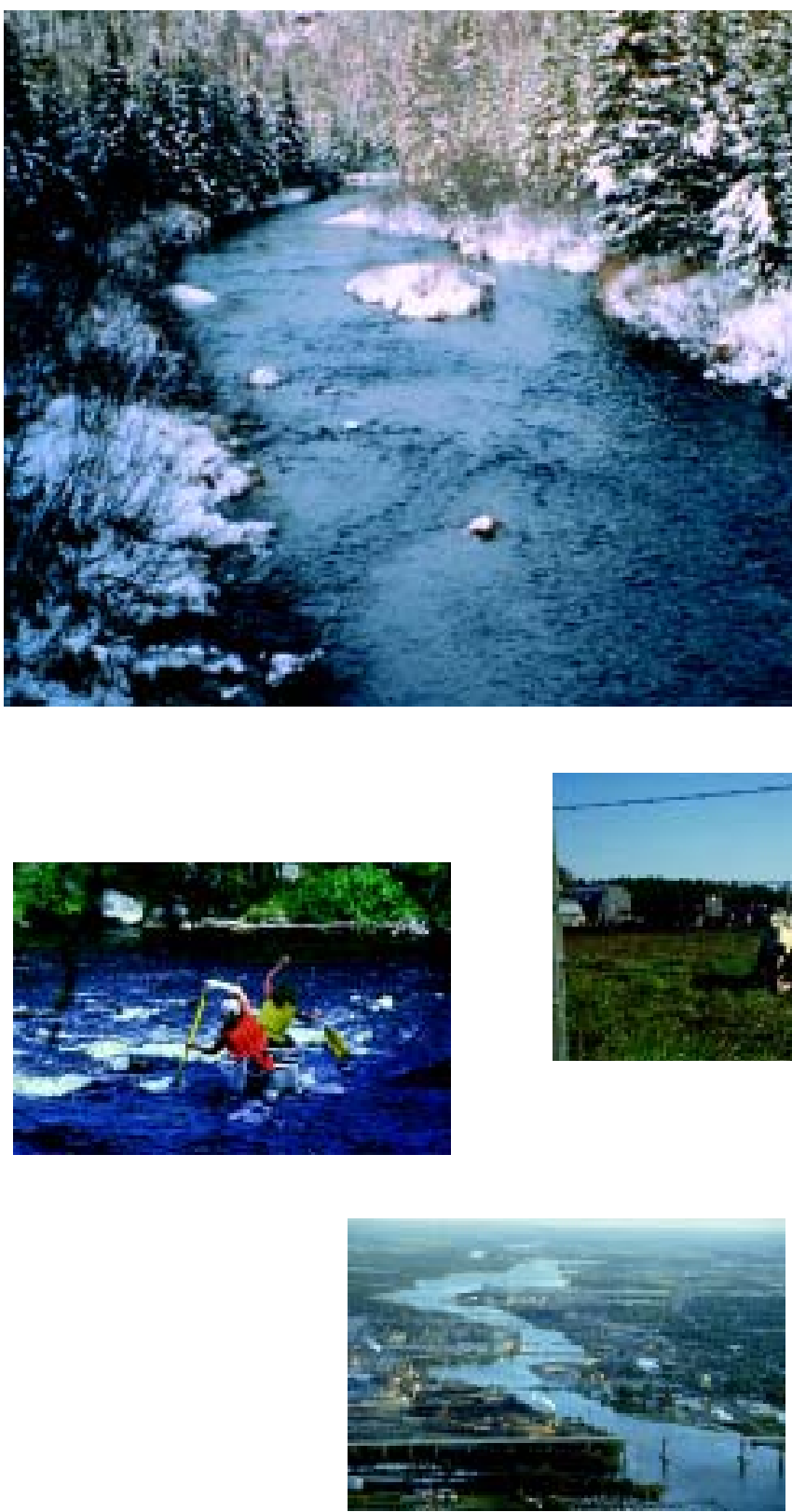
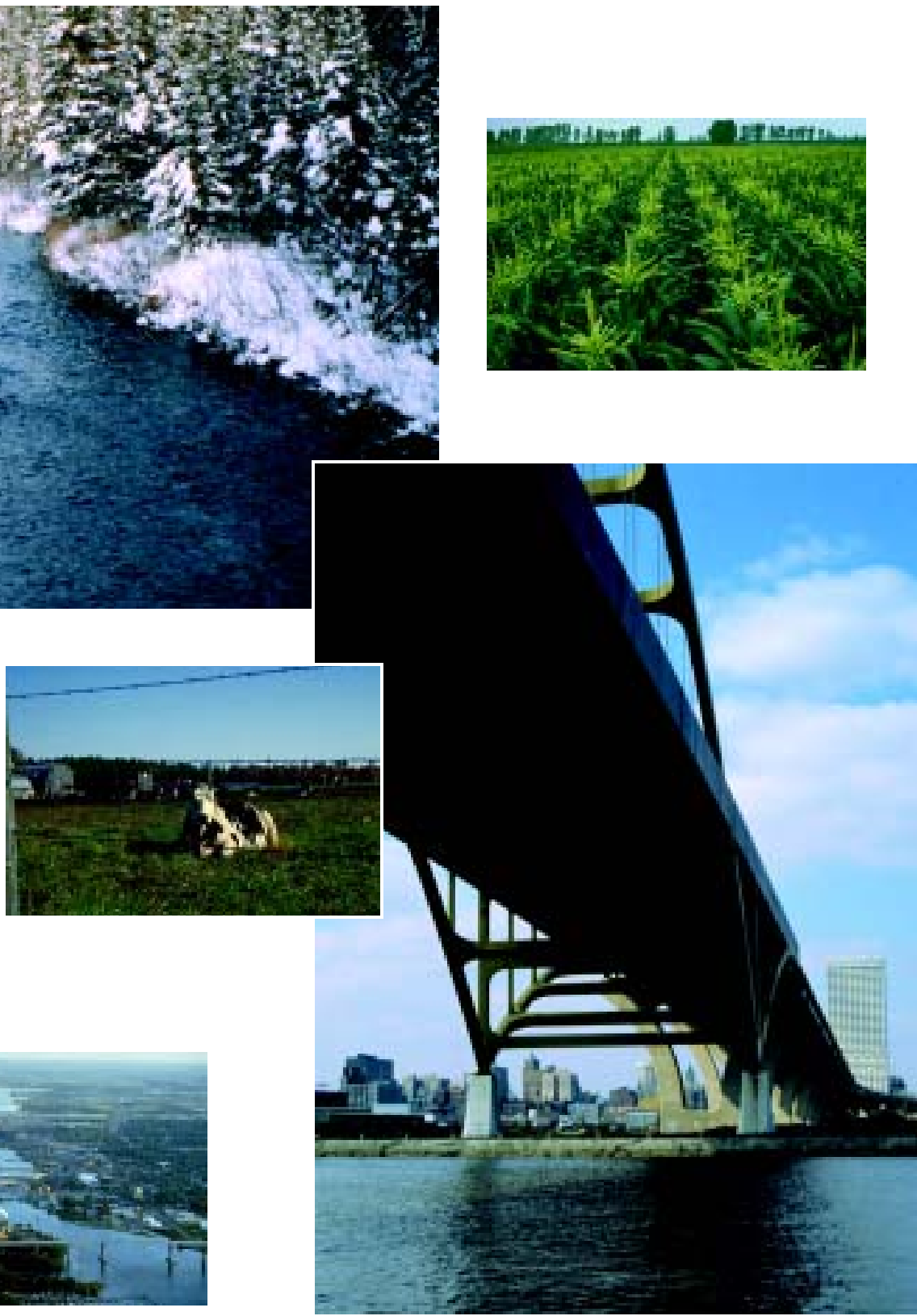


\section{UPPER ILLINOIS RIVER BASIN NATIONAL WATER- QUALITY ASSESSMENT (NAWQA)}

\section{COOPERATOR:

\author{
U.S. Geological Survey,
} Reston, Virginia}

\section{PROJECT CHIEF:}

Kevin D. Richards

\section{LOCATIONS:}

Upper Illinois River Basin in Illinois, Indiana, and Wisconsin

\section{PROJECT NUMBER:}

WI 17402

PERIOD OF PROJECT:

October 1996-Continuing

\section{PROBLEM}

Growing populations throughout the United States have resulted in increased development and use of our water resources. As our water resources become stressed, decisions on how to effectively utilize and manage these resources will need to be made. These decisions must be based on accurate assessments of the quality of the water resource and the factors affecting its use.

\section{OBJECTIVE}

The long-term goals of the NAWQA project are to determine the water quality of the streams and aquifers in the Upper Illinois River Basin (UIRB), determine the presence or absence of any trends in the water quality, and provide an understanding of the link between natural and anthropogenic factors and observed water quality. Specific goals are to: (1) determine the occurrence and spatial distribution of a broad array of water-quality constituents in ground and surface water and streambed sediments, (2) determine the occurrence of contaminants in selected target taxa, (3) evaluate the aquatic habitat and community structure of streams in the study unit, (4) assess the effects of urbanization on surface-

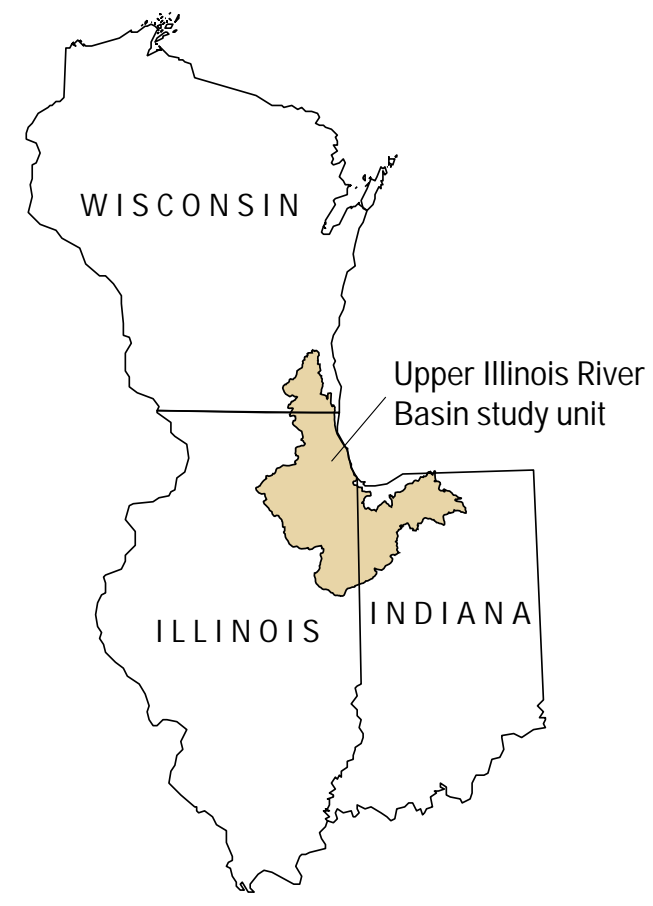

water quality in selected stream reaches, (5) evaluate the sources and transport of selected hydrophilic compounds in agricultural settings, and (6) assess the influence of land use on shallow ground-water quality in selected land-use settings.

\section{APPROACH}

The foundation of the study approach is based upon identifying relatively homogeneous areas of specific land-use and environmental characteristics. Identification of these areas was accomplished by overlaying digital coverages of land use and various environmental variables using a geographic information system (GIS). Sampling sites completely contained in these relatively homogeneous areas (indicator sites) were incorporated into a nested design of surface-water, streambed sediment, and biological sampling. The sampling strategy consists of a retrospective analysis of available waterquality data (1997-1999), followed by a high (1999-2001) and then a low-phase (2002-2006) datacollection effort. Monitoring of basic fixed sites (BFS) in selected areas (indicator sites), as well as downstream sites draining heterogeneous land uses and environmental characteristics (integrator sites), are being conducted. These sites will be sampled monthly and 
augmented with event-related samples. A subset of these sites will be extensively sampled for pesticides and volatile organic compounds. Pesticide samples will be collected approximately biweekly during the early to mid-summer period and less frequently during the rest of the year. Volatile organic compound samples will be collected weekly during the winter and less frequently during the rest of the year. Other program components include an urban gradient study to evaluate the relation between community (fish, algae, and invertebrates), habitat structure, land-use practices, and environmental factors. Ground-water studies include a study-unit survey and two land-use studies.

The land-use survey studies the effects of land use on ground-water quality through sampling in specific relatively homogeneous areas (1999 and 2000). A study unit survey provides an indication of water-quality conditions of the major aquifer (Silurian-Devonian) in the study unit.

\section{PROGRESS (July 2001 to June 2002)}

The GIS coverages will continue to be compiled and archived including: labeling the clustered Landsat data, wetlands data from the WISCland inventory, Natural Resource Inventory, Toxic Release Inventory, etc. Data archiving for data collected during the HIP (1999-2001) continues.

Land-use gradient special study-Open File Data report was approved for publication. The retrospective journal article "Urbanization influences on aquatic communities in northeastern Illinois streams" was prepared, undergone colleague review and the comments were incorporated. Data analysis and interpretation are ongoing for the proposed journal article "Ecological responses to physical and chemical changes related to urbanization in the Upper Illinois River Basin.”

\section{PLANS (July 2002 to June 2003)}

Three surface-water trend sites will be monitored for continuous flow and sampled 8 to 10 times a year for field parameters, pesticides, nutrients, selected ions, and suspended sediment.

Data from the high-intensity phase will continue to be analyzed and the results of analyses compiled in reports.

Ecological sampling will be conducted at the surface water trend sites in August 2002.

A number of publications are planned related to the ecological data collected and the land use gradient study.

\section{REPORTS}

Sullivan, D.J., 2000, Nutrients and suspended solids in surface waters of the Upper Illinois River Basin in Illinois, Indiana, and Wisconsin, 1978-97: U.S. Geological Survey Water-Resources Investigations Report 99-4275, $57 \mathrm{p}$.

Fitzpatrick, F.A., Colman, J.A., and Arnold, T.L., 1998, Surface water-quality assessment of the Upper Illinois River Basin in Illinois, Indiana, and Wisconsin: spatial distribution of geochemicals in the fine fraction of streambed sediment, 1987: U.S. Geological Survey WaterResources Investigations Report 98-4109, 89 p.

Sullivan, D.J., Stinson, T.W., Crawford, J.K., and Schmidt, A.R., 1998, Surface-water quality assessment of the Upper Illinois River Basin in Illinois, Indiana, and Wisconsin-Pesticides and Other Synthetic Organic Compounds in Water, Sediment, and Biota, 1975-90: U.S. Geological Survey Water-Resources Investigations Report 96-4135, 131 p.

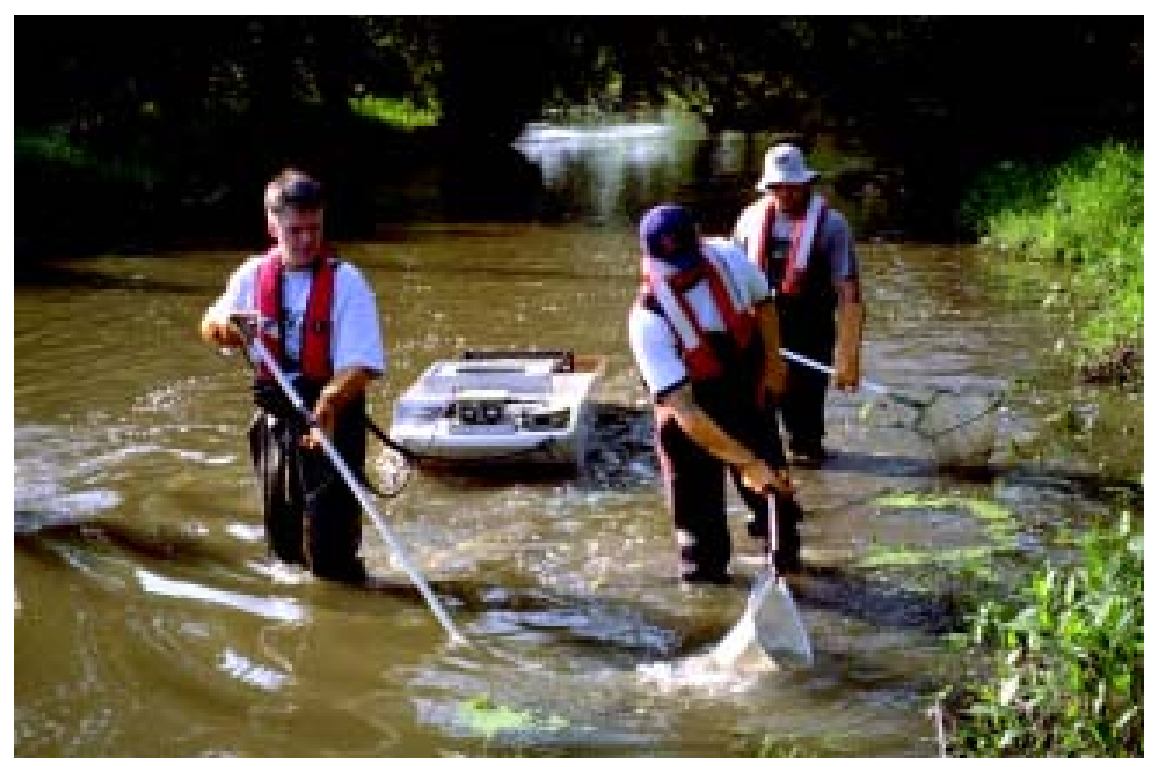

Fish shocking on the Des Plaines River at Russell, Illinois (USGS Station ID 05527800). 


\section{NATIONAL WATER-QUALITY ASSESSMENT (NAWQA) SPECIAL}

\section{COOPERATOR: \\ U.S. Geological Survey, Reston, Virginia}

\section{PROJECT CHIEF:}

Charles A. Peters

\section{LOCATIONS:}

Support of NAWQA National

Leadership and Synthesis Teams

\section{PROJECT NUMBER:}

WI 17403

\section{PERIOD OF PROJECT:}

October 1996-Continuing

\section{PROBLEM}

Growing populations throughout the United States have resulted in increased development and use of our water resources. As our water resources become stressed, decisions on how to effectively utilize and manage these resources will need to be made. These decisions must be based on accurate assessments of the quality of the water resource and the factors affecting its use.

\section{OBJECTIVE}

Since 1991, USGS scientists with the NAWQA program have been collecting and analyzing data and information in more than 50 major river basins and aquifers across the Nation. The goal is to develop longterm consistent and comparable information on streams, ground water, and aquatic ecosystems to support sound management and policy decisions. The NAWQA program is designed to answer these questions: (1) What is the condition of our Nation's streams and ground water?, (2) How are these conditions changing over time?, and (3) How do natural features and human activities affect these conditions?

\section{APPROACH}

Western Lake Michigan (WMIC) NAWQA Study Unit scientists cover a range of disciplines, including hydrology, geology, geomorphology, biology, chemistry, geographic information systems, database management, and statistics. WMIC Scientists have provided support to the NAWQA National Leadership and Synthesis Teams (NLT and NST) on a variety of topics that include: (1) Ground-water sampling protocol development, (2) Development of habitat sampling protocol, (3) Instruction at NAWQA Training And Methods Shakedown (TAMS), (4) Membership on the National Data Synthesis Team (DST), (5) Leading the NAWQA study unit archive process, and (6) Work with the Ecological Synthesis Team (EST) on the development of a biological database (BioTDB).

\section{PROGRESS (July 2001 to June 2002)}

Participated in archive reviews of the Long Island Coastal, Puget Sound and Upper Mississippi NAWQA study units. Study unit database manager serves as the Northeast Region study unit representative to the DST and participate in meetings and conference calls. WMIC study unit biologist revised the users manual for the biological database that is available on the Ecological Synthesis Teams website. Instructed habitat protocol at TAMS training in April to NAWQA Cycle II study unit biologists and technicians. Revised the groundwater protocol for colleague review.

\section{PLANS (July 2002 to June 2003)}

Incorporate review comments to the groundwater protocol and complete final draft. Continue involvement with the DST and conduct an archive review of a Southeastern Region NAWQA study unit. Maintain and update the NAWQA habitat protocol. Assist the EST with analysis and synthesis of NAWQA Cycle I Urban Land Use Gradient Study data. 


\section{DEMONSTRATION OF SUBMERGED VANES, FISH CREEK}

\begin{tabular}{|l|}
\hline COOPERATORS: \\
Wisconsin Department of Natural \\
Resources \\
Bayfield County \\
U.S. Fish and Wildlife Service \\
PROJECT CHIEF: \\
Faith A. Fitzpatrick \\
LOCATION: \\
Bayfield County \\
PROJECT NUMBER: \\
WI 19300 \\
PERIOD OF PROJECT: \\
July 2000 to September 2003 \\
\hline
\end{tabular}

\section{PROBLEM}

North Fish Creek has accelerated erosion and sedimentation problems that have potentially negatively impacted a highly valued fishery resource. Previous USGS studies identified bluff erosion along the upper main stem as the major source of sediment to downstream reaches. Bioremediation techniques for bluff stabilization were attempted but failed. Erosion control techniques are limited because of the remoteness of the site and lack of access.

\section{OBJECTIVES}

The main goal of this study is to demonstrate the ability of an in-stream restoration technique (submerged vanes on the channel bed) to reduce bluff erosion along a flashy, high-energy stream, and ultimately reduce subsequent sedimentation problems in North Fish Creek and potentially Lake Superior. Reducing sediment loads of Lake Superior tributaries is important not only for protecting or restoring aquatic habitat, but also for dredging issues.

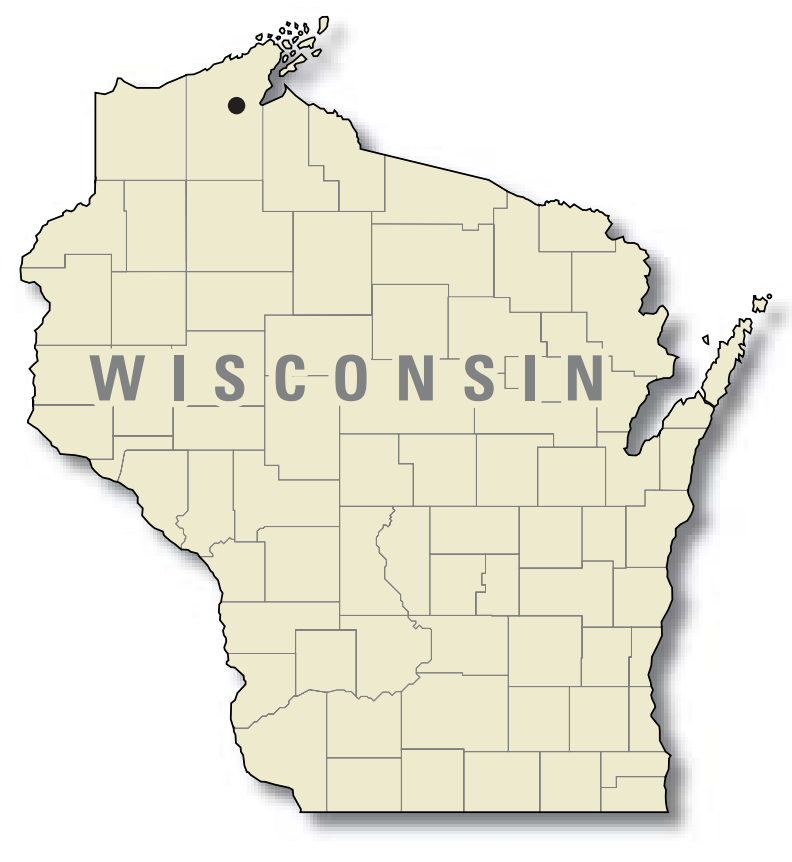

\section{APPROACH}

Submerged vanes were installed in the channel bed at two eroding bluff sites along the upper main stem of North Fish Creek in the summer of 2000 and 2001. The number, size, and layout of the vanes depend on the channel morphology, velocity, and depth at a meander bend. Typically, about 15 vanes are installed in groups of one to three. Vanes modify the secondary flows that cause erosion along the toe of a bank in a meander bend. Vanes stabilize a channel reach without inducing changes upstream or downstream of that reach. The vanes are not visible in time (they become buried by depositing sediments yet remain effective), and aid the stream in doing the work by redistributing the flow energy to produce a more uniform cross-section without an appreciable increase in the energy loss through the reach.

Monitoring the success of the study will be conducted through surveys of the bluff face, streamflow, and channel conditions before, during, and after installation of the submerged vanes. The bluff and channel will be resurveyed after flood events. The bluff surveys 
will be used to compare pre- and post-installation bluff retreat rates. Channel cross section surveys will be conducted at the site and in upstream and downstream locations to quantify changes in the shape and location of the channel. A streamflow-gaging station will be reactivated downstream of the site to properly quantify flood magnitudes experienced during the demonstration. Stage recorders will be installed at the bluff sites.

\section{PROGRESS (July 2001 to June 2002)}

Submerged vanes were installed at the second site. Bluff and channel surveys were conducted at both sites.
Streamflow was monitored at a gage downstream of both sites. Stage data were collected at both bluff sites. A master's thesis was published on installation and monitoring of vanes at the first site.

\section{PLANS (July 2002 to June 2003)}

Bluff and channel surveys will be conducted at both sites following major floods. Stage data will be collected at both sites. Streamflow data will be collected at a USGS gaging station downstream of both sites.

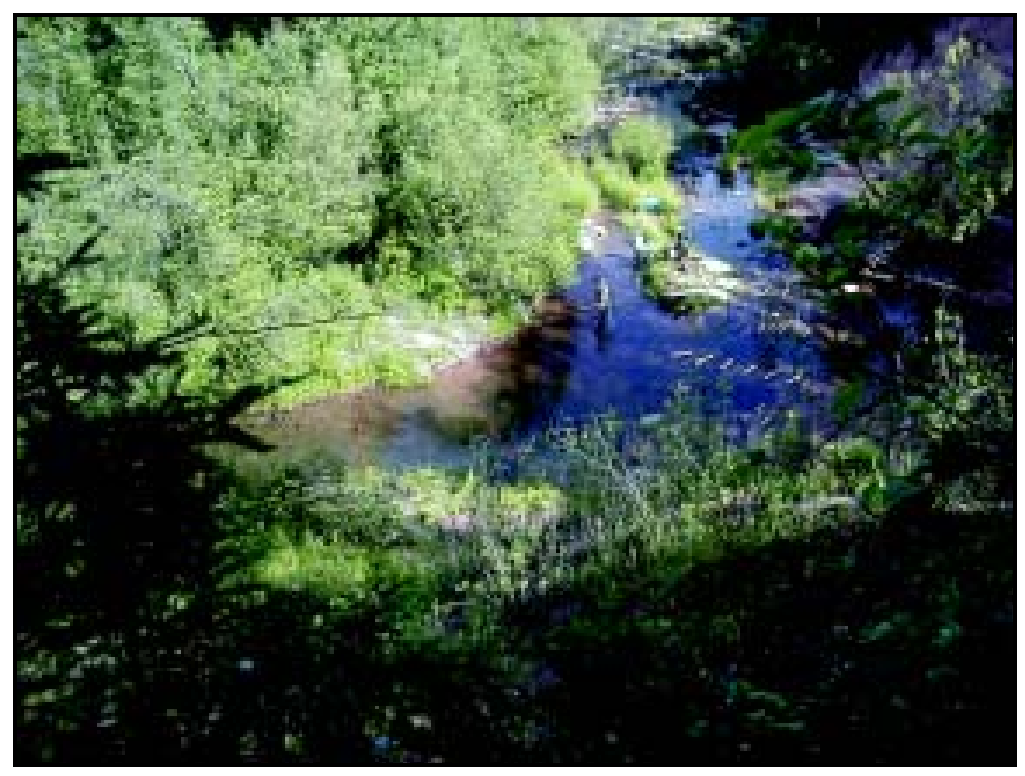

Placement of submerged vanes (white) at bluff site 1, Fish Creek (photo taken in 2001). 


\section{HYDROLOGIC LITERATURE SEARCH AND DIGITAL DATA COMPILATION OF CAMP WISMER AND PROPOSED HYDROLOGIC INVESTIGATION OF POTENTIAL SOURCE AREAS OF CONTAMINATION AT CAMP WISMER}

\begin{tabular}{|l|}
\hline COOPERATOR: \\
Wisconsin National Guard \\
PROJECT CHIEF: \\
Bernard N. Lenz \\
LOCATION: \\
Camp Wismer, near Hayward \\
PROJECT NUMBER: \\
WI 19500 \\
PERIOD OF PROJECT: \\
October 2001-February 2002 \\
\hline
\end{tabular}

\section{PROBLEM}

Camp Wismer covers nearly 3,600 acres in northwest Wisconsin about 9 miles northwest of the city of Hayward. Camp Wismer has been the site of training for the Wisconsin Army National Guard (WI-ARNG) since May 1986. The area is largely wooded and interlaced with unpaved forest roads. The majority of the activities of the WI-ARNG occur in the 124.4 acres owned by the U. S. Government on the western most portions of Camp Wismer and specifically within 4 areas. These include a 6.1-acre firing range, a 13.4-acre vehicle maneuvering area, a 1-acre fenced engineering exercises (Bailey bridges training) area, and a 0.3-acre sand pit quarry. The eastern 3,360 acres of Camp Wismer is leased from Sawyer County and used only for field orientation exercises. Prior to it being designated a military installation, parts of Camp Wismer were once occupied by small farms and homesteads, many of which have reverted back to forest.

\section{OBJECTIVE}

The National Guard Bureau (NGB) has requested the Water Resources offices of the USGS define and document the hydrology, hydrogeology, and the pres-

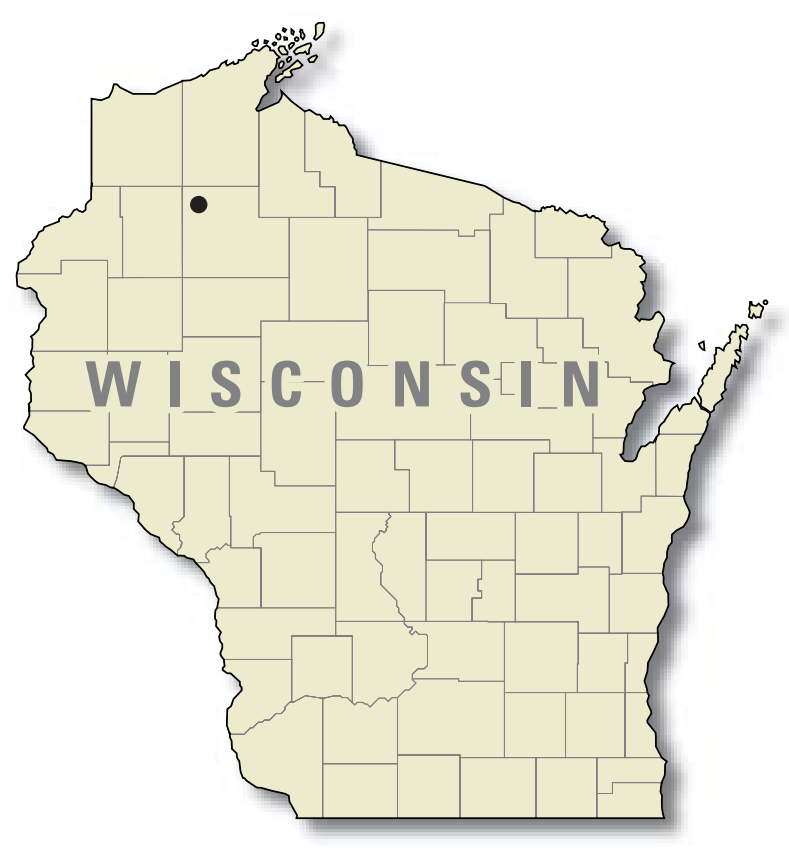

ence or absence of contamination in the ground water and surface water on military installations. Phase I of the project is to gather all available information on the water resources of the Camp and prepare a phase II study to fill in the gaps of missing data.

\section{APPROACH}

Available hydrologic data on Camp Wismer will be assembled and include GIS coverages, Well Log data, USGS and EPA database retrievals, atmospheric deposition data, and the Wisconsin State Historical Land Survey data. Phase I results are presented in letter along with a CD containing the hydrologic data and all GIS coverages. A proposal to perform work to fill in missing or incomplete hydrologic data on the installation was prepared.

PROGRESS (July 2001 to June 2002)

Project complete.

\section{PLANS (July 2002 to June 2003)}

Possible watertable ground-water monitoring in water year 2003 to fill in holes in data. 


\section{NATIONAL ENVIRONMENTAL METHODS INDEX}

\section{COOPERATOR:}

U.S. Environmental Protection Agency

PROJECT CHIEF:

Daniel J. Sullivan

\section{LOCATION:}

United States

PROJECT NUMBER:

WI 21006

PERIOD OF PROJECT:

October 1999-Continuing

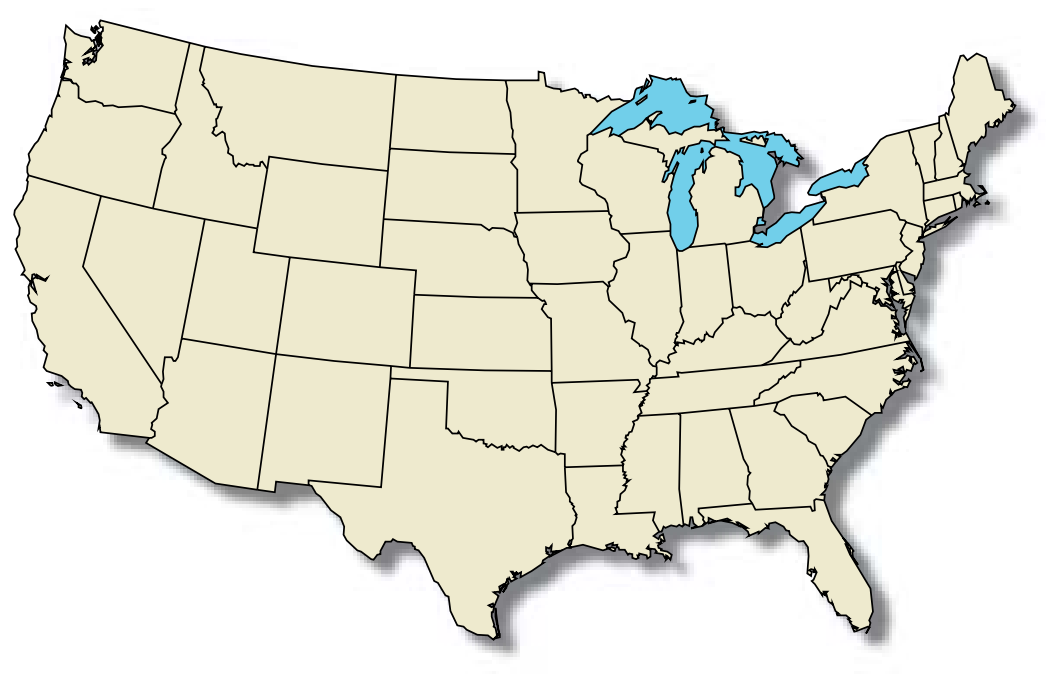

\section{OBJECTIVE}

The selection of analytical methods is a critical component of the planning process for environmental monitoring programs. With NEMI you can compare methods at a glance and find the method that best meets your needs. NEMI also allows you to use and share monitoring data among different agencies, using different methods at different times.

\section{APPROACH}

NEMI is a clearinghouse of environmental monitoring methods. The NEMI database contains method summaries of field and lab protocols for regulatory and non-regulatory water quality analyses. It is searchable over the World Wide Web, providing you with up-todate methods information through a standard Internet connection and browser. 


\section{PROGRESS}

To date, NEMI contains more than 650 chemical, immunoassay, physical, microbiological and radiochemical methods. NEMI's data fields include detection levels, bias, precision, and other Quality Assurance/Quality Control requirements that will enable you to document and report on data quality. You can search NEMI by: (1) Chemical/biological parameter; (2) Method source; (3) Metadata (precision, accuracy, detection level, etc.) Instrumentation; and (4) Method.

\section{PLANS}

During FY2003, plans for NEMI include adding methods to the database, including methods for field collection and new technologies. The web interface will continue to be refined, allowing users quicker and easier access to data. The NEMI workgroup will continue to work with the National Methods and Data Comparability Board to further enhance NEMI's usefulness to the environmental monitoring community. 


\section{NEOPIT MILL POND SEDIMENTATION AND SEDIMENT CHEMISTRY STUDY}

\section{COOPERATOR: \\ Menominee Indian Tribe of Wisconsin \\ PROJECT CHIEF: \\ Faith A. Fitzpatrick \\ LOCATION: \\ Neopit, Menominee Indian Reservation \\ PROJECT NUMBER: \\ WI 21101 \\ PERIOD OF PROJECT:}

February 2001 to June 2003

\section{PROBLEM}

The dam at the Neopit Mill Pond, Neopit, Wiscon$\sin$, Menominee Reservation, may be removed. The Menominee Tribe needs information on the volume, texture, and chemistry of sediment stored behind the dam. The pre-dam channel of the West Branch Wolf River is not known. This information is needed for sound decision-making involving the potential dam removal and subsequent stream restoration.

\section{OBJECTIVE}

The project objectives are to: (1) establish pre-dam topography and volume of sediment in the Mill Pond, (2) define the texture, and organic and trace element chemistry of the post-dam sediment in the Neopit Mill Pond, and (3) identify the pre-dam channel of the West Branch of the Wolf River.

\section{APPROACH}

Water depth and soft sediment depth will be measured by use of sounding poles at approximately 13 cross sections. Land surveys of banks and islands bisected by cross sections will be conducted. The USGS will provide training for personnel from Environmental

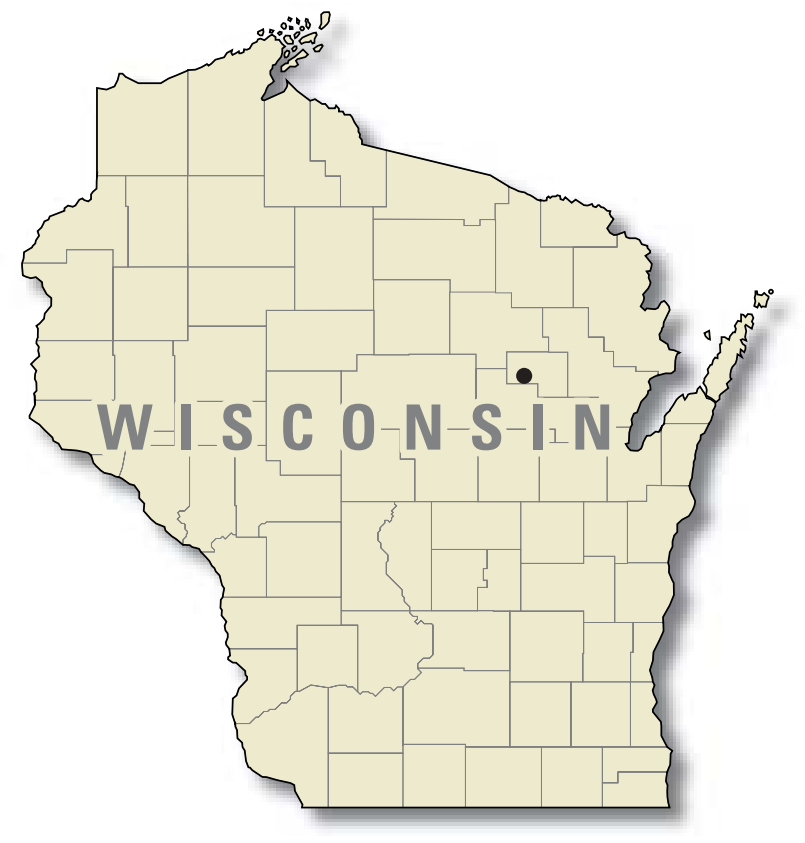

Services, Menominee Tribe, to conduct the soundings. Approximately one to three cores will be collected per cross section with a piston corer and geoprobe. Selected cores will be subsampled for analysis of particle size,

${ }^{137} \mathrm{Cs}$ dating, water content, trace elements, and organic contaminants. Samples will be submitted to the USGS National Water-Quality Laboratory for analyses of trace elements, organic contaminants, and ${ }^{137} \mathrm{Cs}$ dating. Particle size samples will be submitted to the USGS particle size laboratory in Iowa. Water content will be measured at the USGS in Middleton, Wisconsin. Approximately 10 percent of the samples will be submitted for quality assurance. Results will be published as a USGS Open-File Report or Water-Resources Investigations Report.

\section{PROGRESS (July 2001 to June 2002)}

Remaining samples were submitted for analysis of trace elements, organic chemicals, and radiometric age dating. Menominee Tribe Personnel completed bathymetric surveys of the millpond. Data analysis and report writing commenced.

\section{PLANS (July 2002 to June 2003)}

Finish data analysis and report writing. 


\section{ST. CROIX NATIONAL SCENIC RIVERWAY-NUTRIENT AND SEDIMENT LOADING AND LONG-TERM WATER-QUALITY MONITORING}

\begin{tabular}{|l|}
\hline COOPERATORS: \\
National Park Service Joint Water \\
Quality Commission of Danbury; \\
St. Croix Chippewa Indians \\
of Wisconsin \\
PROJECT CHIEF: \\
Bernard N. Lenz \\
LOCATION: \\
St. Croix National Scenic \\
Riverway \\
PROJECT NUMBERS: \\
WI 21202, 00301 \\
PERIOD OF PROJECT: \\
October 1998 to September 2001 \\
\hline
\end{tabular}

\section{PROBLEM}

The St. Croix National Scenic Riverway (NSR) contains more than 60 state and federally listed endangered and threatened species, indicating that it provides one of the few remaining relatively well-preserved and biologically diverse aquatic environments in the region. The NSR has a very active management and scientific community and a rich research history. Although the water quality is generally considered to be good in the Upper St. Croix and Namekagon Rivers, activities in the tributaries and their watersheds are affecting the overall health of the St. Croix NSR. In the Lower St. Croix River, including Lake St. Croix, nutrient levels are elevated. Recreational and developmental pressures are intensifying in the watershed. Recreational use has doubled since 1973 to nearly one million visitors yearly. Due to its proximity to the Minneapolis/St. Paul metropolitan area, the Riverway will continue to experience increased use and developmental pressure from population growth in the counties adjacent to the Riverway.

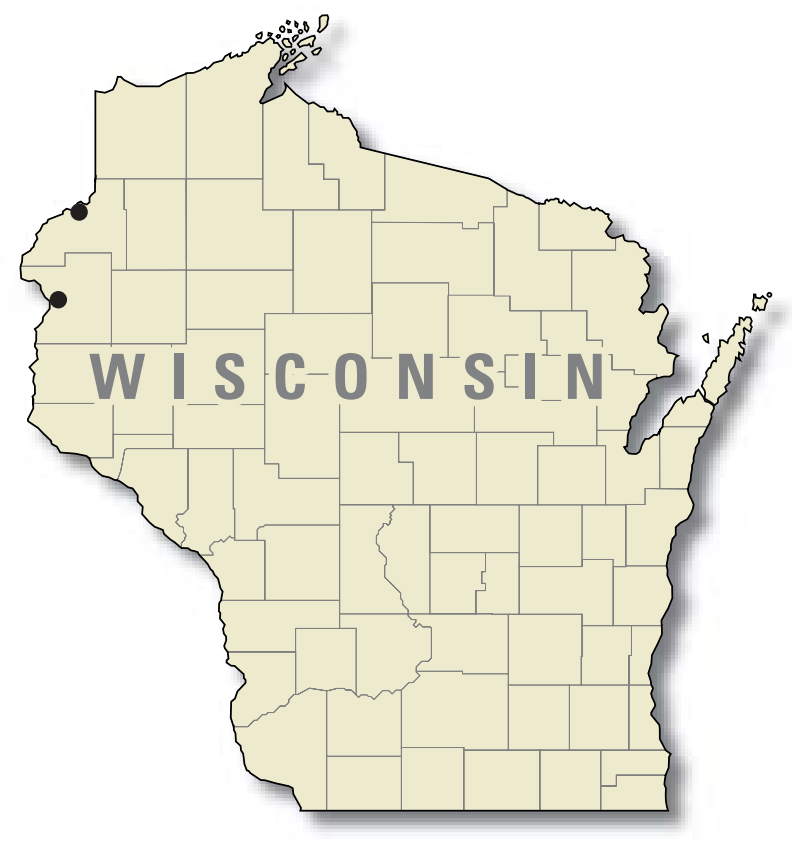

OBJECTIVE

The objectives of this project are to provide consistent, long-term water-quality monitoring at key sites on the St. Croix River and develop a long-term database to use to detect changes and protect the water resources of the St. Croix River.

\section{APPROACH}

21202_USGS/Joint Water Quality Commission of Danbury and St. Croix Chippewa Indians of Wisconsin-From October 2000 through September 2001, the USGS continuously monitored streamflow, and collected sediment and nutrient samples at the St. Croix River near Danbury. Historical long-term USGS waterquality data from the St. Croix River at Danbury will be summarized and compared to recent water-quality data and be presented in a fact sheet.

00301-USGS/NPS - Water quality data from the St. Croix River at St. Croix Falls will be summarized 
and compared to recent water-quality data and be presented in the fact sheet. Trends in streamflow and water quality of the St. Croix River at Danbury and at St.

Croix Falls will be summarized and presented in the fact sheet.

\section{PROGRESS (July 2001 to June 2002)}

Continuous streamflow monitoring and monthly water-quality sampling was completed in September 2001. Historical data has been gathered and analysis is ongoing. Annual progress reports are being supplied to the NPS throughout the project. Many new partnerships with scientists and agencies working in the St. Croix Basin have been developed. A heightened awareness of nutrient and sediment loading and these new relationships should lead to continued scientific interest and study in the St. Croix Scenic Riverway.

\section{PLANS (July 2002 to December 2002)}

A USGS Fact Sheet will be produced that relates historical long-term water quality and flow to recent water quality and flows.

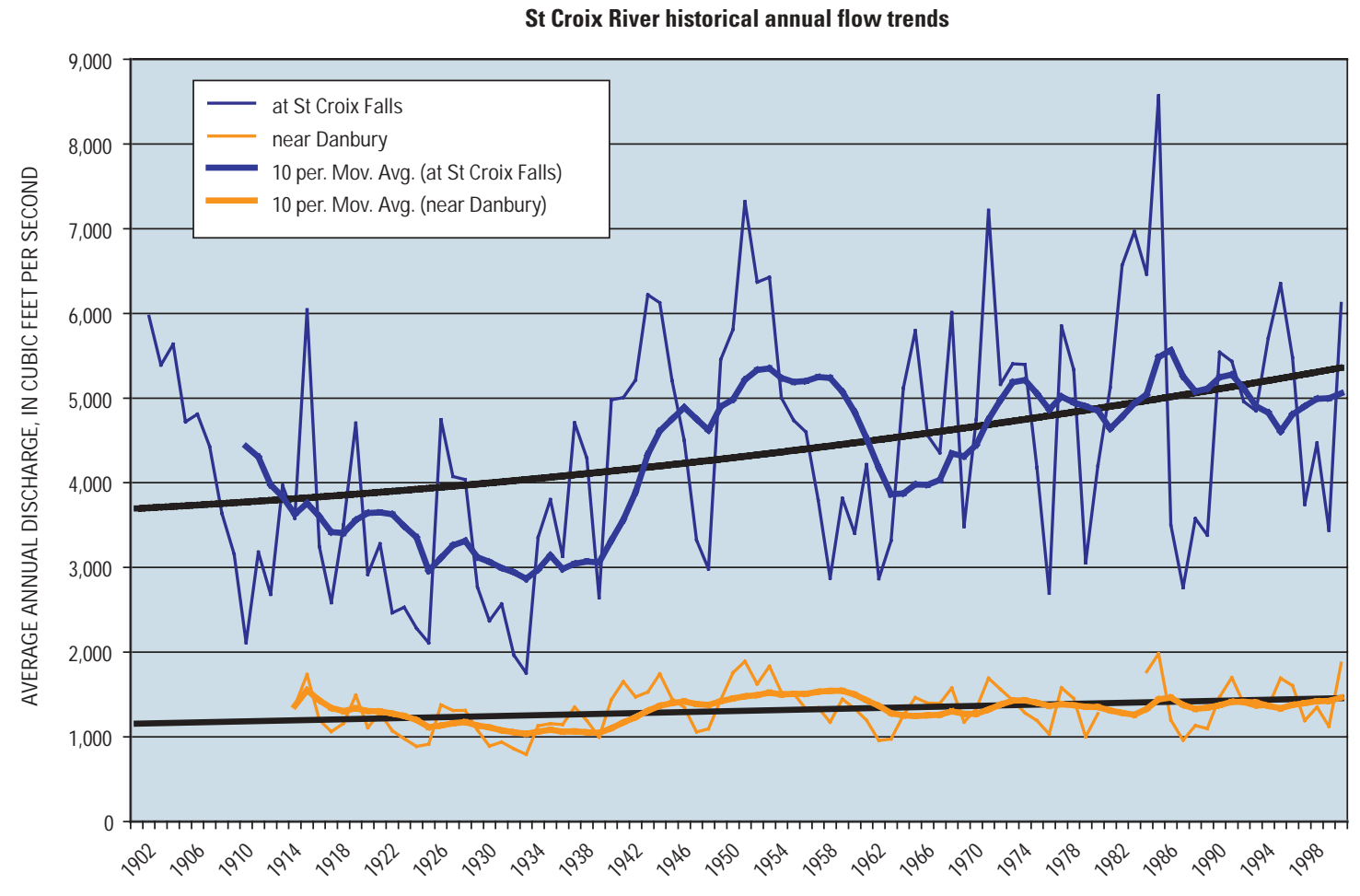

Trends in annual average streamflow for the St. Croix River at St. Croix Falls and near Danbury, Wisconsin. 


\section{WHITTLESEY CREEK HYDROLOGY STUDY}

\section{COOPERATOR:}

Bayfield County

PROJECT CHIEF:

Faith A. Fitzpatrick

\section{LOCATION:}

Bayfield County

PROJECT NUMBER:

WI 21500

\section{PERIOD OF PROJECT:}

May 1999 to June 2003

\section{PROBLEM}

Whittlesey Creek is considered an Outstanding Resource Water and Valued Lake Superior Ecosystem Member. This small watershed serves as spawning ground for 35 percent of Wisconsin's coho salmon population because of its consistent base flow and good water quality. However, like many Wisconsin tributaries to Lake Superior, aquatic habitat in Whittlesey Creek is possibly degraded because of accelerated runoff and associated sedimentation problems. In addition, the sources for the abundant baseflow in Whittlesey Creek are not very well understood. Recently, the mouth of Whittlesey Creek has been proposed as a National refuge for the re-establishment of Coaster Brook Trout. A hydrological analysis of streamflow in Whittlesey Creek is needed to identify potential present and future land-cover impacts on baseflow and flooding characteristics of the creek.

\section{OBJECTIVE}

Objectives are to: (1) quantify current streamflow characteristics for Whittlesey Creek floods, base flow,

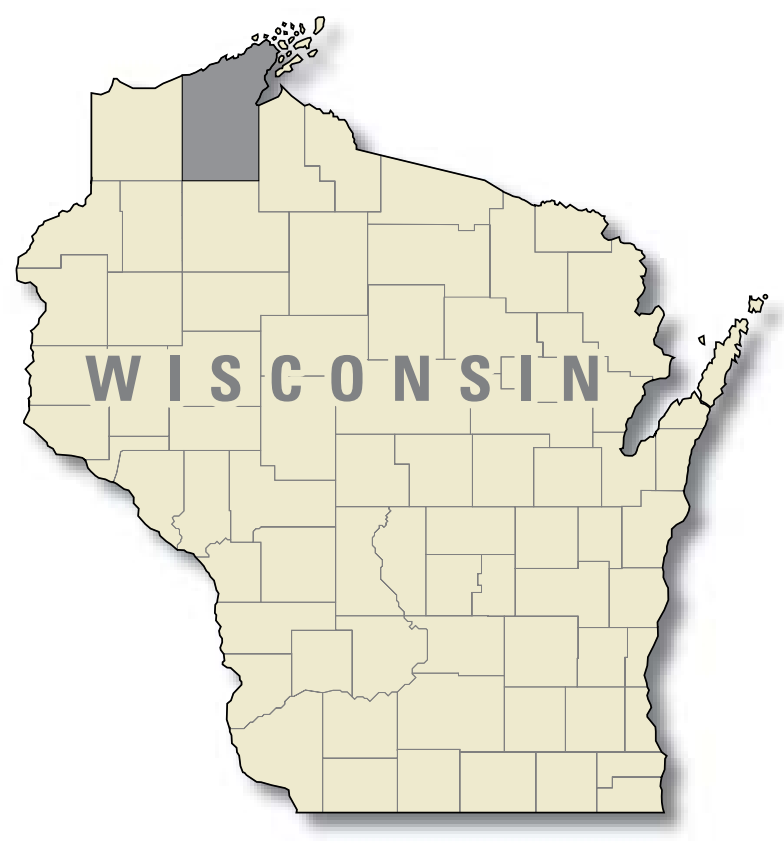

and seasonal fluctuations, (2) quantify contributions of runoff and ground water to streamflow, (3) identify ground-water recharge and discharge areas for Whittlesey Creek (identify contributions from glacial deposits vs. sandstone bedrock aquifers), (4) identify pre-settlement hydrologic conditions, (5) quantify how current land-cover characteristics affect flood and base-flow characteristics, (6) predict how future changes in land cover affect floods and base flow in Whittlesey Creek and (7) identify areas of the basin that contribute the most to flooding problems.

\section{APPROACH}

This study used an event-based rainfall/runoff model (SWAT) and two ground-water models (MODFLOW; GFLOW) to quantify base flow and flooding characteristics of Whittlesey Creek. Hydrologic field data also was collected to help refine and calibrate the models. The proposed study started in April 1999 with installation and operation of a streamflow and rainfall gaging station near the mouth of Whittlesey Creek and a survey of base-flow conditions (seepage run). In 
FY 2000-2001, additional field data was collected for the rainfall/runoff and ground-water models, GIS data for the rainfall/runoff model was gathered, and the models were compiled and calibrated. In FY 2002, a report on the modeling results will be written and published.

\section{PROGRESS (July 2001 to June 2002)}

Rainfall/runoff and ground-water models were completed. Results were presented to cooperator. A draft report was written.

PLANS (July 2002 to June 2003)

Publish report.

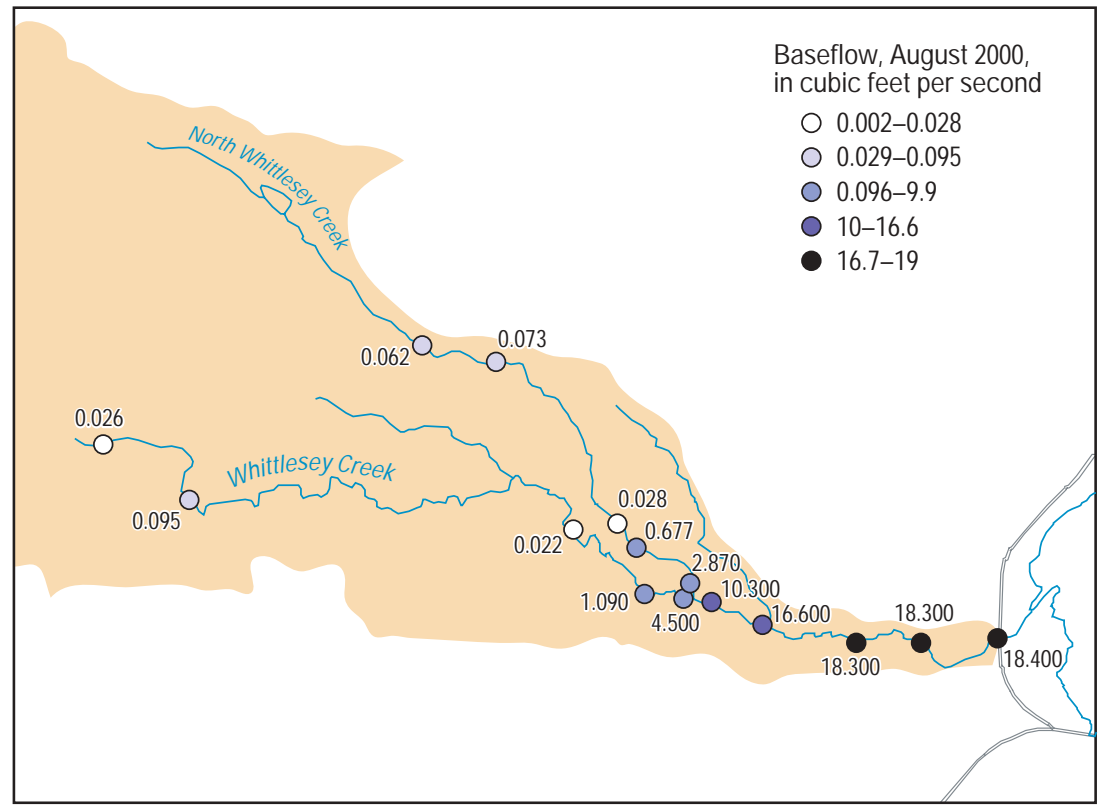

Whittlesey Creek base-flow measurements, August 2000. 


\section{HISTORICAL ECOSYSTEM RECONSTRUCTION AND POTENTIAL IDENTIFICATION OF EFFECTS OF PAST ECOSYSTEM PERTURBATIONS IN LAC COURTE OREILLES}

\section{COOPERATORS: \\ Lac Courte Oreilles Tribe; Wisconsin Department of Agriculture, Trade, and Consumer Protection}

\section{PROJECT CHIEF:}

Faith A. Fitzpatrick

\section{LOCATION:}

Lac Courte Oreilles, Sawyer County

PROJECT NUMBER:

WI 21700

PERIOD OF PROJECT:

October 1999 to September 2001

\section{PROBLEM}

There has been a potential increase in nutrient inputs and enhanced eutrophication in Musky Bay, Lac Courte Oreilles, Wisconsin in the last few decades. Historically, the Bay contained wild rice beds and was a major spawning ground for muskellunge, which make up a large portion of the Lac Courte Oreilles Tribe's diet. The Lac Courte Oreilles Tribe is interested in determining changes in historical nutrient inputs to Musky Bay, determining the source of the nutrients, and comparing these findings to historical nutrient inputs in other parts of Lac Courte Oreilles.

\section{OBJECTIVE}

The main objective is to reconstruct the ecosystem history of Musky Bay and an additional site within Lac Courte Oreilles with special emphasis on possible effects of cranberry farming and shoreline development using the sediment record. The principal focus is on the nutrient history (input and burial rates) that reflects management practices and possible watershed degradation. Another focus is to search for possible cranberry farming signatures including sulfur, uranium, and potassium associated with fertilizers, and copper associated with pesticides.

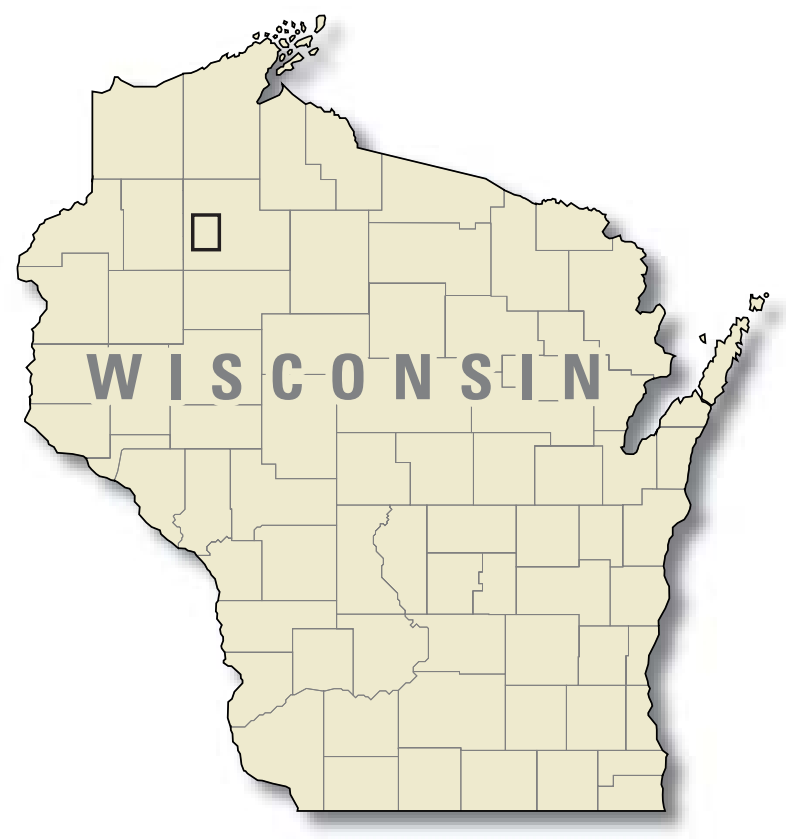

\section{APPROACH}

Several cores from Musky Bay and additional sites on the lake were collected in 1999 and 2001. Dates and sedimentation rates were calculated for 20 increments in the Musky Bay core (15 increments from an additional core) from analyses of ${ }^{210} \mathrm{~Pb},{ }^{226} \mathrm{Ra}$, and ${ }^{137} \mathrm{Cs}$. Total organic carbon and nutrient (nitrogen, phosphorus, biogenic silica) input and burial rates were calculated from dated sediment by combining measured concentrations of these nutrients and mass sediment accumulation rates. Diatom and pollen assemblages were examined by the Wisconsin Department of Natural Resources. Biogenic silica profiles were used as supporting evidence for diatom reconstructions and as an indicator of species shifts (largely from diatoms to nonsiliceous algae) in response to increased nutrient inputs. Forty-two geochemical parameters were measured.

\section{PROGRESS (July 2001 to June 2002)}

Lake sediment and soil samples were collected from Lac Courte Oreilles and surrounding areas for additional geochemical analysis. The report was written and submitted for review.

\section{PLANS (July 2002 to June 2003)}

Publish a Water-Resources Investigations Report and submit paired journal articles for publication. 


\section{MILWAUKEE METROPOLITAN SEWERAGE DISTRICT CORRIDOR STUDY}

\section{COOPERATOR: \\ Milwaukee Metropolitan \\ Sewerage District \\ PROJECT CHIEF: \\ Morgan A. Schneider \\ LOCATION: \\ Milwaukee County and parts of Waukesha, Washington, Ozaukee, and Racine Counties \\ PROJECT NUMBER: \\ WI 22500 \\ PERIOD OF PROJECT: \\ February 2001-Continuing}

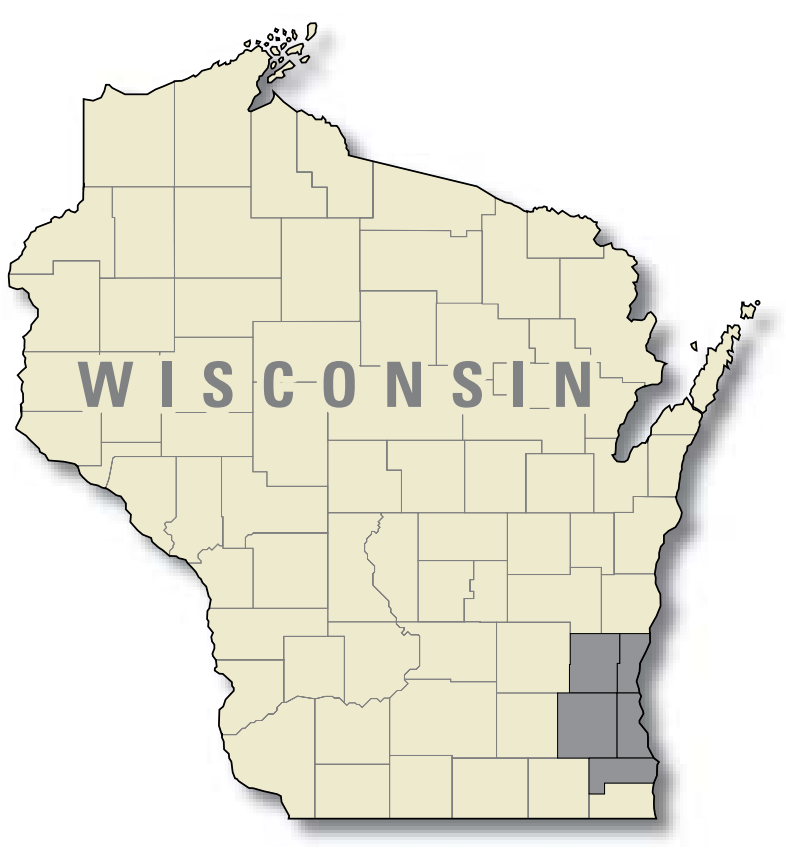

quette University, Wisconsin Lutheran College, and others.

\section{OBJECTIVE}

The primary objectives of the MMSD Corridor study include: (1) evaluating historic impacts and forecasting potential impacts of planned MMSD projects, (2) creating a comprehensive inventory of corridor conditions, (3) establishing a baseline assessment of existing watercourse and corridor conditions, (4) determining the existing and potential water-use objectives for watercourse reaches, (5) following up on flood control, habitat and water-quality improvement or protection projects to verify anticipated results, evaluate current technologies, and identify adjustments for future projects, and (6) providing long-term surveillance of stream and corridor conditions to monitor project impacts, track changes in impaired and unimpaired reaches, provide additional inventory information, and allow early detection of newly impaired reaches. 


\section{APPROACH}

There is a three-phase approach to the MMSD Corridor study. Phase I will include the development of a data warehouse and evaluation of analytical procedures. A data warehouse will be compiled from different data sets with the purpose of assembling data from within the corridor study area. The assembled data will then be analyzed to summarize existing conditions and identify data gaps and future data needs. Phase II will consist of a baseline inventory of water-quality conditions in the MMSD study area. An intensive data-collection and analysis effort will be made to fill in data gaps and update historic data to define the existing characteristics of the watercourses and corridors and serve as the basis for future impact evaluations and trend analyses. Phase III will be the development of a long-term inventory of water-quality data and maintenance of the data warehouse. The data collected as part of field activities and the data maintained in the data warehouse will be used to assess future impacts, measure the benefits of watercourse modifications and other watershed management efforts, and detect new watercourse concerns or impairments.

\section{PROGRESS (July 2001 to June 2002)}

Ongoing Steering Committee meetings keep members informed of project progress and provide a forum for feedback.

Data sets from MMSD, USGS, and USEPA have been incorporated into the data warehouse. Data sets from the WDNR have been compiled and prepared for loading into the data warehouse. Some hard copy data from WDNR has been converted into electronic format in order to load it into the data warehouse.

A literature review of studies and research reports in the MMSD study area has been completed, the results of which will be included in a report summarizing data in the data warehouse.

\section{PLANS (July 2002 to June 2003)}

Incorporation of more data sets including data from WDNR and various universities will continue.

"Canned queries" created with the query tool Oracle Discoverer for use by the Steering Committee and other internal users over the Internet will be improved.

GIS data sets for the study area will be compiled from various agencies into a GIS library. GIS data may be used at a later time with a yet-to-be-determined spatial tool to allow users to query for data from the data warehouse from a mapping interface.

Steering Committee meetings will continue. The MMSD Corridor study was the focus of one presentation at the May 2002 National Monitoring Conference held in Madison, Wisconsin.

A report summarizing data in the data warehouse will be written in the spring of 2003.

Planning for Phase II, baseline monitoring, will begin in the spring of 2003. Sampling will begin in the late spring or summer of 2003.

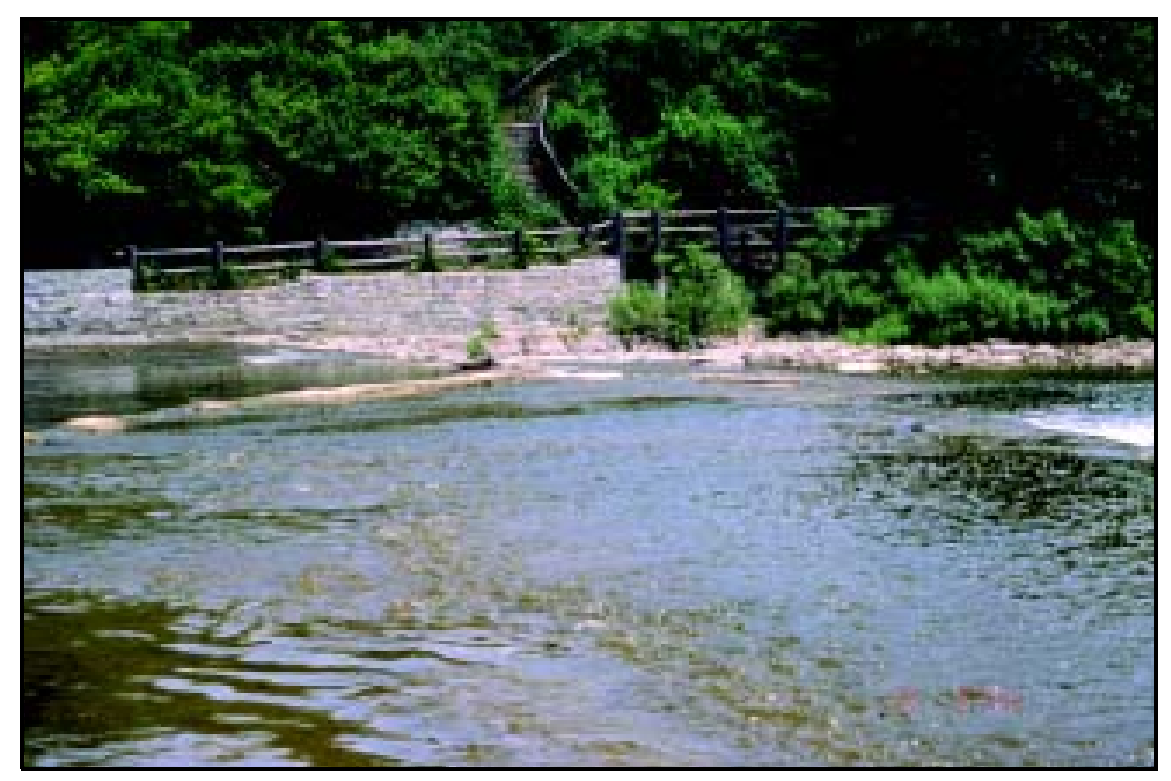

Milwaukee River at Estabrook Park, Milwaukee, Wisconsin (USGS Station ID 04087000). 


\title{
GREAT LAKES AQUATIC GAP
}

\section{COOPERATOR:}

\author{
U.S. Geological Survey, \\ Biological Resources Discipline

\section{PROJECT CHIEF:}

Jana S. Stewart

\section{LOCATION:}

Great Lakes States

PROJECT NUMBER:

WI 22600

\section{PERIOD OF PROJECT:}

September 2001 to June 2002

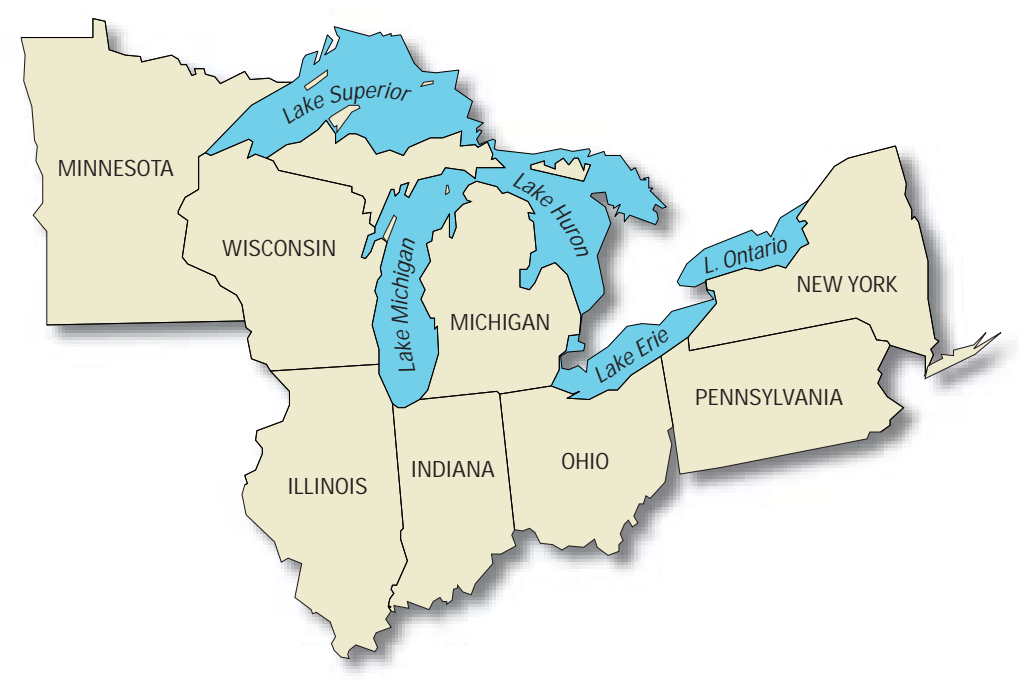

\section{PROBLEM}

An Aquatic Gap program is being proposed for the riverine systems of the Great Lakes Region including new projects in the States of Minnesota, Wisconsin, Illinois, Michigan, Indiana, and New York and integration of existing or completed projects in Ohio and Pennsylvania. A pilot study to develop a coastal component for Aquatic GAP is also being proposed for the Great Lakes Region. The Great Lakes are the largest system of freshwater on earth and provide habitat for a wide variety of aquatic organisms unique to these systems. The aquatic biodiversity of the region is being threatened due to increased population growth from urban expansion, more intensive agricultural practices, continued logging and coastal zone shoreline destruction.

\section{OBJECTIVE}

The objectives of this project are to (1) develop a multi-institutional, multi-state regional cooperative approach toward the development and use of Aquatic Gap data, (2) produce a contact list of key stakeholders and collaborators in the states of the Great Lakes Region, (3) produce a summary of existing fish and aquatic macroinvertebrate databases in the Great Lakes Region, (4) produce a summary of planned and existing thematic spatial data layers needed for Aquatic Gap for the Great Lakes Region, (5) review the Michigan Institute of Fisheries Research groundwater/surface water interaction model, (6) assess the feasibility and identify a pilot study area for conducting a coastal aquatic gap effort, and (7) develop a multi-year proposal for conducting Aquatic Gap in the Great Lakes Region.

\section{APPROACH}

The feasibility for conducting Aquatic Gap for both riverine and coastal systems will be assessed by summarizing the status and availability of existing data for each of the States, including fish and macroinvertebrate databases, spatial data layers related to physical characteristics of the land and in-stream habitat. An integrated approach will be developed for Aquatic Gap in the Great Lakes region in which common methods and protocols will be established and results will be comparable across the landscape. A list of stakeholders in the region will be developed and contacted for their input into this effort.

\section{PROGRESS (September 2001 to June 2002)}

A contact list of stakeholders was developed and stakeholders meetings were held in Michigan and Wisconsin. Existing aquatic biological databases and thematic spatial data layers were summarized for the Great Lakes States and the feasibility for conducting Aquatic Gap in the Great Lakes States was assessed. A multi-year proposal for conducting Aquatic Gap in the Great Lakes States and developing a Coastal Aquatic Gap pilot was developed.

\section{PLANS (June 2002 to May 2003)}

Ecological stream classifications will be developed for the states of Michigan and Wisconsin and aquatic biological databases will be developed for Michigan, Wisconsin, and New York. Projects will be conducted as individual State projects under the umbrella of the Great Lakes Aquatic Gap project. 


\section{KALAMAZOO RIVER GEOMORPHOLOGY STUDY}

\section{COOPERATORS:}

Michigan Department of Environmental Quality;

U.S. Environmental Protection Agency

\section{PROJECT CHIEF:}

Faith A. Fitzpatrick

\section{LOCATION:}

Allegan County, Michigan

PROJECT NUMBER:

WI 22700

PERIOD OF PROJECT:

October 2001 to March 2003

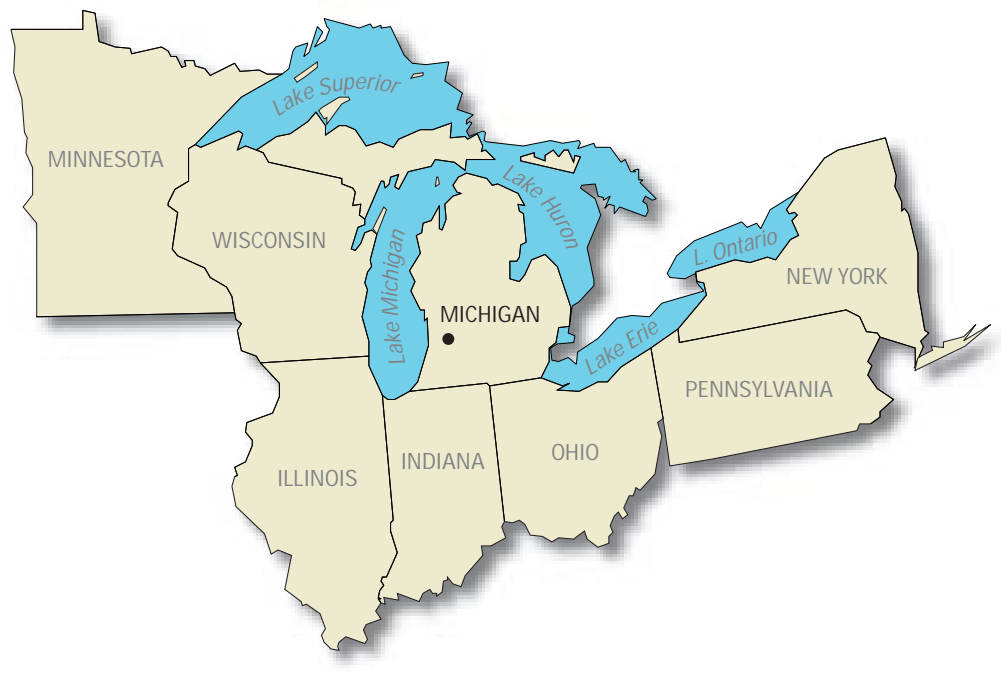

\section{PROBLEM}

The Kalamazoo River has been designated as a Federal Superfund Site from the city of Kalamazoo to its mouth at Lake Michigan. Fluvial deposits from a variety of environments related to the Kalamazoo River contain elevated concentrations of polychlorinated biphenyls (PCBs) from paper-mill carbonless copy paper production. There are four dams on the Kalamazoo River between Plainwell and Allegan. Pool levels behind the dams were lowered prior to state ownership in the late 1960s, exposing previously inundated sediment with elevated PCB concentrations. Dam superstructures were removed (leaving a sill) in 1987. PCB-laden sediment continued to be transported and deposited downstream of each dam as a new channel cut through the previously impounded reach. The USGS is currently collecting suspended sediment, bedload sediment data, and channel cross section data that will be used in a transport model of sediment movement simulating the effects of catestrophic removal of the dams. Rather than duplicating costs and field efforts that have already been completed, this study would use or build upon field data, GIS data, and numerical models applied by the USGS, other agencies, and consultants. Preliminary observations indicate that the previously inundated surfaces fall into at least two elevation categories. One appears to currently be functioning as a flood plain and the other, somewhat lower surface, appears to be functioning as a wetland. This has caused some definitional complexity in the cleanup criteria applicable to the exposed sediment. The upland soil category doesn't seem to fit because both surfaces are frequently inundated, increasing the risk of exposure of high $\mathrm{PCB}$ concentrations for a variety of aquatic life.

\section{OBJECTIVE}

The objectives of the study are to: (1) qualitatively describe the regional hydrologic conditions of the Kalamazoo River compared to other large Great Lakes tributaries in Michigan; (2) construct the longitudinal profiles and gradients for the Kalamazoo River from its headwaters to the mouth for conditions (a) without dams, (b) with dams in full operation, and (c) with dam sills removed; (3) identify reaches of the Kalamazoo 
River prone to lateral migration or avulsion circa (a) 1827 (b) 1938, (c) 1960, and (d) 2000 from Kalamazoo/Calhoun County line to its mouth at Lake Michigan; (4) measure bank stability for the Plainwell to Trowbridge Dam reach; (5) estimate channel development and stability for current conditions; (6) determine pre-dam channel elevation and planform dimensions; (7) determine permanence of engineered banks under current conditions, and (8) model bank and channel stability for the Plainwell to Otsego City Dam reach under scenarios of (a) catastrophic failure, (b) controlled removal with natural river channelization, and (c) controlled removal with designed channelization and/or rerouting.

\section{APPROACH}

The approach for this study involves field data collection and modeling by the USGS offices in Michigan and Wisconsin, as well as technical support from the U.S. Department of Agriculture, Agricultural Research Service. The approach includes: (1) conducting a literature review and describing the general watershed characteristics; (2) reviewing historical geomorphic data for the Kalamazoo River and determine if data are detailed enough to reconstruct pre-dam channel shape, substrate, and bed elevation; (3) quantifying the longitudinal profile of the Kalamazoo River from headwaters to its mouth (a) without dams, (b) with dams in full oper- ation, and (c) with dam sills removed and identifying reaches with slope changes and investigate possible causes for changes (anthropogenic/dams vs. geologic setting, historical relations with pre-glacial drainage); (4) determining channel planform/location for the Kalamazoo River from Kalamazoo/Calhoun County line to its mouth for the years 1827, 1938, 1960, and 2000; (5) evaluating digital representation of previously inundated surfaces for the Plainwell to Allegan reach of the Kalamazoo; (6) modeling bank stability under current conditions for the Plainwell to Trowbridge Dam reach; (7) conducting evaluation of channel stability under three scenarios for the Plainwell and possibly the Otsego City dam reach; and (8) writing a USGS Water Resources Investigations Report that contains all results.

\section{PROGRESS (October 2001 to June 2002)}

A literature review was conducted. A longitudinal profile was constructed. Previously collected cores and cross section data were examined. Bank stability modeling was begun. Bank erosion measurements were collected in the field.

\section{PLANS (July 2002 to June 2003)}

Finish collecting data and run models. Write report. 


\section{BAD RIVER GEOMORPHOLOGY/STREAMFLOW TRENDS}

\section{COOPERATOR:}

Bad River Tribe

PROJECT CHIEF:

Faith A. Fitzpatrick

\section{LOCATION:}

Bad River Reservation; Ashland County

\section{PROJECT NUMBER:}

WI 23000

\section{PERIOD OF PROJECT:}

May 2001 to September 2002

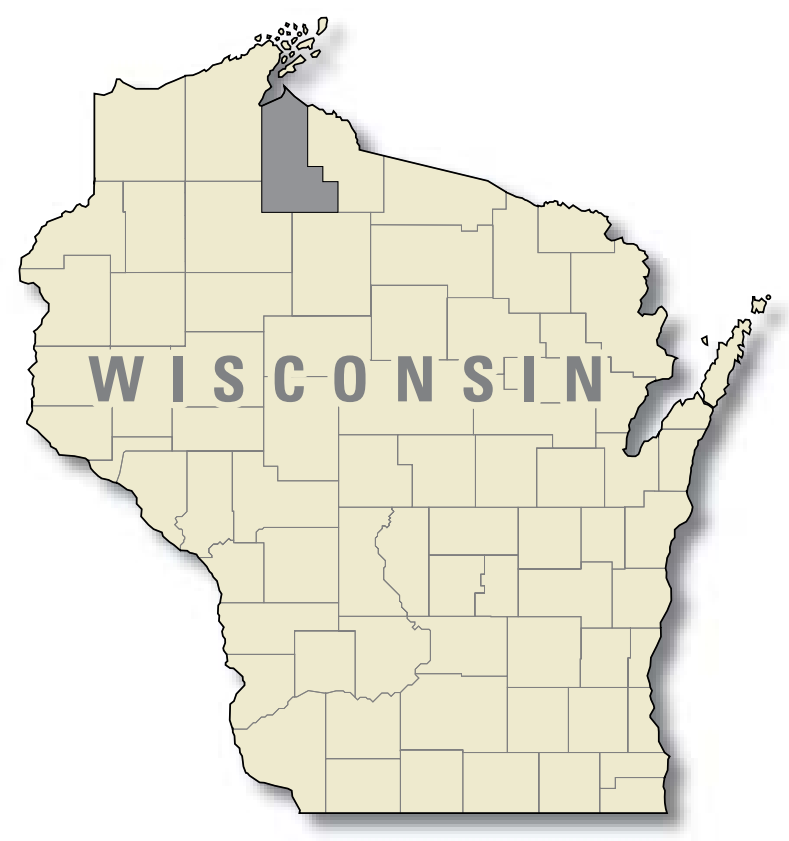

coverages and define watershed characteristics of major subbasins of the Bad River, (2) examine the streamflow record at U.S. Geological Survey gaging station for historical variations, (3) conduct a field reconnaissance trip to identify hot spots of erosion/sedimentation, and (4) conduct a literature search of any publications or studies done on the Bad River Basin related to streamflow, sedimentation, erosion and historical land uses.

\section{PROGRESS (October 2001 to June 2002)}

A field reconnaissance trip was conducted. Literature review, gathering of GIS coverages, and streamflow analysis was begun.

\section{PLANS (July 2002 to June 2003)}

Finish literature review, analysis of streamflow trends, and compilation of GIS coverages for the watershed. Present results to the Bad River tribe personnel.

\section{APPROACH}

The approach involves four aspects for the reconnaissance phase of the study: (1) gather available GIS 



\section{DATABASE APPLICATIONS DEVELOPMIENT TEAM}

\section{Mission}

Provide data organization and distribution services for water resources-related information at local, state, national, and international levels. Targeted organizations include local planning commissions, municipalities, the Wisconsin Department of Natural Resources, USGS, EPA, USAID, and others. An emphasis will be placed on using the Oracle RDBMS system and other Oracle tools for this purpose. Efforts will be made to acquire and develop solutions with the best state-of-the-art technologies available, including high-end data query tools, case tools, WWW-oriented distribution strategies, map serving software, and sophisticated relational database and multi-dimensional OLAP systems.

\section{Team Members}

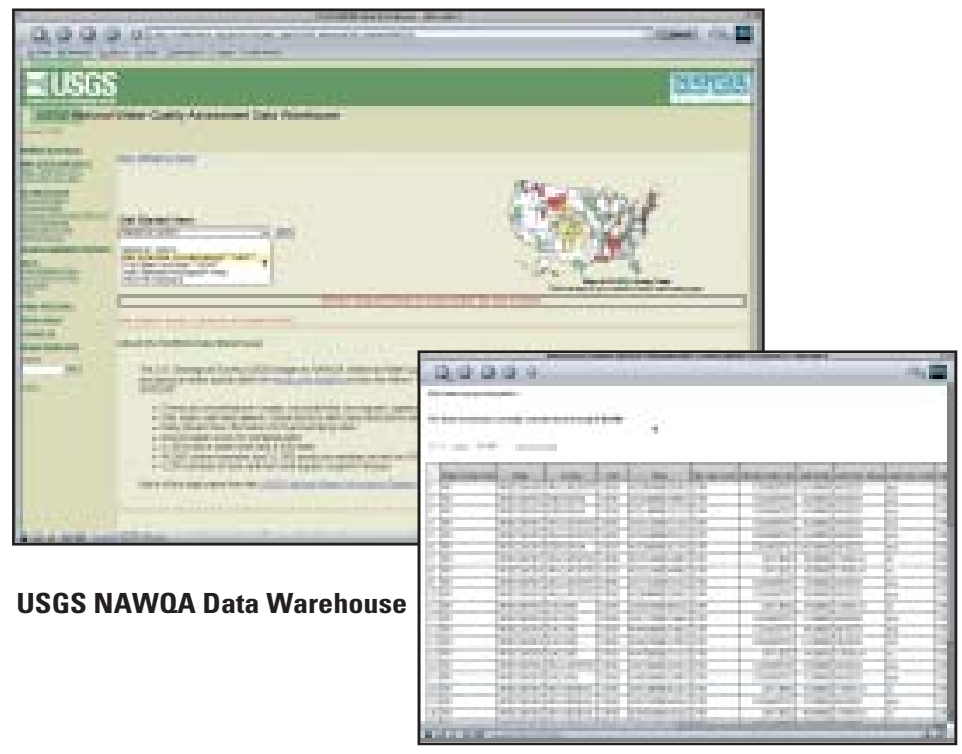

Harry R. House, Hydraulic Engineer

John F. Walker, Research Hydrologist/Engineering

David W. Hall, Hydrologist

Daniel J. Sullivan, Hydrologist

Nathaniel L. Booth, IT Specialist (Systems Analysis)

Morgan A. Schneider, Hydrologist

Judith C. Thomas, Hydrologist

Carolyn J. McCullough, Hydrologist

James R. Statz, Information Technology Specialist

\section{PROJECTS}

Database applications, WI 21000

Wisconsin Department of Natural Resources

biology database, WI 21005 . 


\section{DATABASE APPLICATIONS, WI 21000}

\section{COOPERATORS:}

City of Milwaukee;

U.S. Environmental Protection Agency (USEPA);

U.S. Geological Survey, CAPP and WRD Wisconsin Department of Natural Resources (WDNR)

\section{PROJECT CHIEF:}

Harry R. House

\section{LOCATION:}

United States

PROJECT NUMBER:

WI 21000

PERIOD OF PROJECT:

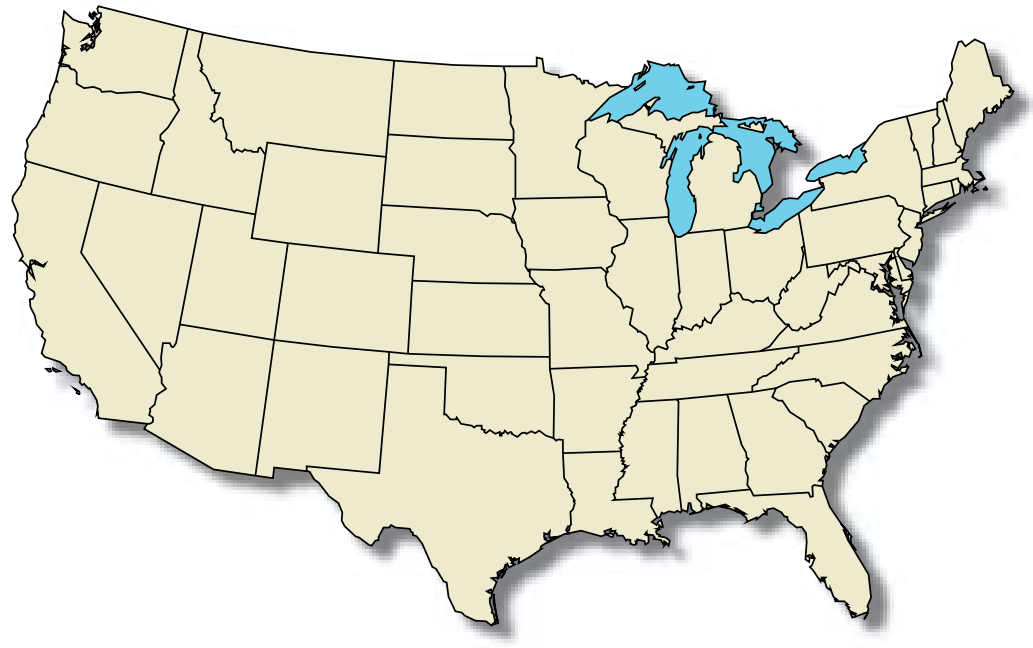

July 1998-Continuing

\section{PROBLEM}

Natural resources agencies are having difficulty organizing, storing, and distributing their information products using their existing resources (staff, hardware, and software).

\section{OBJECTIVE}

The purpose of this project is to provide our cooperators, the USGS, and other agencies with modern alternatives to their existing information technology resources and capabilities. The objective is to provide our customers with access to high-quality data processing methods.

\section{APPROACH}

The Oracle Team in the Wisconsin District is dedicated to the design, development, and deployment of relational database systems geared to address waterresources-related data management problems being faced by our cooperators and other Federal agencies. Systems developed are centered on Oracle Corporation technology at this time. The team provides an alternative resource for these customers to compliment their in-house information technology staff and/or outside consultants.

The Oracle Team applies cutting-edge technology in the resolution of the data management problems, within the limitations of available funding and staff. It is assumed that lower-end technology or approaches are more widely available to our customers already, and that we will provide a more valuable service by providing higher-end systems. The team attempts to maximize the productivity of each developer by using development tools that reduce the need for custom coding, or by simply buying out-of-the-box applications that can be configured and used for agency needs.

\section{PROGRESS (July 2001 to June 2002)}

Eight new servers were purchased to support the increasing resource demands of the unit. Support licensing was renewed for all software, and additional purchases of software for web-enabled graphing was purchased from Visual Numerics Corporation. A 
7-track tape backup system was purchased to further automate the backup procedures for the expanding database network. A full T 1 line was established with a local provider to improve bandwidth to users outside the USGS network. A 10-port $1000 \mathrm{Mb}$ switch was added to improve network transfer speeds between internal team servers. An initial purchase of Redhat Linux was made to investigate the feasibility of putting Oracle middle tier and database tier software on existing Intel hardware, to improve stability, performance, and availability of systems to run newer versions of Oracle software. A large number of publicity articles and bulletins came out describing the teams activities with various IT products. A presentation was made at Oracle Open World describing the teams work on the NAWQA Data Warehouse.

The USGS Products Warehouse (subproject 21002) continued development, and is available for general use in the spring of 2002.

The Milwaukee Beach Health project (subproject 21003) with the City of Milwaukee was refunded, and is available for use by the public and internal users again.

A new geospatial-mapping interface was created for the NAWQA Data Warehouse (subproject 21004) in MapInfo java extreme. New data were entered into the system from the legacy sources.

The WDNR biological database (subproject 21005) added a module for tracking fish propagation information. Additional discoverer reports were created, and the existing forms were improved in response to user requests.

A visit to Russia to evaluate the potential for complimenting the team with selected Russian hydrologist/programmers was conducted in April 2002.

\section{PLANS (July 2002 to June 2003)}

It is expected that there will be additional purchases of servers to further enhance our hardware infrastructure. If an initial test of Redhat Linux is successful, there will likely be a whole-scale conversion to Linux on most servers in the summer/fall of 2002.

Is is anticipated that all current projects except 21003 will be refunded in the next period, and in some cases, at reduced levels in reaction to federal and state cutbacks. Project development activities are expected to make up the difference, if it occurs. In particular, a pilot for an NWIS internal data warehouse, and a Gateway to the Earth geospatial web search engine may prove to be the most likely candidates in this regard.

The productivity of the Russian collaboration will be evaluated, and if deemed successful, it is likely that program will be continued and/or expanded in the future.

Subproject 21002: we will continue gathering and loading citation data in cooperation with USGS Libraries. Internal testing and continued development of the web interface. Testing will begin with a small group and expand with each iteration. Comparisons will be made of completeness of data set with USGS Information Services data sets. We will be working on interfacing with USGS Information Services to provide ordering and pricing information for the products available. We plan to go into production sometime this summer with national publication citation information. In addition, we will create a multi-media database storage and deployment system associated with the data warehouse. The goal is to have the site act as the central repository for WRD for that type of information.

Subproject 21003: We will begin preparation and updating a site for 2002 swimming season. We expect to migrate the site into the newest version of Oracle Portal.

Subproject 21004: There are plans to develop a web-based graphing interface to produce constituent occurrence tables real-time. This would save NAWQA staff weeks of effort in producing these graphics for the 1997 Summary Reports. A re-working of aggregation plans to be done this period to accommodate new NWIS 4.1 structure. Also, there are plans to continue system documentation of all the NAWQA Data Warehouse data and application systems.

Subproject 21005: It is likely that substantial budget cuts at WDNR in FY 2003 will negatively influence the scope of project maintenance and development. While the FY 2003 funding problems have not improved since the last review period, there is much more satisfaction this review period with the performance of the Biology database among DNR management and staff since the $\mathrm{T} 1$ line was installed and the new Fish Propagation Database was successfully rolled out. This new user satisfaction should at least build some support within DNR for the continued operation and funding of the Biology Database project during FY 2003.

Loading of the Ed Emmons/Don Fago dataset of fish and habitat data will be ongoing until completion.

Major revision of all the main database forms and reports is currently scheduled to consume $100 \%$ of the database development time for March through September 2002. Major changes include incorporation of a new Survey ID number into the database and may also involve converting most existing Designer Forms into more powerful and user-friendly Developer Forms. It has not yet been determined if construction of a new STAR schema for query support will be constructed as part of this major database revision. 


\section{WISCONSIN DEPARTMENT OF NATURAL RESOURCES BIOLOGY DATABASE}

COOPERATOR:
Wisconsin Department of Natural
$\quad$ Resources
PROJECT CHIEF:
David W. Hall
LOCATION:
Statewide
PROJECT NUMBER:
WI 21005
PERIOD OF PROJECT:
January 2000-Continuing

\section{PROBLEM}

The Wisconsin DNR Bureau of Fisheries Management and Habitat Protection collects and manages a wide variety of biological data. Data from biological programs were previously managed and stored in multiple databases in a wide variety of formats, making retrieval and analysis of data from the different programs difficult and time consuming. Databases did not exist and were needed to manage the statewide fish propagation program data and also for the statewide habitat assessment programs.

\section{OBJECTIVE}

A single database was needed to unify data from five legacy databases and two new databases. The legacy databases are the Wisconsin Inland Fisheries (Paradox) Database, Wisconsin Fisheries Historical Database, Treaty Database, Master-Fish File Database, and the Macroinvertebrate Database. The two new databases that were developed and were incorporated into the project include the Fish Propagation Database and the Habitat Database.

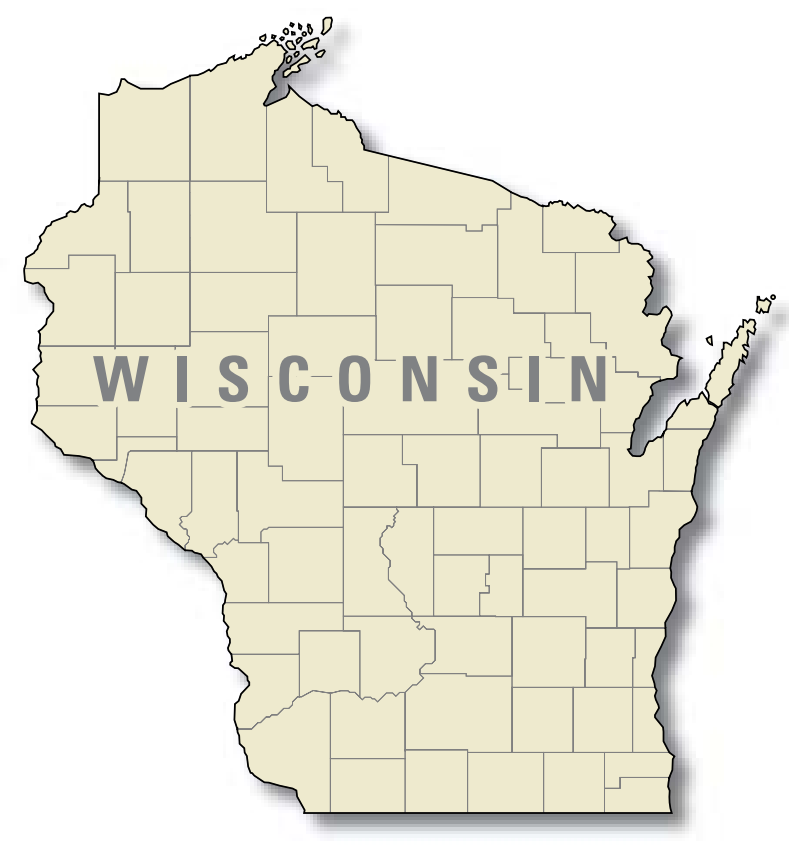

\section{APPROACH}

Initial development of the project was directed toward providing data entry and data reporting capability on the Internet for data from all major field activities. The most widely used field forms for fish, habitat, and macroinvertebrate data were selected for initial development. The database was deployed over the Internet so that geographically-dispersed users across the State could input and access data using electronic forms and reports.

\section{PROGRESS (July 2001 to June 2002)}

The URL for the database website is: http://infotrek.er.usgs.gov/pls/WDNR_BIOLOGY_ WDB/WDNR_BIOLOGY_WDB.home. The database website, forms, and reports have undergone continual refinement in response to user needs in addition to ongoing development of new applications for the database. The first phase of the database was deployed on the Internet on January 1, 2001. Database use increased substantially and has remained high since November 2001 when the USGS Wisconsin District installed a 
direct T-1 line to the Internet which substantially increased database performance. The new propagation component of the database went online in January 2002 and includes data-capture and reporting for processes from stocking-quota development, hatchery production, egg and fish transport, and final stocking. The planned major redesign and refinement of all database applications was undertaken from February through June 2002.

\section{PLANS (July 2002 to June 2003)}

The basic structure of the fish and habitat components of the database will be redesigned from June through September 2002 to link data from related fish and habitat surveys with a comprehensive survey ID. Additional data from legacy datasets will be loaded as time and funding allow. All database hardware and software are continually being upgraded to increase performance and to enhance the utility of the database applications. A feasibility study may be continued to assess the utility of mobile applications and electronic field data-entry forms as a paperless field data-collection system. 



\section{SURFACE WATER TEAM}

\section{Mission}

The surface-water Self-Directed Work Team encompasses a variety of projects that involve monitoring or modeling of the quantity and/or quality of surface-water runoff. The products of these efforts provide critical information to local, state, national and international managers necessary for making decisions regarding laws and regulations, urban development planning and remediation activities. The surface-water team objectives are to: (1) efficiently manage projects from the conception and proposal stage on through management and operation, resulting in informative products, and (2) maintain a sufficient amount of funding and challenging work for the entire team. Through these objectives, it is our intent to continuously evolve with and develop new data collection and analysis techniques, be proficient and respected modelers, plan for future projects, enhance the skills and growth of individual team members, and maintain a positive relationship with our cooperators.

\section{Team Members}

William R. Krug, Hydrologist/Engineering Randy J. Hunt, Research Hydrologist/Geology Jeffrey J. Steuer, Hydrologist/Engineering David J. Gracyzk, Hydrologist/Forestry Gerald L. Goddard, Hydrologic Technician Halward L. Hanson, Hydrologic Technician David E. Housner, Hydrologic Technician Judy A. Horwatich, Hydraulic Engineer Mark A. Corsentino, Student Trainee (Civil Engineering) Timothy L. Hanson, Hydrologic Technician Andrew J. Mumpy, Hydrologic Technician

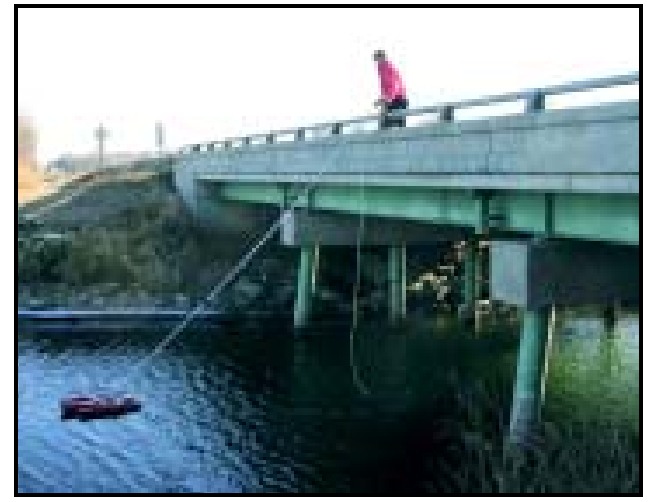

Acoustic Doppler Current Profiler (ADCP) used to measure discharge.

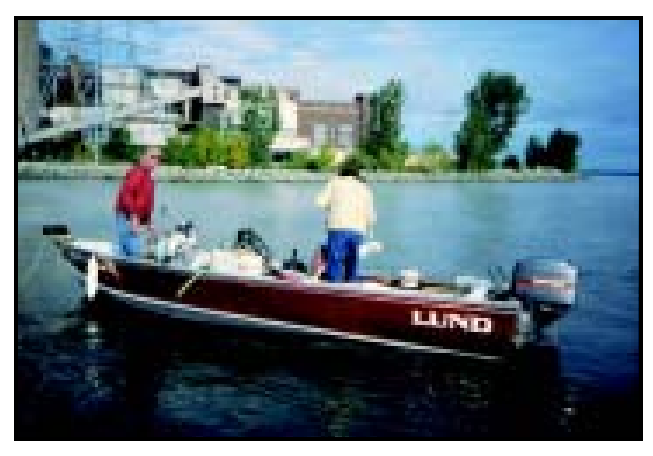

U.S. Geological Survey sampling PCBs on the Fox River at Green Bay, Wisconsin. 


\section{PROJECTS}

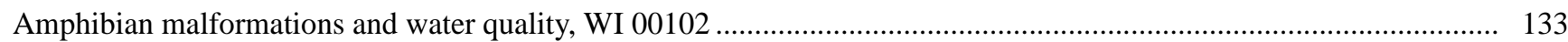

Project collaboration with the Biological Resources Discipline at La Crosse, WI 00103 ............................................. 135

Regional flood-frequency study for urban and rural streams in Wisconsin, WI 10900 …......................................... 137

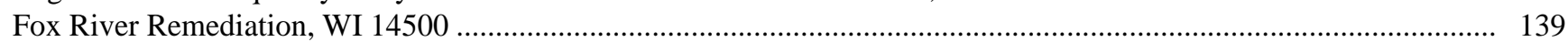

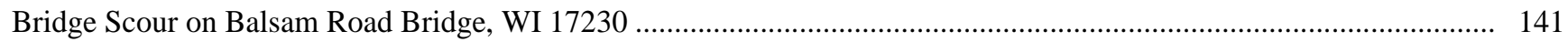

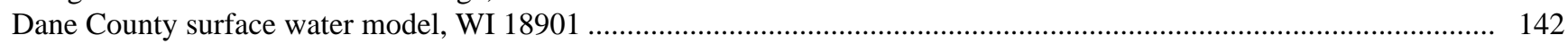

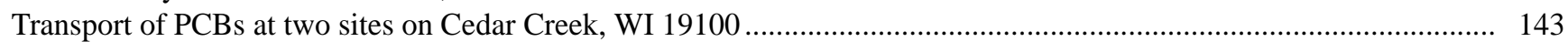

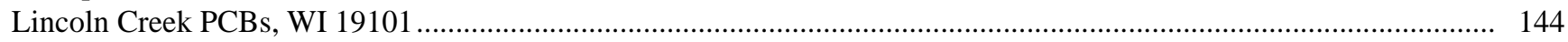

Transport of PCBs at three sites on Pine Creek and Manitowoc River (Hayton Millpond), WI 19102 .......................... 145

Mitigation of future North Fork urbanization impacts on the Pheasant Branch hydrologic system, WI 20202,

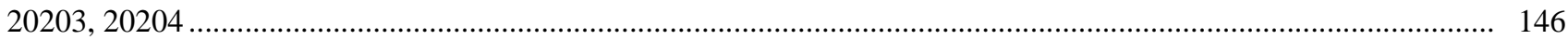

Modeling the effects of the Crandon Mine using the HSPF watershed model, WI 20500 ......................................... 148

Geographic information system (GIS) database development and support of MODFLOW and HSPF modeling

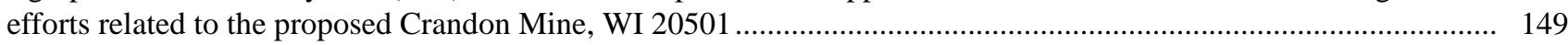

The effect of near-shore development on constituent loading to lakes in Northern Wisconsin, WI 21800...................... 151 


\section{AMPHIBIAN MALFORMATIONS AND WATER QUALITY}

\section{COOPERATORS: \\ U.S. Geological Survey \\ Biological Resources Discipline; \\ Upper Mississippi Environmental \\ Science Center}

\section{PROJECT CHIEF:}

John F. Elder

\section{LOCATION:}

Southern Minnesota

\section{PROJECT NUMBER:}

WI 00102

\section{PERIOD OF PROJECT:}

October 2000 to September 2002

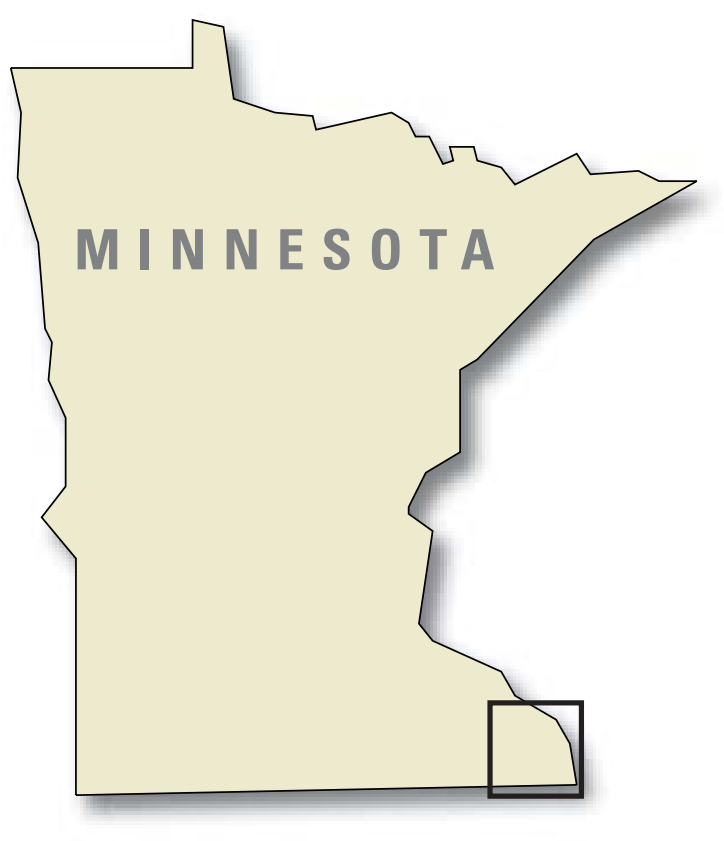

problem are not yet known, despite considerable research into a variety of possible etiologies.

Changes in water quality or hydrologic characteristics seem likely to be associated with amphibian malformations because of extensive exposure of the animals to natural waters and the fact that amphibians breathe at least partly through their skin. However, no research to date has specifically and unambiguously implicated any particular environmental factor as a cause of amphibian malformations. In fact, malformations are almost certainly not attributable to a single cause; they are much more likely to be associated with mixed factors in complex interaction with each other. This project provides water quality data in parallel with amphibian surveys to determine if certain water quality peculiarities exist in ecosystems where amphibian malformations are relatively common. Information about the physical, chemi$\mathrm{cal}$, and ecological characteristics of these ecosystems may lead to identification of some key factors or recent environmental changes that might be associated with developmental changes in the affected amphibian species. 


\section{OBJECTIVE}

To identify and describe any association between amphibian malformations and water quality in pond habitats of southeastern Minnesota. Because the study area is rural-agricultural, emphasis in water-quality analysis is on occurrence of organic compounds that are commonly applied on agricultural fields and might therefore be likely to occur at elevated concentrations in pond waters.

\section{APPROACH}

This study is conducted at rural ponds in Winona and Houston Counties in southeastern Minnesota. The ponds range from less than one acre to a few acres in size. Ponds whose watersheds are fully or partially agricultural fields are matched with similar-size ponds that receive drainage form natural areas. Amphibian collections, for examination of malformations, are accompanied by water sampling for analysis of pesticides and pesticide metabolites. Results for agricultural and natural ponds are compared to assess possible links between occurrence of any compounds or group of compounds and occurrence of amphibian malformations.

\section{PROGRESS (July 2001 to June 2002)}

At all ponds, water samples were collected in spring 2001, and amphibians were collected and exam- ined for malformations. Water samples were chilled and sent immediately to the National Water Quality Laboratory in Lakewood, Colorado for analysis of pesticides and pesticides metabolites. Results showed clear differences between agricultural and natural ponds with respect to occurrence of certain pesticides and pesticide metabolites. Concentrations of atrazine in all agricultural ponds were in excess of 0.3 micrograms per liter, but near or less than 0.1 micrograms per liter in all natural ponds. Some of the agricultural ponds also had elevated concentrations of di-ethyl atrazine, metalochlor, and acetochlor. Very few malformations were found in any of the ponds, however, and no relation could be established between their occurrence and the concentrations of pesticides in the pond water.

\section{PLANS (July 2002 to September 2002)}

Analysis, interpretation, and presentation of data and results from 2001 study. Comparisons of results with other studies. Meet with scientists investigating similar problems in other areas of the country. Additional sampling is not currently planned, although project team is prepared for further data collection upon reports of increased frequency of observations of amphibian malformations.

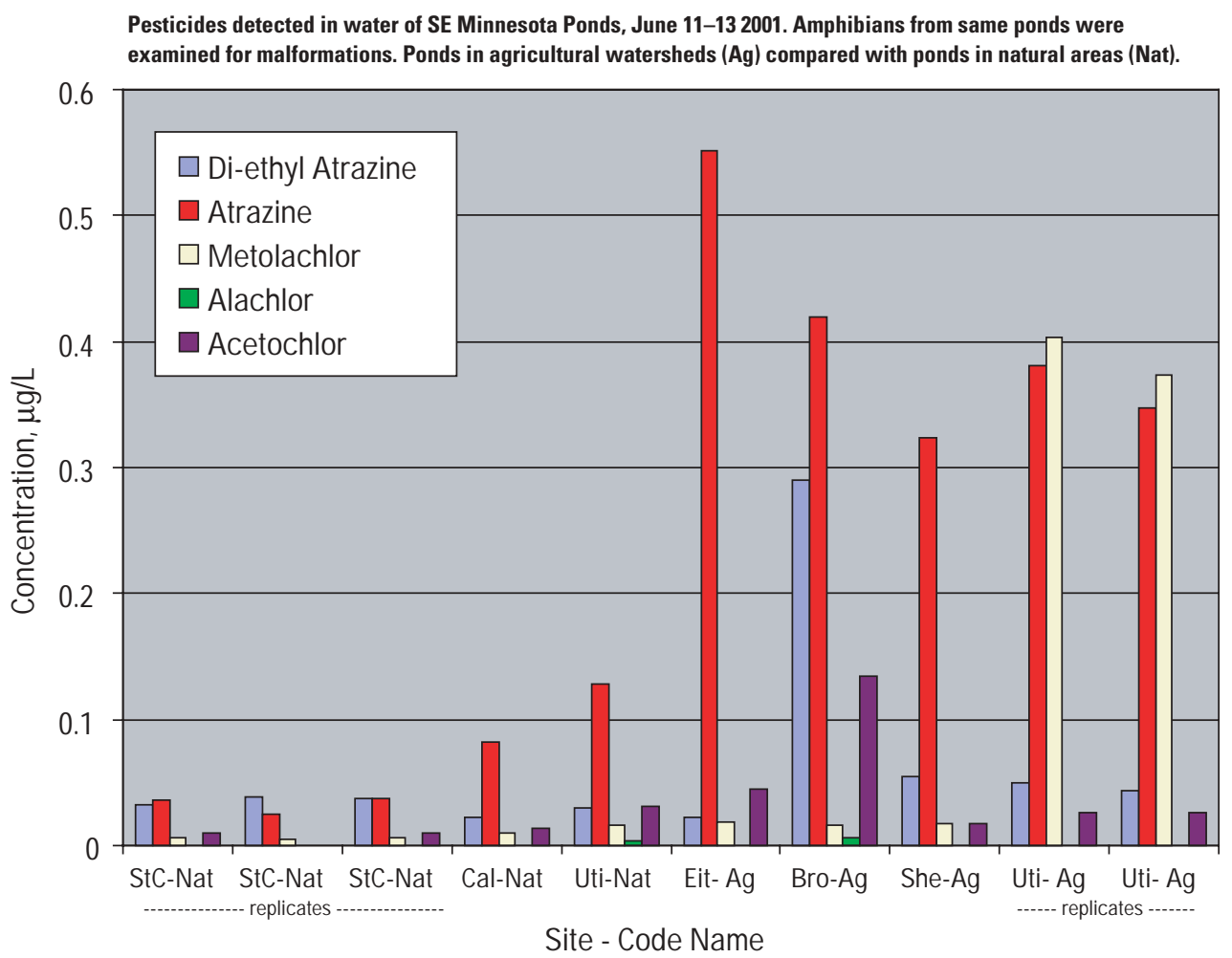




\section{PROJECT COLLABORATION WITH THE BIOLOGICAL RESOURCES DISCIPLINE AT LA CROSSE}

\begin{tabular}{|l|}
\hline COOPERATOR: \\
Biological Resources Discipline, \\
La Crosse, Wisconsin \\
PROJECT CHIEF: \\
Jeffrey J. Steuer \\
LOCATION: \\
La Crosse County \\
PROJECT NUMBER: \\
WI 00103 \\
PERIOD OF PROJECT: \\
October 2000 to September 2002 \\
\hline
\end{tabular}

\section{PROBLEM}

The Mississippi River is one of the world's major river systems in size, habitat diversity, and biological productivity. The Biological Resources Discipline (BRD) Environmental Science Center in La Crosse, Wisconsin, provides scientific understanding, information, and technologies needed to support sound management of biological resources on the Upper Mississippi River. There is a need to bring the BRD expertise into the Wisconsin District (WRD) projects and in return provide hydrologic expertise and experience into the BRD investigations. This project will increase collaboration between the two disciplines.

\section{OBJECTIVE}

The purpose of the project is to enhance BRD and WRD collaboration in investigations such as nitrogen budgets and the resulting biological impacts; urbanization effects on backwater area biota; mercury, PCB, cadmium, and pesticide impacts in zebra mussels; sedimentation patterns and the resulting effects on mussels, paddlefish, and navigation; and hydrologic assis-

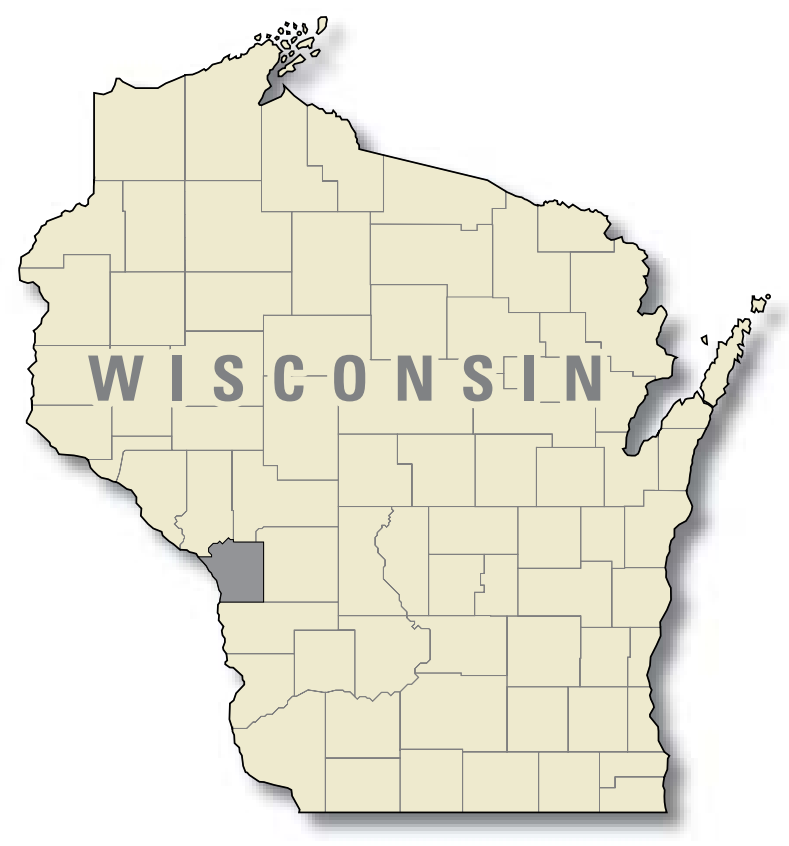

tance in assessing trends in the Upper Mississippi River long-term monitoring program.

\begin{abstract}
APPROACH
From October 2000 through September 2001 one WRD hydrologist worked in the La Crosse BRD office on a half-time basis. This physical relocation of the hydrologist established communication and enhanced collaboration for the inter-discipline personnel. The WRD hydrologist continues to work with the mussel landscape team on a quarter time basis while located in the Middleton Office.
\end{abstract}

\section{PROGRESS (July 2001 to June 2002)}

Much of the present day effort provides the mussel landscape team with hydrologic and hydraulic expertise in the effort to understand why endangered mussel species form their beds in specific locations. These hydraulic efforts have included: conducting bottom roughness and shear calculations in selected Mississippi River pools and an accompanying comparison to historical mussel data; assisting with evaluation of an electronic 
method (RoxAnn) to inventory mussel beds and bottom substrate; and utilizing acoustic Doppler profiles to determine bottom roughness and shear velocity.

An example of newly developing collaborative effort is the Halfway Creek study. Halfway Creek Marsh is situated within the lower reach of Halfway Creek and Sand Lake Coulee Creek watersheds (combined watershed area 28,000 acres) and has an outlet that drains to the Mississippi River Pool. Initial project design will utilize four automated sites to monitor water, sediment, and nutrient fluxes into and out of the natural and constructed sections of Halfway Creek Wet- land. Ultimately the project may evolve into a study of specific nutrient processes that will assist the U.S. Environmental Protection Agency in Total Maximum Daily Load calculations and further understanding in the Mississippi River and Hypoxia problem.

\section{PLANS (July 2002 to September 2002)}

The Middleton WRD hydrologist will continue to work on the mussel landscape team on a quarter time basis. The project is expected to continue beyond September 2002. 


\section{REGIONAL FLOOD-FREQUENCY STUDY FOR URBAN AND RURAL STREAMS IN WISCONSIN}

\begin{tabular}{|l|}
\hline COOPERATORS: \\
City of Fond du Lac; \\
Wisconsin Department of \\
Transportation \\
PROJECT CHIEF: \\
William R. Krug \\
LOCATION: \\
Statewide \\
PROJECT NUMBER: \\
WI 10900 \\
PERIOD OF PROJECT: \\
July 1985-Continuing \\
\hline
\end{tabular}

\section{PROBLEM}

Flood-frequency estimates are required at many sites for bridge and culvert design, as well as for floodplain management and flood-insurance studies. Most sites at which such estimates are required do not have records of flood peaks.

\section{OBJECTIVE}

Objectives are to: (1) operate a State-wide network of crest gages to obtain ongoing information on flood peaks, (2) develop improved regression equations for the State of Wisconsin, and (3) analyze and improve the network of crest-stage gages to obtain better data for developing improved regression equations.

\section{APPROACH}

A network of approximately 90 crest-stage gages will be maintained to gather flood peak information, especially on streams with small drainage areas. The information on annual flood peaks will be used to compute flood-frequency at these sites. Periodically, the

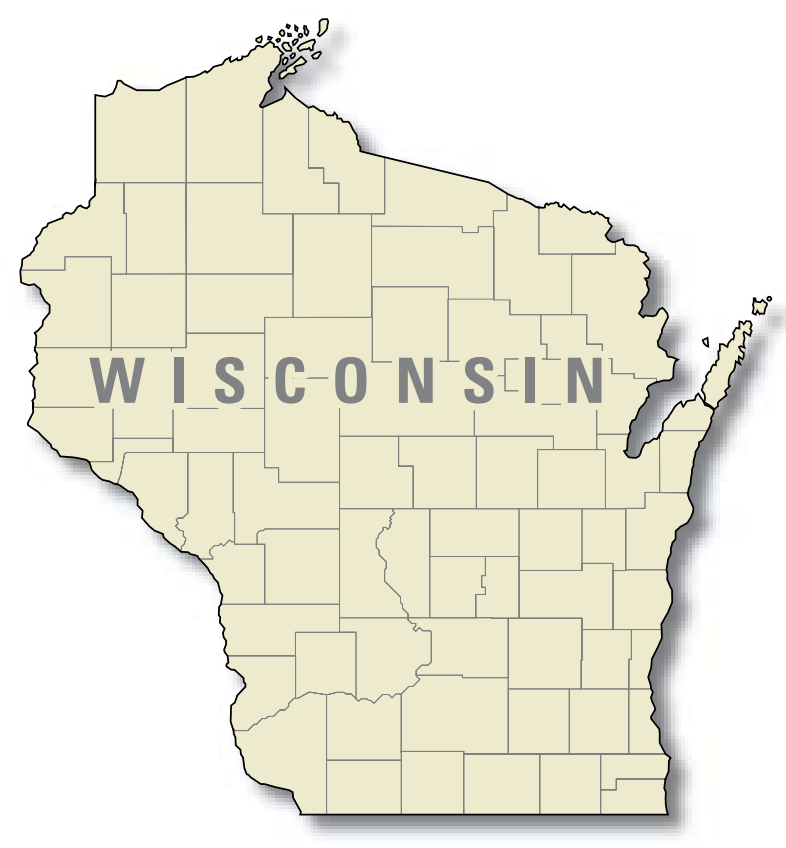

expanded information on flood frequency at streams throughout the state will be used to compute regional flood- frequency equations to estimate flood frequency at ungaged sites.

\section{PROGRESS (July 2001 to June 2002)}

Annual flood peaks were computed and published in the annual data report for 85 crest-stage stations, including 19 of the new stations. Significant effort has been made in measuring flood discharges at crest gages, especially at the newly installed gages, and improving ratings at crest gages. Flood frequency has been recalculated using data through water year 2000.

\section{PLANS (July 2002 to June 2003)}

The crest-stage-gage network will be monitored throughout the year. More new gages will have ratings developed for them as measurements and surveys are available. Significant effort will be made to improve ratings at all the gages. Work will continue on recalculating regression equations for computing flood frequency-leading to publication of a new report. 


\section{REPORTS}

Krug, W.R., 1996, Simulation of temporal changes in rainfallrunoff characteristics, Coon Creek Basin, Wisconsin: Journal of the American Water Resources Association, v. 32 , no. 4 , p. $745-752$.

Krug, W.R., Conger, D.H., and Gebert, W.A., 1992, Floodfrequency characteristics of Wisconsin streams: U.S. Geological Survey Water-Resources Investigations Report 91-4128, 185 p., 2 pls.
Conger, D.H., 1986, Estimating magnitude and frequency of floods for Wisconsin urban streams: U.S. Geological Survey Water-Resources Investigations Report 86-4005, $18 \mathrm{p}$.

Conger, D.H., 1981, Techniques for estimating magnitude and frequency of floods for Wisconsin streams: U.S. Geological Survey Water-Resources Investigations Open-File Report 80-1214, 116 p., 2 pls.

Conger, D.H., 1971, Estimating magnitude and frequency of floods in Wisconsin: U.S. Geological Survey Open-File Report, 200 p. 


\section{FOX RIVER REMEDIATION}

\section{COOPERATOR:}

Wisconsin Department of Natural Resources

\section{PROJECT CHIEF:}

Jeffrey J. Steuer

\section{LOCATIONS:}

Outagamie County

Brown County

PROJECT NUMBER:

WI 14500

PERIOD OF PROJECT:

August 1998 to September 2003

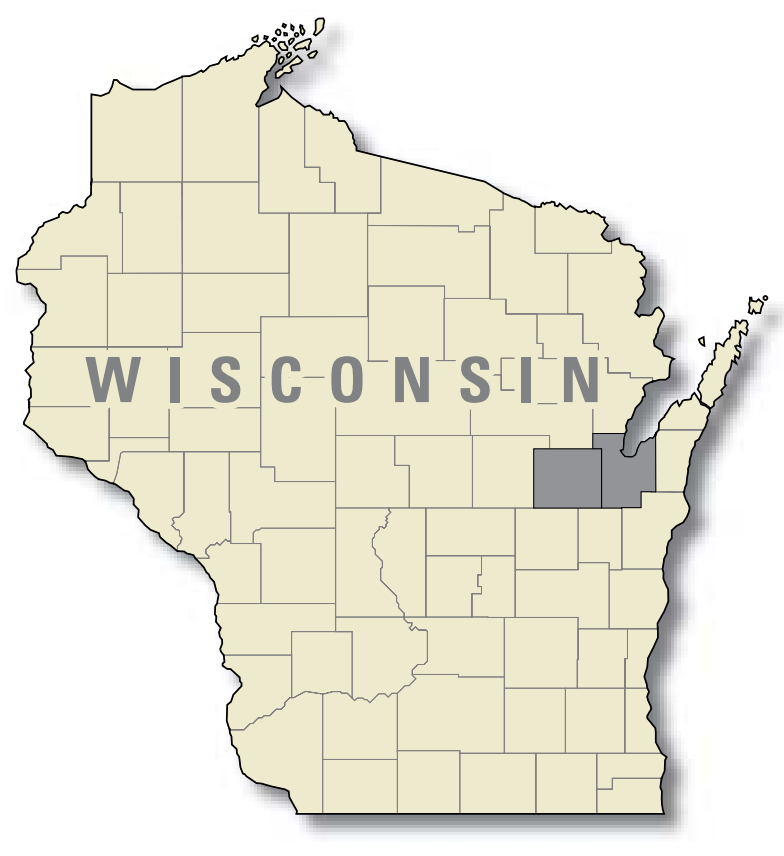

Quality Assurance Project Plan objectives. The objectives are to: (1) evaluate baseline conditions prior to dredging activities, (2) evaluate short-term impacts, including PCB mass fluxes during dredge activities, and (3) evaluate conditions following the completion of dredge-related activities. Objectives for the full-scale remediation have yet to be finalized.

\section{APPROACH}

Pilot-Scale remediation at Deposit "N"-The baseline investigation consisted of water-column samples collected at four upstream locations and four downstream locations prior to the commencement of dredging. Bottom sediment samples were collected from a minimum of 30 locations in Deposit $\mathrm{N}$ and an intermediate zone located between the sediment deposit and the silt-containment barrier.

Evaluation of short-term impact at Deposit "N" includes water-column sampling at four upstream and four downstream locations, dredge slurry samples and continuous-flow monitoring, composite samples of all on-shore processing locations, composite samples of processed solids for landfill disposal, samples of filter media, and treated carriage water samples.

During the pilot-scale remediation efforts, monitoring and sampling will be conducted to meet the project 
Evaluation of long-term impact included collecting sediment core samples from the same locations as the pre-dredge sample sites, and an intermediate zone characterization using visual reconnaissance and sampling.

Pilot-Scale remediation at SMU 56_57-The baseline investigation consisted of water-column samples collected at four upstream locations and five downstream locations prior to the commencement of dredging.

Evaluation of short-term impact SMU 56_57 included water-column sampling at four upstream and five downstream locations, dredge slurry samples with continuous-flow monitoring and composite samples of processed and treated carriage water samples.

\section{PROGRESS (July 2001 to June 2002)}

Deposit "N"-Pre- and post-dredge cores have been collected and processed at 30 locations along with the intermediate zone. Over 90 PCB samples, 800 TSS samples, and over 6,400 water-quality measurements have been collected at the water-column sites. Shoreside (remediation process) samples and slurry flow data have been collected for 29 continuous days. The USGS mercury lab has completed the bottom sediment and remediation process sample analyses. The data analyses is complete and the final report has been written evaluating the water-column transport and the shore-side processes.
SMU 56_57-Over 90 PCB samples, 800 TSS samples, and over 6,400 water-quality measurements have been collected at the water-column sites. Assistance was provided in the slurry sampling and five 80liter effluent samples were processed. The data analyses is complete and the final report has been written evaluating the water-column transport and the overall PCB fluxes.

\section{PLANS (July 2002 to June 2003)}

The USGS will participate in determining the sampling scope and monitoring design in support of the full scale remediation effort. The low level (80-liter; limits of detection of approximately $0.01 \mathrm{ng} / \mathrm{L}$ ) water-column PCB samples along with ancillary data will be collected beginning in June 2002.

\section{REPORTS}

Fox River Remediation Advisory Team, 2000, Evaluation of the effectiveness of remediation dredging: The Fox River Deposit N Demonstration Project November 1998-January 1999: Water Resources Institute Special Report 00-01.

Steuer, J.J., 2000, A mass-balance approach for assessing PCB movement during remediation of a PCB-contaminated deposit on the Fox River, Wisconsin: U.S. Geological Survey Water-Resources Investigations Report 00-4245, 8 p.

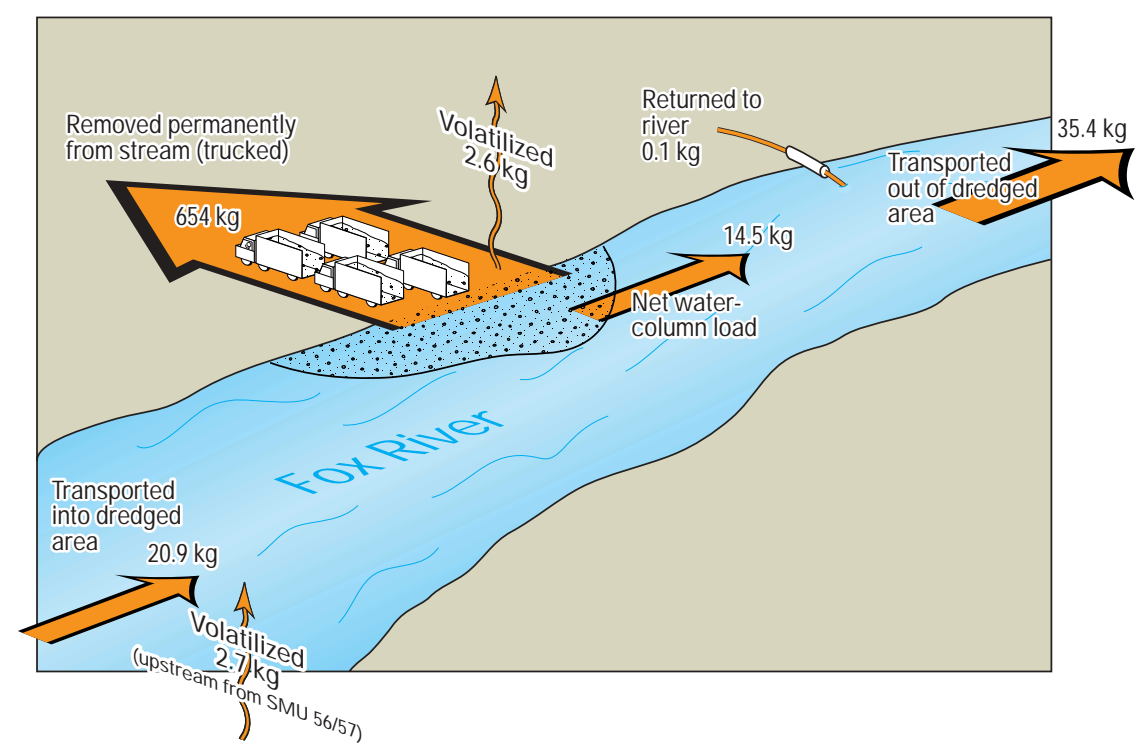

Pathways of polychlorinated biphenyl (PCB) mass (Aroclor 1242) during the September 1-December 15, 1999 remediation at SMU 56/57. Amounts are in kilograms. 


\section{BRIDGE SCOUR ON BALSAM ROAD BRIDGE}

\begin{tabular}{|l|}
\hline COOPERATOR: \\
Marathon County Highway \\
Department \\
PROJECT CHIEF: \\
Peter E. Hughes \\
LOCATION: \\
Marathon County \\
PROJECT NUMBER: \\
WI 17230 \\
PERIOD OF PROJECT: \\
May 1998-Continuing \\
\hline
\end{tabular}

\section{PROBLEM}

Bridge scour has become a topic of nationwide interest in recent years but has not been identified as a serious problem for many bridges in Wisconsin. The Balsam Road bridge over the Big Eau Pleine River in Marathon County is one bridge, however, which has already been severely scoured with pier footings and pilings exposed. The scour hole is concentrated around the bridge location, beginning at approximately 200 feet upstream to approximately 200 feet downstream. An engineering assessment indicates that the 100-year return period discharge could undermine the east abutment and piers 1 and 2 and scour close to pile tip elevations on Pier 3 and the west abutment.

\section{OBJECTIVE}

The objective of this study is to install acoustic transducers to continuously monitor the scour depth on the upstream and downstream sides of the piers at the east side of the bridge. Discharge data from the streamflow gage at Stratford will be used to provide a high flow alert to the USGS and the Marathon County Highway offices to allow closure of the bridge if scour depths increase to dangerous levels.

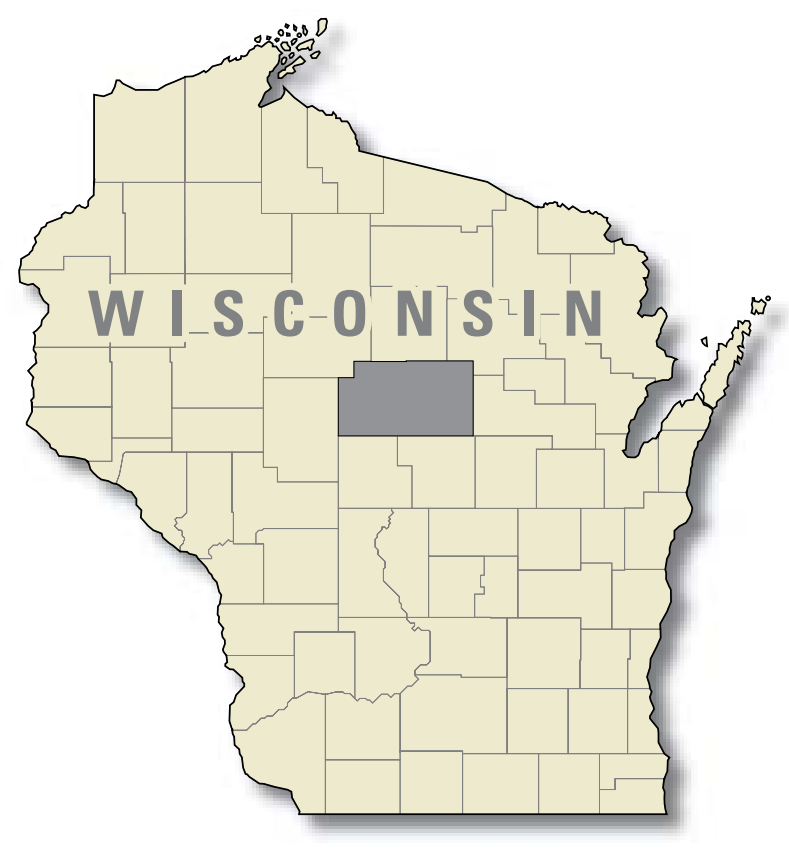

\section{APPROACH}

Acoustic transducers will be attached to the upstream and downstream faces of the most eastern pier on the Balsam Road bridge. The scour depth data will be recorded on a datalogger and telemetered to the USGS office in Middleton, Wisconsin. This information will be automatically uploaded to the World Wide Web home page for the USGS Wisconsin District (http://wi.water.usgs.gov). A voice modem will be installed at the Big Eau Pleine River streamflow gage at Stratford and will be programmed to provide an alert to the Marathon County Highway Department and USGS offices that a flood event is occurring. This alert will provide the opportunity to closely monitor the scour depths to determine whether the bridge should be closed due to hazardous conditions.

\section{PROGRESS (July 2001 to June 2002)}

Scour depth was monitored through September 2001. Data were available on the World Wide Web.

\section{PLANS (July 2002 to June 2003)}

Project has been terminated. 


\section{DANE COUNTY SURFACE WATER MODEL}

\section{COOPERATOR:}

Dane County Regional Planning Commission

PROJECT CHIEF:

William R. Krug

LOCATION:

Dane County

PROJECT NUMBER:

WI 18901

PERIOD OF PROJECT:

April 2001 to March 2002

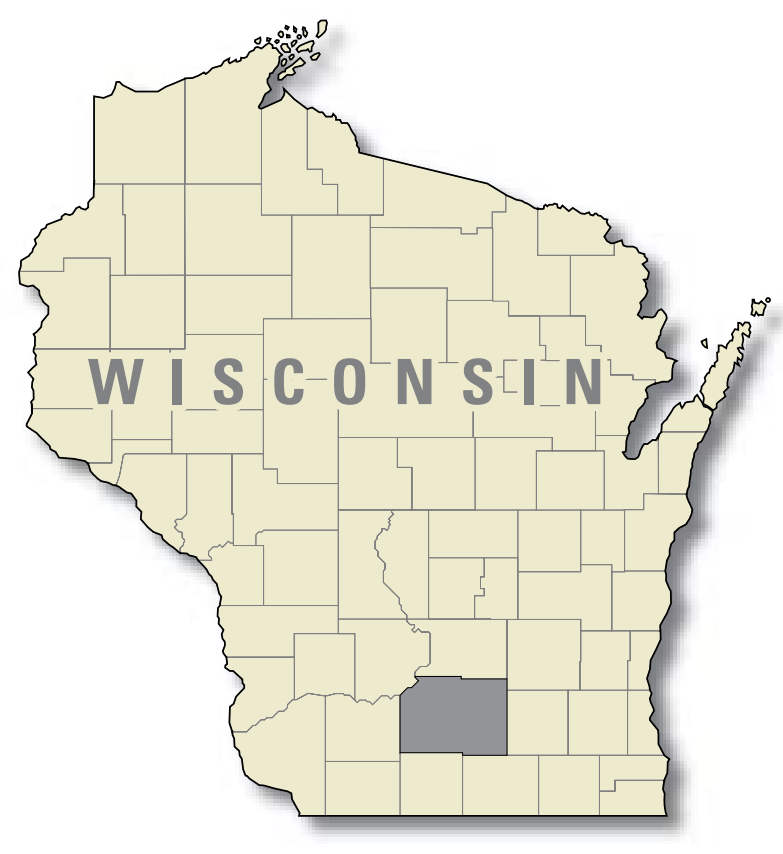

Monona, and Waubesa, South-Central Wisconsin, as Multipurpose Reservoirs to Maintain Dry-Weather Flow" by William Krug (1999), will be modified to reflect current conditions.

Net inflow to be used in the model will be computed from the measured outflow, observed changes in lake stages, and the record of past diversions. Outflow has been measured since September 1930 on the Yahara River near McFarland, Wisconsin. Daily lake stage for most periods of the same years has been measured on Lakes Monona and Mendota. Records of sewage diversion are available from the Madison Metropolitan Sewerage District.

The model will be used to evaluate the effects of various possible alternatives.

\section{PROGRESS (July 2001 to June 2002)}

The model has been adapted to include the latest rating curve for the channel below Lake Waubesa. The input/output formats are being revised to accommodate the additional years of record since the last study.

\section{PLANS}

The final report will be reviewed and published. 


\section{TRANSPORT OF PCBS AT TWO SITES ON CEDAR CREEK}

\begin{tabular}{|l|}
\hline COOPERATOR: \\
Wisconsin Department of Natural \\
$\quad$ Resources \\
PROJECT CHIEF: \\
Jeffrey J. Steuer \\
LOCATION: \\
Ozaukee County \\
PROJECT NUMBER: \\
WI 19100 \\
PERIOD OF PROJECT: \\
April 2000 to September 2002 \\
\hline
\end{tabular}

\section{PROBLEM}

High concentrations of polychlorinated biphenyls (PCBs) have been found in the Cedar Creek bed sediments, water column, and fish tissues. Partial remediation of Cedar Creek (Ruck Impoundment) was completed in 1994. PCB transport trends are needed to assist in future management decisions.

\section{OBJECTIVE}

The objective is to determine PCB loading changes at Columbia Avenue (downstream of the Ruck Impoundment) and Highland Road.

\section{APPROACH}

From August 1994 to August 1995, 24 PCB samples were collected at Columbia Avenue and Highland Road. Total suspended solids, chlorophyll $a$, and discharge data were used in conjunction with the PCB data to establish PCB concentration regression relations.

From December 2000 through October 2001, 24 additional 80-liter PCB samples (along with supporting constituents) will be collected at the two Cedar Creek

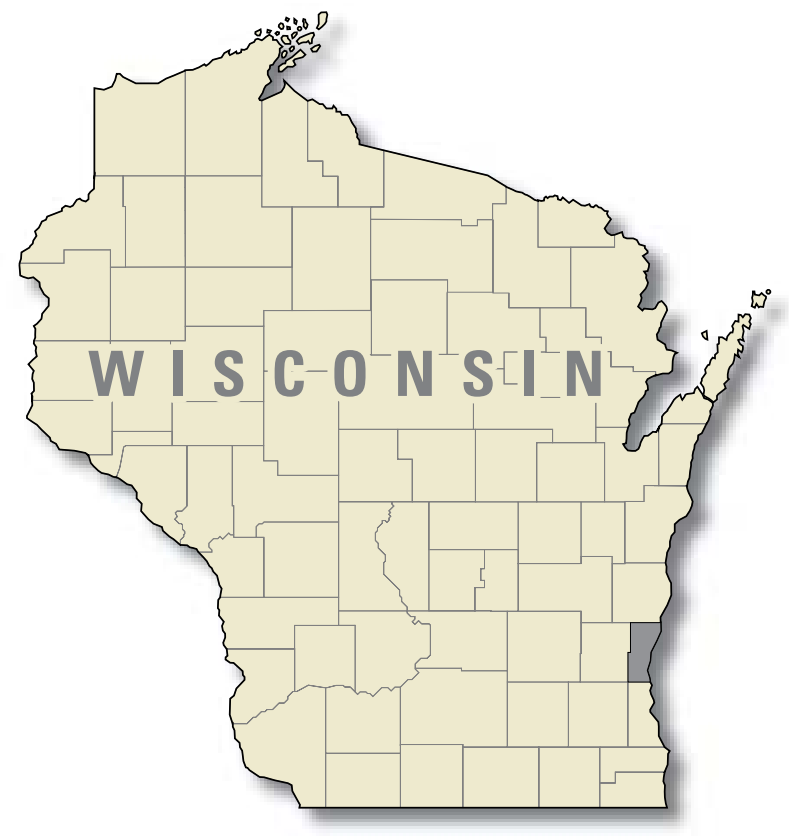

sites. Utilizing these data, residuals from the 1994-95 regression relations will be examined to determine if PCB concentrations have statistically changed over time.

\section{PROGRESS (July 2001 to June 2002)}

Field equipment blanks have been collected; equipment, cleaning and processing procedures have been found to be acceptable. The 24 PCB samples and related constituents have been collected. Laboratory results have been received for 20 of the samples. Immediately downstream of the remediated Ruck Impoundment, several of the samples had no detected congeners in either the dissolved or particulate fractions. Downstream of the Highland Impoundment, total PCB (congener summation) concentrations have ranged from 0.44 to $23.6 \mathrm{ng} / \mathrm{L}$.

\section{PLANS (July 2002 to June 2003)}

In conjunction with the WDNR, this office will conduct data analyses such as comparing previous and current regression residuals in addition to a neural network analysis. 


\section{LINCOLN CREEK PCBs}

\section{COOPERATOR:}

Wisconsin Department of Natural Resources

PROJECT CHIEF:

Peter E. Hughes

\section{LOCATION:}

City of Milwaukee

PROJECT NUMBER:

WI 19101

PERIOD OF PROJECT:

June 2001 to June 2003

\section{PROBLEM}

The Wisconsin Department of Natural Resources is evaluating alternatives for removing PCB contaminated sediments from the Estabrook Impoundment on the Milwaukee River. Lincoln Creek empties into this impoundment and it is important to identify if there are continuing sources of PCBs coming from Lincoln Creek drainages.

\section{OBJECTIVE}

The primary objective of this study is to collect water-column samples during runoff events to quantify the PCB load being transported in Lincoln Creek.

\section{APPROACH}

The USGS will establish a gaging station on Lincoln Creek at 27th Street and install equipment to automatically collect water samples during runoff events. A

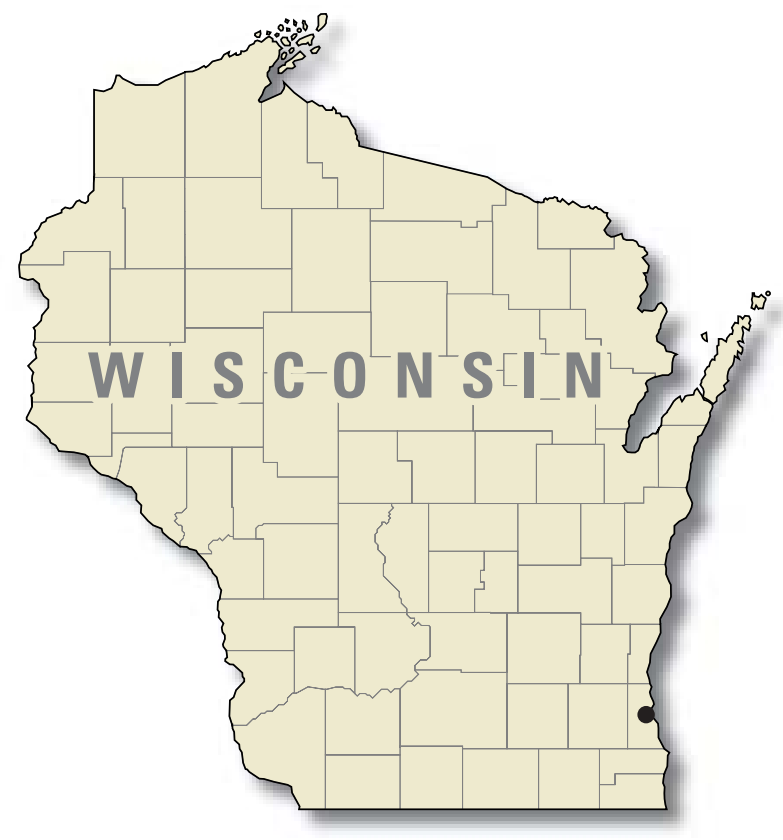

total of 19 event composite samples will be collected and processed for analysis by the Wisconsin State Laboratory of Hygiene for particulate and dissolved PCBs. A total of 110 discrete suspended solids samples will also be analyzed. Streamflow will be continuously monitored and used to compute the PCB and suspended solids loads transported during runoff events.

\section{PROGRESS (June 2001 to June 2002)}

The gaging equipment has been installed and is operational. Sampling of runoff events has started.

\section{PLANS (July 2002 to June 2003)}

Complete collection of the storm samples and submit samples to the lab. Prepare a summary of the data for WDNR. A data report will be prepared which will summarize the storm event loads and flow data collected for this project. 


\section{TRANSPORT OF PCBS AT THREE SITES ON PINE CREEK AND MANITOWOC RIVER (HAYTON MILLPOND)}

\begin{tabular}{|l|}
\hline COOPERATOR: \\
Wisconsin Department of Natural \\
$\quad$ Resources \\
PROJECT CHIEF: \\
Jeffrey J. Steuer \\
LOCATION: \\
Calumet County \\
PROJECT NUMBER: \\
WI 19102 \\
PERIOD OF PROJECT: \\
April 1994 to September 2002 \\
\hline
\end{tabular}

\section{PROBLEM}

High concentrations of polychlorinated biphenyls (PCBs) have been found in the Hayton Millpond and Pine Creek bed sediments, water column, and fish tissues. PCB transport trends are needed to assist in future management and remediation decisions.

\section{OBJECTIVE}

The objective is to determine PCB loading changes at the Hayton Millpond outlet along with PCB loading in reaches of Pine Creek.

\section{APPROACH}

From August 1994 to August 1995, 24 PCB samples were collected at the Hayton Millpond outlet. Total suspended solids, precipitation, chlorophyll $a$, and discharge data were used in conjunction with the PCB data to establish PCB concentration regression relations.

From August 2001 through June 2002, five additional 80-liter PCB samples (along with supporting con-

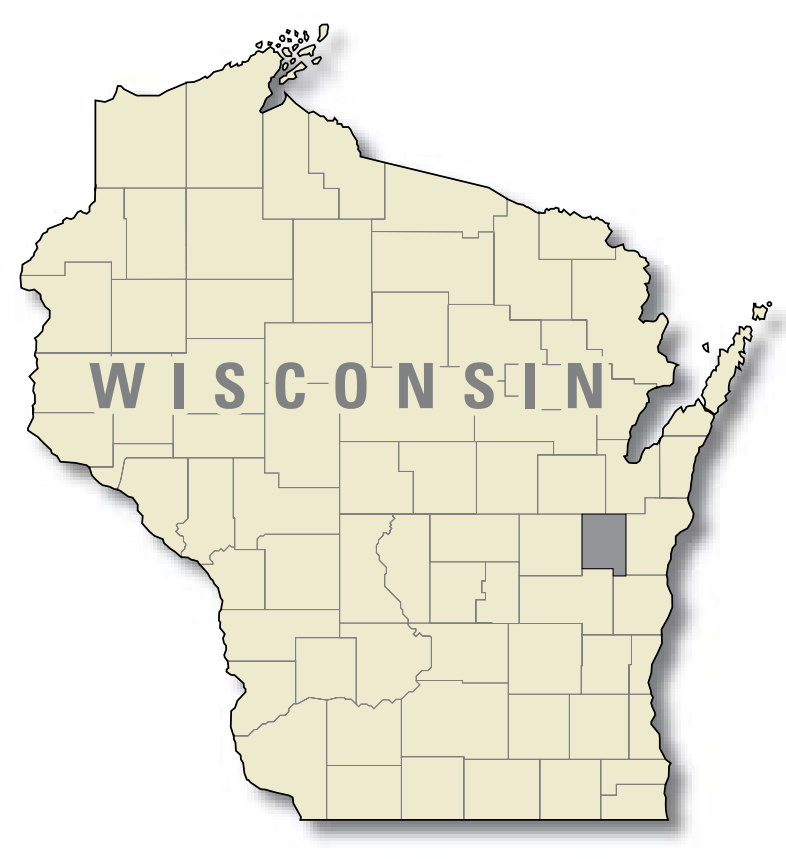

stituents) will be collected at the Millpond outlet along with 10 PCB samples on Pine Creek. Utilizing these data, residuals from the 1993-95 regression relations will be examined to determine if PCB concentrations have statistically changed over time.

\section{PROGRESS (July 2001 to June 2002)}

Field equipment blanks have been collected; equipment, cleaning, and processing procedures have been found to be acceptable. Ten PCB samples and their related constituents have been collected. Laboratory results have been received for three of the samples. Relative loading between the sites may be similar to that observed seven years ago. During August 2001, one of the Pine Creek sites (Quarry Road) had a total PCB (congener summation) concentration of $730 \mathrm{ng} / \mathrm{L}$.

\section{PLANS (July 2002 to September 2003)}

Data analysis will be completed. 


\section{MITIGATION OF FUTURE NORTH FORK URBANIZATION IMPACTS ON THE PHEASANT BRANCH HYDROLOGIC SYSTEM}

\section{COOPERATORS:}

City of Middleton;

Wisconsin Department of Natural

Resources

\section{PROJECT CHIEFS:}

Jeffrey J. Steuer

Randy J. Hunt

\section{LOCATION:}

Dane County

\section{PROJECT NUMBER:}

WI 20202, 20203, 20204

\section{PERIOD OF PROJECT:}

July 1996 to January 2004

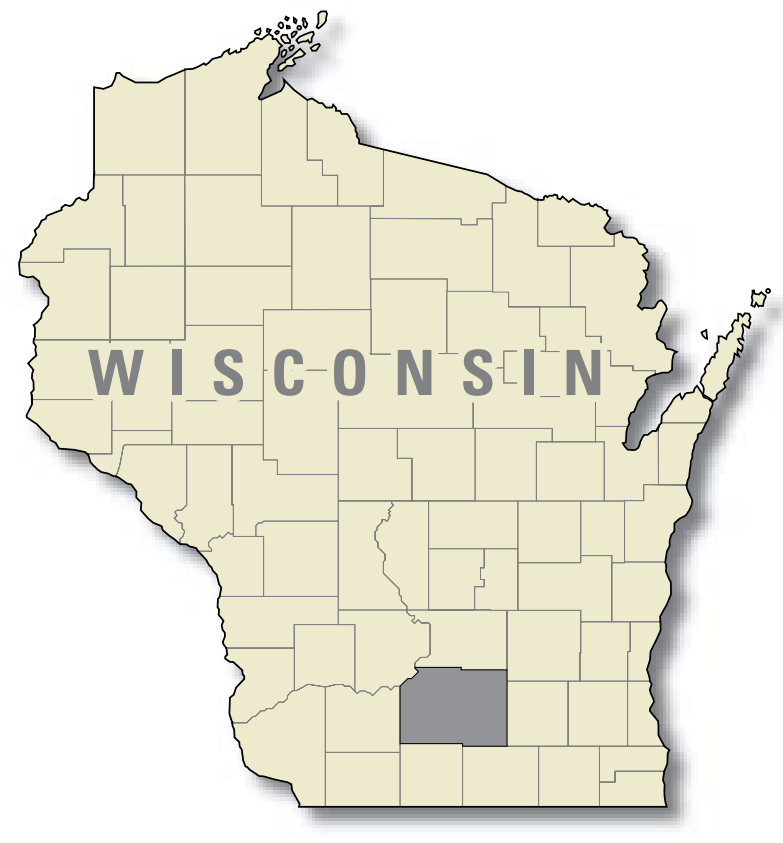

and (4) construct a ground-water model able to address future needs such as siting future water supply.

\section{APPROACH}

The overall approach will combine ground- and surface-water models to locate an effective combination of stormwater treatment or control sites within the North Fork basin which may be developed to produce minimal effects on the Pheasant Branch hydrologic system. The surface-water component will build upon the simulations detailed in "Effects of urbanization on streamflow, sediment loads, and channel morphology in Pheasant Branch Basin near Middleton, Wisconsin" (Krug and Goddard, 1985, WRIR 85-4068). To achieve the objectives of this project, the model will contain a spatial resolution to simulate 1 to 4 developments per square mile (approximately 40 model sub-areas). Significant development has occurred in the South Fork basin since 1981. Two of the areas simulated as not generating runoff in 1981 have developed and presently drain to the South Fork. It will be necessary to update the South Fork basin model to ensure that shifting of the North Fork hydrograph peak (due to runoff controls) will not produce an enhanced peak downstream of the 
confluence (Krug and Goddard, pages 16, 17). The new model efforts will calibrate to recently collected Pheasant Branch discharge and precipitation data collected at Highway 12.

The ground-water component will use a model constructed at a smaller scale than the recently developed Dane County model (Krohelski and others, 2000) to have the appropriate resolution for the stormwater control alternatives. Similar to Krohelski and others (2000), the model will be constructed using MODFLOW (McDonald and Harbaugh, 1988). Recharge results from the surface-water model will be input into the ground-water-flow model to assess the effects of management alternatives on ground-water recharge distribution and magnitude. The model will also calculate the changes in ground-water-derived baseflow in the system for the different alternatives and assess the effectiveness of recharge enhancement scenarios.

In February 2000, the project was expanded when the models were accepted as part of an Environmental Protection Agency (EPA)/National Science Foundation (NSF) research grant. The expanded research will be coordinated by the WDNR and University of Wisconsin-Madison. To further that effort, the surface-water model will be modified to incorporate research findings. The ground-water model will be refined to include additional geologic data and hydrologic features near the Pheasant Branch Marsh.

\section{PROGRESS (July 2001 to June 2002)}

The calibrated PRMS model was updated and verified for the period October 1998 through October 2000 - an interval which included the largest recorded peak flow on Pheasant Branch Creek. Recurrence interval hydrographs for the South Fork Channel were provided to a private consultant in support of the City of Middleton.

Measurements have been made in the Creek to detail individual seepage areas along with several sites that extend downstream to Century Avenue. A flume has been installed downstream of the Frederick Springs area with data displayed on the World Wide Web.

The PRMS model has been nearly converted (90 percent) to the Modular Modeling System to allow inclusion of local infiltration and head flux algorithms.

The Water-Resources Investigation Report, "Use of a watershed modeling approach to assessing the hydrologic effects of urbanization, North Fork Pheasant Branch Basin near Middleton, Wisconsin" and Fact Sheet, "Evaluating the effects of urbanization and landuse planning using ground-water and surface-water models," were published.

Assistance with geophysical logging of a monitoring well near the Springs was given to the Wisconsin Geological and Natural History Survey.

Assistance with drilling of monitoring wells near a study subdivision was given to the Wisconsin Geological and Natural History Survey.

\section{PLANS (July 2002 to June 2003)}

The conversion of the PRMS surface-water model to the Modular Modeling System will be completed and modules for the local infiltration and head flux algorithms will be written.

Support will be given to the larger Pheasant Branch project conducted by the Wisconsin Department of Natural Resources, the University of Wisconsin-Madison, and the Wisconsin Geological and Natural History Survey. The work includes well installation and instrumentation in a study subdivision and chemical and isotope analyses for water samples collected during the study.

\section{REPORTS}

Hunt, R.J., and Steuer, J.J., 2000, Simulation of the recharge area for Frederick Springs, Dane County, Wisconsin: U.S. Geological Survey Water-Resources Investigations Report 00-4172, 33 p.

Hunt, R.J., Steuer, J.J., Mansor, M.T.C., and Bullen, T.D., 2001, Delineating a recharge area for a spring using numerical modeling, Monte Carlo techniques, and geochemical investigation: Ground Water, v. 39, no. 5, p. 702-712.

Steuer, J.J., and Hunt, R.J., 2001, Use of a watershed-modeling approach to assess hydrologic effects of urbanization, North Fork Pheasant Branch Basin near Middleton, Wisconsin: U.S. Geological Survey Water-Resources Investigations Report 01-4113, 49 p.

Hunt, R.J., and Steuer, J.J., 2001, Evaluating the effects of urbanization and land-use planning using ground-water and surface-water models: U.S. Geological Survey Fact Sheet FS-102-01, 4 p. 


\section{MODELING THE EFFECTS OF THE CRANDON MINE USING THE HSPF WATERSHED MODEL}

\section{COOPERATOR: \\ U.S. Environmental Protection Agency \\ PROJECT CHIEF: \\ Jana S. Stewart \\ LOCATION: \\ Forest County \\ PROJECT NUMBER: \\ WI 20500 \\ PERIOD OF PROJECT: \\ January 1997 to September 2002}

\section{PROBLEM}

The Nicolet Minerals Company has proposed construction of a zinc and copper mine near Crandon, Wisconsin. Before any operations can begin, an environmental impact assessment must be written and approved. At present, it is uncertain what specific effects the mine will have on the hydrology and water quality of the streams and lakes in the area.

\section{OBJECTIVE}

The objectives of this project are to: (1) assemble hydrologic, meteorologic, and land-use information for the area near the proposed mine, (2) develop a watershed model for the Swamp Creek basin, and (3) use the model to determine what potential impacts the mine will have on the hydrology of Swamp Creek and nearby lakes.

\section{APPROACH}

Available hydrologic, meteorologic and land-use information will be obtained from the U.S. Geological Survey databases, the Nicolet Minerals Company, the Mole Lake Tribe, the Wisconsin state climatologist, the

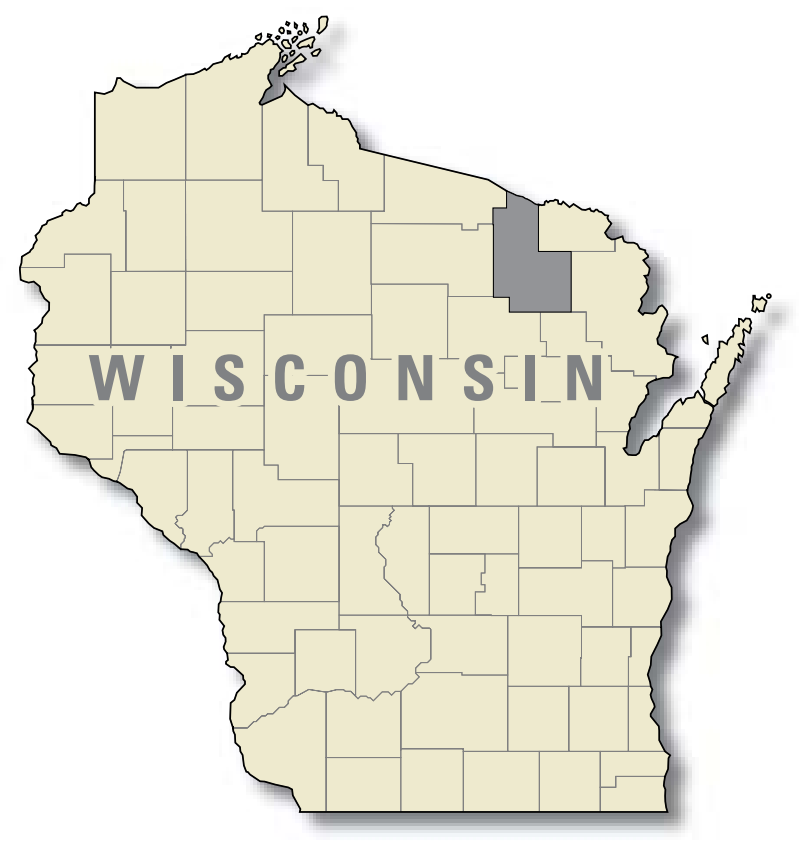

National Climatic Data Center, and the Wisconsin Department of Natural Resources. These data will be used to develop a watershed model for the Swamp Creek Basin using the Hydrologic Simulation Program Fortran (HSPF) watershed model. The model will be calibrated using a subset of data available for Swamp Creek and verified using an independent subset of the data. The model will be adjusted to simulate mine construction, operation, and closure. The output of the model will be used to quantify the effects of the mining operations on the water levels of streams and lakes in the area.

\section{PROGRESS (July 2001 to June 2002)}

Model scenarios are in progress and a report being written.

\section{PLANS (July 2002 to September 2002)}

The calibrated HSPF model will be adjusted to quantify the effects of the mine construction, operation, and closure on the water levels of streams and lakes in the area. The report will be finalized and final GIS layers will be documented. Meetings will be conducted to present final results. 


\section{GEOGRAPHIC INFORMATION SYSTEM (GIS) DATABASE DEVELOPMENT AND SUPPORT OF MODFLOW AND HSPF MODELING EFFORTS RELATED TO THE PROPOSED CRANDON MINE}

\section{COOPERATOR:}

U.S. Army Corps of Engineers

PROJECT CHIEF:

Jana S. Stewart

LOCATION:

Forest County

PROJECT NUMBER:

WI 20501

PERIOD OF PROJECT:

October 1998 to September 2002

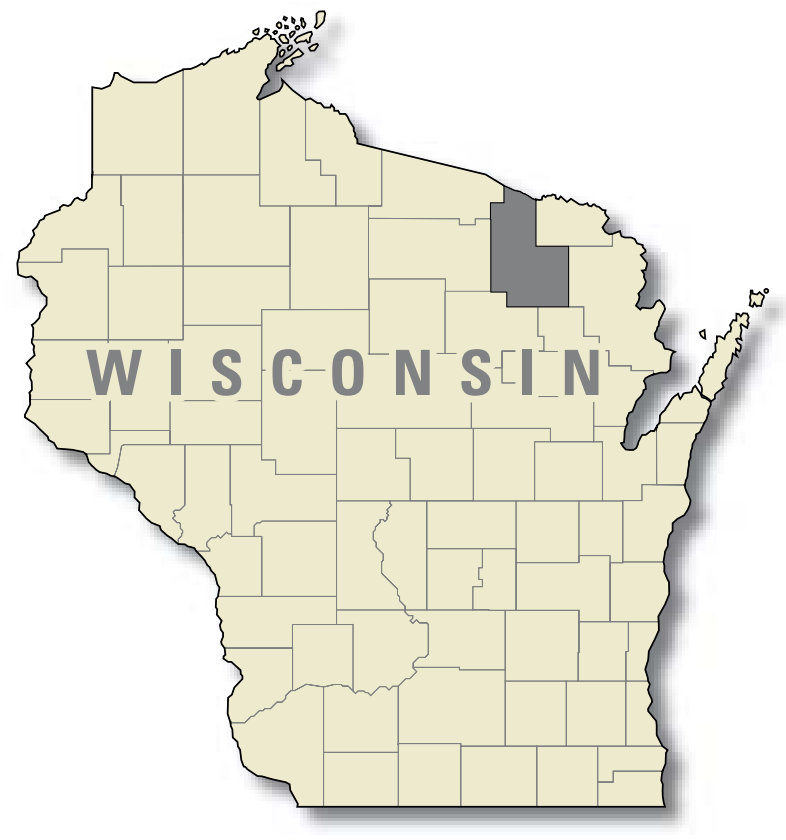

\section{OBJECTIVE}

The objectives of this project are to (1) coordinate GIS data acquisition and related communication in support of modeling and impact assessment, as directed by the U.S. Army Corp of Engineers (USACE), (2) conduct GIS analyses and provide displays related to the USACE third party MODFLOW modeling contractor effort, as needed and as directed by the USACE and USACE-Waterways Experiment Station, and (3) review GIS analyses and displays related to third party Environmental Impact Statement contractor effort, as needed and directed by the USACE.

\section{APPROACH}

Spatial data layers will be acquired and developed as needed to assist in both surface- and ground-water modeling efforts and in support of impact assessment. Map figures and spatial data layers will be prepared using ARC/INFO and ArcView GIS software. Existing spatial data layers will be acquired from outside 
resources, including Wisconsin Department of Natural Resources, Great Lakes Indian Fish and Wildlife Commission, and Nicolet Minerals Company, if available. Other data layers will be developed and analyses conducted as needed.

\section{PROGRESS (July 2001 to June 2002)}

The original scope of work for this project was rewritten as a result of the USACE FEMWATER modeling effort being dropped in place of a third party contractor MODFLOW modeling effort. Spatial data layers were acquired and map figures prepared as needed by the USACE, and the EIS contractors. A list of available data layers was prepared for the USACE and the EIS contractor.

\section{PLANS (July 2002 to September 2002)}

Spatial data layers will be acquired, GIS analyses conducted, and map figures prepared, as needed by the USACE or the MODFLOW or EIS contractors. Review of GIS analyses and map figures will be conducted as requested by the USACE. 


\section{THE EFFECT OF NEAR-SHORE DEVELOPMENT ON CONSTITUENT LOADING TO LAKES IN NORTHERN WISCONSIN}

\author{
COOPERATOR: \\ Wisconsin Department of Natural \\ Resources \\ PROJECT CHIEFS: \\ David J. Graczyk \\ Randy J. Hunt

\section{LOCATION:} \\ Vilas and Forest Counties \\ PROJECT NUMBER: \\ WI 21800 \\ PERIOD OF PROJECT: \\ October 1999 to September 2003
}

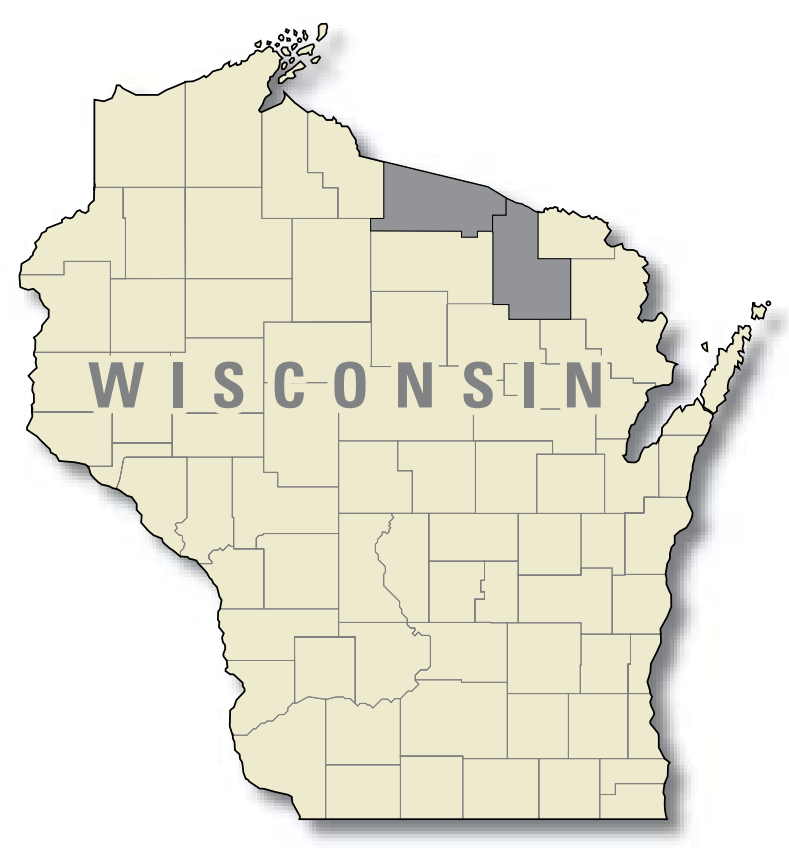

runoff and ground water that flows into a lake from developed and undeveloped lands.

\section{APPROACH}

Effects of shoreline development on water and nutrient loading will be assessed using a paired approach. The comparison will focus on developed and undeveloped sites on four lakes in Vilas and Forest Counties in northern Wisconsin. Developed sites may include runoff from lawns, driveways, sidewalks, and roofs; undeveloped sites consist of mostly immature woods having woody and non-woody vegetation and relatively undisturbed ground. Both surface-water runoff and ground-water components will be characterized where appropriate.

Sites were divided into those where the lakes have ground-water inflow and those that do not. Those that had ground-water inflow will be instrumented to characterize the ground- and surface-water components. Sites with ground-water flow away from the lake will be instrumented to characterize surface-water components only. Each site will be surveyed and a detailed map will be prepared to determine the areas that contribute to surface runoff. 
A tipping bucket rain gage will be installed at each site. Precipitation will be measured during the nonfreezing portion of the year. Precipitation from a nearby National Weather Service gage will be used during freezing periods.

Surface-water runoff will be measured by using two types of monitors depending on the site. An automatic collection monitor will be installed at four sites. A passive collection monitor will be installed at two sites. The quality of surface water will be determined from analyses of the runoff collected by both automated and non-automated systems.

Ground-water flow will be monitored by the installation of piezometer nests. The nests will be distributed along the topographic gradient. The most down-gradient nest will be installed adjacent to the lakeshore. The quality of ground water will be determined from a subset of water table wells and piezometers located at the nest sites. In addition, the quality of ground water that discharges to the lake will be characterized using seepage meters and pore-water diffusion equilibrators. All surface- and ground-water samples will be analyzed for total dissolved phosphorus, total phosphorus, ammonia nitrogen, nitrate and nitrite nitrogen, and total Kjeldahl nitrogen. Approximately 7 surface-water samples per site will be collected, and 5-10 ground-water samples will be collected. The Wisconsin State Laboratory of Hygiene will analyze all samples.

\section{PROGRESS (July 2001 to June 2002)}

Samples were collected and analyzed at selected ground-water wells and at the surface-water data-collection sites. There were 76 samples collected at the four lawn sites and 67 samples collected at the seven woods sites. The median surface runoff in inches from the woods catchments was an order of magnitude less than the median surface runoff from the lawn catch- ments. All surface-water samples from the lawn and the woods were composited; the median woods concentration for ammonia nitrogen, Kjeldahl nitrogen, total phosphorus, and dissolved total phosphorus was greater than the median lawn concentrations. The only median lawn concentration that was greater than woods median concentration was nitrate plus nitrite nitrogen. A nonparametric Wilcoxon rank-sum test determined that composite lawn median concentrations were statistically significantly different from the woods median concentrations. Although concentrations for most constituents were greater in the woods samples, the loads from the woods were lower than the lawns because of greater runoff volumes generated from the lawn catchments. There was a strong pattern of the lawn yields exceeding the woods median yields (within and between sites). This is due to more runoff from the lawns than from the woods sites. The ground-water system is an important ground-water pathway for nutrient transport. The ground-water yields from lawns are approximately three to four times greater contributors of nitrate plus nitrite and total phosphorus to the groundwater system than the woods site.

\section{PLANS (July 2002 to June 2003)}

A final report is being prepared that will summarize all surface-water and ground-water data. The report will also summarize all loadings and yields to the lake from the different land uses. Final report will be published. The next data-collection phase will begin. Data-collection sites will be found and a buffer demonstration project will begin. This project will focus on the hydrology and determine how water moves across a lawn and then to a buffer and if this water eventually makes it to the lake. The study will use a rainfall simulator and inert tracers to determine how and the volumes of water that flow through the buffer.
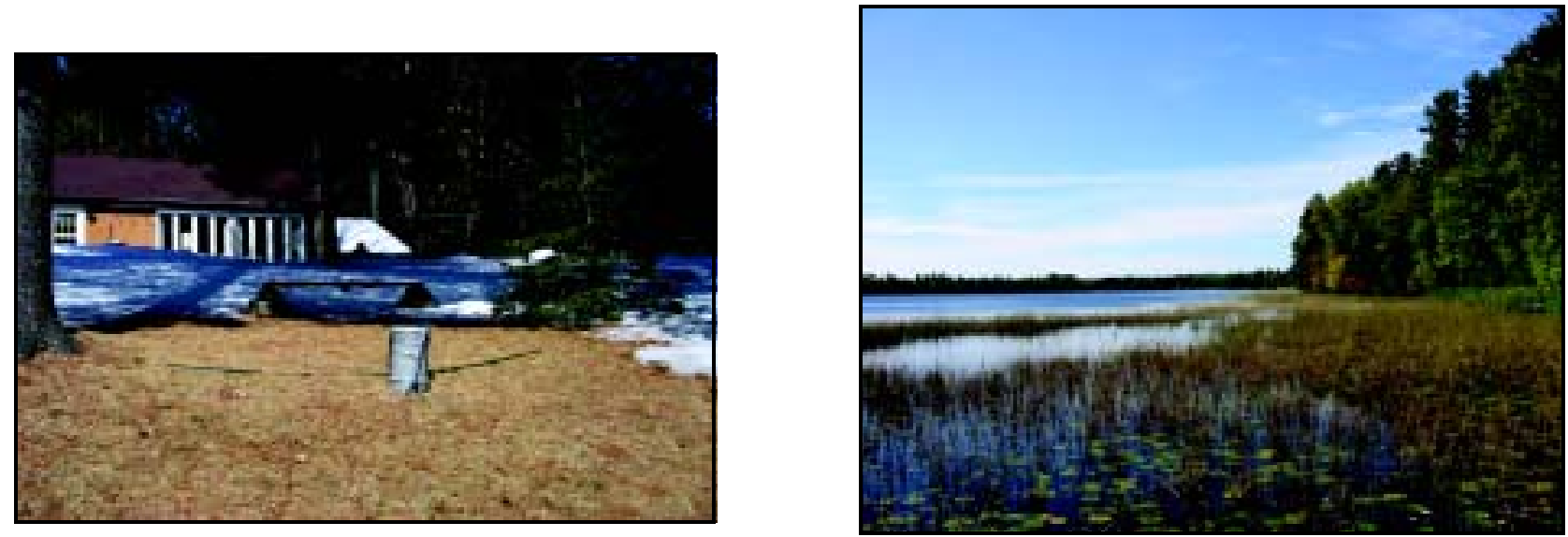


\section{URBAN NONPOINT TEAM}

\section{Mission}

The urban monitoring Self-Directed Work Team (SDWT) provides information critical to cooperators to make informed urban water resource decisions. Team objectives are to efficiently manage projects from conception and proposal stage through the operation and management phases, resulting in thoughtful and timely products whether they be data requests, data summaries or final reports. Through these objectives it is our intent to continuously improve site installation, technical approach, data collection coordination, financial management and report production of urban studies. We will strive to maintain a positive cooperator relationship and to enhance the skills and growth of individual team members.

\section{Team Members}

William R. Selbig, Hydrologist

Robert J. Waschbusch, Hydrologist

David W. Owens, Hydraulic Engineer

Steven R. Corsi, Hydrologist

Troy D. Rutter, Hydrologic Technician

Judy A. Horwatich, Hydraulic Engineer

Joel A. Brieske, Hydrologic Technician
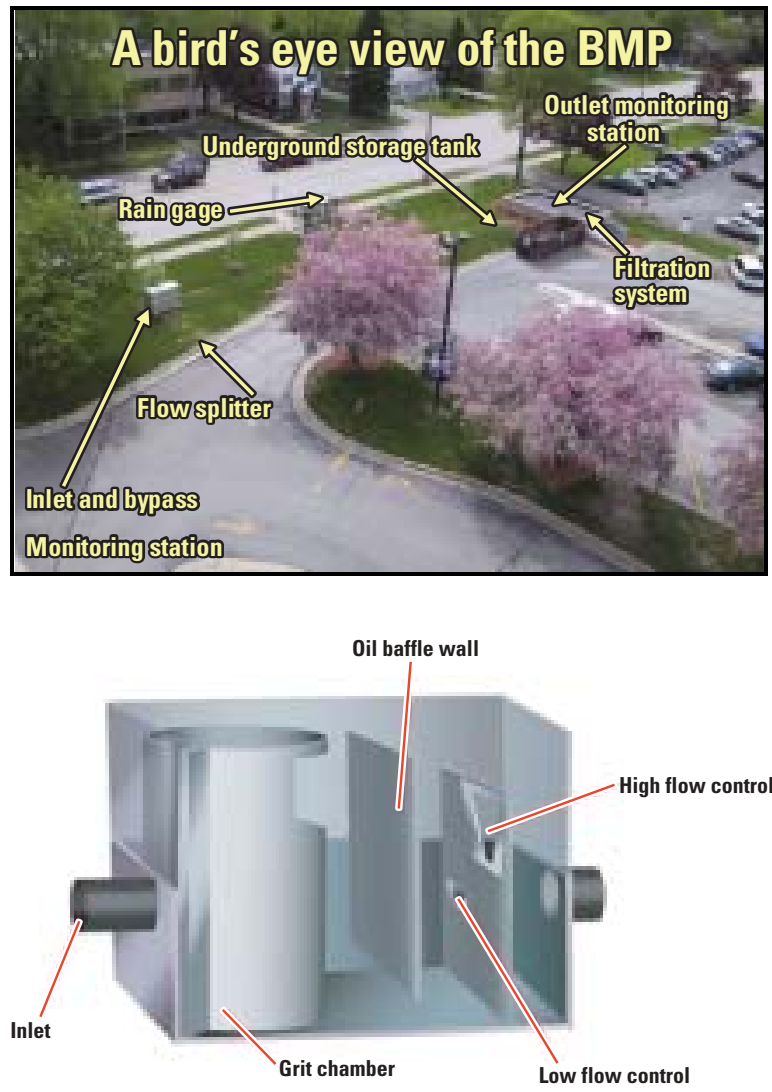

Vortechs ${ }^{\mathrm{TM}}$ System by Vortechnics. 


\section{PROJECTS}

Verification of treatment performance of the Vortechnics and stormwater management filter, WI 17207....................... 155

Verification of pressurized stormwater filtration system at St. Mary's Hospital, WI 17208 ........................................ 157

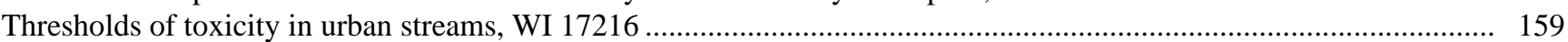

Calibration of the source loading and management model (SLAMM), WI 17219 …................................................. 161

Evaluating improved street sweeping for enhancing water quality in highway runoff in Milwaukee, WI 17231............. 163

Evaluation of the effectiveness of low-impact development practices, WI 17233 ..................................................... 165

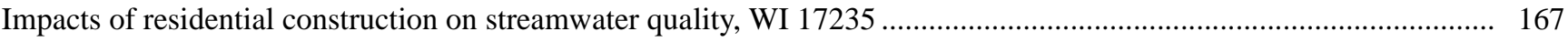

Evaluation of street sweeping as a water-quality management tool in residential basins in Madison, WI 17237............. 169

Educational BMP evaluation program for two basins in the city of Milwaukee, WI 17241 ........................................ 171

Monitoring and evaluation of the impacts of aircraft and runway deicers on the Kinnickinnic River surface-water

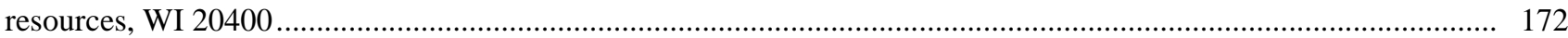

Sources of cryptosporidium in watersheds, WI 21600.................................................................................. 174

Occurrence and variability of pathogens in Wisconsin's urban streams, WI 22300 .................................................... 176

Collection of real-time and pathogen data at recreational beaches in Madison, WI 22800 ......................................... 178 


\section{VERIFICATION OF TREATMENT PERFORMANCE OF THE VORTECHNICS AND STORMWATER MANAGEMENT FILTER}

\section{COOPERATOR:}

Wisconsin Department of Transportation

\section{PROJECT CHIEFS:}

Judy A. Horwatich

David W. Owens

\section{LOCATION:}

City of Milwaukee

PROJECT NUMBER:

WI 17207

\section{PERIOD OF PROJECT:}

October 2000 to September 2003

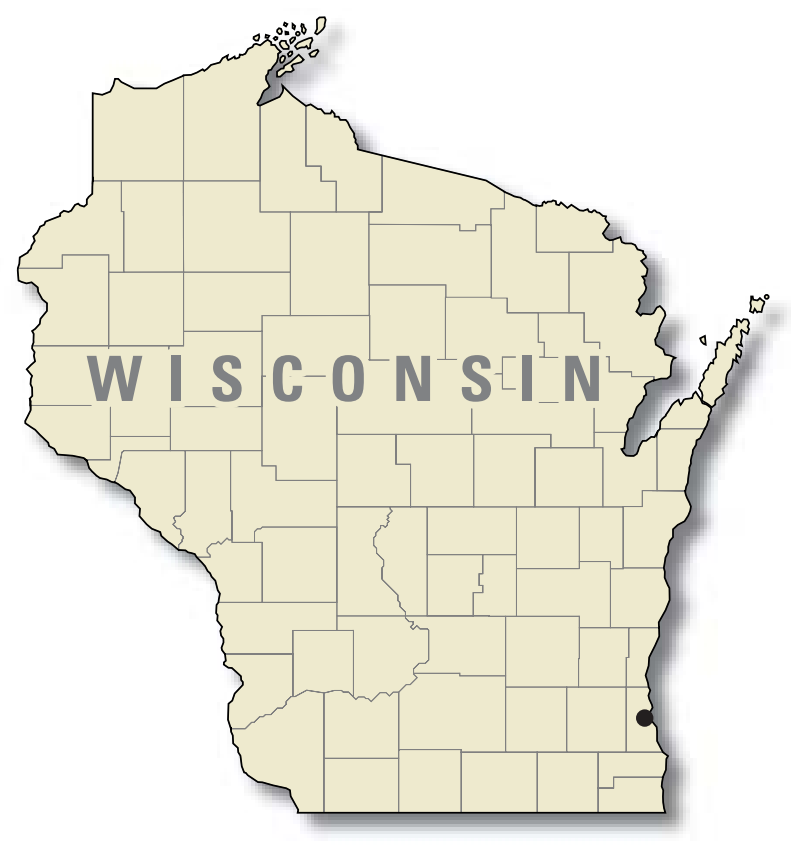

ability in freeway runoff quality, (4) characterize pollutant loading in freeway runoff, and (5) determine the practical application of the treatment devices (for example, installation, operation, and maintenance costs).

\section{APPROACH}

Discharge and event mean concentration (EMC) data will be collected at the BMP inlets and outlets for 15 consecutive large (more than 0.15 inches of precipitation) runoff events. These samples will be analyzed for total phosphorus, suspended and dissolved solids, zinc, copper, and chloride. Other samples from small (less than 0.15 inches of precipitation) events occurring between the larger events will be analyzed only for suspended solids. The data will be used to calculate individual event water-quality loads entering and exiting the BMPs. The calculated loads will be used to determine the removal efficiencies of the two treatment systems for the test period and to determine if there are any efficiency patterns related to event size. 


\section{PROGRESS (July 2001 to June 2002)}

The project proposal has been completed and monitoring equipment has been installed. Treatment systems have been installed.

\section{PLANS (July 2002 to June 2003)}

It is expected that sampling will be initiated in May 2002 and should be concluded by October 2002. This schedule depends on timely delivery and setup of the treatment devices. A data report will be written describing the BMPs, the monitoring system, and a summary of the data collected.

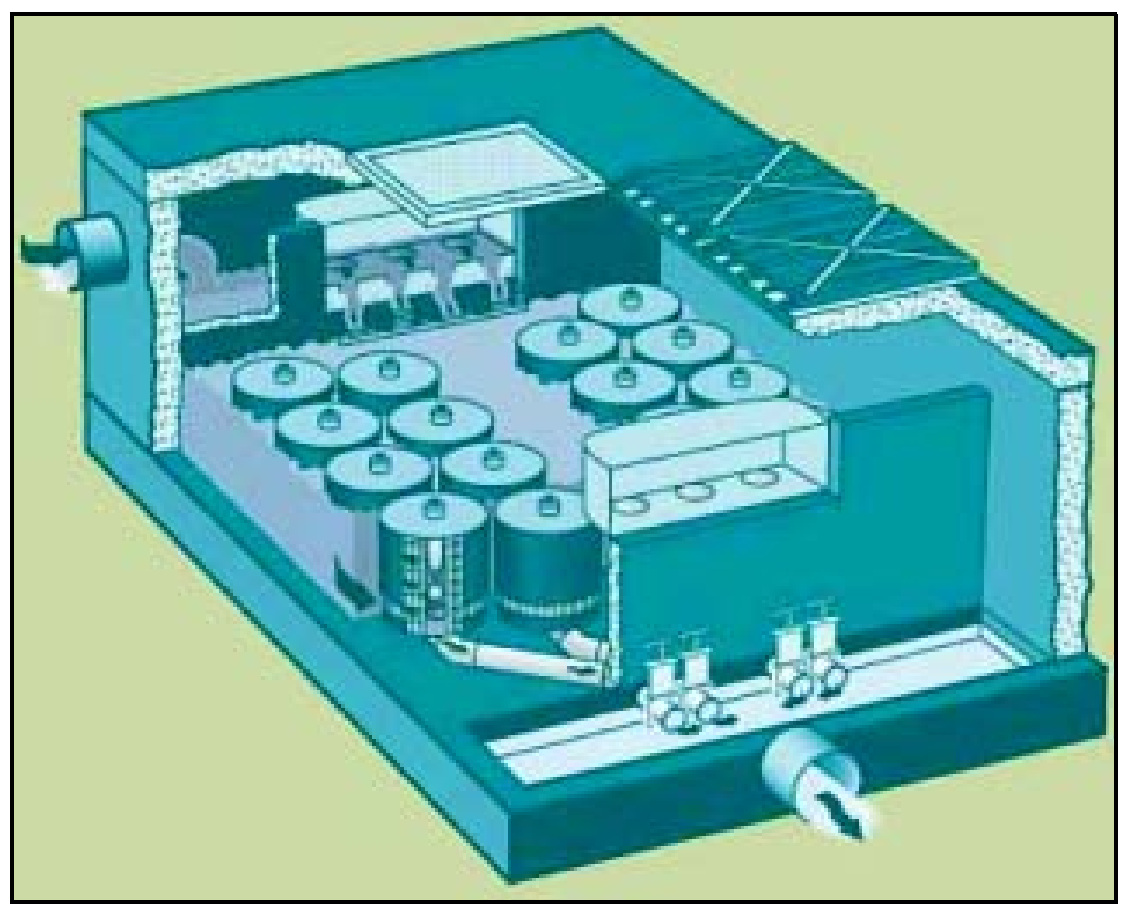

Stormfilter ${ }^{\mathrm{TM}}$ by Stormwater Management Inc.

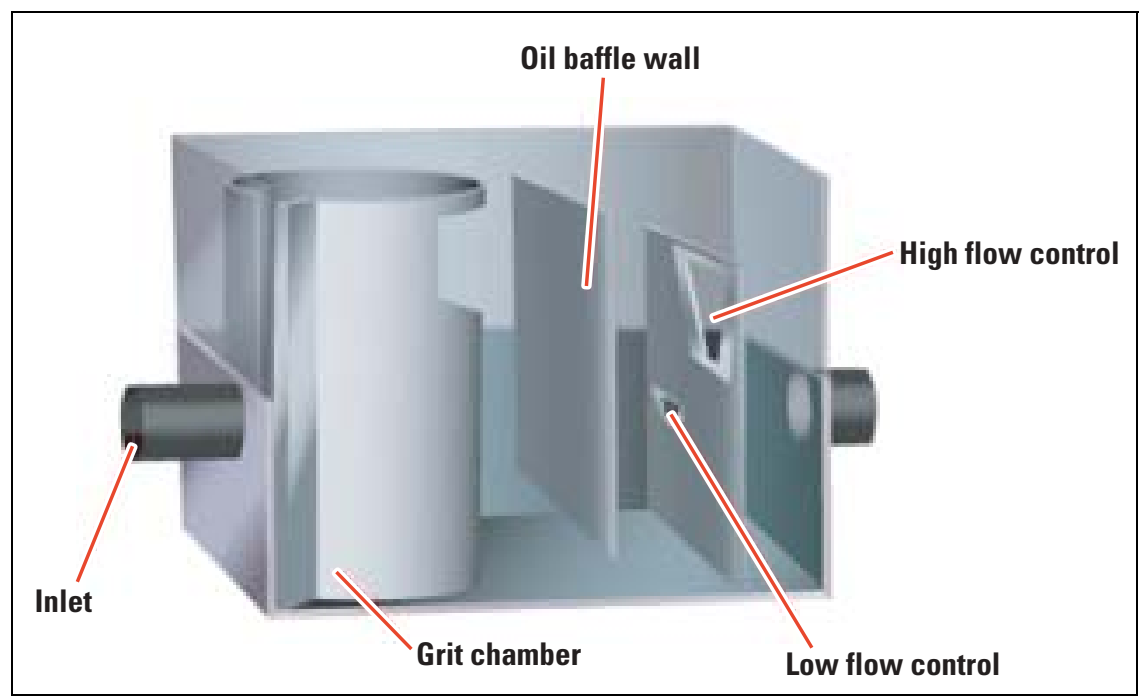

Vortechs ${ }^{\mathrm{TM}}$ System by Vortechnics 


\section{VERIFICATION OF A PRESSURIZED STORMWATER FILTRATION SYSTEM AT ST. MARY'S HOSPITAL}

\begin{tabular}{|l|}
\hline COOPERATORS: \\
Wisconsin Department of Natural \\
Resources; \\
National Science Foundation \\
PROJECT CHIEFS: \\
Judy A. Horwatich \\
Steven R. Corsi \\
LOCATION: \\
Green Bay \\
PROJECT NUMBER: \\
WI 17208 \\
PERIOD OF PROJECT: \\
September 2000-Continuing \\
\hline
\end{tabular}

\section{PROBLEM}

Urban stormwater is degrading Wisconsin waters. Cost-effective treatment technologies are needed to reduce adverse impacts that urban stormwater runoff can have on surface-water quality. A variety of advanced technologies have emerged in recent years that can help communities achieve compliance with new regulations. The EPA's Environmental Technology Verification (ETV) Program established a cooperative agreement with the National Standards Foundation (NSF) International to verify the treatment capabilities of the proprietary treatment devices.

The Wisconsin Department of Natural Resources and the USGS will conduct a study of a pressurized stormwater filtration system as an ETV program. The system has been installed at St. Mary's Hospital in Green Bay and is being used to treat runoff from its parking lot and rooftops. Stormwater is captured and pumped through a two-phase filter system and discharged into a city storm sewer. Backflush water is discharged into a sanitary sewer.

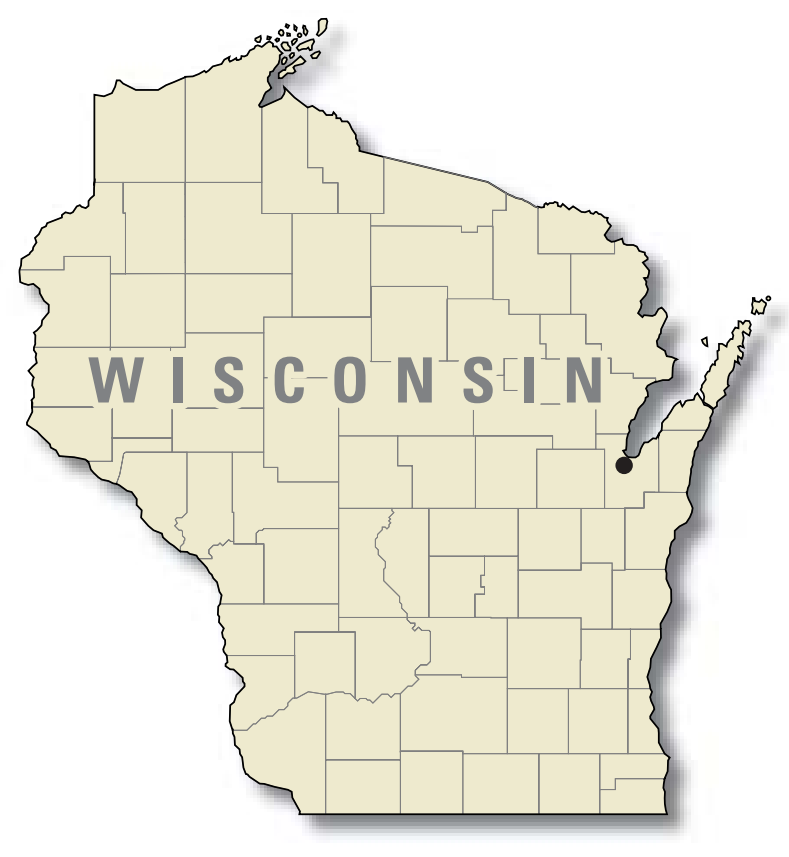

\section{OBJECTIVE}

The project objective is to determine the efficiency of the pressurized filtration system in extracting sediment, nutrients, and zinc from stormwater runoff.

\section{APPROACH}

To accomplish the above objective, the following approach will be used: (1) install flow-monitoring and water-quality sampling equipment at the inflow, outflow, and bypass of the system, (2) continuously monitor rainfall and flow, and collect water-quality samples for 15 runoff events in 2001, (3) analyze samples for sediment, total and dissolved phosphorus, Kjeldahl N, $\mathrm{NO}_{2}-\mathrm{NO}_{3} \mathrm{~N}$, and zinc, (4) compute loads for inflow, filtered outflow, and bypass for the above constituents, (5) compute a mass balance on flow and water-quality loads for all events, and (6) publish a technical report on the results of the study. 
PROGRESS (September 2000 to June 2001)

All equipment has been installed and is operational. Several test samples have been collected.

\section{PLANS (July 2001 to June 2002)}

Plans are to: (1) monitor 9 additional consecutive storms that have more than 0.2 inches of rain, (2) compute the discharge record and water-quality loads for the three monitoring locations, (3) complete a mass balance summary for the monitored storms, and (4) publish the results of the study.

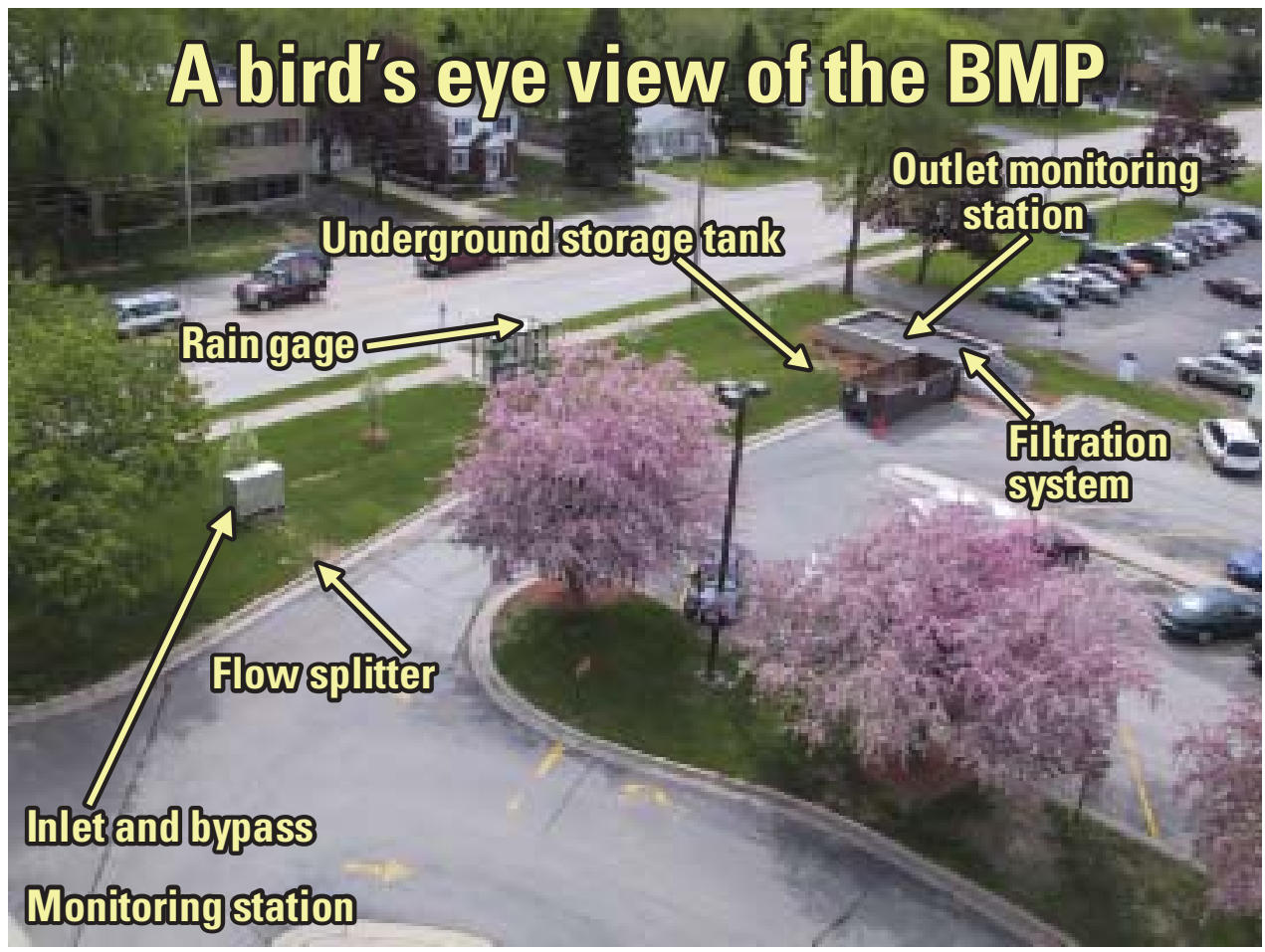

Overview of monitoring and filter systems. 


\section{THRESHOLDS OF TOXICITY IN URBAN STREAMS}

\author{
COOPERATOR: \\ Wisconsin Department of Natural \\ Resources

\section{PROJECT CHIEF:} \\ Steven R. Corsi

\section{LOCATION:} \\ Statewide

\section{PROJECT NUMBER:} \\ WI 17216

\section{PERIOD OF PROJECT:} \\ July 2001 to September 2002
}

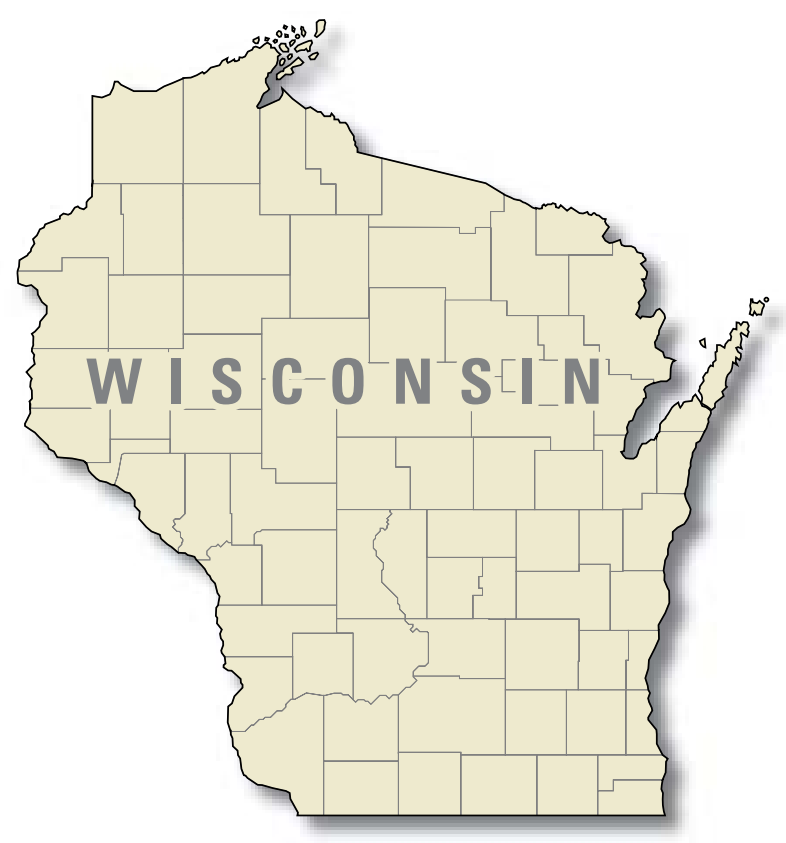

to those presently used in urban areas. One question that needs to be addressed is whether there is a threshold level of watershed imperviousness below which regulation of toxicants in stormwater runoff is not needed? Another question that needs to be answered is at what field concentration of potential toxicants do we see adverse effects in stream-dwelling organisms? This will permit regulatory effort to be more effectively focused on problem areas and problem chemicals.

The Wisconsin Department of Natural Resources would use this information to identify areas where regulation of toxicants in runoff is necessary to protect, enhance, or restore aquatic communities. Municipalities will need this information to most economically and effectively comply with these impending regulations.

\section{OBJECTIVE}

The purpose of this study is to examine the relation of watershed imperviousness in urban river systems to measures of toxicity in aquatic organisms. Specific objectives include: (1) determine the chronic toxicity of urban river systems to $P$. promelas in 30-day tests using 
in-situ caged fish tests, and (2) support an effect by University of Wisconsin-Stevens Point (UWSP) and University of Wisconsin- Milwaukee (UWM) to study acute and chronic toxicity of urban river systems on several organisms as well as short-term effects on reproductive success of $P$. promelas, effects on reflex/predator avoidance behaviors in $P$. promelas offspring, and effects on preference-avoidance behavior and habitat selection in $P$. promelas adults.

\section{APPROACH}

The USGS portion of this project will include the caged-fish study and support of the UWSP-UWM monitoring efforts by providing an adequate shelter for testing, water level for determination of stream status, and coordination of shelter transport between sites.

In-stream fathead minnow exposures will involve the following details: (1) in-stream fathead minnow exposures will consist of a number of test chambers (3 or 4 at a time) and one control chamber placed at different locations longitudinally on the stream, (2) tests will ideally coincide with other toxicity monitoring by UWSP-UWM, (3) chambers consist of 4 cartridges with 5 adult minnows ( 3 months old) per cartridge, (4) the ideal stream will flow from 0.0 percent urban impact to a high urban impact and changes will be placed at several places longitudinally along the stream. The control chamber will be defined as the chamber at the location with 0.0 percent urban impact. Exact placement of chambers will be dependent on the depth and flow conditions of each individual stream, (5) if suitable conditions do not exist for placement of chambers in some portions of the stream, nearby streams with appropriate urban impact will be considered as well, and (6) site visits will be made by UWSP personnel each day to check on the condition of the minnows. During each site visit, dissolved oxygen, conductivity, and water temperature will be recorded in the stream and in each cartridge.

Support of the UWSP-UWM effort will include the following: (1) the monitoring shelter will consist of a rented construction trailer that will be used by UWSP, UWM, and paid for from the USGS budget, (2) the site will be located near a stream gage or other source to provide electrical connections, and (3) the trailer rental agency will transport the monitoring station between sites.

\section{PROGRESS (July 2001 to June 2002)}

The sites have been selected and procurement at the shelter is ongoing.

\section{PLANS (July 2002 to June 2003)}

Four to five sites will be monitored during the 2002 summer and another four to five sites during the 2003 summer. 


\section{CALIBRATION OF THE SOURCE LOADING AND MANAGEMENT MODEL (SLAMM)}

\begin{tabular}{|l|}
\hline COOPERATOR: \\
Wisconsin Department of Natural \\
Resources \\
PROJECT CHIEF: \\
Judy A. Horwatich \\
LOCATION: \\
Statewide \\
PROJECT NUMBER: \\
WI 17219 \\
PERIOD OF PROJECT: \\
July 2001-Continuing \\
\hline
\end{tabular}

\section{PROBLEM}

Wisconsin municipalities are using urban runoff models to help them prepare stormwater management plans. Planners and engineers use the models to identify the most important sources of pollutants and quantify the benefits of different management alternatives. The Source Loading and Management Model (SLAMM) is one of the models recommended for stormwater planning by the WDNR.

All watershed models should be calibrated before they are applied. Large errors in flow and pollutant concentrations can result if the model is not adjusted as much as possible to the places it will be used. In most cases the municipalities will not have the resources to collect the necessary flow and pollutant concentration data. Fortunately, enough stormwater data has been collected to adjust SLAMM for use by municipalities in Wisconsin.

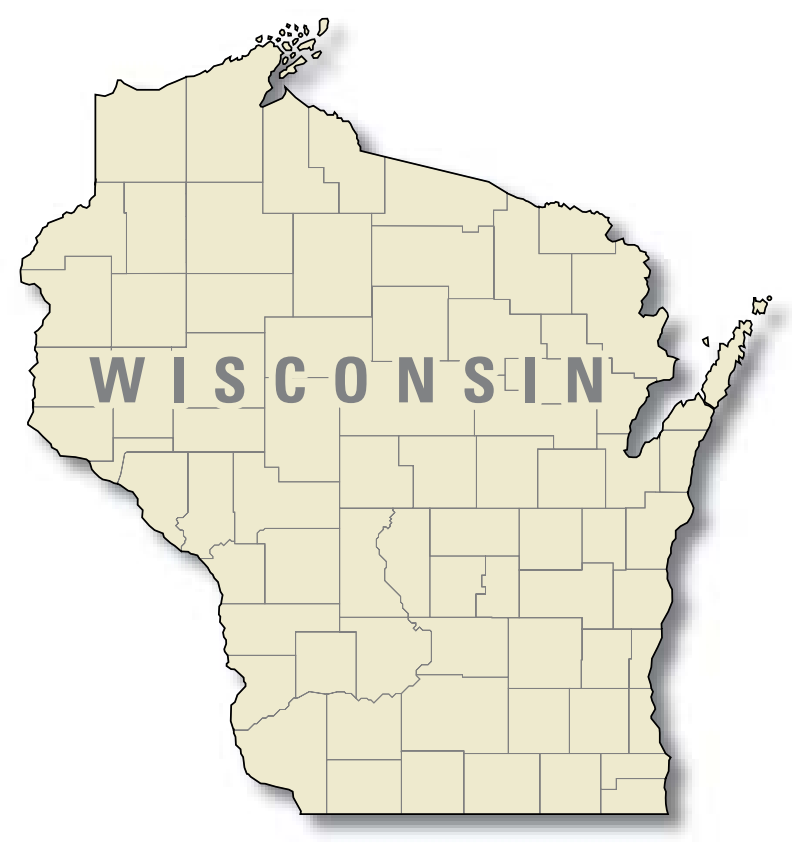

\section{OBJECTIVE}

The objective of the project is to calibrate and verify the SLAMM model with the stormwater flow and pollutant concentration data available from urban studies conducted in Wisconsin.

\section{APPROACH}

Flow and pollutant concentrations are available from eight stormwater projects conducted by the Wisconsin USGS. Source-area concentrations were collected for four of the projects. The USGS collected flow and concentration data at the end of the pipe for all the projects. Land use and development characteristics, such as percent-connected imperviousness, were determined for each study area. All the above information is needed to calibrate and verify SLAMM. 
There are three steps to calibrate SLAMM. First, the predicted runoff volumes should be adjusted to match the values observed at the end of the pipe. After the appropriate rainfall file is created, the runoff volumes are predicted for each rainfall event. To determine what adjustments are needed to the model's rsv (runoff coefficients) file, plots are made to describe the bias and variance between the predicted and observed values. Runoff coefficients in the rsv files are increased or decreased to minimize the bias and variance. Multiple model runs must be made until the rsv values produce the best results possible for all eight sites.

Second, the predicted particle solids loads should be adjusted to match, as much as possible, the observed particle solids loads at all eight sites. The two steps in adjusting the predicted particle solids loads are:

(1) entering the average source area particle solids concentrations into the model's particulate solids concentration files, and (2) modifying std (street delivery) file until the predicted and observed end of the pipe particulate loads are reasonably close for all eight sites.

All remaining pollutants are calibrated in the last step. Normalized particulate concentrations are determined for phosphorus, zinc, copper, and PAHs. The geometric mean for each source is entered into the model's ppd file. Then the geometric mean of the dissolved concentrations for each source area is entered into the ppd file. Large differences in predicted and measured loads could justify some adjustment to the measured values in the ppd files. Again the files would have to be adjusted so the predicted values match as best as possible for all eight study sites.

All the files created by the calibration will be placed on the USGS web page. A link will be made from the WDNR web page to the USGS web page.

\section{PROGRESS (July 2001 to June 2002)}

Flow, pollutant concentration, and land use data has been compiled. Calibration of the runoff volume is also completed. Plots have been prepared describing the bias and variance between the predicted and measured values. Calibration of the particulate solids loads is almost completed. Files are available on the USGS web page.

\section{PLANS (July 2002 to June 2003)}

Calibration work will be completed for the particulate solids, phosphorus, zinc, copper, and PAHs. At the end of this year we plan to compile the data from three more stormwater studies and verify SLAMM. We will calibrate the rsv file for pervious areas based on a lawn runoff study. An Open-File Report will be published explaining calibration of the model.

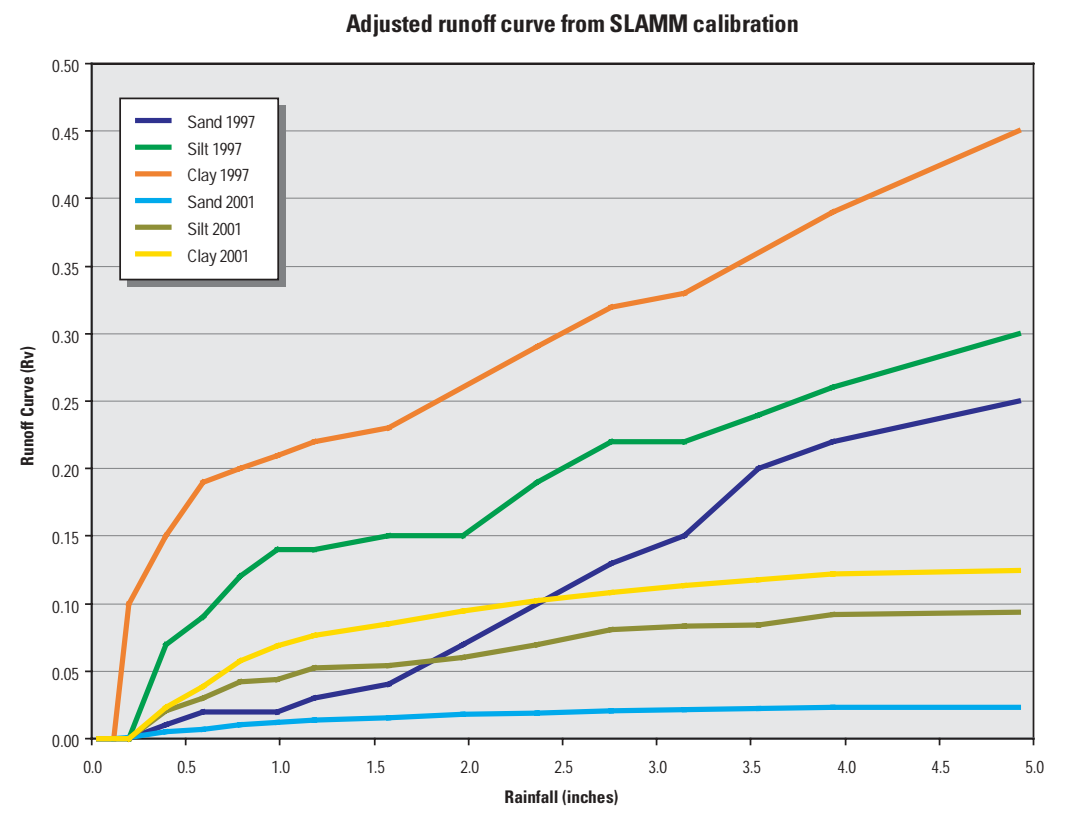

Comparing SLAMM curve number before and after calibrations. 


\section{EVALUATING IMPROVED STREET SWEEPING FOR ENHANCING WATER QUALITY IN HIGHWAY RUNOFF IN MILWAUKEE}

\section{COOPERATOR: \\ Wisconsin Department of \\ Transportation}

PROJECT CHIEF:

Robert J. Waschbusch

\section{LOCATION:}

Milwaukee County

PROJECT NUMBER:

WI 17231

PERIOD OF PROJECT:

October 1998 to September 2002

\section{PROBLEM}

The Wisconsin Department of Transportation (WDOT) is required to control the quality of runoff from roadways under their control as part of the National Pollutant Discharge Elimination System (NPDES). One way to control roadway runoff quality is to use street sweeping to remove pollutants before they are entrained in runoff. This option may be more cost effective than structural BMPs since WDOT already conducts street sweeping and would only need to increase the frequency of sweeping and use an improved sweeper.

\section{OBJECTIVES}

The primary objective of the investigation is to determine if water-quality benefits are realized by improved street sweeping and, if so, to what degree. Secondary objectives are to: (1) develop accumulation curves for solids deposited on freeways in the greater Milwaukee area, (2) use solids accumulation curves and water-quality data to calibrate the SIMPTM model, (3) characterize the variability in freeway runoff quality;

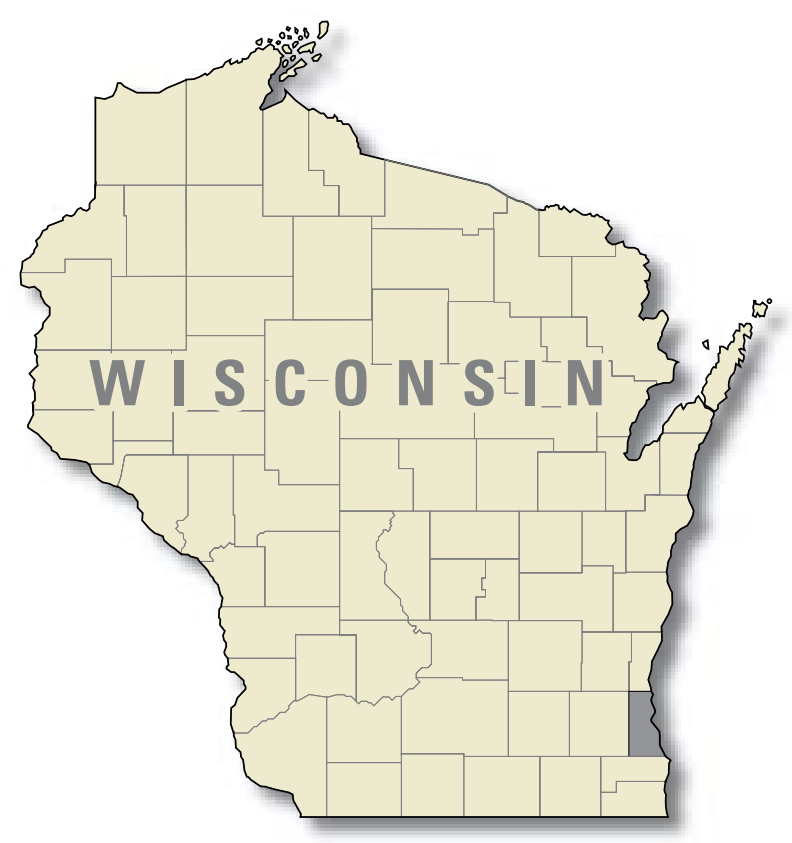

and (4) characterize pollutant loading with and without the street-sweeping program.

\section{APPROACH}

This study used a paired-basin approach, shoulders in the test basin were swept once a week with an Envirowhirl street sweeper and the control basin was never swept. Regression relations will be determined between the test and control basins for both sweeping and nonsweeping periods. If the slope and intercept of the regression relationships are significantly different between the sweeping and non-sweeping periods, the difference will be attributed to street sweeping.

Baseline periods, where no sweeping occurs in either the test or control basin, will be used to define concentration relations for runoff events between the basins. These relations will then be compared to concentration relations found between the basins during sweeping periods. Sweeping periods will have the test basin swept at a rate of once per week and the control basin unswept. The sweeping and non-sweeping schedule was selected to provide an equal number of sweep- 
ing versus non-sweeping samples from frontal, convective and winter runoff events.

\section{PROGRESS (July 2001 to March 2002)}

Monitoring for the project was completed at the end of September 2000. Preliminary data analysis has been performed on the runoff concentration data and the results presented at the Fox-Wolf 2000 stormwater conference in Green Bay in February 2001. Data and analysis results were delivered to the WDOT for publication in a WDOT research project report. In addition, a U.S. Geological Survey Open-File Report is being prepared. The Open-File Report has gone through editorial and technical review and is currently being prepared for publication.

\section{PLANS (March 2002 to July 2003)}

U.S. Geological Survey Open-File Report will be finalized and published. The WDOT research project report will be published approximately August 1, 2002. Results of the project were presented to the WDOT Technical Oversight Committee. 


\section{EVALUATION OF THE EFFECTIVENESS OF LOW-IMPACT DEVELOPMENT PRACTICES}

\begin{tabular}{|l|}
\hline COOPERATOR: \\
Wisconsin Department of Natural \\
Resources \\
PROJECT CHIEF: \\
William R. Selbig \\
LOCATION: \\
Cross Plains \\
PROJECT NUMBER: \\
WI 17233 \\
PERIOD OF PROJECT: \\
July 1998 to September 2005 \\
\hline
\end{tabular}

\section{PROBLEM}

Farmland in Wisconsin is rapidly being converted to urban land uses. This urban development, with the associated increase in impervious area, generally impacts the water quality and increases the runoff volume that is delivered to the receiving water-body. When new site plans are proposed, many of the plans use "endof-pipe" structural Best Management Practices (BMPs) such as wet and dry detention ponds. These structural BMPs however are primarily designed to reduce the flood peak of a runoff event. They have limited water quality and quantity benefits.

Low-impact development is designed to reduce the volume and improve the quality of runoff while attempting to preserve the natural hydrology of the site. Low impact practices include the reduction of impervious surfaces and installation of infiltration devices, such as rain gardens.

\section{OBJECTIVE}

To evaluate the effectiveness of low-impact practices for reducing runoff quantity and improving runoff water quality.

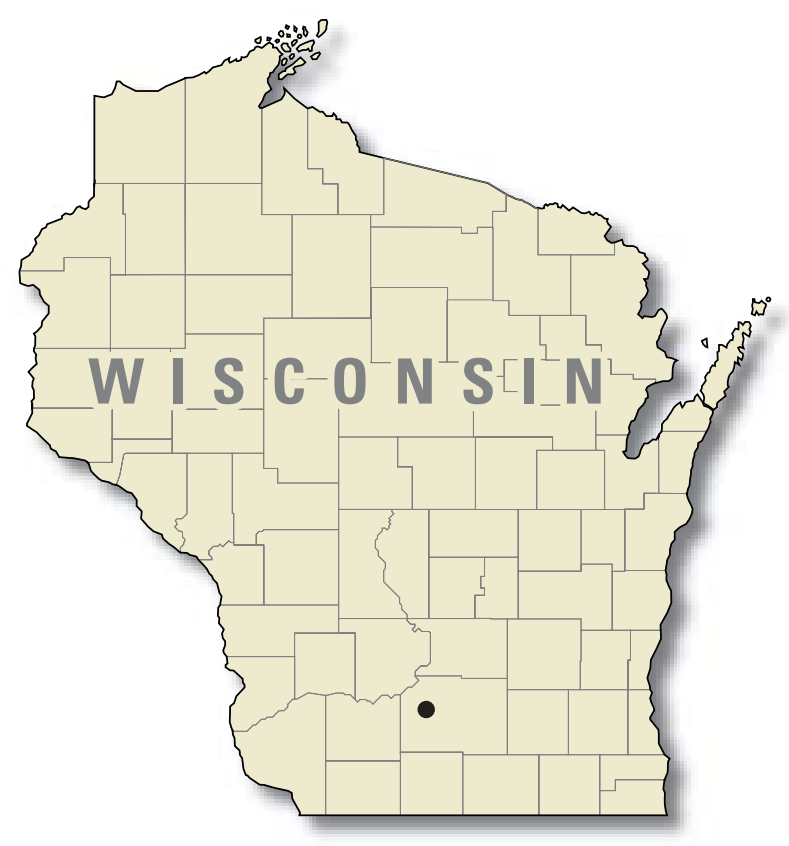

\section{APPROACH}

Test and control sites have been selected in Cross Plains, Wisconsin. The control site, which was developed from 1988 to 1991, used traditional urban design practices such as storm sewers, curbs and gutters, and a wet detention basin. The second site began development in May 1999 and is implementing low impact development practices. Both sites are finger valleys that are approximately a quarter mile apart.

Equipment at both sites are maintained to continuously monitor water level, precipitation, and water temperature and are housed in a gaging station that has phone telemetry and electrical power. An automatic water-quality sampler at each site is taking flow proportional samples from runoff producing storm events. Water-quality samples for the majority of the runoff events will be analyzed for total and suspended solids, and total and dissolved phosphorus. Periodically, samples from each site will be processed for particle size distribution and selected total and dissolved metals.

Comparisons will be made between the BMPs based on unit-area runoff and unit-area loads. Furthermore, the data collected during the 7-year period will 
document the changes in water quality and quantity during the construction cycle (from platting to site closeout).

\section{PROGRESS (July 2001 to June 2002)}

Continued monitoring and sampling at both sites. Additional equipment was installed at three detention pond inlets and the detention pond outlet to measure runoff velocity and discharge. These sites are also equipped to capture water-quality samples. Soil reflectometers and thermocouples were installed near the center of the infiltration basin to continuously measure soil moisture levels at various depths. Also, soil cores were taken at various locations within the infiltration basin to better understand the performance of the practice.

\section{PLANS (July 2002 to June 2003)}

Continue to monitor and sample both sites. Additional infiltration tests will be performed not only on the infiltration practice but also on outlying pervious surfaces to comprehensively understand expected infiltration rates and track any decreases over time. Two flumes will be installed to measure volume of water that enters the infiltration basin from the north end. A piezometer will be installed near the detention pond invert to measure fluctuations in storage previous to and during runoff events.

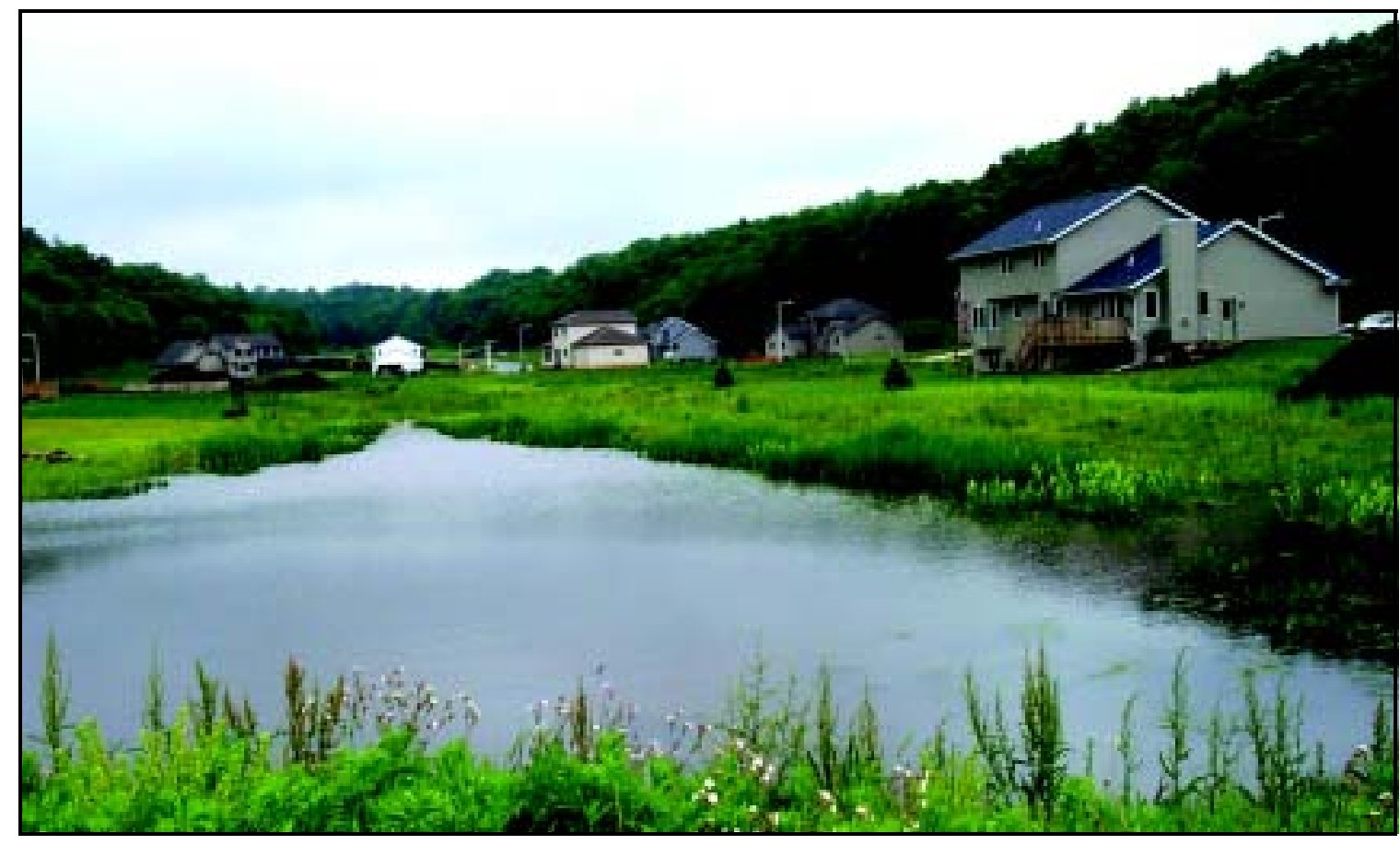

A detention pond designed for stormwater treatment in the Cedar Hills residential development, Cross Plains, Wisconsin. 


\section{IMPACTS OF RESIDENTIAL CONSTRUCTION ON STREAMWATER QUALITY}

\author{
COOPERATOR: \\ Dane County Land Conservation \\ Department

\section{PROJECT CHIEF:} \\ William R. Selbig

\section{LOCATION:} \\ Cross Plains

\section{PROJECT NUMBER:} \\ WI 17235 \\ PERIOD OF PROJECT: \\ April 1999 to September 2003
}

\section{PROBLEM}

Population in Dane County, Wisconsin, is growing at a fast pace. Farmland is being taken out of crop production and being replaced with urban land uses. During this urbanization, large tracts of land are being disturbed to create new subdivisions for residential housing. This disturbance can have a negative impact on in-stream water quality and quantity such as sedimentation and higher temperature. Quantification of these changes needs to be documented to reduce future in-stream impacts.

\section{OBJECTIVE}

The main objective of this project is to determine the "in-stream" impacts of residential urbanization on a small stream in Cross Plains, Wisconsin. Additional objectives include: (1) comparing the sediment load estimated by the Universal Soil Loss Equation (USLE) and the Revised Universal Soil Loss Equation (RUSLE)

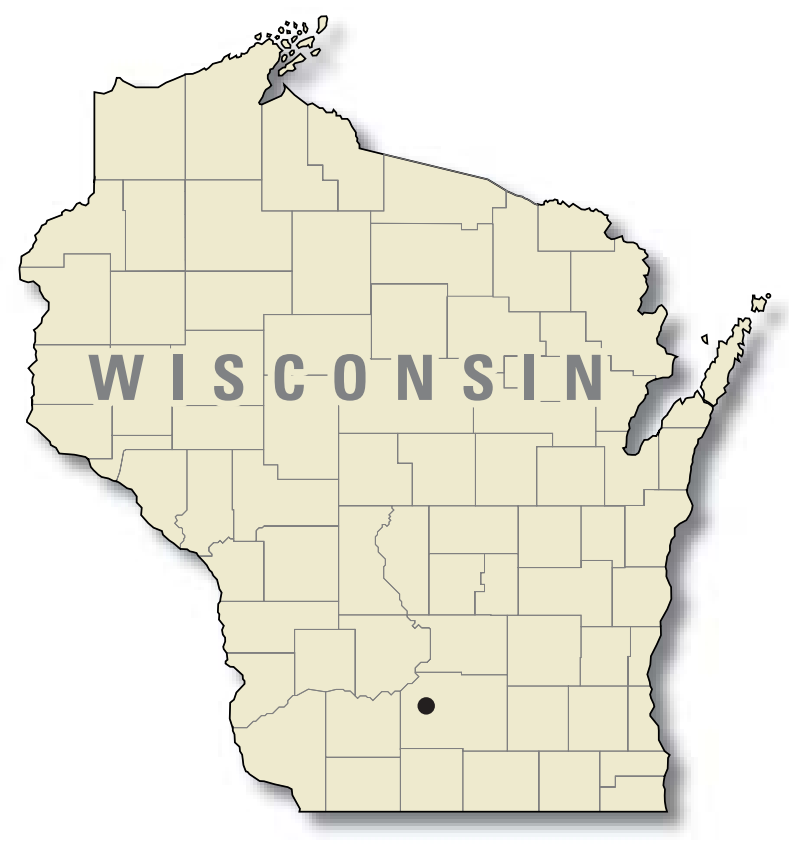

to monitored data, and (2) determining the changes in hydrology of the site by quantifying variation in peak flows as related to changes in drainage basin surface characteristics caused by the construction activities.

\section{APPROACH}

Discharge, and associated solids concentrations and loads will be measured both upstream and downstream of a 72-acre site that will be converted from agricultural to residential land use. Water-quantity, waterquality, and land-use data will be collected at a site located immediately upstream of the residential development and at an existing USGS gaging station (Brewery Creek at Cross Plains, 05406470) located immediately downstream of the development. Monitoring will be done prior to construction, during construction, and after construction. Water-quality analyses include total suspended solids, total solids, and particlesize distribution. Before and after event mean concentrations from the upstream and downstream sites will be statistically compared. 


\section{PROGRESS (July 2001 to June 2002)}

Runoff from several summer storm events and winter snowmelt events were sampled for water quality during the year as the development enters its active construction phase. An additional component was added to the study that examines the potential changes in stream geomorphology that may be a result of activities from nearby development.

\section{PLANS (July 2002 to June 2003)}

Continue monitoring and photo documentation during the active construction phase of the project. Data will be compiled and analyzed in the spring of 2003.

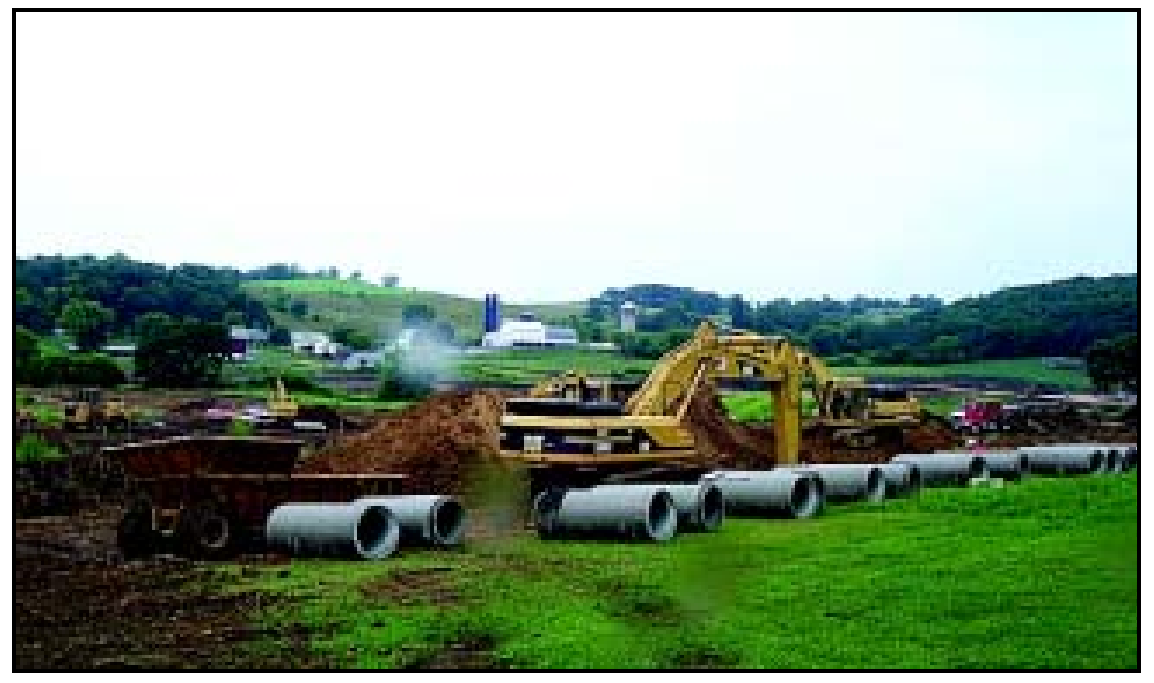

Early phases of residential construction activity. 


\section{EVALUATION OF STREET SWEEPING AS A WATER-QUALITY MANAGEMENT TOOL IN RESIDENTIAL BASINS IN MADISON}

\author{
COOPERATOR: \\ Wisconsin Department of Natural \\ Resources

\section{PROJECT CHIEF:} \\ William R. Selbig

\section{LOCATION:} \\ Dane County \\ PROJECT NUMBER: \\ WI 17237

\section{PERIOD OF PROJECT:} \\ May 2001 to September 2005
}

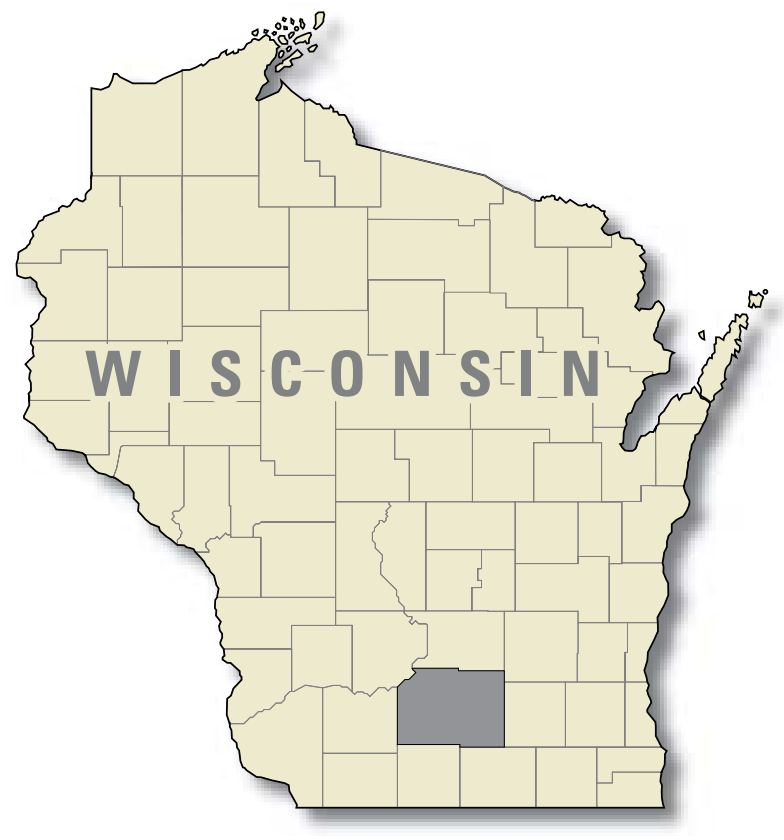

water-quality sampling results from these basins and the street dirt load data will be used to estimate the benefits that may be achieved using other street sweeping programs.

Secondary objectives are: (1) characterize street dirt loadings with and without the street sweeping program from residential streets, and (2) characterize the water quality in street runoff from residential watersheds.

\section{APPROACH}

This study will use a paired basins approach, meaning that data will be collected from four basins and then compared to each other. One basin will be the "control" basin and will have minimal sweeping. The other three basins (the "test" basins), will have different sweeping regimens implemented. Two basins will utilize two different street sweepers provided by Elgin Inc. and will be swept once per week. The remaining basins will be swept on the same schedule as other areas of Madison, approximately one time per month, and will be completed using existing equipment. Data from the test basins will be compared to data from the control basin. 
The USGS will collect vacuum samples once a week from four study basins for the duration of the study. These samples will be collected using equipment and methods similar to that described in Pitt (1979) and Waschbusch and others (1999). During sweeping periods, samples will be collected immediately before street sweeping occurs and immediately after. Street dirt data will be used to determine the pick-up efficiency of the street sweepers and the rate of dirt buildup on and wash off from the streets. The USGS will dry, sieve, and weigh the vacuum samples. The samples will be sieved into particle size fractions ranging from $<63 \mu \mathrm{m}$. to $>2,000 \mu \mathrm{m}$ in an effort to further characterize street dirt. The sieved dirt data will be used to see if there is a difference in the collection efficiency between new Elgin, Inc., sweepers and sweepers currently used by the City.

In addition to the street dirt sampling, the control basin and the basins utilizing Elgin street sweepers will have water-quality samples collected and compared. The three basins will be equipped with dataloggers, flow measurement devices or structures, phones, modems, ISCO samplers, and raingages. AC power will be necessary for battery chargers, refrigerated samplers, heating tapes on sampler intakes, and area-velocity meters.
Sweeping periods will have the test basins swept at a rate of once per week and the control basin unswept except at the beginning of an equilibration period. The City of Madison will be responsible for getting the streets swept on schedule. On days when it is raining or snowing, the street sweeping will be delayed for a day or two until the streets are dry. The sweeping schedule has been selected to provide an equal number of sweeping versus non-sweeping samples from spring, summer, and fall runoff events.

\section{PROGRESS (July 2001 to June 2002)}

Four residential basins were selected in southwest Madison. The control and two test basins were outfitted with water quantity and quality monitoring equipment at the outfall. Several runoff samples were collected and analyzed throughout the year. In addition to water-quality samples, vacuum samples were collected weekly at all four basins to characterize street dirt loadings during a non-sweeping year.

\section{PLANS (July 2002 to June 2003)}

Continue to monitor water quantity and quality at the control and test basins. Vacuum samples will be collected weekly at each basin beginning in April and will continue until late fall.

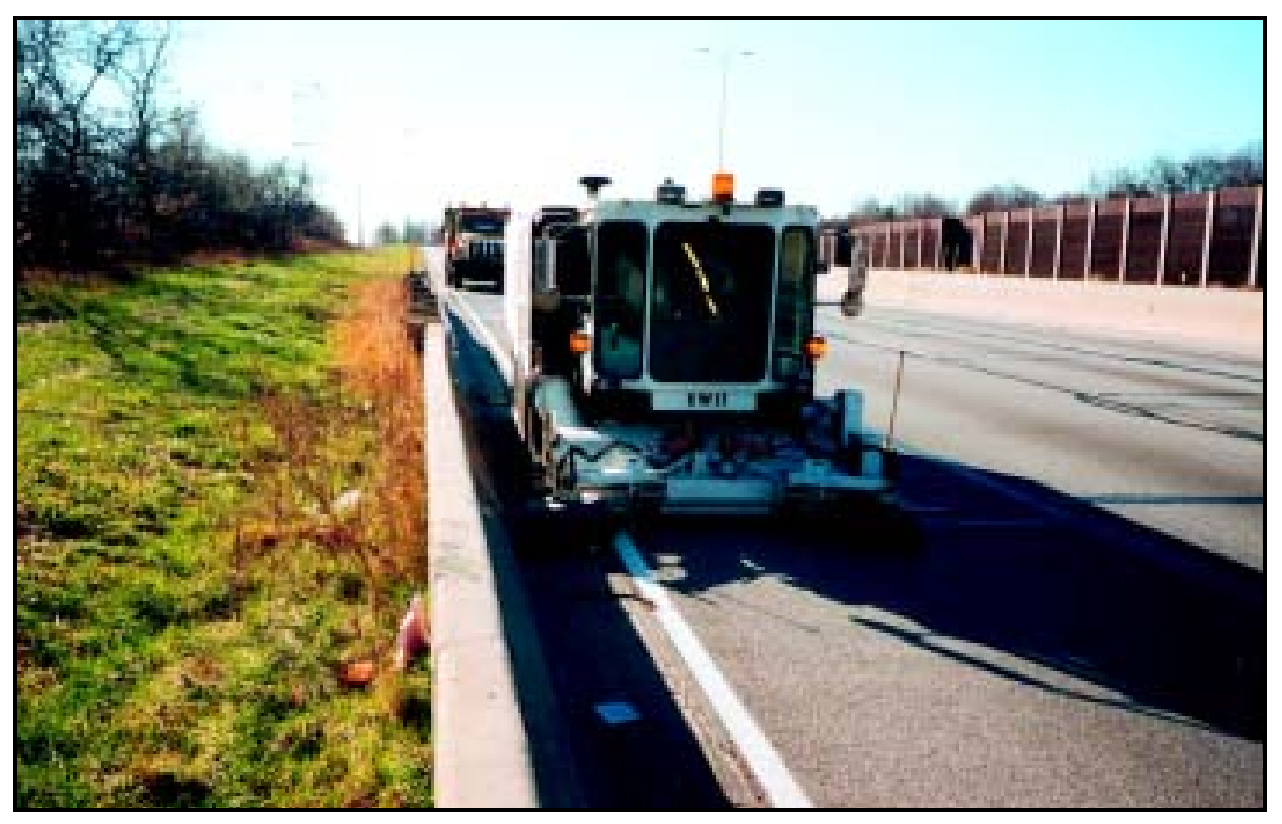

Highway street sweeping in Milwaukee, Wisconsin. 


\section{EDUCATIONAL BMP EVALUATION PROGRAM FOR TWO BASINS IN THE CITY OF MILWAUKEE}

\section{COOPERATOR:}

City of Milwaukee Public Works

Department

\section{PROJECT CHIEF:}

Peter E. Hughes

\section{LOCATION:}

City of Milwaukee

\section{PROJECT NUMBER:}

WI 17241

\section{PERIOD OF PROJECT:}

December 2001 to June 2003

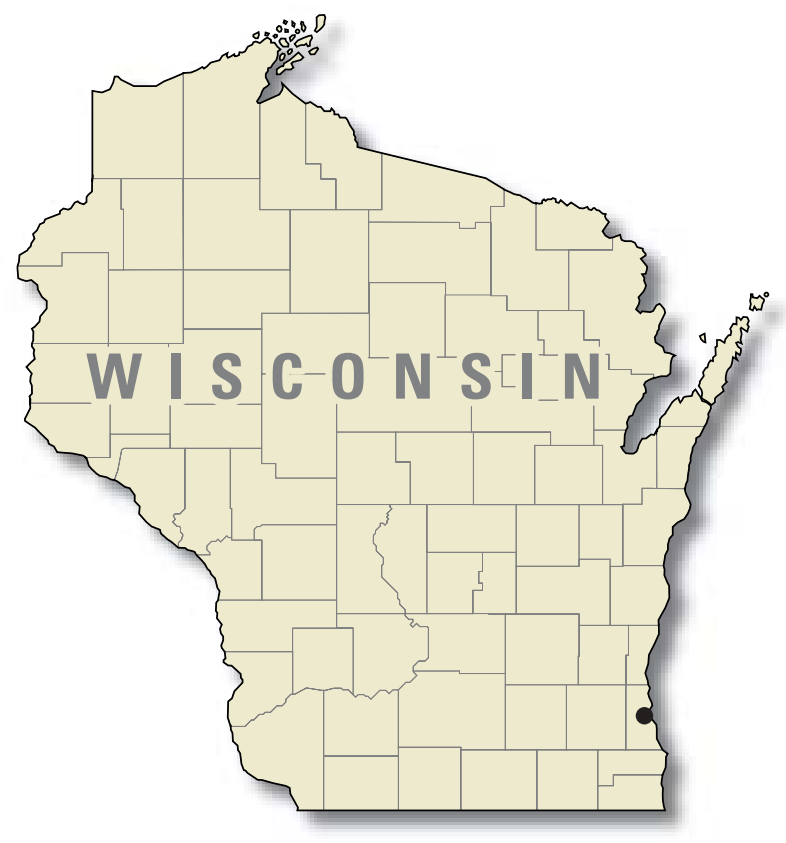

Street, to include a velocity sensor and a data-logger. The data-loggers will be programmed to activate waterquality samplers to collect a flow-proportional sample for analyses solids, nutrients, and selected organic constituents. Data will be transmitted to computers at both the USGS and the City and will be used to compute stormwater and baseline water quality loads. There will be a total of 30 event samples collected at each site and 15 base flow samples collected at the Lyons Creek site.

\section{PROGRESS (December 2001 to June 2002)}

The additional monitoring equipment has been procured and installed and sampling of baseline and storm events has begun. Data is being entered into the USGS Watstore system and the USGS is working with the City to maintain and operate the two sites.

\section{PLANS (July 2002 to June 2003)}

Complete collection of the storm and baseflow samples. Analyze the water-quality data and compute the loads for the two sites. Work with the City to summarize the data for presentation to the Wisconsin Department of Natural Resources. A data report will be prepared which will summarize the storm event loads, flow and rainfall data collected for this project. upgrade two automated sampling sites, one on Lyons Creek and one for a storm sewer at 18th and Ramsey 


\section{MONITORING AND EVALUATION OF THE IMPACTS OF AIRCRAFT AND RUNWAY DEICERS ON THE KINNICKINNIC RIVER SURFACE-WATER RESOURCES}

\section{COOPERATOR: \\ County of Milwaukee \\ PROJECT CHIEF:}

Steven R. Corsi

\section{LOCATION:}

Milwaukee

PROJECT NUMBER:

WI 20400

\section{PERIOD OF PROJECT:}

November 1996-Continuing

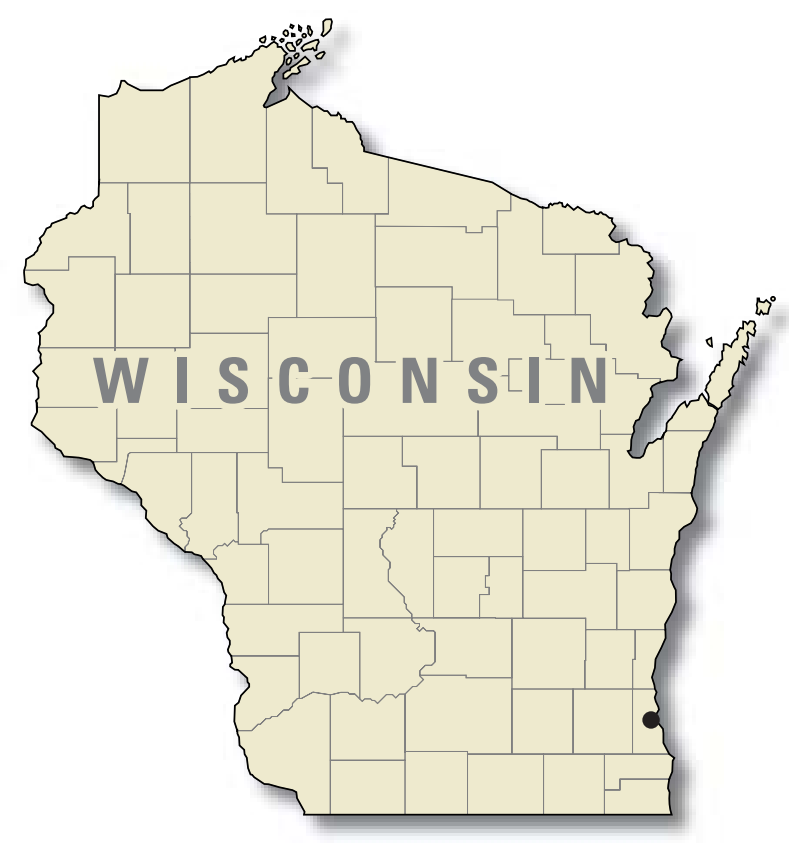

ducted before and after implementation of deicer management, and (2) determine changes in water quality and toxicity levels in Wilson Park Creek due to implementation of deicer management. This monitoring should quantify a suite of water-quality parameters that are of interest as stated in the WPDES permit issued to GMIA by WDNR.

\section{APPROACH}

Flow is measured and samples are collected at one site upstream from airport runoff and three sites downstream. Assessments of water quality will be made on a yearly basis. After two years of post-management monitoring, comparisons between pre- and post-management data will be made to determine if changes in water quality have occurred.

\section{PROGRESS (July 2001 to June 2002)}

An extensive runoff monitoring program has been in place since November 1996. The first two winters represent conditions before deicer management was implemented.The 1998-2001 winter represent data 
with partial deicer management. The 2000-2002 winter represents fully implemented deicer management conditions. Nine sites were monitored the first year, and four sites are currently being monitored. Flow, dissolved oxygen, water temperature, and rainfall are being monitored continuously. Water-quality constituents are sampled selectively during deicer application events, baseflow, and one summer rainfall event per year. Glycol, biochemical oxygen demand, selected nutrients, and selected metals analyses are being conducted. Microtox and bioassay analyses are being conducted for toxicity assessment. In situ fathead minnow assays were conducted upstream and downstream from airport runoff. Two journal articles were written summarizing the first two years of dissolved oxygen, water chemistry, and toxicity data. Snow banks within the airport have been monitored for three years to determine the quantity of deicer stored within the snowbanks.

\section{PLANS (July 2002 to June 2003)}

At least one more year of monitoring is planned during post implementation conditions. After monitoring of post-implementation runoff, statistical analyses will be conducted to determine the effectiveness of the deicer management practice. A direct comparison of pre- to post-implementation data will be done using paired-watershed and upstream-downstream analyses between sites.

Two reports have been written and were published in June 2001. Two more papers are currently being written discussing the effects of deicer additives and at least two additional reports will be published. One will discuss the results of snowbank monitoring, and the other will analyze the effectiveness of deicer management practices at GMIA.

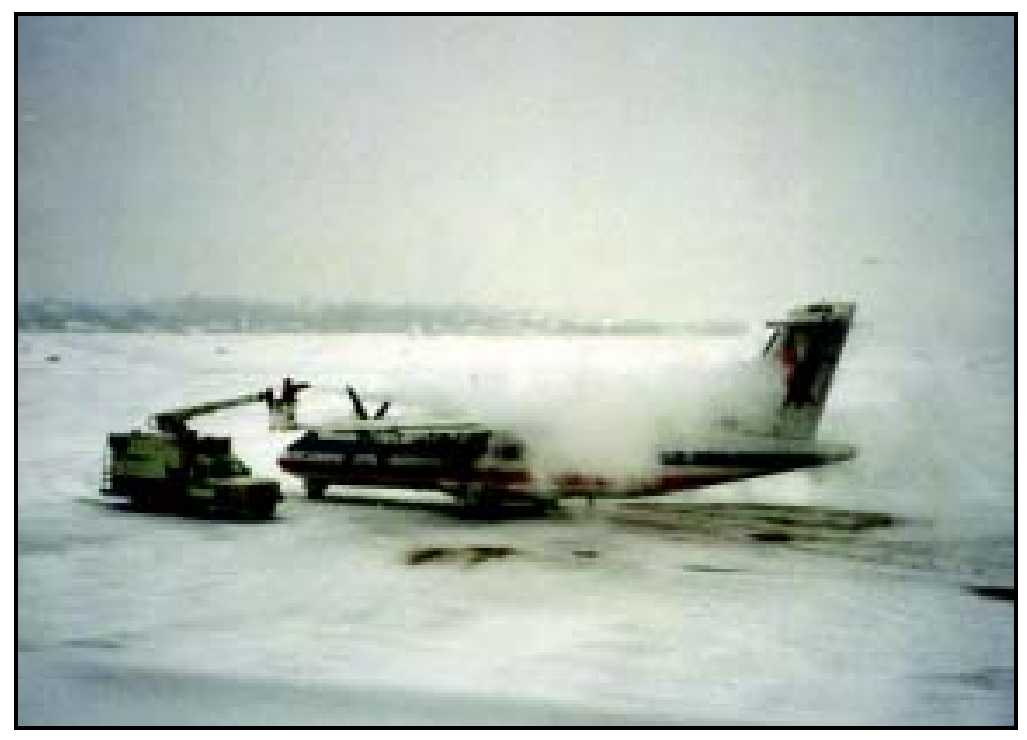

Aircraft undergoing deicing at General Mitchell International Airport, Milwaukee, Wisconsin. 


\section{SOURCES OF CRYPTOSPORIDIUM IN WATERSHEDS}

\author{
COOPERATOR: \\ Wisconsin State Laboratory of \\ Hygiene

\section{PROJECT CHIEF:} \\ Steven R. Corsi \\ Robert J. Waschbusch

\section{LOCATION:} \\ Southeast Wisconsin \\ PROJECT NUMBER: \\ WI 21600 \\ PERIOD OF PROJECT: \\ October 1999 to April 2002
}

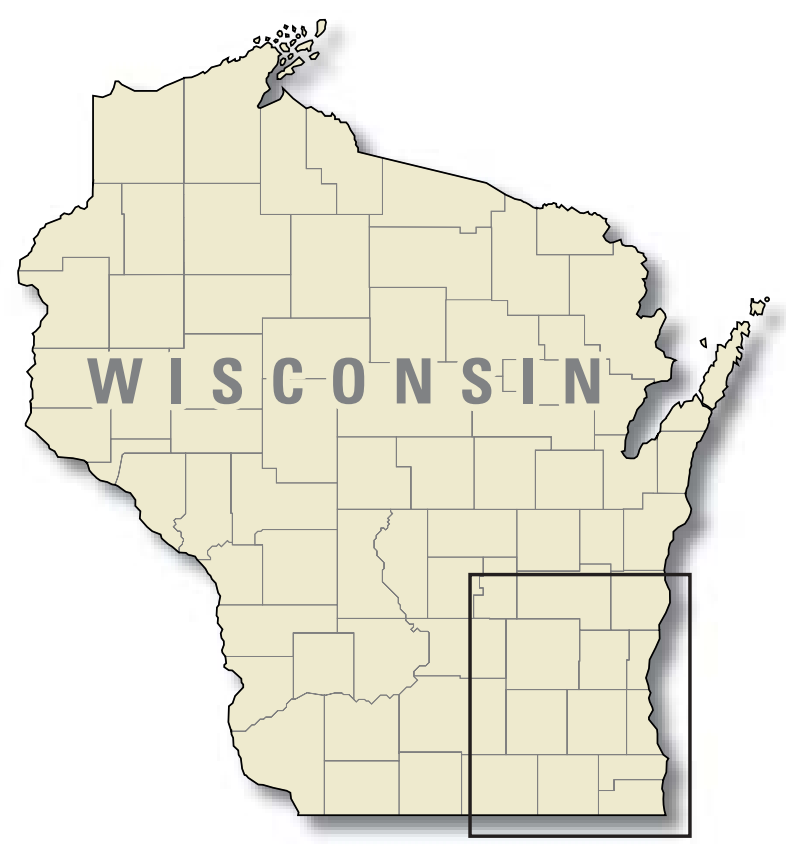

to this understanding is the ability to characterize potential sources of cryptosporidium and predict their response to hydrologic and climatologic events.

\section{OBJECTIVE}

The goals of this research study are to define the relative magnitude and contributions of cryptosporidium from major sources defined by land use and wastewater discharges on an annual basis, to characterize contributions of each source by factors such as hydrograph timing, climatic effects, and seasonal variations, and to compare and integrate the resulting data with existing data on cryptosporidium.

\section{APPROACH}

Two subwatersheds were selected for monitoring the entire project duration. One of these basins is primarily agricultural land use and the other is primarily urban land use. In addition to these two subwatersheds, three wastewater treatment plant discharges representing different treatment technologies and/or flow levels and one combined sewer overflow (CSO) were moni- 
tored for approximately six months each. Both fixed interval and weather event samples were collected from all sites. The sample results will be used to determine cryptosporidium magnitude and variability. These data will be used along with flow data to calculate event and annual loads at the sites. Other data were also collected including precipitation, water temperature, dissolved oxygen, turbidity, conductance and also land-use data in a GIS system. The data and tools resulting from this project will enable managers to better understand and deal with the sources of cryptosporidium in their watersheds.

\section{PROGRESS (July 2000 to June 2001)}

Sampling is complete at all sites. The initial phase of data reduction is complete.

\section{PLANS (July 2001 to June 2002)}

Data analysis will be finalized and final reports will be written.

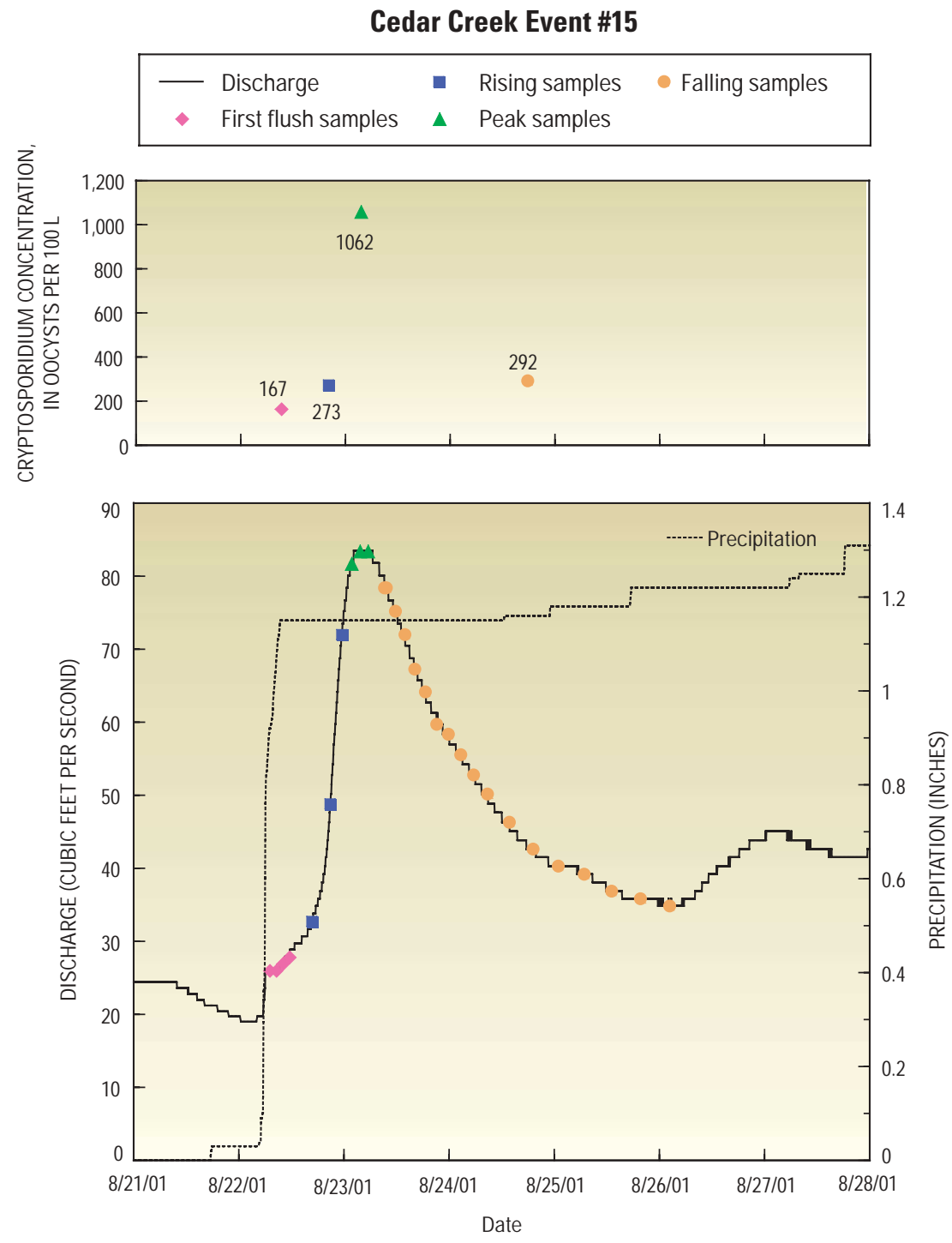

Graph showing precipitation and resultant hydrograph at the Cedar Creek monitoring site. The points on the hydrograph indicate where cryptosporidium subsamples were collected. Subsamples with the same type of points were composited into a single sample for cryptosporidium analysis, the results of which are indicated at the upper portion of the figure. 


\section{OCCURRENCE AND VARIABILITY OF PATHOGENS IN WISCONSIN'S URBAN STREAMS}

\section{COOPERATOR:}

Wisconsin Department of Natural Resources

\section{PROJECT CHIEFS:}

Robert J. Waschbusch

Steven R. Corsi

\section{LOCATIONS:}

Milwaukee area and Superior area

\section{PROJECT NUMBER:}

WI 22300

\section{PERIOD OF PROJECT:}

March 2001 to December 2003

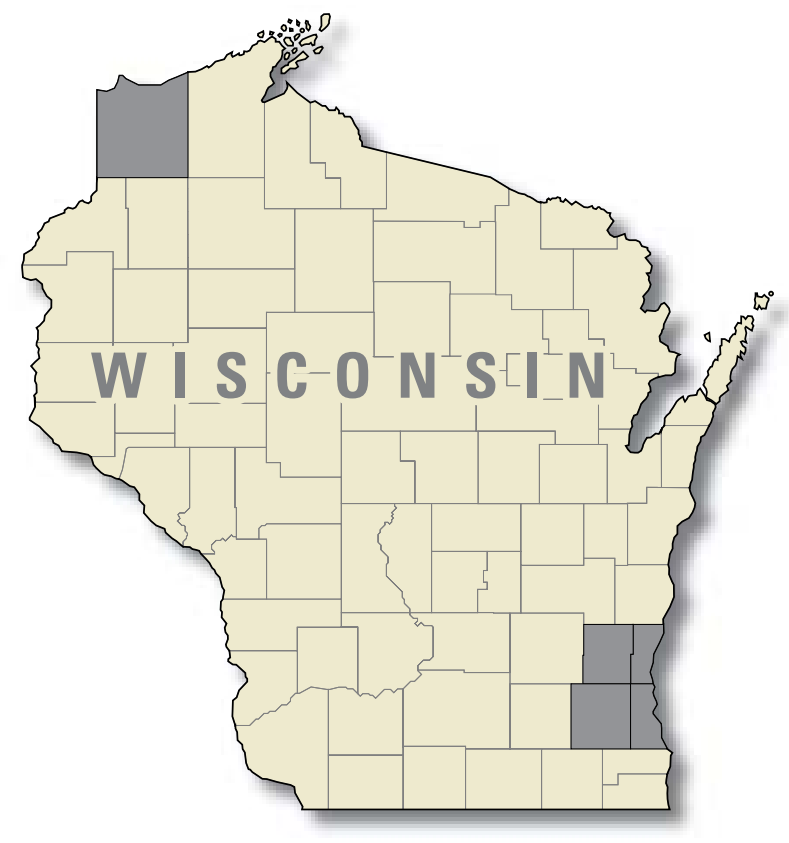

regions of the State. Though not as prevalent as SSOs on a statewide basis, combined sewers and their associated overflows (CSO) may also be important localized sources of pathogens. A third important source of pathogens is runoff water from storm sewers and diffuse inputs. Past research has shown microbial densities in stormwater runoff to be similar to those found in diluted raw sewage. Sources of these organisms include livestock, beavers, pets, and waterfowl. The documented presence of pathogenic organisms, such as Giardia, Cryptosporidium, Salmonellae, Pseudomonas aeruginosa in storm sewers with no sanitary sewer connections, suggests that diffuse or nonpoint sources of these microorganisms may be an overlooked water-quality issue.

\section{OBJECTIVE}

The overall goal of this project is to provide a greater understanding of the occurrence of pathogenic organisms in urban streams. Specific objectives include: (1) determine concentrations of pathogenic indicators and specific pathogens in urban streams of 
different sizes, land uses, and point source inputs, (2) determine ambient concentrations of total suspended solids, BOD, total phosphorus, and chloride, (3) collect 13 rounds of samples at each site- 9 event samples and 4 baseflow samples, (4) explore the resulting data in an attempt to develop relations between watershed size, major land use, hydrologic and meteorological conditions, and water-quality parameters identified above, and (5) determine sources and relative contributions of $E$. coli bacteria to urban streams by use of strain identification and typing.

\section{APPROACH}

The USGS will operate two continuous monitoring stations-one at the mouth of the Milwaukee River in Milwaukee and one further up in the Milwaukee River watershed on Cedar Creek at Grafton. The Wisconsin Department of Natural Resources (WDNR) will collect samples at numerous streams in the Milwaukee area. The focus of this study will be a synoptic survey of 12 stream sites in the Milwaukee metropolitan area and 2 in the Superior area. Milwaukee sites will be selected to spatially cover the watershed draining to the Milwaukee Harbor. All sites will be selected to represent a range of water-course size, land use (residential, indus- trial, open space), and point- source input locations (CSO, SSO, and stormwater discharges). A total of 14 stream sites will be chosen, with some streams having more than one site to examine downstream longitudinal changes. The sampling goal will be to collect a total of 13 grab samples at each site (flow composite samples at the USGS sites), 9 during periods of high flow, and 4 during base-flow conditions. Sampling will be spaced to address seasonal differences, and will occur over a period of 1-1/2 years. Recent advances in genetic strain identification will be used in conjunction with the sampling effort to attempt to identify the sources of $E$. coli. An analysis of this data will provide an assessment of the potential risks from the pathogenic presence.

\section{PROGRESS (March 2001 to June 2002)}

Sites have been operating since spring 2001, and the first six rounds of samples have been collected.

\section{PLANS (July 2002 to June 2003)}

Two more rounds of baseflow samples and five more rounds of event samples will be collected. Sampling will continue through September. Data analysis and final reporting will be conducted in the following fall and winter period. 



\section{COLLECTION OF REAL-TIME AND PATHOGEN DATA AT RECREATIONAL BEACHES IN MADISON}

\section{COOPERATOR:}

City of Madison

\section{PROJECT CHIEFS:}

Robert J. Waschbusch

Steven R. Corsi

\section{LOCATION:}

Madison

\section{PROJECT NUMBER:}

WI 22800

\section{PERIOD OF PROJECT:}

January 2002 to September 2004

\section{PROBLEM}

The City of Madison, Wisconsin contains three recreational lakes with over 20 miles of shoreline within the city limits. For over 50 years, the Madison Department of Public Health (MDPH) has conducted weekly microbiological testing of the thirteen beaches surrounding these lakes. Historically, fecal coliform and other indicator testing has been performed, with the recent addition of nonpathogenic E.coli. The MDPH has developed beach-closing criteria based on testing results, combined with physical observations of conditions at the beach site. Traditionally the decision to close a beach has been communicated via posting of signs at the beach site as well as press releases. Since 1999, the MDPH has also posted a rating system on their web page to communicate beach conditions.

Although the MDPH has developed beach-closing criteria based on microbial indicators, there is a concern that the criteria may not reflect the actual risk to swimmers since the occurrence of pathogenic microorganisms during periods of high indicator levels has never been determined. The historic records demonstrate that bacterial indicator levels may vary significantly from

one beach to another with no apparent explanation for the differences. This variation confounds the beach closing decision-making process. There is a need to gather data to bring clarity through data based decision making to this process.

\section{OBJECTIVE}

The overall objective of this project is to develop a method of estimating the likelihood of occurrence of waterborne pathogens. Project deliverable will include: (1) a systematic characterization of the correlations between traditional indicator microorganisms and origins of fecal contaminants (human vs. animal sources), (2) evaluation and implementation of a new sensitive analytical method for detecting E.coli 0157:H7 in recreational waters, (3) a data-driven decision process (model) based on actual risk of pathogen occurrence linked with indicator testing data to determine beach closing parameters, and (4) an enhanced ability to provide real-time, user friendly, state-of-the-art water quality information to the public, which will include public education regarding recreational water quality issues. 


\section{APPROACH}

Three beaches in Madison will be selected for monitoring, each on a different Madison lake. One will be located near a strormwater runoff outfall, one will be on a small shallow lake with high user counts and one will be on a large lake with low user counts. Weather monitoring, automatic water quality monitoring and sampling equipment will be installed at each beach. Several water quality and weather variables such as water temperature, precipitation, turbidity, rainfall, windspeed, and direction and wave height will be continually monitored. City of Madison beach personnel will record swimmer and waterfowl counts, and note any diaper/fecal accidents. Indicator organism and pathogen samples will be collected 3 days a week during the swimming season (approximately Memorial Day to Labor Day) for 2 years. The automatic water quality samplers will be used to collect indicator organism and pathogen samples from six events at each beach each summer. These events may be defined as rainfall runoff events, high turbidity periods, periods of high user counts, periods of high waterfowl count, wind/wave events or other types of events. Monitoring results from the first summer will likely be used to focus event-sampling efforts the second summer. The continuously monitored water quality and weather data and indicator organism results will be used to develop a probability based tool for beach closures on likelihood of pathogen occurrence.

\section{PROGRESS (July 2001 to March 2002)}

The three beaches to be monitored have been selected and much of the monitoring equipment has been purchased.

\section{PLANS (March 2002 to July 2002)}

The monitoring equipment will be installed, beach personnel will be trained in bather and waterfowl count collection methods. The monitoring program will begin in June 2002.

\section{REPORTS}

Annual progress reports will be submitted to the U.S. Environmental Protection Agency. A final report will be produced that details the study beaches, study methods, and data collected. The report will also present results of statistical analysis and the predictive model developed. 



\section{WATER, ENERGY, AND BIOGEOCHEMICAL BUDGETS}

\section{TEAM}

\section{Mission}

As part of the national WEBB program, the goal of the Northern Temperature Lakes (NTL) project is to improve understanding of processes controlling water, energy, and biogeochemical budgets and to provide information from which to better predict water, energy, and biogeochemical fluxes over spatial and temporal scales. The findings of the studies will improve the capability to assess effects of climate variations (for example, precipitation, temperature, and radiative fluxes) and human activities (for example, land-use changes, ground-water withdrawal, and chemical contamination) on hydrological, biological, and chemical systems in the northern temperate watersheds.

\section{Team Members}

John F. Walker, Research Hydrologist/Engineering David P. Krabbenhoft, Research Hydrologist/ Geochemistry

Randy J. Hunt, Research Hydrologist/Geology Paulette R. Homant, Hydrologic Technician

\section{PROJECTS}

Hydrologic and biochemical budgets in temperate lakes and their watersheds, northern Wisconsin, WI 17500

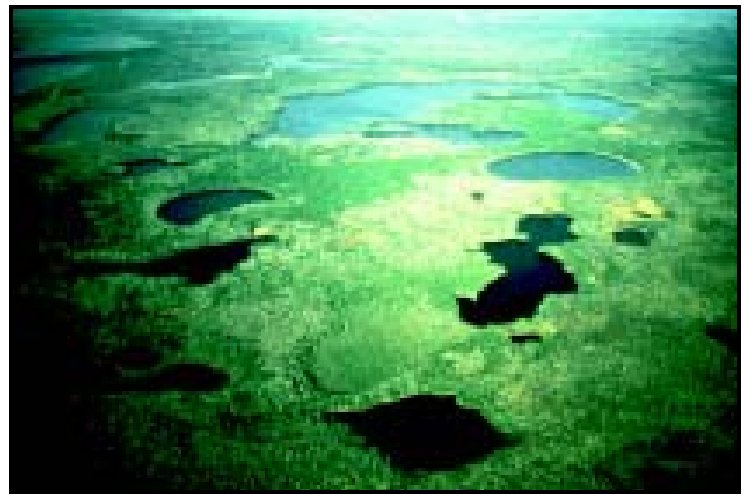

The landscape in the northern highlands lake district is dominated by a mosaic of lakes interconnected by ground water.

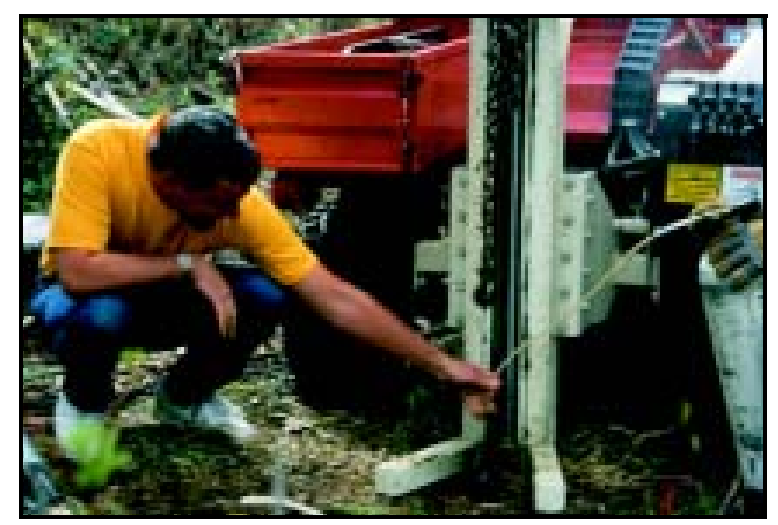

Using portable drill rigs allows the installation of monitoring wells in remote locations. 


\section{HYDROLOGIC AND BIOGEOCHEMICAL BUDGETS IN TEMPERATE LAKES AND THEIR WATERSHEDS, NORTHERN WISCONSIN}

COOPERATOR:
Global Change Hydrology
Program, U.S. Geological
Survey
PROJECT CHIEFS:
John F. Walker
David P. Krabbenhoft
Randy J. Hunt
LOCATION:
North-Central Wisconsin
PROJECT NUMBER:
WI 17500
PERIOD OF PROJECT:
October 1990-Continuing

\section{PROBLEM}

There has been expanding evidence that rates of global change are increasing. There is a need for research to identify, describe, and quantify the processes that control the Water, Energy, and Biogeochemical Budgets (WEBB) of aquatic ecosystems in order to understand and predict their responses to global change. Promotion of such research is the function of the Water Resources Discipline's WEBB program. In the northern highlands lakes district of north-central Wisconsin, five lakes and two bog lakes have been the site of long-term ecological research conducted by University of Wisconsin scientists for the past decade. These studies have provided extensive information about biological and chemical features of the lake systems, but understanding of interactions among the lakes, streams, ground-water system, and wetlands is still limited. Research is urgently needed to describe these interactions and basinwide processes that influence the character of the lakes.

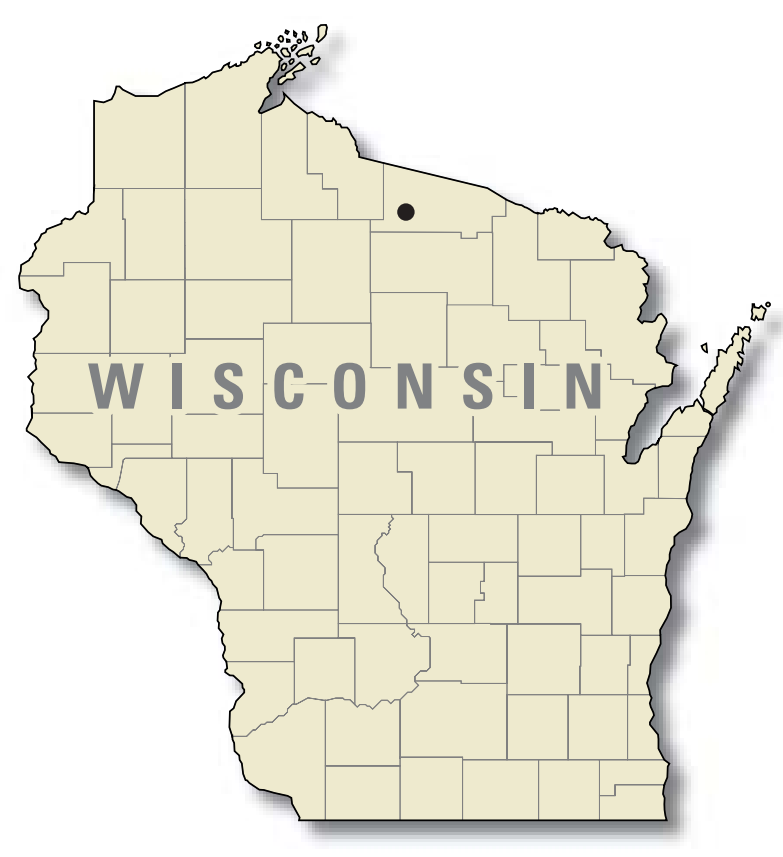

\section{OBJECTIVE}

Objectives are to: (1) describe processes controlling water and solute fluxes in northern Wisconsin lake watersheds, (2) examine interactions among those processes and their relations to climatic variables, and (3) improve the capability to predict changes in water and solute fluxes for a range of spatial and temporal scales. Fulfillment of these objectives in Wisconsin will contribute to meeting the overall objective of the federal global change program - to understand processes underlying the responses of hydrologic, biologic, and chemical systems to climate variations and human activities.

\section{APPROACH}

Selected streamflow/recharge sites on tributaries of Trout Lake are the sites for detailed research of hydrologic processes. Most of the current research effort is 
concentrated at Allequash Creek, one of four inflowing tributaries of Trout Lake. Analyses of hydrologic connections among precipitation, stream flow, and ground water are conducted at three cross sections of the Allequash Creek basin. Monitoring and sampling equipment installed at these sites include piezometer nests, lysimeters, tensiometers, precipitation collectors, and thermocouple nests. Analyses of stable isotopes $\left({ }^{13} \mathrm{C},{ }^{18} \mathrm{O},{ }^{87} \mathrm{Sr}\right.$, and $\left.{ }^{2} \mathrm{H}\right)$ are also used to determine water exchange pathways and sources of stream water. The site-specific hydrologic research is supported by data from several rain gages throughout the study area and a complete climatological station in the vicinity.

Stream- and ground-water samples, collected at each of the Trout Lake tributaries and at different points in the Allequash system, undergo analysis for nitrogen species, phosphorus, silica, organic carbon, major ions, and metals. Tributary sampling is done on a monthly basis, supplemented with more intense sampling of particular storms. Coupled with hydrologic data, the water sampling provides a basis for describing chemical budgets.

Investigation of geochemical processes that control transport of important chemical species across stream and lake sediments involves fine-scale sampling at the sediment/water interface. This is done by a variety of techniques, including membrane equilibrators, core squeezing, microprobes, and seepage meters.

\section{PROGRESS (July 2001 to June 2002)}

Ongoing data collection efforts have continued, which include collecting samples at the streams tributary to Trout Lake, operating 5 continuous-record stream gages, monitoring water levels in a network of 22 wells, and collecting samples from 36 zero-tension and 31 suction lysimeters. Four detailed monitoring sites were established and operated at existing benthic invertebrate sampling sites to support that effort. Drafts of 6 papers were completed and are in press or review. Work continued on four new research efforts, including a comparison of solute budgets across the five WEBB sites, a unified approach to watershed modeling applied to the five WEBB sites, comparison of land-use history and sediment and carbon budgets across the five sites, and an investigation of macroinvertebrate populations and energy dynamics in the Allequash Creek system.

\section{PLANS (July 2002 to June 2003)}

Basic data collection efforts will continue, as well as data collection efforts related to flow path studies, carbon dynamics in the hyporheic zone, unsaturated zone processes, and macroinvertebrate dynamics. A variety of papers currently in preparation will be published (see list of publications).

\section{REPORTS}

Pint, C.D., Hunt, R.J., and Anderson, M.P., in review, Calibrating a watershed model of a ground water dominated stream system: Allequash Creek Basin, northern Wisconsin: submitted to special watershed issue of Ground Water.

Hunt, R.J., in review, Evaluating the importance of data type and location using parameter estimation and groundwater flow models: submitted to Ground Water.

Hunt, R.J., Haitjema, H.M., Krohelski, J.T., and Feinstein, D.T., in review, Simulating lake-ground water interactions with models: MODFLOW and analytic element approaches. Director approved; invited paper for special MODFLOW 2001 issue of Ground Water.

Walker, J.F., Hunt, R.J., Bullen, T.D., Kendall, C., Krabbenhoft, D.P., and Elder, J.F., in review, Spatial and temporal variability of isotope and major ion chemistry in the Allequash Creek basin, northern Wisconsin: submitted to special watershed issue of Ground Water.

Walker, J.F., Hunt, R.J., Saad, D.A., and Plummer, L.N., in review, Using CFCs to age date ground-water recharge from lakes: submitted to Limnology and Oceanography.

Hunt, R.J., 2002, Evaluating the importance of future data collection sites using parameter estimation and analytic element groundwater flow models in Proceedings of the XIV International Conference on Computational Methods in Water Resource: Delft, Netherlands, Delft University.

Hunt, R.J., Haitjema, H.M., Krohelski, J.T., and Feinstein, D.T., 2001, Simulating groundwater-lake interactions with models: MODFLOW and analytic element approaches, p. 328-334 in MODFLOW 2001 and Other Modeling Odysseys in Proceedings of the 4th International Conference of the International Ground Water Modeling Center, Golden, CO: Colorado School of Mines.

Elder, J.F., Goddard, G.L., and Homant, P.R., Phosphorus retention and yields in hydrologically different types of wetland systems in Wisconsin (USA), in Proceedings of Societas Internationalis Limnologiae, Dublin, Ireland (in press).

Elder, J.F., Rybicki, N.B., Carter, V., and Weintraub, V., 2000, Sources and yields of dissolved carbon in Northern Wisconsin stream catchments with differing amounts of peatland: WETLANDS, v. 20, no. 1, p. 113-125.

Walker, J.F. and Bullen, T.D., 1999, Trout Lake, Wisconsin: A water, energy and biogeochemical budgets program site, U.S. Geological Survey Fact Sheet 134-99, 4 p. 
Hunt, R.J., Anderson, M.P., and Kelson, V.A., 1998, Improving a complex finite-difference ground water flow model through the use of an analytic element screening model: Ground Water, v. 36, no. 6, p. 1011-1017.

Elder, John F., Carter, Virginia, and Rybicki, N.B., 1998, Dissolved carbon mobilization in peatland/stream systems in northern Wisconsin (U.S.A.), Proceedings of V INTECOL Wetlands Symposium, Perth, Australia (in press).

Champion, G., 1998, Transient and steady-state flow of models of ground-water and lake system: Trout Lake basin, northern Wisconsin: Madison, Wis., University of Wisconsin, MS, $109 \mathrm{p}$.

Hunt, R.J., Kelson, V.A., and Anderson, M.P., 1998, Linking an analytic element code to MODFLOW-Implementation and benefits, in MODFLOW 98: Proceedings of the 3rd International Conference of the International Groundwater Modeling Center, Golden, Colorado, Colorado School of Mines, p. 497-504.

Keating, E.H., and Bahr, J.M., 1998, Using reactive solutes to constrain groundwater flow models at a site in northern Wisconsin: Water Resources Research, v. 34, no. 12, p. 3561-3571.

Keating, E.H., and Bahr, J.M., 1998, Reactive transport modeling of redox geochemistry: Approaches to chemical disequilibrium and reaction rate estimation at a site in northern Wisconsin: Water Resources Research, v. 34, no. 12 , p. 3573-3584.

Schindler, J.E., and Krabbenhoft, D.P., 1998, The hyporheic zone as a source of dissolved organic carbon and carbon gases to a temperate forested stream: Biogeochemistry, v. 43, p. 157-174.

Walker, J.F., and Krabbenhoft, D.P., 1998, Groundwater and surface-water interactions in riparian and lake-dominated systems, in McDonnell, J.J., and Kendall, C., eds., Isotope tracers in catchment hydrology: Amsterdam, The Netherlands, Elsevier, p. 467-488.

Bullen, Thomas D., Krabbenhoft, D.P., and Kendall, Carol, 1996, Kinetic and mineralogic controls on the evolution of groundwater chemistry and $87_{\mathrm{Sr}} / 86_{\mathrm{Sr}}$ in a sandy silicate aquifer, northern Wisconsin, U.S.A., Geochimica et Cosmochimica Acta, v. 60, no. 10, p. 1807-1821.

Krabbenhoft, D.P., Benoit, J.M., Babiarz, D.L., Hurley, J.P., and Andren, A.W., 1995, Mercury cycling in the Allequash Creek Watershed, northern Wisconsin, Water, Air, and Soil Pollution, v. 80, p. 425-433.

Keating, E.H., 1995, Reactive transport modelling: an application to redox geochemistry of groundwater discharging to a stream in northern Wisconsin, Ph.D. thesis, University of Wisconsin-Madison: Madison, Wisconsin, $216 \mathrm{p}$.

Krabbenhoft, D.P., Bowser, Carl J. Kendall, C., and Gat, J.R., 1994, Use of oxygen-18 and deuterium to assess the hydrology of groundwater-lake systems, in Environmental Chemistry of Lakes and Reservoirs (L.A. Baker, editor), American Chemical Society, p. 67-90.

Elder, J.F., Krabbenhoft, D.P., and Walker, J.F., 1992, Water, Energy, and Biogeochemical Budgets (WEBB) program: data availability and research at the Northern Temperate Lakes site, Wisconsin: U.S. Geological Survey Open-File Report 92-48, 15 p. 